
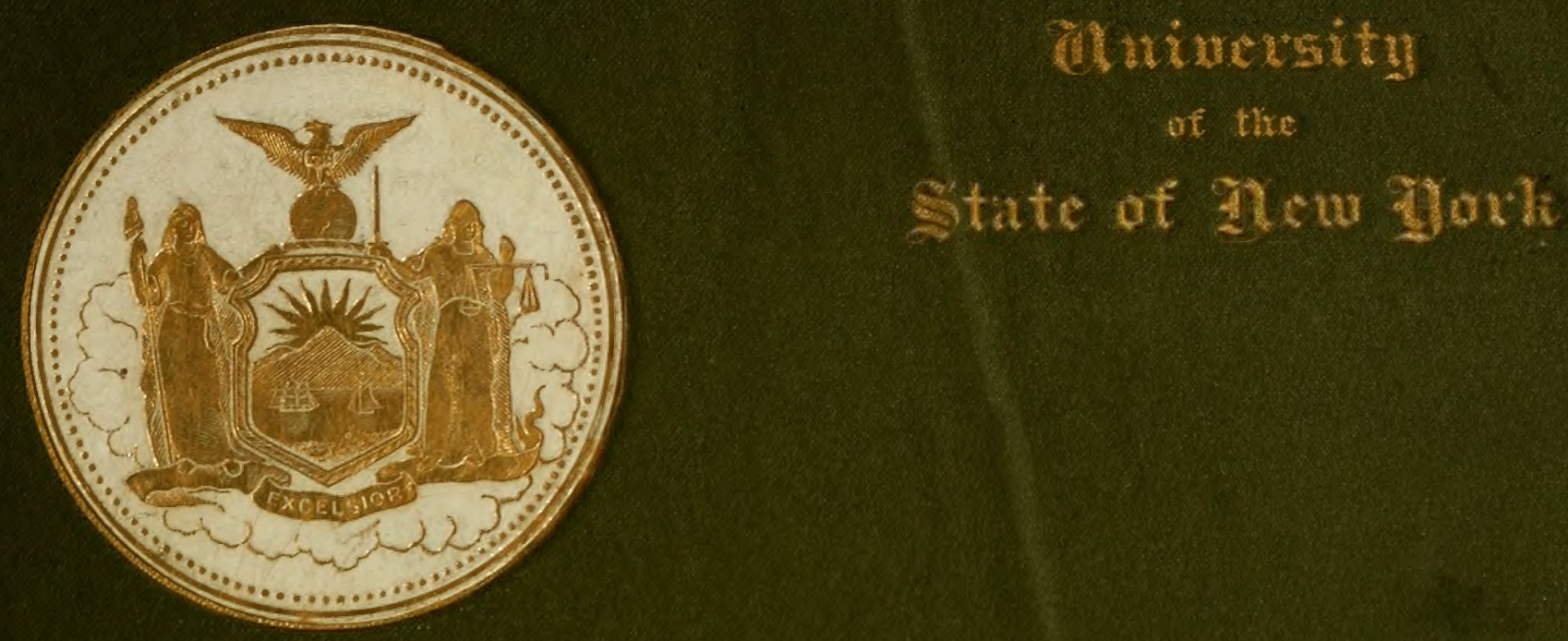

REPORT

STATE

BOTANIST

1895 


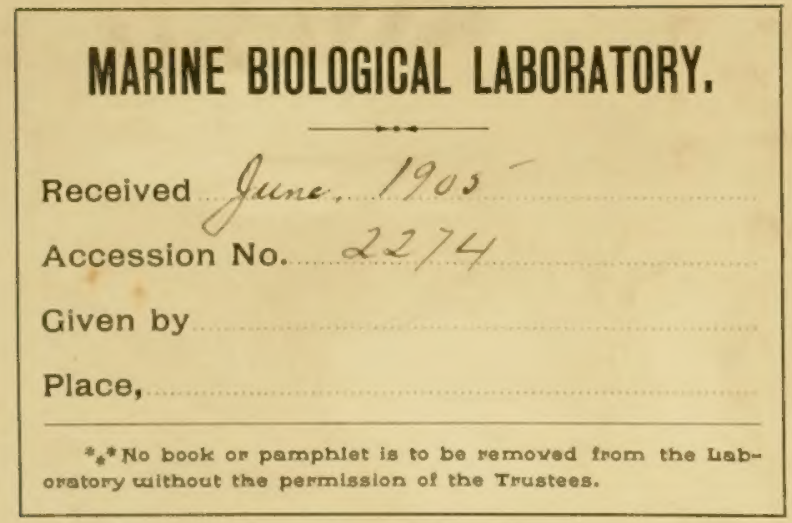





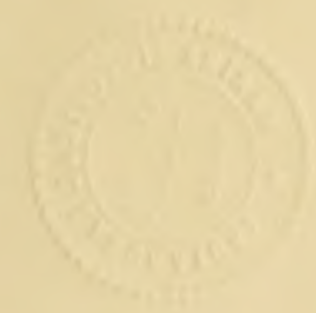




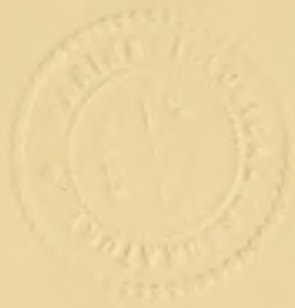



[Froy the 48th Report of the New York State Musecm]

University of the State of New York

\section{ANNUAL REPORT}

OF THE

\section{STATE BOTANIST}

Made to the Regents of the University, Pursuant to Chapter 355 of the Laws of 1883

BY CHARLES H. PECK

Second edition

ALBANY

UNIVERSITY OF THE STATE OF NEW YORK, 1897 
2719

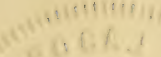

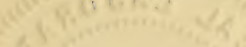

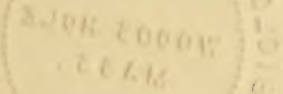




\title{
State of NEW YORK.
}

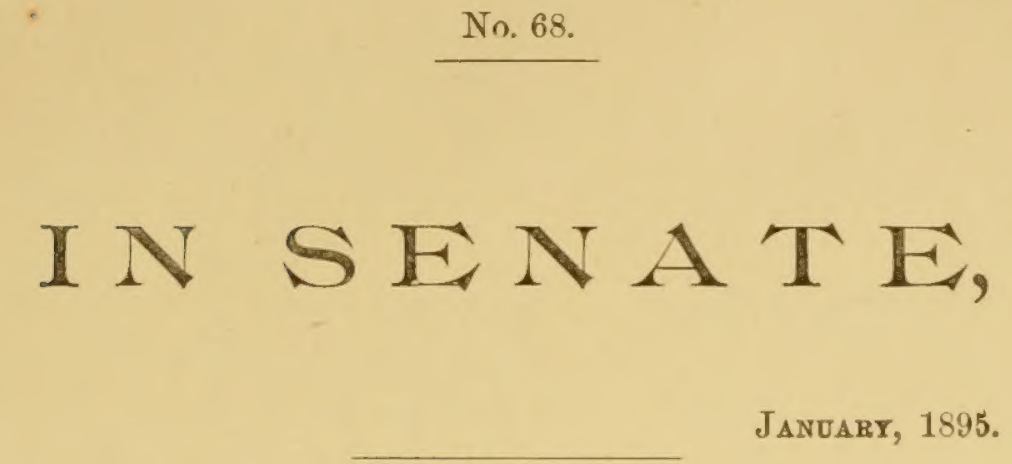

JANUARY, 1895.

\author{
A N N U A REPORT \\ OF THE \\ STATE BOTA N I S T. \\ $\left.\begin{array}{c}\text { Office of the State Botanist, } \\ \text { Albant, January, } 1895 .\end{array}\right\}$
}

To the Honorable the Regents of the University of the State of New York:

I have the honor to present to you my annual report for the year 1894.

Very respectfully.

CHARLES H. PECK. 



\section{R E POR T.}

\section{To the Honorable the Regents of the University of the State of New York:}

GeNTLEMEN.- I have the honor of communicating to you the following report, covering the time from September, 1893, to July, 1894.

Specimens of plants for the State Uerbarium bare been collected by the Botanist in the counties of Albany, Clinton, Essex, Oneida, Rensselaer, Suffolk, Ulster and Washington.

The number of species of which specimens have been added to the Herbarium is 115 , of which 24 were not previously represented therein. The species described as new aro 10. A list of added species is marked $A$.

Correspondents to the number of 11 have contributed specimens. Most of these specimens represent extra-limital species, but lire species new to the State are represented by them and four new to science. $A$ list of the contributors and of their contributions is marked $B$.

A record of species not previously recognized as belonging to our flora, together with descriptions of new species, is marlsed C.

Notes and observations on species already recorded will be found under $D$.

The genus Carex is one of the largest, and at the same time one of the most distinct and most easily recognized, of all our plant genera. In the Flora of the State of New York, Dr. John Torrey records 91 species belonging to this genus. In 1881 the number of New York species had increased to 119. At the present time we have more than 130 species. Only 29 are recorded in tho Manual that have not been found in our State, and six of these are introduced species and yet quite limited in their range. The 
genus is a most interesting ono to botanists who have acquired even a limited knowledge of it, but many pass it by as unworthy their attention or too full of difficulties to permit of the easy identification of the species. To many beginners in the stuajy of botany these plants haro been a kind of botanical bugbear. The difficulties attending their study seem to hare been needlessly increased by defective descriptions, by a failure in some cases to detect the proper limits of species, and by throwing together and describing as ono species forms that should be kept separate. In the last edition of the Manual there are many instances of the reduction of forms which in earlier years were considered good species by our most eminent botanists, so that they now stand as mero varieties to other related forms. Such a grouping of distinct forms seems to mo to bo opposed to that clear and accurate discrimination which the study of natural science ought to cultivate, and its tendency seems to be to encourage habits of careless observation and loose generalization. Some carices, it is true, resemble each other closely, but so long as they Lave constant characteristic differences, eren though these may bo slight, it seems to me much better to recognize these differences and gire them their just value in classification. And just here appears to be one cause for the absorbing interest with which the study of these plants is inrested. The close observation and the nice discrimination requisite in distinguishing closely allied species is most gratifying to an ardent student of nature intent on fincling ber hidden trutbs and solving her most intricate problems. And it is no mean accomplishment to be ablo to recognize accurately the charactors that require the separation of closely related species of this genus.

One species not recognized in the Manual has recently been detected by Dr. Ilowe, others that have hitherto been regarded as mere rarieties are, $I$ am confident, worthy of specific value, and still other forms that have not been recorded have occurred. Inlluenced by theso facts, and having in view the large number of species that belong to our flora, it has seemed desirable to mo to bring togrether in one report the revised descriptions of all our Now York species and rarieties of the grenus Carex.

'This will facilitate the study of the carices of our Stato and givo to New York botunists an additional incentivo to tho study 
of these interesting plants. I deem myself fortunate in having enlisted the interest and the aid of Dr. E. C. Howe in this work. Dr. Howe has long made a special study of the carices and his thorough knowledge of our species eminently qualifies him to speak and write about them with authority. He has prepared the monograph of our species which is here submitted and marked E.

In consequence of unexpected delay and difficulty in issuing the descriptions and illustrations of our ediolo and poisonous mushrooms in a separate publication, as was at first contemplated, it has been thought best to include tbem with other matter in the present report. The edition will be somewhat limited and may not be suflicient to supply the demand unless the issue of extra copies shall be authorized, but it will be better than a longer delay, and is apparently the best that can be done at present. T'his part of the Report is marlied $I^{3}$.

The specimens of fungi that were talien from the Herbarium and placed on exhibition at the World's Fair in Chicago last year have been returned. None were lost, but owing to dampness a few were injured by mold. They are yet in the boxes in which they were returned, not having been remored because of the possibility that the New York State exhibits might bo required for a permanent exhibit at home.

Respectfully submitted.

CHARLES II. PECK.

Albant, July 1, $18 y 4$. 
(A.)

\section{ADDITIONS TO THE HERBARIUM.}

Nero to the Ilerbarium.

Aster longifolius Lam.

Stachys palustris $L$.

Carex littoralis Schw.

Inocybe subtomentosa $\mathrm{Pl}$.

Cortinarius rimosus $P k$.

Gomphidius nigricans $P k$.

Hydnum scabripes $P k$.

Radulum molare $\mathrm{Fr}$.

Pyrenochata collabens $P$.

Vermiculare Hepatica $P k$.

V. Schonoprasi Auers.

Spharopsis ulmicola $E$. \& $E$.
Diplodia subtectoides $P h$. Septoria centauericola Brun. S. Divaricatie $E \cdot \mathbb{E} E$. Tolyposporium bullatum Schroet. Orularia decipiens Sacc.

Cylindrosporium Padi Karst.

Cladosporium carpophilum Thum. Dendry phium nodulosum Sacc. Coniothecium Rubi $P h$.

Sphærella rubina $P k$.

Diaporthe robusta $P k$.

Cucurbitaria Comptonix $E$. \& $E$.

\section{Not Nero to the Herbarium.}

Nasturtium ofticinale $R, B r$. Hypericum perforatum $L$.

Rhus Toxicodendron $I$.

Ailanthus glandulosus Desf.

Vitis riparia $M x$.

Rosa blanda Ait.

R. humilis Marsh.

Pyrus arbutifolia $L$.

Lonicera hirsuta katon.

Spirrea salicifolia $L$.

Sium cicutrefolium Gmel.

Eupatorium perfoliatum $L$.

Solidago caosia $L$.

S. Canadensis $L$.

S. nemoralis tit.

Aster linariifolius $J$.

A. Irevis $I$.

A. ericoides $t_{\Delta}$.

A. multillorus Ait.

A. ditrusus fit.

$\Lambda$. Tralescanti $L$.

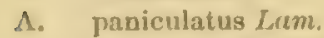

A. prenanthoides Muhl.

A. puniceus $L$.

Jidens connata Muhl.

13. cernua $L_{\text {s }}$,

Xanthium Strumarium $I$.

X. Canadenso Mill.

Mieracium aurantiacum $I$.

Verbascum Blattarin $I$.
Cuscuta Gronovii Willd.

Sonchus arvensis $L$.

S. oleraceus $L$.

Ipomaa purpurea Lam.

Callitriche verna $L$.

Potamogeton Spirillus Tuckm.

$P$.

Urtica gracilis Ait.

Amaranthus retroflexus $L$.

A. chlorostachys Willd.

Polygonella articulata Meisn.

Polygonum aviculare $L$.

P. erectum $L$.

P. Douglassii Grcene.

$P$. Hydropiper $L$.

P. lapathifolium $L$.

P. Muhlenbergii Wats .

P. Virginianum $L$.

P. dumetorum $L$.

Fraxinus Americana $I$.

Hedeoma pulegioides I'ers.

Thymus Serpyllum $L$.

Snilax herbacea $I$.

Eleocharis acicularis $R$. $B r$.

Carex raria $\mathbf{M}$ uhl.

C. prasina W'ahl.

C. arctata Boott.

C. nurea Nutt.

Panicum capillare $I$.

A grostis perennans Tuckm. 
Zizania aquatica $L$.

Mublenbergia sobolifera Trin.

M. Mexicana Trin.

II. sylvatica $T . \&$.

Arena sativa $L$.

Sporobolus vaginæflorus Vasey.

Agropyrum caninum $R$. \& $G$.

Glyceria grandis Wats.

G. nervata Trin.

Hordeum vulgare $L$.

H. distichum $L$.

Lycopodium claratum $L$.

Tricholoma terreum Schoef.

Hebeloma Colvini Pl.

Stereum sericeum Schw.

Cæoma nitens Schw.
Uromyces Desmodii Cke.

Puccinia Courolvuli (Pers).

P. graminis Pers.

Ustilago neglecta Niessl.

Urocystis Waldsteinix $\mathrm{Pl}$

Septoria Lobelix $P$ :

S. Dentaria $P k$.

S. Scrophularix Pl:

Cercospora clavata (Ger.).

Plasmopara viticola (B.\& $C$.).

Taphrina rubrobrunnea $(P h$.).

Helvella crispa $F r$.

Leotia marcida Pers.

L. circinans I'ers.

Diatrypella prominens (Howe).

(B.)

\section{CONTRIBUTORS AND THEIR CONTRIBUTIONS.}

Blephilia ciliata $R a f$.

E. J. Durand, Ithaca, N. Y.

IVm. T. Davis, New Brighton, N. Y.

Populus heterophylla $L$.

Quercus Brittoni Davis.

Pinus inops Ait.

E. W. D. Holway, Decorah, Iora.

Ravenelia Holwayi Diet.

I Puccinia Cryptanthes D.\& $I I$.

\section{J. Dearness, London, Can.}

Calamintha acinos Benth.

Armillaria mellea Vahl.

Phoma panicu'ata $E$. \& $D$.

Septoria Negundinis $E$. \& $E$.

Rabenhorstia Tiliacer $F$. \& $F$.

Hendersonia discosioides $F$. d $D$.

Strumella stagonosporioides $E$. \& $E$.

Aschersonia carpinicola $E$. \& $D$.

Cylindrosporium Chrysanthemi E.\&D.

Cercospora Lespedeza $E$. \& $D$.

C. Symphoricarpi $E^{\prime}$ \& $E^{\top}$.

C. racemosa $E$. \&,$U$.

Botrytis aftinis $E$. \& $E$.

Didymosphreria vagans $E$. \& $E$. Lasiospharia striata $E$. \& $E$.

Teichospharia subcalva $E$. of $E$. Massariovalsa caudata $E$. \& $F$.

\section{A. P. Morgan, Preston, Ohio.}

Cladotrichum polysporum $\mathrm{Cd}$.

Sporotrichum mirabile $B . \& B r$.

Synthetospora electa IIorg.

Cylindrocladium scoparium $\mathbf{M}$ org.

Ophiocera Ohiense $E$. \& $E$.

Ceratostoma setigerum $\boldsymbol{E}, \boldsymbol{\&} \boldsymbol{E}$. Eypoxylon Morgani $E$. \& $E$.

H. albocinctum $E$. \& $E$.

Hypocrea tremellicola $E$. \& $E$.

Wright Rives, Washington, D. C.

Agaricus subrufescens $P k$. 
C. V. Piper, Pulluan, Wash.

Ecidium porosum $P h$.

E. Clematidis $D C$.

E. Iydrophylli $I \%$ 。

1E. Pentastemonis Sacc.

Uromyces Erythronii (DC.).

U. Faba (lers.).

U. Glycyrrhiza (Rabh.)

Puccinia Caricis (Schum.).

I'. suareolens (Pers.).

l'. Symphoricarpi Lark:

P. congregata $E$. \& $H$.

I'. Galii Pers.

1. Scirpi DC.

P. Ralsamorlize $P k$.

P. Circew Pers.

1. Saxifraga Schlect.

1. Troxinontis Pl.

P. McClatchiana D. H Hal.

I. Zizire $F$. \& $E$.

1. mirabilissima $\mathrm{Pl}$ :

Chrssomyza Ledi $A$. \& $S$.

C. Rtsododendri (DC.)

Calyptospora Goeppertiana Kuhn.

Coleosporium Solidaginis (Sclnw.).

Melampsora Tremulæ Tul.

Dasyscypha Gaultheria $E$ \& $E$.

Rhytisma punctatum $F \cdot r$.

R. Salicis (Pers.).

Coccomyces coronatus Schum.

Phyllactinia suffulta (Reb.)

Uncinula Salicis (DC.).
Ascochyta achlyicola $E$. \& $E$.

Marsonia Veratri $E$. \& $E$.

Phyllosticta rhamnigena Sacc.

Septogloum Nuttallii IIark:

Septoria IRubi IFest.

S. Populi Desm.

S. saccharina $E \cdot \& E$

S. Enanthis $E$. \& $E$.

s. alnifolia $E$. \& $E$.

S. Megarrhize $E$. \& $E$.

S. cornicola Desm.

$\therefore \quad$ circinata $E . \& E$

S. Symphoricarpi $E$ \& $E$.

S. Brunella $\boldsymbol{E}$. d $\boldsymbol{H}$.

S. Rudbeckix E. \& Hal.

Macrosporium hybridum $E$. \& $E$.

Ramularia Philadelphi Sacc.

Cercospora rosicola Pass.

C. ribicola $E$. \& $E$.

C. sambucina $E$. \& $K$.

Cylindrosporium Filipendulse Thum.

Peronospora ribicola Schrot.

Physoderma Benyanthis De By.

Physarum papaveraceum $M c B$.

Linospora Brunella $E$. \& $E$.

Spharella arbuticola $P l$.

Spharotheca Humuli DC.

Jicrospheria $\mathrm{Alni}$ (DC.)

II. Symphoricarpi Howe.

Erysiphe Cichoreacearum $D C$.

Arthur K. Harrison, Lebanon Springs, N. Y.

Stacliys palustris $L$.

Thymus Serpyllum $L$.

Potamogeton Spirillus Tuckm.

Lycopodium claratum $L$.

Geaster limbatus $\mathrm{Fr}$.

Hymenochata rubiginosa Lev.

I. M. Underwood, Greencastle, Ind.

Gyromitra brunnea Undw.

E. C. Ilowe, M. D., Lansingburgh, N. Y.

Carex uleflexa Ilornem.

C. Limmonsii Deu.

C. L'ennsylvanica Lam.
Carex sterilis Irilld.

C. crus-corvi Shutt.

C. torta Boott.

C. L. Shear, Alcore, N. Y.

Pyrenochata collabens $I \%$.

Diplodia subtectoides 1 '

Orularia decipiens Sacc.

Diaporthe robusta $1 \%$. 
(C.)

SPECIES NOT BEFORE REPORTED.

Carex littoralis Scho.

Wet places near Islip, Long Island. May.

Volvaria Peckii Atk. nosp.

Pileus thin, conrex, glabrous, viscid, finely striate on the margin, whitish; lamellæ rather close, thin, pale flesh color; stem slightly tapering upward, glabrous, solid, whitish, with a loose, well-dereloped membranous volva at the base; spores eren, subelliptical, .0003 to $.000 t$ in. long, .0002 to .0002t broad, usually containing a singlo largo nucleus.

Pileus about 3 in. broad; stem 3 to $3.5 \mathrm{in}$. long, 3 to 4 lines thick.

Decaying wood. Ithaca. Sept. $G$. $F$. Athinson.

This species differs from $V$. speciosa in its striate margin and smaller spores. It is probably very rare and but one specimen is lnown to be in existence.

\section{Inocybe subtomentosa n. sp.}

Gregarious or subcrespitose; pileus thin, dry, convex or plane, minutely hairy-tomentose, brownish-tawny; lamella thin, close, adnate, slightly emarginate, at first whitish, then tinged with yellowish green, finally brownish-tawny; stem short, solid, slightly silky-fibrillose, colored like or a little paler than the pileus, often with a conspicuous white mycelium at the base; spores subelliptical, .0003 to .0004 in. long, .0002 to .0002t broad.

Pileus 6 to 12 lines broad; stem about 1 in. long, 1 line thick.

Gravelly soil among fallen leares Iouses Point. Sept.

This species differs from 1. tomentosa by its darker color, larger spores and the entire absence of an umbo. Its prominent features are its small size, minutely tomentose pileus and nearly uniform brownish-tawny color when mature. The lamellx are usually whitish and minutely crenulate or beaded on the edge. The species appears to belong to the section Lacerce, although the pileus scarcely shows any laceration, and eren the tomentose hairiness is hardly noticeable except on close inspection. It is distinguished from 1 . fibrillosa by its solid merely fibrillose stem and by the absence of scales on the disk of the pileus. 


\section{Cortinarius rimosus $n . s p$.}

Pileus fleshy, firm, convex or plane, glabrous, at first pale grayish violaceous, then tinged with reddish-brown, the surface cracking into appressed scales or becoming variously rimose, flesh whitish; lamelle rather broad, distant, subrentricose, emarginate, violaceous when young, becoming brownish-ochraceous with age; stem equal or slightly thickened at the base, white and silky with tho white veil, tinged with violaceous within; spores subelliptical, $.000 t$ to .0005 in. long, .0002t to .00028 broad, usually containing a single liarge nucleus.

Pileus 2 to $4 \mathrm{in}$. broad; stem 1.5 to $3 \mathrm{in}$. long, 4 to 6 lines thick.

Grassy ground in open places in thin woods. Westport. September.

This species belongs to the subgenus Dermncybe. It is a rather large and stout plant and remarkable for the tendency of the epidermis to crack in areas. The thin margin is often split. The species belongs to the same group as $C$. caninus and C. azureus, from both of which it differs in its rimose pileus and distant lamelle. The color of the young pileus is suggestire of that of Tricholoma personatum.

\section{Gomphidius nigricans $n$. sp.}

Pileus convex or nearly plane, pale brownish-red, corered with a tough gluten which becomes black in drying, flesh firm, whitish; lamella distant, decurrent, some of them forked, white becoming sinoliy-brown, black in the dried plant; stem subequal, longer than the cliameter of the pileus, glutinous, solid, at first whitish especially at the top, soon blackish by the drying of the gluten, whitish within, slightly tinged with red toward the base; spores oblong-fusoid, .0006 to $.001 \mathrm{in}$. long, $.0002 \pm$ to .0003 broad.

Pileus 1 to $2 \mathrm{in}$. broad; stem 1.5 to $2.5 \mathrm{in}$. long, 2 to $t$ lines thick.

Under pino trees. Westport. September.

This species is easily known by the blackening gluten which smears both pileus and stem and even forms a veil by which the lamelle in the young plant aro concealed. In the dried state tho whole plant is black. 


\section{Hydnum scabripes n. sp.}

Pileus fleshy, firm, convex, glabrous, pinkish-gray, the decurved margin extending beyond the aculei, flesh white; aculei whitish or subcinereous, becoming ferruginous-brown, decurrent; stem stout, nearly equal, scabrous-dotted; spores subglobose or irregular, somerwhat nodulose, colored, .0003 in. broad.

Pileus 4 to $5 \mathrm{in}$. broad; stem \pm to $5 \mathrm{in}$. long, about 1 in. thick.

Under hemlock trees, Tsuga Canadensis. Elizabethtown. September.

The prominent characters of this species are its peculiar color and its scabrous or rough-dotted stem.

\section{Radulum molare Ir.}

Dead bark of elm, Ulmus Americana. Cooperstown Junction. June.

I have seen no description of this species which gires the spore characters. In our specimens the spores are naviculoid-elliptical, $.0003 \mathrm{in}$. long, .00016 to .0002 broad. Sometimes the plant is effuso-reflexed, in which case the upper surface of the pileus is coarsely strigose or fibrous and somewhat resembles the pileus of Merulius tremellosus.

\section{Pyrenochaeta collabens n. sp.}

Perithecia .014 to .018 in. broad, superficial, crowded or closely gregarious, submembranous, subglobose, often collapsing when old, tho upper part sometimes falling away and leaving a cup. shaped base, black, the setie few, black, mostly near tho base of the perithecia; spores narrowly elliptical, nearly colorless, .0003 to .00045 in. long, .00016 to .0002 broad.

Bark and wood of apple tree. Alcove. October to January. C. L. Shear.

\section{Vermicularia Hepaticæ n. sp.}

Perithecia minute, .003 to $.00 t$ in. broad, epiphyllous, furnished with black diverging setwe which sometimes have one or two septa near the baso; spores narrowly fusiform, slightly curved, acute at each end, .0007 to $.0009 \mathrm{in}$. long, sometimes appearing to be spuriously septate in the middle.

Dead spots on leares of Hepatica acutiloba.

Helderberg mountains. July.

This fungus sometimes occurs in company with Protomyces fuscus. It is so small that it is scarcely risible to the naked eye. 
Vermicularia Schœnoprasi Auers.

Dead leaves of wild leek, Allium tricoccum.

Piorrepont Manor. June.

\section{Sphæropsis ulmicola $E$. C $E$.}

Deal branches of elm, Olmus Americana. Cooperstown Junction. June.

In our specimens the perithecia are sometimes collected in clusters of tro or three as in the genus IIaplosporella, and they are erumpent and exposed, not covered by the epidermis. The spores are very pale, almost hyaline. But in other respects they agree well with the description of the typical form.

\section{Diplodia subtectoides $n . s p$.}

Perithecia small, numerous, erumpent, arranged in a somewhat seriate manner or in short interrupted straight or flexuous lines; spores obovate or elliptical, continuous or uniseptate, .0005 to $.0006 \mathrm{in.}$ long, .00025 to .0003 broad.

Dead bark of maple, Acer saccharinum. Alcove. November. Shear.

'T'his species may be separated from its near relative, $D$. subtecta, by its smaller spores, with simple ones often intermingled with those of normal form.

\section{Septoria centaureicola Brun.}

Living leaves of seedling plants of bluebottle, Centaurca Cyanus. Menands. November and December.

In our specimens the spores are a little shorter and broader than the dimensions given in the description of the typical form. The plant is thereforo designated Variety brevispora. Spores .0012 to $.0016 \mathrm{in}$. long, .00012 broad.

\section{Septoria Divaricatæ E. E E.}

Living or languishing leaves of divaricate phlox, Phlox divaricuta. L'ierrepont Manor. June.

\section{Tolyposporium bullatum (Schrce.)}

In the ovaries of barnyard grass, Panicum crus-galli var. muticum. Whitehall. September. 
In our specimens only a few of the ovaries of a panicle are affected. These strell to an unusual size. They are green or greenish externally, and are filled with a mass of olive-brown spores collected in glomerules varying much in size and shape.

\section{Ovularia decipiens Sacc.}

Living or languishing leaves of buttercups, Ranunculus acris. Alcove. June and October. Shear.

\section{Cylindrosporium Padi híurst.}

Living leaves of cultivated plum, Prunus domestica. Helderberg mountains. September.

Some mycologists appear to have confused Septoria cerasina Peck, with this species, but the two are clearly distinct and may ensily be separated at a glance. In $S$. cerasina tho sporos ooze out in a gelatinous mass or in tendrils; in this species they form a white flocculent mass on tho surface of the matrix as do other species of this genus.

\section{Cladosporium carpophilum Thum.}

On peaches. Menands. August and September. The fungus forms small olive-green spots on the fruit. Sometimes these spots become confluent and form patches. They are often more numerous on one side of the peach than on the other, and the affected side fails to derelop as rapidly as the other, giving the fruit a flattened or deformed appearance, and the flesh beneath the fungus is more tough and less succulent than the unaflected part. The fungus is, therefore, to bo classed anong the injurious species.

\section{Dendryphium nodulosum Sacc.}

Dead stems of bleeding heart, Dicentra spectabitis. Menands. April.

The fungus bears some resemblance to IIelminthosporium interseminatum, but is separable even by the naked eye, by reason of its more ferruginous color.

\section{Coniothecium Rubin.sp}

Thinly effused, olive-green; spores coalescing in glomerules varying much in sizo and in the number of component spores or cells, separate spores .0006 to .0007 in. broad, glomerules about $.0016 \mathrm{in.} \mathrm{broad.}$ 
Injured stems and branches of cultirated raspberry. Menands. April.

The fungus is found in places where the epidermis has been broken or removed by the swaying of the plants in the wind and rubbing against each other. Numerous hyaline elliptical spores about .0003 in. long, .0002 broad, are intermingled with the larger spores of the species.

\section{Sphærella rubina $n . s p$.}

Perithecia minute, .007 to .009 in. broad, commonly gregarious, sometimes forming extended patches, submembranous, obscurely papillate, pertuse, subglobose or depressed, at first covered by the epidermis, becoming superficial when the epidermis falls away, black; asci cylindrical, subsessile, .003 to .0035 in. long, .00015 to .0005 broad; spores uniseriate or subbiseriate, oblong, obtuse, uniseptate, generally constricted in the middle, hyaline, $.0006 \mathrm{in}$. long, $.0002 t$ to .0003 broad, the upper cell often a little larger than the lower.

Stems of cultivated raspberries. Menands. April and May.

This species is injurious to the plants it attaclis. The affected plants either die from the disease or are so weakened by it that they are winter-killed wholly or in part. Generally the epidermis is whitened over the patches of the fungus, but sometimes brown spots indicate the presence and location of the fungus. The mycelium consists of brown septate filaments. From Didymella applanata, which this fungus resembles in some respects, it is separated by the absence of paraphyses.

Diaporthe robusta $n . s p$.

Pustules numerous, erumpent, surrounded by a black circumscribing line and covered by a black crust; ostiola obscure or prominent and distinct; asci subfusiform, .003 to .0035 in. long, .0006 broad in the widest part; spores crowded or biseriate, oblong-elliptical, obtuse, strongly constricted in the middle, .0005 to $.0007 \mathrm{in}$. long, .00025 to .000 s broad, each cell usually containing a single largo nucleus.

Bark of maple, Acer saccharinum and Acer dasycarpum. Ganseroort. Peck. Alcove. Shear.

This species is allied to $D$. acerina, but is distinguished from it by tho more numerous pustules, lugger asci and larger, more obtuse and more strongly constricted spores. 
Cucurbitaria Comptoniz E.\&E.

Dead stems of sweet fern, Comptonia asplenifolia. Cooperstown Junction. June.

\section{REMARKS AND OBSERVATIONS. Hesperis matronalis $L$.}

This introduced plant is abundant along the Susquehanna river near Binghamton. $\quad T ., T$. Clute.

\section{Rosa blanda $A$ it.}

The fruit of this species is described as globose. On the hills near Elizabethtown, specimens were found in which tho fruit was pointed at the base and subpyriform. These were sometimes intermingled with fruit of the normal form, even on the same plant. The stems of some of the plants were quite prickly toward the base. The species is manifestly quite rariable, and in this case the variation is toward the western Rosa Sayi.

\section{Eupatorium perfoliatum.}

A form of this plant occurs near Sholsan, in which tho flower heads are purplish.

\section{Aster cordifolius $T$.}

Tho white-rayed form occurs occasionally about Whitehall, also near Westport.

Aster lrvis $T$.

The prevailing form of this beautiful aster, about Whitehall, has all the leares, except the two or three lower ones, very narrow and tapering from the base to the apex. They are from three to six lines broad and three to six inches long.

\section{Aster paniculatus Lam.}

A form grows about Whitehall in which the stems and branches are slender and weak or half reclining, and the flower heads are more scattered than usual.

\section{Aster longifolius $L a m$.}

The plant reported under this name in the Thirty-fourth Repcrt proves to be another species, but what I now take to be 
tho truo species was found along the Oswegatchie rirer abore Cranberry lake and between Sternbergs and "The Plains." It is a northern species, and will probably not be found as far south as the Catskill mountains.

Aster ptarmicoides $T \cdot \& G$.

Rocky ledges east of Thitehall. September.

\section{Bidens connata Mruh.}

In the description of this species in the last edition of the Manual, "rays none" is giren as one of the prominent characters of the species, and in the description given in 'Torrey's Flora of New York, it is said that the rays are always wanting. Nevertheless plants of this species having conspicuous ray flowers were found about $W$ hitehall. Also Bidens cernua without rays is common there and in other places farther north.

\section{Senecio Robbinsii Oakes.}

Rocky cliffs east of Whitehall, in company with Astor ptarmicoides.

Thymus Serpyllum $I_{\text {. }}$

Stephentown, Rensselaer county. A. K. IKarrison.

Stachys palustris $L$.

Dry gravelly hillsides. Lebanon Springs. August. Ilarrison.

This species, according to tho botany and as indicated by tho name, commonly grows in wet grounds. But in the locality mentioned it has been found only in patches on dry ground. The plants are small and starved in appearance, probably the result of uncongenial surroundings. The form previously referred to this species as variety aspera is now classed as a distinct species, and until now the typical form, or true $S$. palustris, has not been represented in the State IIerbarium.

\section{Polygonum Douglassii Greene.}

This plant grows in thin soil covering rocks on Cobble hill near Elizabethtown. It was first found near the summit, but it occurs also near the base. Its branches are usually rather long, slender and somewhat straggling, bent or croolied. It blossoms as late as September. 'Tho sepals are greenish or red. The fruit is drooping and drops easily. 
Polygonum nodosum Pers.

Shore of Lake Champlain near Rouses Point. September.

\section{Potamogeton heterophyllus Schreb}

Both variety maximus and variety minimus are found in Warner's lake, near East Berne. The latter was in fruiting condition in September, but the former at the same time bore no fruit, although it had flower spikes.

Panicum capillare $I_{\text {. }}$ var. flexile Gatt.

Rocky places near Whitehall. September.

Muhlenbergia sobolifera Trin.

This grass is found as far north as Whitehall, where it grows in dry soil about rocky cliffs.

\section{Lycopodium clavatum $L$.}

A singular sterile form of this clubmoss was found by Mr. Harrison near Lebanon Springs. The usual peduncles, instead of terminating in fruiting spikes, are excessively prolonged, some of them being 12 or 14 inches long, and they remain wholly sterile, no fruit spike dereloping.

Tricholoma terreum Scheff. var. fragrans Peck.

Near Ticonderoga, also near Elizabethtown. September.

If this species was not very variable, the rariety here noticed might easily be regarded as a distinct species. It has a decided farinaceous odor and flavor, tho pileus becomes paler with ago and the young moist flesh, which is brownish, fades to white when dry. The lamellix are rather thin, close and adnate, and the stem, in some forms at least, is solid and white.

Hebeloma Colvini $P$. var. velatum n. var.

Scattered or caspitose; pileus conrex, plane or even slightly depressed, brittle, obtuse or umbonate, adorned with a tomentose veil, which either disappears with age or persists and makes the pileus obscurely floccose-scaly or its margin silky or floccose; lamellix rather close, subrentricose, adnexed; stem equal, brittle, hollow, silky-fibrillose and often somewhat floccose-squamose toward the base, sometimes annulate with a thick, soft, cottony 
ring; spores subelliptical, even, .000t to .0005 inch long, .00024 to .0003 broad.

Pileus 1 to 2.5 inches broad; stem 1.5 to 2.5 inches long, 2 to 3 lines thick.

Gravelly ground under cottonwood trees, Populus monilifera. Rouses Point. September.

Three forms were found growing together. The first and most abundant has the mature pileus glabrous or slightly silky on the margin only; the second has the grayish or reddish gray pileus adorned with appressed floccose scales; the third differs from the second only in the dark chestnut color of the pileus. The veil is grayish-white and when well dereloped it adberes partly in fragments to the margin of the pileus and partly as an annulus to the stem. The cavity of the stem is rery small. A slight odor like that of radishes is perceptible. The species belongs to the section Indusiati. The variety differs from the typo especially in its strongly developed veil.

Poria attenuata $P$. var. subincarnata n. var

This differs from the typical form in the paler color of the pores. It grows on hemlock bark and forms small patches rarely more than one inch in diameter. Alcove. September. Shear.

\section{Septoria Cucurbitacearum Sacc.}

A form of this fungus sometimes derelops on the fruit of squashes. It produces small orbicular whitish spots on which the perithecia dorelop. The epidermis on these spots sometimes ruptures in a stellate manner. Menands. Novomber.

Septoria Dentariæ $1 \%$. var. arida $n$ var.

Living leares of Dentaria diphylla. Pierrepont Manor. June. Spots definite, arid, whitish. Otherwise like the type.

(E.)

NEW YORK SPECIES OF CAREX.

By E. C. HOWE, M. D.

The object of the following monograph of the species of Carex hitherto found in the Stato of Now York is to aid young botanists in acquiring a knowledge of these interesting but too often much neglectod plants. It has been too much tho custom to omit 
the study of them until nearly erery other genus has received attention. That beginners in the study of botany should distrust their ability to cope with these plants is not strange, since both teacher and text-book have sometimes warned them to "beware of this extremely difficult genus, as none but the most experienced should approach it." This should not be so. There certainly are difficulties to be encountered, but they are no more formidable than those with which we meet in other genera, such as Aster, Euphorbia and Aspidium. If we except two or three groups containing two or three species each, and certain allied forms which have been considered good species in one generation and mere varieties in another, and which are now considered species by one botanist and rarieties by another, if we except these which are less than a dozen in number, there are no serious difticulties in the study of the carices.

Specimens with mature fruit are desirable and even necessary for the satisfactory identification of species of this genus, for the descriptions are based upon such specimens, the fully developed spikes, perigynia and scales furnishing the most distinctive and reliable specific characters. The perigynia, or a few of them, should bo removed from the rachis for study, for in this way their characters are more clearly seen. Ordinarily the achenia or seeds are neglected, but in some instances they furnish import. ant distinguishing characters, and will be a valuable aid to a beginner in deciding upon the identity of certain closely related species. C. lupulina and C. Jupuliformis are cases of this kind.

In the descriptions that follow, the plan is to define the characters of ench species fully, clearly and minutely without reference to its likeness to other species. 'I'his has been done even at the risk of being thought unnecessarily repetitious. Measurements of the different parts of the plant hare been freely given, and it is beliered that in many instances they will be found a most satisfactory aid in the identification of the species.

Varieties are compared with the typical form of the species.

Carex $I$.

Flowers of two kinds, one staminate, consisting of three sta. mens in the axil of a scale-like bract (scale), the other pistillate, consisting of a pistil terminating in two or three stigmas and forming in maturity a dry hard len icular or triangular seed 
(achenium) enclosed in a thin or membranous seed ressel (perigynium), which is also in the axil of a scale-like bract; both linds of flowers arranged in spikes which are staminate (sterile) when composed of staminate flowers, pistillate (fertile) when composed of pistillate llowers, and androgynous when composed of both kinds. The spikes may be either sessile or borne on a peduncle, and they are usually subtended by scale like or foliaceous bracts. When both linds occur on the same plant the inflorescence is monocious, on different plants, diocious. The stems or culms aro triangular and solid; leaves three-ranked, narrow, linear or setaceous, often rough on the margins, clasping the stem at the base and forming a closed sheath around it.

Perennial herbs growing chiefly in wet, moist or strampy places, and most of them perfecting their fruit in the first half of the summer scason. They may be distinguished from the true grasses by their triangular solid stems, their closed sheaths and their seed being wholly and singly enclosed in a thin seed ressel.

For the sake of brevity the following characters have been omployed :

The sign of degrees $\left({ }^{\circ}\right)$ stands for "foot" or "feet."

The sign of minutes (') stands for "inch" or "inches."

The sign of seconds (") stands for "line" or "lines."

The dash between two numbers stands for "to," and with the numbers indicates the degree of variation in measurement.

\section{SrNorsis of THE Grodrs.}

$\Lambda$. Staminate and pistillate flowers in small globoso or oblong androgynous spikelets placed one abovo the other and forming clusters or interrupted spikes or heads at the summit of tho culm, or panicled heads (decompound) in 3,4 and 5 . Sometimes the lower spikelets in several species are branched. ANDROGXEL.

* Stigmas 2; achenium lenticular.

+Spilielets staminate at tho apex, pistillate below.

Spikelets 2-5 flowered, capitate or in a short interrupted spiko; root-stoch cxtensively creeping. 1-2.

Spikelets in a close or open paniclo or densely clustered in an interrupted spike 1'-4' long or more; perigynia blackish-brown or tauny. 3-5. 
Spikelets contiguous abore, separate below, or all contiguous, sometimes the lower ones compound; perigynia lanceolate, without a distinct margin, divergent. 6-7.

Spikelets approximate abore, separate below, or all contiguous, (capitate in 10); perigynia with a distinct margin, widely divergent or reflexed at maturity. 8-13.

† Spikelets staminato at the base, pistillato above.

Spikelets 3-8, 3-5 flowered, the upper ones approximate or subdistinct, the lowest distinct or remote (capitate in 15), or 12-30 flowered and disposed in an interrupted spike $11^{\prime}-2 y^{\prime}$ long, silveryyreen and shining; perigynia spreading but not reflexed. $14-17$.

Spilielets 3-8, tho upper 2 or 3 approximate, separate below, or all contiguous (spikelet single in 18); perigynia slightly concave, widlely divergent or retcxed at maturity; plants bright green becoming yellowish. 18-21.

Spikelets 3-15 or more, aggregated or approximate, or the upper contiguous and the lower separate (clustered in 31); perigynia concare, thin, mostly wide winged-margined, the tips erect or spreading, not reflexed. 22-31.

+ Staminate and pistillato flowers rariously situated; spiliolets often wholly sterile or wholly fertile. 32-3t.

* Stigmas 3; achenium triangular.

Flowers borne in a short spitie or head, staminate at the apex, pistillato below; pistillate scales small, calucous, tho staminate mostly cunspicuous. $35-36$.

Pistillate scales green and leaf-like, persistent, the lowest as long as the spike; perigynia globular, with a long slender beak. $37-39$.

B. Staminate and pistillate flowers disposed in separato spikes on the same culm or plant (monoecious), or on separate plants (diocious), tho former frequently androgynous.-CAREX proper.

* Stigmas 2 (rarely 3 ); achenium lenticular.

Plant dixcious. Sterile spike linear, 5" long or less; fortile spike $3^{\prime \prime}-5^{\prime \prime}$ long, densely tlowered; perigynia oblong, reflexed at maturity. 40 .

Sterile spikes 1-4, stalked or sessile; fertile spilies 2-5, erect or recurved, sessile or short stalked, densely or subdensely flowered; perigynia with a short point or pointless; scales blackish-purple or reddish-brown, not awned. $41-46$. 
Fertile spikes $2^{\prime}-4^{\prime}$ long, pendulous on stalks $1^{\prime}-2^{\prime}$ in length or more; perigynia slightly turgid, scales light brown with long rough awns. $47-48$.

* Stigmas 3 ; achenium triangular.

† Perigynia biconvex, without a beak.

Sterile spike single, (rarely 2 or 3 ) stalked; fertile spikes 2-4 on filiform droopiny peduncles, the upper approximate, the lower sometimes distant; perigynia with a minute point or pointless; scales blackish-purple or brown. 49-51.

Spilies 2-5, the upper half or more of the terminal one fertile, sterile below, the others fertile, sessile or short-stalked, erect, green or dark purple; perigynia sinooth or pubescent. 52-54.

+Perigynia obtusely 3-angled, not compressed, mostly contracted at each end; obtuse or acutish at the apex.

Sterile spike cylindrical, usually fertile at the apex; fertile spikes $2-5$, linear or cylindrical, densely or loosely flowered, on drooping or suberect partly included peduncles (sessile or shortpeduncled and mostly erect in 55); bracts leafy, usually surpassing the culm; perigynia orate-oblong or elliptical, nerved, contracted at each end, the apex entire or pointed and notched. $55-58$.

Sterile spilie single (sometimes 2 or 3 in 59), clavate, longpeduncled; fertile spikes $2-4$, sessile or stalked, erect, mostly distant, or remote (the upper.2 approximate in 60 ); bracts shorter than the culm or about equaling it in 59 and 63 ; perigynia with a short terete beak in $61.59-63$.

Sterile spike short-stalked or sessile; fertile spikes 2-5, cylin. drical or oblong, densely or subdensely flowered, the upper 1 or 2 usually sessile at the base of the sterile spike, the others subdistant or the lowest remote, stalked and erect (all approximate in 64); bracts leafy, longer than the culm; perigynia oblong, obovate, or ovate, nerred, without a beak. 6t-67.

† Perigynia with a distinct beak.

Sterile spike long or short-stallied ; fertile spikes loosely 2-8 flowered, the upper 1 or 2 sessilo near the base of tho sterilo spilie, the others distant, sometimes remote, erect, subflexuose; perigynia densely striate-nerved, with a straight or obliquo beak; leares and bracts thin, bright or glaucous green. 65-69. 
Sterile spike clarate or linear, sessile or stalled; fertile $\mathbf{2 - 5}$, usually the upper one $\mathrm{r}^{\mathrm{¿}}$ ¿wo sessile at the base of the sterile spike, the others scattered, tne lowest often remote, all on short or long peduncles and erect, or sometimes the one or two lower ones spreading; densely or loosely flowered; bracts leafy, partly sheathing, mostly exceeding the culm; perigynia orate, oborate or suboral, nerred, with a short, abruptly bent, or long tapering recurved bifid beak (the latter short and barely curred in 74 ; fruit easily detached. $70-74$.

t+ Perigynia acutely angled.

Sterile spilie clarate, short or long-peduncled; fertile spikes 3-5, mostly scattered on long filiform ïrnoping or erect-spreading peduncles. Leares narrow, three-reined. 75- 76 .

Sterilo spilie clarate, stalked; fertile spikes $2-5$, mostly distant on erect, partly or wholly included stalls, 3-S flowered; bracts as long as the sheaths or obsolete. Leares $3^{\prime \prime}-12^{n}$ wide or more, three-reined, (narrow and one-reined in S0). $7 \tau_{-}$S0.

$+\uparrow$ Perigynia obtusely angled.

Sterilo spike linear, $\frac{1}{2}$ " wide; fertile spikes small, erect or drooping; bracts obsolete, or leafy and equaling their sheaths; perigynia minute, light or olivebrown. Leaves setaceous, or involute when old 81-52.

Plant diecious. Fertilo spilio cylindrical, dark purple; perigynia orate, densely pubescent. A mountain species. 83.

Sterile spilio clarate or linear, sessile or short-peduncled ; fertilo spikes 1-5, the upper one or two near the aterile, the others subapproximate or sometimes subdistant and the lowest remoto, (umbellate in St), 3-10 densely or subloosely flowered, globose or short oblong, mostly sessilo; perigynia subrotund, suboval, obovate or ova!e, densely or lightly pubescent, with an abrupt bifid beak; bracts mostly scale-like, sometimes short leaf-like, (perigynia acutely angle:l in 93.) $8 \pm-93$.

t+ Perigynia slightly intlated.

Sterile spilie clavate or linear, stalked, often fertile at tho apex; fertile spikes 2-4, straight or flexuose, cylindrical or subclavate, densely or loosely flowered; bracts leaf-like, the lorrest sheathing, mostly exceeding the culm, (the upper ones setaceous in 98); perigynia three-angled, ovate or spindle-shaped, with a long or short tapering beak. $9 \pm-98$.

t+ Perigyuia moderately inflated. 
Sterile spilies 1-5, stalked or sessile; fertile spikes 2-5, cylindrical or oroid, densely flowered, approximate above and distant and remote below, short peduncled or sessile, erect or the lower sometimes long-peduncled and spreading; bracts shorter or longer than the culm; perigynia oroid or oblong-conical, nerred, densely hairy or smooth, with a short bidentate beak; mostly coriaceous in texture, (rranular dotted and thin in 103). 99-106.

Sterile spilies $1-5$, stalked ; fertile spilies $2-5$, cylindrical, densely or subdensely flowered, ereet on short stalks or sessile; perigynia ovate lanceolate, smooth or hairy, with a long tapering deeplyclefi beak, the awn-like teeth mostly recurred; perigynia not reflexed. 107-109.

Sterile spike single; fertile spilies $2-4$, cylindrical, on long drooping peduncles; perigynia narrowly lanceolate, with a long deeply-cleft beak, the awn-like teeth spreading or resurved; perigynia strongly reflexed at maturity. 110-111.

+十 Perigynia much inflated.

Stcrile spike solitary, (very rarely 2), stallied; fertile spikes $2-5$, cylindrical, densely flowered, the upper 2 sessile or nearly so, ascending, the others subdistant, short-stalked and horizontally spreading or all separate on drooping peduncles, the lowest sometimes remote, $2^{\prime}$ long or more, $5^{\prime \prime}-6^{8}$ wide; perigynia ovoid, nerved, with a long bilid beak, horizontally spreading at maturity, having a comose appearance. A mountain species (11t) has 1-3 straw-colored spilies, sessile, erect or ascending, "3" wide, with ascending perigynia. 112-11t.

Sterilo spike long and sometimes long-peduncled; fertile spikes $11^{\prime}-2 \frac{1}{2}^{\prime} \operatorname{long} g, 9^{\prime \prime}-12^{\prime \prime}$ wide on still erect stalks or sessile; perigynia ventricose and stipitate, $6^{\prime \prime}$ in length or more. Spikes hop-like in aspect. $115-116$.

Stcrile spitie single (sometimes 2 in 122), stalked or sessile; fertile spilies 1-6, globular, ovoid or oblong, compactly or loosely flowered, the upper two sometimes contiguous, the others separate, or all distant or remote, sessilo or pedunculate, rigidly erect, bright or yellowish green; bracts with or without sheaths, mostly surpassing the culm; perigynia ovoid or lanceolate from an orate base, or atw-shaped, nerved, smooth, with a long tapering bidentate, or short notched bat, horizontally spreading or reflexed at maturity. 117-125. 
Spikes 1- 1 , rarely 5, the upper half or more of the terminal one fertile, sterile below, the others all fertile, cylindrical, $9^{\prime \prime}-12^{\prime \prime}$ long, $4^{\prime \prime}-6^{\prime \prime}$ Tide, stalked, erect; perigynia with a stender beak longer than the body, horizontally sprearling when mature. 126.

Sterile spities 1-5, clarate or cylindrical, stalked, sometimes androgynous; fertile spilies $1-5$, clustered or scattered, or the upper 2 approximate, the others subdistint or distant, pedunculate or sessile, mostly erect or ascending (pendulous and loosely flowered in 133) the lowest sometimes spreading, densely tlowered, frequently sterile at the apox, cylindrical or oblong; perigynia globular-oroid or orate-lanceolate, nerred or nerveless, mostly much-inflated and thin, straw-colored or tawny, ascending, widely divergent or reflexed, with a tapering bidentate beak, the latter needle shaped in 133. 12\%-133.

\section{Dfscriptions of Grodps and Species.}

A. Staminate and pistillate flowers intermingled in small globular or oblong spikelets which form clusters, heads or spilies or are panicled in $3, \pm$ and 5 .

Stigmas 2; achenium lenticular.

Spikelets staminate above, pistillate below.

Inflorescence simple, both staminate and pistillate flowers found in the same spilie or spikelets.

Spilielets 2-6, 2-5 flowered, in a short interrupted spike, or aggregated in an oroid head; perigynia ovate, nerved, of a thick coriaceous texture, with a minute entire or notched point; bracts scale-like, the lowest bristlepointed; rootstock extensirely creeping.

Culms slender, leafy at base; spikelets distant...... tenella.

Culms rigill, naked; spikelets capitate........... chordorkiza.

\section{Carex tenella Schk:}

Stems $6^{\prime}-1 S^{\prime}$ high, slender, erect or spreading, rough abore; leares about equaling the culm, $\frac{1}{2}$ wide or less, thin, slightly rough on the margins, the loosely tufted radical leares longer, about $1^{\prime \prime}$ wide, suberect or spreading; spike $\frac{1}{2}-1^{\prime}$ long; spikelets $2-t$, separate, the lorest usually with a bristle-shaped bract $y^{\prime}-1^{\prime}$ in length, 1-1 flowered, the highest rarely 6 flowered; perigynia orate or elliptical, subterete, $11^{\prime \prime}$ long, prominently finely nerred, the 
apex tipped with a short entire point; scale orate, acute or mucronate, thin, white, about one-half the length of the perigynium.

Readily distinguished by the naked or unprotected appearance of the well-rounded perigynia.

A small form occurs which is $4^{\prime}-6^{\prime}$ high, rather rigid, with 3-5 spilielets and the bristle shaped bract of the lowest spikelet often wanting.

Siramps and wet places. Not rare. June.

\section{Carex chordorhiza Ëhrh.}

Stems $6^{\prime}-1 S^{\prime}$ high, erect, smooth, naked, or the prominent basal sheaths terminating in narrow blades $\frac{1}{3}-1^{\prime}$ in length; leafstems branching and rooting at the base, springing from the large creeping rootstock, $3^{\prime}-5^{\prime}$ high; leares rariable in length, the lower $\frac{1}{3}-2^{\prime}$ long, those above, usually partly tufted, $3^{\prime}-6^{\prime}$ in lengtb, erect or spreading, $1^{\prime \prime}$ wide or less, flat or involute, rough margined; spilielets $3-5$, agrregated in an oroid head $3^{\prime \prime}-6^{\prime \prime}$ long, brown; perigynia elliptical-orate, biconrex, nerred, $11^{\prime \prime}$ long, contracted into a short entire or notched beak about the length of the ovate, acute brown scale; bracts scale-lilie and inconspicuous except the lowest which is sometimes short setaceous.

Easily determined by its chord-like, extensively creeping rontstock.

Sphagnous swamps and strampy shores of lakes and streams. Rare. July. Incrimer, Oneida and Seneca counties, and boggy margins of lakes in the North woods I'uine's Cutalogue.

Inflorescence branched, the spikelets panicled or densely clustered.

Perigynia biconver, blackish, shiuing. .......... 1

Perigynia compressed-ovate, not shining......... vulpiuoidea.

\& Periggnia ovate, stipitate ................. teretiuscula.

1 Perigyia oburate, sessile.................. decomposita.

3. Carex teretiuscula Good.

Stems 1S'-30' high, slender, erect, obtusely angled, rough near the spike; leaves usually shorter than the culm, $1^{\prime \prime}-1 \frac{1}{2}^{\circ}$ wide, somewhat involute when dry, rough on the edges; spike panicled, 1'-2' long, brown; spikelets small, crowded on short 
appressed branches, or the 2 lower sometimes distinct; bracts scale-like, acuminate, the lowest bristle-pointed; perigynia stipitate, somerhat thick and corky, orate, faintly nerved at the truncate base, dark brown and shining, tapering abore into a slender, bifid, greenish beak, nearly corered by the orato acute brown scale.

The small, short-stalked, orate, acuminate, shining perigynia, as well as the short, appressed branches of the narro: panicle distinguish this species. Not rare in swampy fields. June.

Var. ramosa Boott. Head longer and somewhat nodding, spikelets compound, sometimes on appressed branches, looser or more scattered. Albany county.

\section{Carex decomposita Muhl.}

Stems $20^{\prime}-36^{\prime}$ high, tlaccid, erect or spreading, smooth; leares exceeding the culm, stiff, channeled below, $2^{\prime \prime}-3^{\prime \prime}$ wide, roughmargined, filiform at the end; spilio decompound, 2'-5' long, dark or sometimes blackish-brown when mature; spilielets numerous on spreading branches, the lower of which are distinct or sometimes separated $y^{\prime}-y^{\prime}$ or more and $1^{\prime}-y^{\prime}$ long, those above shorter and less distant, gradually tapering to the dense apex; bracts of the long branches green and filiform, the others scaleliko and awn-pointed; perigynia sessile, thick, corky, rounded or oborate, biconrex, nerred on both sides, dark-brown and shining, abruptly contracted into a short bilid beak; scale thin, orate, pointed or cuspidate, tamny or brownish.

This species differs from others of similar growth in its thick, nearly round stem, in its stiff, long, slender-pointed leares, and especially in its panicled spikelets.

Swamps. July. Very raro or local. Yates and Seneca counties. Paine's Catalogue.

\section{Carex vulpinoidea $M r x$.}

Stems $1 \frac{1}{2}^{\circ}-21^{\circ}$ high, firm and erect, acutely angled and rough abore the smooth terete base; leares rough-margined, $1 \frac{1}{2}{ }^{\prime \prime}-2^{\prime \prime}$ wide, slender pointed and often surpassing the culm; spiko $\frac{1}{2}-4^{\prime}$ long, dull brown or sometimes with a tinge of green; spikelets clustered on branches $3^{\prime \prime}-9^{\prime \prime}$ long, usually densely aggregated above, in the lower half the clusters are mostly $3^{\prime \prime}-6^{\prime \prime}$ apart; 
bracts prominent, bristle-form or the lower filiform and sometimes exceeding the culm; perigynia orate-acuminate or ovate-lanceolate, flat beneath, 2-3 nerved above, contracted into a narrow bilid rough-margined beak, about as long as the orato awn-pointed scale, widely divergent at maturity.

$\Lambda$ coarse, homely species, somowhat variable, but the main characters are too manifest to be confounded with any other species.

Common in swamps, ditches and fields. June.

Inflorescence simple or the lower spikelets sometimes branched; perigyua planoconrex, stipitate, thin, spongy at the base, marginless.

Spikes brown, perigynia compressed-ovate......... alopecoidea.

Spikes green, perigynia teretish-lanceolate........ stipata.

\section{Carex stipata $M$ Wulh.}

Stems $11^{\circ}-3^{\circ}$ high, erect, flaccid, the acute angles rough above the middle; leaves about as long as the culm, $1 \frac{1}{2}{ }^{\prime \prime}-2 \frac{1}{2}^{\prime \prime}$ wide, smooth, rough-margined; spikes $1^{\prime}-3^{\prime}$ long or more, light green; spikelets $6-15$, ovoid or oblong, contiguous abore, tho lower separate and sometimes branched, the lowest of ten $1^{1}-1^{\prime}$ in length; bracts bristle-form and inconspicuous or the lowest $\frac{1}{4}-1^{\prime}$ long; perigynia subterete, lanceolate, prominently nerved, $2^{\prime \prime}$ long, tapering from a stalked truncate base into a slender rough-margined bifid beak twice longer than the body, widely direrging at maturity; scale lanceolate, thin, limhtbrown, about ono.half the length of the perigynium.

Very easily determined by the fruit, or by the color and bristly appearance of the spikes.

Everywhere common in swampy fields. June.

Var. crassicurta Peck $n$.var. Spikelets $7-12$, aggregated in an oroid or oblong head $9^{\prime \prime}-12^{\prime \prime}$ long, tho perigynia horizontally spreadingr or somewhat deflexed at the base, giring the spike an unusually bristly appearance. 'l'his well-marked variety is of a deeper green, and has a more rigid aspect than the type, whereby it may bo readily recognized.

Var. subsecuta I'eck n. var. Spikes 21'-81' long; spikelets $9-12$, globular, or the lower short-oblong, all conspicnously distinct, pale green, mostly smaller than tho type, but otherwise agrooing wilh it. 


\section{Carex alopecoidea Tuckm.}

Stems $18^{\prime}-30^{\prime}$ high, erect, acutely angled, flaccid, rough on the angles abore; leaves about the length of the culm, erect-spread. ing, $1 \frac{1}{2}$ " $-2 \frac{1}{2}$ " wide, rough beneath and on the margins; spike $\frac{1}{2}-1 \frac{1}{2}$ long, brown; spikelets $6-10$, mostly aggregated, or the lower 2 or 3 sometimes distinct, the lowest sometimes with a few-flowered branch, ovoid or oblong, $2 \frac{1}{2}^{n}-3^{\prime \prime}$ long; bracts bristle-shaped, the 1 or 2 lower $\frac{1}{4}-1$ ' in length; perigynia compressed-orate, stalked and truncate or subcordate at the base, obscurely nerved on the upper surface, tapering into a flat rough-margined bifid beak, more or less divergent at maturity; scalo orate, acuto or cuspidate, brown with whitish margins above the michlle, nearly covering the brown, or sometimes greenish, perigynium.

Distinguished by its brown spike and compressed, stalked, obscurely nerved fruit. Not common. Mostly in tho central and western part of the State; rare in the eastern part. June, July.

Spikelets more or less aggregated, light or deep green (brownish in 13 when mature); perigynia compressed, sessile, distinctly margined.

Leaves $2 "-4 "$ wille................... 1

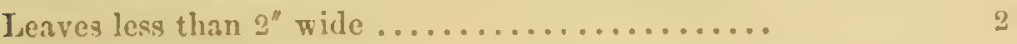

1 Spikelets distinct below................. sparganioides.

1 Spikelets contiguous or aggregated........... cephaloidea.

2 Spikelets densely aggregated in an ovoid head... cephalophora.

2 Spikelets contiguous in an oblong heal or approx-

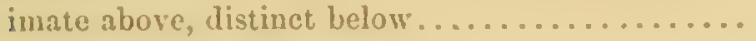

3 Perigynia orbicular-ovate................ Muhlenbergii.

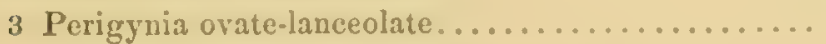

4 Beak of perigynia rough-margined . .........

4 Beak of perigynia smooth ............... retroflexa.

\section{Carex sparganioides $M\lceil u h l$.}

Stems $18^{\prime}-36^{\prime}$ high, erect, robust, smooth, except near the top; leaves numerous, light green, smooth except on the edges, $2^{\prime \prime}-4^{\prime \prime}$ wide, shorter or longer than the culm, the longest with filiform extremities; spikes $22^{\prime \prime}-6^{\prime}$ long, strict; spikelets $5-12$, the 3 or 4 upper globose, aggregated, the others more or less oblong, $1^{\prime}-1^{\prime}$ 
apart, the 2 or 3 lower $4^{\prime \prime}-8^{\prime \prime}$ in length, $22^{\prime \prime}-3^{n}$ thick, sometimes branched, slightly spreading on the straight or flexuose rachis; bracts bristle-shaped, inconspicuous ; perigynia $1 \frac{1}{2}$ " long, broadly orate, margined, nerreless, tapering or contracted into a short rough-edged, bidentato beak, usually dirergent but not reflexed at maturity; scale thin, white, orate, acute or cuspidate, about one-half as long as the perigynium.

A reduced form, $18^{\prime}-20^{\prime}$ high, with closer spikelets, usually occurring iu glades and on shaded rocky banks, is Var. minor Boott. This robust, handsome species is readily known by its ample graceful foliage and large strict spikes.

Common in rich soil about woods and in copses. June, July.

\section{Carex cephaloidea Dero.}

Stems $2^{\circ}-3^{\circ}$ high, slender, erect or weak and somewhat spreading, llaccid, the upper half rough on the angles, smooth below: leares shorter than the culm, $2^{\prime \prime}-3^{\prime \prime}$ wide, thin, smooth, roughmargined, dark green; spikes $\frac{1^{\prime}}{2}-\mathbf{l}^{\prime}$ in length, rarely capitate; spikelets 1-7, globose, contiguous, the two lower sometimes distinct or $2^{\prime \prime}$ apart, $2 \frac{1}{2}$ "long and broad, ascending; bracts incon. spicuous; perigynia $11^{\prime \prime}$ long or more, nerveless, dark green, soft, orate-lanceolate, tapering into a flat, rough-edged, bidentate beak, spreading at maturity; scale thin, white, short-orate, blunt, mucronate, about half as long as the perigynium; achenium oborate; style slightly enlarged at base.

Moist or sirampy places, mostly in woods or copses. June, July.

In the eastern part of the State this species is less common than the preceding ono to which it has sometimes been added as a rariety, but from which it is easily separated by its spilielets boing collected in an oblong head. From C. Muhlenbergii it is distinguished especially by its broader leaves.

\section{Carex cephalophora Mhhl.}

Stems $10^{\prime}-30^{\prime}$ high, stiff, erect, smooth or a little rough near the head, often branched at base as if stoloniferous; leaves rather stiff, the longest sometimes exceeding the culm, gradually tapering to a setaceous point, $1^{\prime \prime}-1 \frac{1}{3}^{\prime \prime}$ wide, smooth or the margins slightly rough; spiko capitate, ovato or short oblong, $3^{\prime \prime}-9^{7}$ long, palo green; spikelets $4-6$, globose, densely agrorregated, spreading; bracts 
setaceous, $3^{\prime \prime}-66^{\prime \prime}$ Iong, the upper mostly concealed by the crowded spikelets; perigynia $1 \frac{1}{2}$ " long, firm, sometimes faintly. nerved near the distinct margin, round-ovate, tapering into a short, rough edged, bidentate beak, widely spreading at maturity; scale white, thin, ovate, with a rough-a wned point, a little smaller than the perigynium; achenium round-orate, the short style with a conic base.

This is one of our commonest species and can not be confounded with any other. It grows in open fields and in and about woods and copses. June.

From forms of C. Mublenbergii, which sometimes approach it in the shape and size of the head, it is easily separated by its smaller perigynia.

\section{Carex Muhlenbergii Schk.}

Stems $15^{\prime}-30^{\prime}$ high, firm, erect, triangular, rough on the angles near the head, smooth below; leares shorter than the culm, $1 \frac{1}{2}{ }^{\prime \prime}-2^{\prime \prime}$ wide, open, flat, or sometimes slightly inrolute, smooth except on the margins, the ends slender and setaceous; spike $\frac{1^{\prime}}{2}-1 \frac{1}{2}$ in length, $3^{\prime \prime}$ broad or more, green; spilielets $4-9$, globose, contiguous, $2^{\prime \prime}-3^{\prime \prime}$ long, spreading or tho 3 upper erect; bracts bristle. shaped, conspicuous, $3^{\prime \prime}-6^{\prime \prime}$ long; perigynia $1 \frac{1}{2}{ }^{\prime \prime}-2^{\prime \prime}$ long, firm, broadly round-ovate, strongly nerved on both sides, terminating in a short, rough-margined, bidentate beak, spreading but not reflexed; scale orate, pointed or rough-awned, about as long as the perigynium; achenium round-ovate, the short style with a conical baso.

Common; growing in a rarioty of soil, but especially in light sandy or sterile places. In somo forms the head is ovate, resembling that of the preceding species. June.

Var. enervis Boott. Dilfers from the type in its slender, spreading, sometimes reclining stems, its soft leaves $1^{\prime \prime}$ wide, and its shorter spike and fewer-flowered spilielets, its smaller, liss firm, exactly orate, nerveless perigynia, the scale thin, mostly smooth. pointed or mucronate. This slender form is, perhaps, peculiar to south-eastern New York (Westchester county), where it inhabits open and slightly shaded grounds. The form which differs from the type only in its nerveless perigynia (Gray's Man.) occurs fartier north. Rensselaer county. 


\section{Carex rosea Schk}

Stems usually clustered, $1^{\circ}-2$ high, slender, erect, smooth; leares shorter or longer than the culm, $\frac{1}{2}^{\prime \prime}-1^{n}$ wide, smooth, roughmargined; spilies $1^{\prime}-13^{\prime}$ long, green; spikelets 16 , globose, the 2 or 3 upper contiguous, the others $2^{\prime \prime}-9^{\prime \prime}$ apart, 5-12 flowered; bracts bristle-shaped or filiform, extending from th oroid or deltoid base $1_{1}^{\prime}-2 \frac{1}{2}$; perigynia lanceolate, thin, nerseless, gradually tapering to a flat rough edged bidentate beak, twice longer than tho broad blunt thin white scale; achenium orate, apiculate.

The base of the beak above is usually clearly defined by an abrupt depression of the perigynium. The fruit is strongly dirergent or reflexed at maturity.

Very common and rariable. Woods and open places. June.

Var. radiata Dew. Culms almost capillary, 6'-12' high, the leaves often longer, $\frac{1}{2}^{\prime \prime}-1^{\prime \prime}$ wide, the spikelets $2-t$ flowered, the 1 or 2 lower often distant, each subtended by a filiform bract exceeding the culm; perigynia oral-lanceolate, erect or spreading; scalo broadly orate, obtuse or acutish, sometimes mucronate.

Var. minor Bnott. 'I'his differs from the last in its larger and longer culms, and its erect or ascending perigynia, their scales orate, acute or mucronate, or sometimes rough-cuspidate.

Var. pusilla I'eck, n. var. Stems $3^{\prime}-8^{\prime}$ high, stiff, smooth; leaves a little longer than the culm, ${ }_{2}^{\prime \prime}$ wide, rough-margined; spikelets 2-t, the upper 2 contiguous, the others $\frac{1}{1}$ apart, the lowest usually with a setaceous bract $\frac{y^{\prime}}{2}-1^{\prime}$ long, 3-9 flowered; perigynia orate-oblong, about one-third longer than the ovate obtuse or acutish scale, divergent but not reflexed.

Var. staminata l'ech, n. var. Stems 15 '-20' high, slender and somowhat spreading; leares $\frac{1}{2}{ }^{\prime \prime}-\frac{3}{4}$ " wide; spikelets $1-5$ flowered, each with tho staminate portion conspicuous and persistent, the mature perigynia horizontally spreading or rellexed.

\section{Carex rotroflexn Muhl.}

Stems tufted, 6'-18' high, firm, erect, smooth; leaves mostly shorter than the culm, $\frac{1}{2} "-1^{\prime \prime}$ widle, smooth, rough-margined; spikes $4^{\prime \prime}-10^{\prime \prime}$ ol more in length, light green, becoming brown when mature; spikelcts 3-5, globose, 3-9 llowered, tho upper contiguous, tho 1 or 2 lowor sometimes $2^{\prime \prime}-3^{\prime \prime}$ apart, tho lowest with 
a setaceous or filiform bract $3^{\prime \prime}-2 \frac{1}{2}^{\prime}$ long; perigynia ovate-icuminate or lanceolate, with a thick, spongy base, nerveless, tapering into a smooth-margined bifid beak, a little longer than the orate obtuse or pointed brown scale, reflexed at maturity; achenium broadly ovate, apiculate.

Separated from the last by its more rigid culms, its more aggregate spikelets, and by its smooth-beaked fruit.

Open woods and fields. Infrequent. June. It occurs chiefly in the southern central and western parts of the State. It is rare or wanting in the northern and eastern parts.

Spikelets pistillnte abore, staminate at the base.

Leaves mostly narrow, soft and spreading, shorter than the culm; spikelets 3-S, approximato or more or loss distant, (capitate in 15), silvery-green; perigynia plano-convex, orate, somewhat coriaceous or thickened at tho base, turning silvery or brownish when mature; bracts scalo-like or bristleform.

Spikelets commonly 10-30 flowered or more....... canescens.

Spikelets commonly $2-5$ tlowered.............. 1

1 Spikelets aggregated in a dense head ........... tenuillora.

1 Spikelets not arerregated..................

2 Leaves less than $1^{\prime \prime}$ wide................. trisperma.

2 Lenves more than $1^{\prime \prime}$ wide.................. Deweyana.

\section{Carex trisperma $D_{\epsilon}$.}

Stems $1^{\circ}-2^{\circ}$ high, rery slender, spreading, sometimes prostrate, smooth; leaves shorter than tho culm, about $\frac{1}{2}$ " wide, smooth except the margins, flat, soft and thin; spikelets $2-3$, the 2 upper $\frac{1}{4}-1^{\prime}$ apart or all $1^{\prime}-21^{\prime}$ distant, the lower with filiform bracts $\frac{1^{\prime}}{2}-2 \frac{1}{2}$ long, the highest sometimes with a setaceous bract $3^{\prime \prime}-5^{\prime \prime}$ in length, $2- \pm$ flowerel; perigynia oblong-ovate, prominently finely nerved on both sides, thick or coriaceous, suberect, terminating in a short entire beak; scale oblong-orate, pointed or obtusish, usually shorter than the perigynium, achenium elliptical, the base tapering.

Swamps and wet places. Common. June, July.

A form is sometimes found in sphagnous swamps with almost filiform leaves. 


\section{Carez tenuiflora Wahl.}

Stems $6^{\prime}-18^{\prime}$ high, slender or capillary, crect or spreading, mostly naked, smooth; leares smooth, flat and involute, $\mathbf{Z}^{\prime \prime}-1^{\prime \prime}$ wide, usually sborter than the culm; spike capitate, silvery green, b coming whitish at muturity; spikelets 2-t, 3-5 flowered, nggregated in an ovoid head, or rarely the lowest $2^{\prime \prime}-3$ " distant; bracts bristle-form, mostly shorter tban the spilie; perigynia orate oblong, thick, nerred, light-brown, beakless, nearly corered by the ovate-oblong whitish scale.

Stems tufted and branched at base, the shortest often firm and erect, the longest flexile.

The silvery-green spikelets collected in a head distinguish this very rare or local species. It has been reported from Oneida and St. Lawrence counties. Juno.

\section{Carex Deweyana Scho.}

Stems $1^{\circ}-2^{\circ}$ high, slender, erect or diffuse, smooth; leares numerous, smooth, slightly rough-edged, 1"-11." wide, shorter than the culm, pale green becoming yellowish with age; spikes $9^{\prime \prime}-2$ ' long, flexuous; spikelets $2-1$, the 2 or 3 upper ones approximate, the lowest distant or sublistant, 2-6 flowered, silverygreen; bracts bristle-shaped or filiform, tho 2 lower sometimes exceeding the culm; perigynia oblong-ovate, acuminate, obscurely nerved, thin, 2" long, with a long, rough-margined, bidentate beak; scale thin, whitish, oblong-acuminate or rough awned, as long as the perigynium.

Woods and open places. Common. June.

Easily recognized by the somewhat bristly aspect of the soft silvery spiliclets and the somewhat drooping or llexuous character of the spike.

\section{Carex canescens $I_{\text {. }}$}

Stems $15^{\prime}-30^{\prime}$ high, erect, rough above the middle; leares glaucous, smooth, the margins rough, $1^{\prime \prime}-11^{\prime \prime}$ wille, the extremities filiform, shorter than the culm, or the radical ones sometimes exceeding it; spilies $11^{\prime}-3$ ' long; spikelets $4-9$, densely 10 to 30 flowered, ovoid or globose, tho 2 or 3 upper ones approximate, the others $3^{\prime \prime}-12^{\prime \prime}$ apart, all more or less contracted at the base, silvery-green; bracts scale-like, sometimes with a bristle-shaped 
prolongation, or the lowest setaceous or leaf-like; perigynia ovate, nerred at the base, minutely punctate, whitish, tapering into a short bifid or entire beak, dirergent at maturity, a little longer than the ovate, acute or obtuse scale; achenium elliptical. Swamps and low wet places. Very common. May, June. Readily determined by its silvery spikes and glaucous-green foliage. Small, slender forms with fewer flowered spikelets, but glaucous foliage approach the following variety. A form occurs in Suffolk county in which the terminal spikelet is wholly staminate or bears but few perigynia.

Var. vulgaris Bailey. Differs from the type in its more slender, erect, or diffuso stems; its narrower, green, not glaucous, leaves; its fewer and smaller spikelets, with fewer flowers, and in its green, horizontally-spreading perigynia with more pronounced beaks and shorter scales.

Var. alpicola $W^{\prime} \iota h l$. Stems $6^{\prime}-15^{\prime}$ high, firm, erect or spreading; leaves green, $1^{\prime \prime}$ wide; spikelets $3-5$, globular, 6-15 flowered, the lowest sometimes with a filiform bract 2 '-21' $\operatorname{long}$, sometimes the next abovo with a bristle-shaped bract $t^{\prime}$ or more in length; perigynia green with brown spots or tawny; otherwise as in the preceding. $\Lambda$ lowland form has capillary stems $15^{\prime}-20^{\prime}$ high, leares $\frac{1 "}{2}$ wido or less; perigynia green slightly dashed with brown.

Spikelets 3-9 (single in 18) oroid or oblong, approximate abore, interrupted below, or all scattered; perigynia slightly concare, rough or smooth-margined, nersed or nerreless, usually strongly reflexed at maturity; bracts bristle-form or rarely tho lowest leaf-like. Plants rather rigid, green, often becoming yellowish with age. In all the species of this group the terminal spikelet appears to be stalked, the lower part being much contracted and clothed with the scales of the staminate flowers.

Perigynia ovate, small .................... 1

Perigynia ovate or ovate-lanceolate, large............ 2

1 Spikelets scattered; perigynia with a short smooth beak... seorsa.

1 Spikelets contiguous or approximate, perigynia rough-

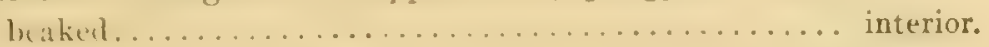

2 Spikelet single, sometimes wholly fertile or wholly sterile, exilis.

2 Spikelets approximate or scattered............... sterilis. 


\section{Carex exilis Dero.}

Stems $1^{\circ}-2^{\circ}$ high, firm, erect or suberect, rough above; leares involute, stiff, smooth, as long as the culm, or much shorter; spikes densely tlowered, cylindrical or short oblong, contracted at the base by the numerous scales of the staminate flowers, sometimes wholly staminate or wholly pistillate, ${ }^{\prime}-1$ ' long, light brown; perigynia ovate-lanceolate, few-nerved above, spreading, tapering to a flat, rough-margined bidentato beak, a little longer than the ovate-lanceolate scale.

Cold swamps in the northern and eastern parts of the State; also on Long Island. Rare. June, July.

This is a very distinct and easily recognized species. Sometimes an additional spilie or two may derelop at the base of the usual one.

\section{Carex sterilis Willd.}

Stems $15^{\prime}-30^{\prime}$ high, firm, erect, rough abore; leares rough on the edges, longer or shorter than the culm, $1^{\prime \prime}-2^{\prime \prime}$ broad, sometimes inrolute abore; spilie $\frac{1^{\prime}}{2}-1 \frac{1}{2}^{\prime} \mathrm{long}$, strict or flexuous, yellowish-green or tawny; spikelets $3-6$, globose, $2^{\prime \prime}-3^{\prime \prime}$ in length and thickness, $1 \frac{1}{2}-3^{\prime \prime}$ apart, or the upper 2 or 3 contiguous, the terminal contracted below and stalli-like from the sereral staminate scales, or sometimes all staminate or again each spikelet partly or wholly sterile; bracts scale-like or bristleform, tho latter $\frac{1}{x}-1^{\prime}$ in length; perigynia variable, ovate or evenly lanceolate, subcordate, one or both surfaces nerved, contracted into a short or long, narrow, rough-margined, sharply toothed beak, widely dirergent at maturity; scale ovate, obtuse or acute, whitish or brown, shorter than the perigynium; achenium ovate.

Culms with a single sterile spilie frequently occur, and more rarely with the lower balf of the spike fertile. 'The perigynia are mostly thin, but sometimes spongy at the base, strongly divergent at maturity, their bristling tips occasionally bent or dellexed.

Swamps and wet places. Tery common. May, June.

Var. excelsior Bailey. Differs from the typo in its taller, more slender culms, mostly $2^{\circ}-2 \frac{1}{2}^{\circ} \mathrm{high}$; its larger, greener, moro scattored spikelets, $3^{\prime \prime}-t^{\prime \prime}$ long; its larger perigynia prominently nerved on both sides, and in its oblong-ovate, acute or pointed scale. 
This and the following rarieties constitute the species C. stellulata $L$. of Gray's Man., 5th ed.

Common in swamps and wet meadows.

Var. cephalantha Bailey. Resembles the last, but has stouter, stiffer culms, $1^{\circ}-2^{\circ}$ high ; spilies $11^{\prime}-2^{\prime}$ long; spikelets $5-S, 15-30$ flowered, $3^{\prime \prime}-1^{\prime \prime}$ long, aggregated or approximate, sometimes becoming yellowish with age; perigynia horizontally spreading at maturity.

Long Island. May, Juno.

Var. xquidistans Peck n. var. Stems $12^{\prime}-30^{\prime}$ high, rough, stout, or rarely slender; spilies $11^{\prime}-21^{\prime}$ long; spikelets 4-6, 15-30 flowered, globular or oblong, $3^{\prime \prime}-6^{\prime \prime}$ apart; perigynia horizontally spreading, usually the lower ones dellexed.

Wet places. Oneida and Essex counties. June. July.

Var. angustata Bailey. Stems 3'-12' high, rery slender, wiry, erect, the setraccous or flat leares less than $\frac{1}{2}$ "wide; the $2-4$ spikelets $2^{\prime \prime}-3^{\prime \prime}$ apart, 2-6 flomered, the terminal erect or oblique; perigynia lanceolate, nerved, tapering into a long, slender bifid beak much longer than the scale. Eisily recognized by its spikelets. (C. stellulata var. angustata Curey).

In swamps and wet mearlows. Infrequent except in the northern part of the State where it is common in swamps and wet places. June, July.

\section{Carex interior Builey.}

Stems $8^{\prime}-20^{\prime}$ high, erect, rough near the spike; leares mostly shorter than the culm, $\frac{1}{2}-1^{\prime \prime}$ wide, sometimes inrolute when dry; spikes $3^{\prime \prime}-6^{\prime \prime}$ in length, greenish brown; spilielets $2-4$, contiguous, or $2^{\prime \prime}-3^{\prime \prime}$ distant, the terminal one plainly staminate at the base, 4-10 flowered, a little divergent at maturity; bracts scale-like or bristleform; perigynia widely spreading, small, orate, nerved on the upper side, thick and spongy at the round or subcordate baso, $\frac{3^{\prime \prime}}{4}-1^{\prime \prime}$ long, contracted into a slender rough-margined bifid beak, longer than the orate, acute or obtuse brown whitemargined scale.

Swamps and wet places. Common in the central counties of the State. June.

Var. capillacea Bailey. Slender, $6^{\prime}-10^{\prime}$ high, stems and leaves capillary; "perigynia broader and moro conspicuously nerved on both sides." In our specimens the two lower spike- 
lets aro often $3^{n}-4^{\prime \prime}$ apart, the perigynia nerveless or obscurely nerved on the upper surface only, and widely divergent at matur. ity, agreeing with a form occurring in West Albany and Junius, having slightly wider leaves ( $\frac{1}{2} "$ wide or less) which connects the variety and the type.

Low grounds along streams and shores. Long Island. Mray, June.

\section{Carex seorsa IIowe.}

Stems $1^{\circ}-2^{\circ}$ high, slender, erect, smooth; leares mostly a lit tle shorter than the culm, $1^{\prime \prime}-11_{2}^{\prime \prime}$ wide, rough-margined; spike 1'-21' long, erect, green; spikelets 4-6, 6-20 1 lowered, globular or oblong, $2^{\prime \prime}-21^{\prime \prime}$ long, the upper two approximate, the others scattered, the lowest $\frac{1}{2}-1^{\prime}$ distant from the next above, usually subtended by a bristle form bract, rarely by a leafy one $1 \frac{1}{2}$ ' long; the terminal spikelet pistillate at the apex, rarely wholly staminate; perigynia small, broadly ovate, nerred on both sides, contracted into a short, smooth-margined, bifid beak, much longer than the green and brown white-margined subacute scale.

Swampy woods and groves. MIay, June. Lansingburgh, Rens. selaer county. Ilowe. East Islip, Suffolk county, and near Rome, Oneida county. Peck.

This species grows in tufts and is separated from C. interior by its taller, stouter culms, its longer spikes, moro numerous and moro scattered spilielets, and by its smooth-beaked perigynia.

Spikelets 2-15 or more, approximate or more or less aggregated, ovate, obovoid, globular or clavate, sessile, erect or spreading, green, fulvous or silvery-green, whitisl or tawny; perigynia concaro-conrex, ovate, oborate or lanceolate, mostly nerved, prominently wing-margined, with a flat mostly rough-margined bifid beak.

Perigynia ovate-lancoolate, narrowly winged...... mirabilis.

Perigynia linear-lanceolate or uarrowly lanceolate..

Perigynia orbicular-ovate, broadly winged........

1 Spikelets in a deneo cluster partly concealed by long

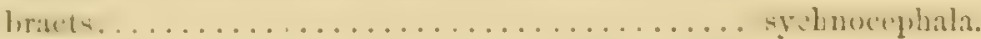

1 Spikuluts contiguous, bracts not concealing them ... 3

3 Spikelets densely aggregated, perigynia widely

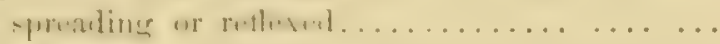

3 Spikelets contiguous or aggregated, perigynia not

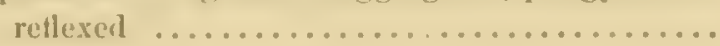

cristata. 
4 Spikelets 8-15 obovoid, tips of perigynia ascending. .

4 Spikelets $4-8$, ovate, acute, perigynia erect.......

tribuloides.

scoparia.

2 Spikes often drooping, spikelets green or fulvous, periggnia loose, ascending...............

straminea.

2 Spikes mostly erect, spikelets with a slight jellowish tinge, silvery.green, whitish or fulvous.....

5 Spikelets globose-ovate, acutish, perigynia erect... 5 Spikelets whitish, silvery-green or fulvuus........ 6 Spikelets obovoid, perigynia somewhat spreading. .

6 Spikelets $5 "-10^{\prime \prime}$ long, ovoid or clavate.........

7 Spikelets whitish, periggnia appresed ..........

7 Spikelets straw-colored, perigynia ascending ......

\section{Carex cristata sche.}

Stems $2^{\circ}-3^{\circ}$ high, stout, acutely angled, rough abovo the middle, prominently leafy; leares shorter or longer than the culm, their sheaths enlarged upward, $2^{\prime \prime}-3$ " wide, scabrous on the margins; spike $\frac{3^{\prime}}{1}-1 \frac{1}{2}$ in length, erect or oblique, cristate; spikelets 7-12 or more, globular, densely aggregrated, squarrose, the lowest with a setaceous or sometimes leafy bract 1'-2 $1^{\prime}$ long; perigynia elliptical-lanceolate, winged, nerred, tapering from the middlo to a rough-edged bidentate beak, recurved or spreading at maturity; scalo lanceolate, obtusish, brown, one-third shorter than the perigynium; achenium oral, short-stalked.

Fields and open woods, mostly in wet places. Common. July.

This fino species is at once linown by its squarroso globose spikelets and light green foliage. It is not very variable. It is regarded as a variety of $\mathrm{C}$. tribuloides in the Manual, but it is so constant and so peculiar in its appearance, being easily recognizable at sight, that it seems worthy of specific distinction.

\section{Carex tribuloides Wull.}

Stems $2^{\circ}-3^{\circ}$ high, firm, rough on the acute angles abore; leaves $1 \frac{1}{2}^{\prime \prime}-2 \frac{1}{2}^{\prime \prime}$ wide, their sheaths loose and wide abore, rough beneath or mostly on the margins, usually shorter than the culm; spikes $1^{\prime}-1 \frac{1^{\prime}}{2}$ long or more, erect, green; spikelets 8-15, aggregated or a little interrupted below, subglobose, the liwest with a setaceous or leafy bract $1^{\prime}-21^{\prime}$ in length; perigynia narrowly lanceolate, nerved, winged, $2^{\prime \prime}-2 \frac{1}{2}$ long, tapering from the middle to a long, rough-edged, bidentate 
beak, erect or spreading at maturity; scale lanceolate, obtuse, one-half as long as the perigynium; achenium oval, stalked.

Low moist ground and swales in fields or thin woods. Common. July.

Var. reducta Bailey. More slender than the typo; spike 1'-2' long, straight or flexuous, often nodding or recurved, somewhat erenly interrupted or moniliform ; spikelets $3-10,2^{\prime \prime}-2 \frac{1}{2}{ }^{\prime \prime}$ long, subglobose or obovate; bracts, when present, bristle-form; perigynia lanceolate, spreading, a little longer than the scale; achenium short-stalked or sessile.

Swamps or wet places in fields or the borders of woods. Common. july.

The spilielets are smaller than in the typical form of the species, and in general appearance the plant is quite distinct and probably worthy of specific distinction.

Var. Bebbii Bailey. Slender, erect; leares $11_{2}^{11}-2^{\prime \prime}$ wide, much shorter than the culm, their sheaths not enlarged above; spikelets $4-6$, oroid, 2 - $-2 \frac{1}{3}^{\prime \prime} \mathrm{long}$, aggregated into an oroid head $5^{\prime \prime}-6^{\prime \prime}$ long, greenish-brown or tawny; bracts usually present, bristleform; perigynia lanceolate, narrowly winged, erect-spreading, a little longer than the acute brown scale; achenium oral, sessile.

Wet places. Rensselaer and Cortland counties and in the northern part of the State. July.

This also might easily be regarded as a ralid species.

\section{Carex scoparia Schk.}

Stems $1 \frac{1}{2}^{\circ}-2 \frac{1}{2}^{\circ}$ high, slender, erect, rough at the top; leares shorter than the culm, $1^{\prime \prime}-1 \frac{1}{2}^{\prime \prime}$ wide, rough-margined; spilie ${ }^{3}-1{ }^{\prime}{ }^{\prime}$ in length, straight or a little flexuous, greenish brown or tawny ; spikelets $4-5$, oblong orate or elliptical, acute, the upper contiguous, tho others distinct, or often aggregated into an ovoid head, sub-erect; bracts usually early deciduous, leafy when present; perigynia narrowly lanceolate, nerved, winged, tapering to a pointed bitid beak, slightly spreading at maturity; scale lanceolate, acute, brown, about one-half the length of the perigynium; achenium narrowly oral, long-stallied.

Common in open fields and in ditches by roadsides. July.

This species is very easily distinguished by its orato acute brownish or tawny spilielets and appressed perigymia. 
Var. minor Boott. A much reduced form, $6^{\prime}-10^{\prime}$ high, the spikelets $2^{\prime \prime}-4^{\prime \prime}$ long and darker than in tho type. It of ten grows in drier places. Apparently an off-shoot of this is forna elation Peck, in litt. which is taller, the spikes da.ker, and the perigynia more spreading, a not unusual condition in the Adirondack specimens. A noticeable feature is the filiform bract, which subtends the lowest spikelet.

\section{Carex albolutescens Schno.}

Stems $1 \frac{1}{2}{ }^{\circ}-2^{\circ}$ high, erect or slender and recurred at tho summit; lerves $1^{\prime \prime}-1 \frac{1}{2}$ " wide, rough-margined, mostly shorter than the culn; ; silse $\frac{3}{4}-1 \frac{1}{2}$ in length, erect or subflexuous and drooping, light yellowish-green; spikelets $3-S$, approximate, oroid, obtuse or subacute, the terminal one conspicuously staminate and contracted at the base; the scales acute or cuspidato; bracts scale-like or bristle-shaped, that of the lowest spikelet $\frac{1^{\prime}}{2}-1 \frac{1}{2}^{\prime}$ long; perigynia broadly ovate, nerred on both sides, thin, erect, with a slightly rough-margined bifid beak, a little longer than the ovate pointed or cuspidato scale; achenium oral, short-stipitate.

The spikelets are sometimes globose and green rather than palo yellowish-green, but the species is well marked by its erect perigynia, sharply pointed scales and bristle-shaped bracts.(C. straminea var. focnea Torr. Gray's Man., 6th ed.)

Suffolk county. July.

Var. cumulata Bailey. Stems taller and leaves shorter; spiliolets 5-30, aggregated, abruptly contracted at base, spreading; perigynia obscurely nerved, appressed, otherwiso as in the typo.

Suffolk county. July.

\section{Carex fonea Willd.}

Stems $15^{\prime}-30^{\prime}$ high, slender, erect or recurved-spreading, smooth; leaves light green, $1^{\prime \prime}-1{ }^{\prime \prime}$ wide, smooth, shorter than the culm, spike $\frac{3^{\prime}-1}{4} \frac{1}{2}^{\prime}$ in length, recurved or flexuous, silvery or whitish green; spikelets $5-8$, the upper 2 or 3 contiguous, the others more or less separate, glubose or oborate, contracted at the base into a short or long slender stipe, the lowest sometimes with a colored bristle-tipped bract $\frac{1}{2}$ long; perigynia broadly ovate, prominently nerved on both sides, broadly winged above the middle, finely scabrous margined, with a short bidentato beak, somowhat loosely spreading when mature; scale ovate, 
acute, whitish or tawny, about the length of the perigynium; achenium ovate, apiculate.

A fine species, easily determined by the slender lax stems, and silvery-white, subsquarrose spikelets.

Woods and copses, especially in hilly and mountainous parts of the State. Common. June, July.

Var. perplexa Bailey. Larger, stouter, erect; the spilielets larger, the staminate portion less conspicuous, approximate, or agrgregated into an erect head, the lowest sometimes prominently bracteate, perigynia of a firmer texture.

A form occurs which has stiff, subflexuous spilies, silvery-green spikelets, orate above but narrowed below, and somewhat clubshaped; perigynia thin, spreading, about as long as the pointed scale.

Dry ground. Washington and Otsego counties. June, July.

Var. sparsiflora Olney. Differs from the type in its more slender culms, the spikes mostly nodding, and in its fewer, smaller and fewer-flowered spikelets.

\section{Carex silicea Olney.}

Stems $1^{\circ}-2^{\circ}$ high, firm, often recurred at the summit, mostly smooth; leares stiff, erect, flat or involute, rough beneath, as long as tho culm; spikes $11^{\prime}-3$ ' long, often flexuous; spikelets 4-8 or more, separate, moniliform, ovate, acute or obtuse, with a club-shaped base, silvery-white or tawny, $3^{\prime \prime}-5^{\prime \prime}$ long, erect or spreading; bracts scale-like, lanceolate, as long as the stipe-lilio baso; perigynia broadly ovate, nerred on both sides, wrinkled on the broad wing above, tapering into a short, smooth or ruughish bifid beak, about ecqual to or a little surpassing the orate, pointed scale; the tips of the perigy nia mostly appressed.

Sandy soil. Sulfolli county. July.

This species is abundant near the sea shore. Forms sometimes occur in which the spikelets are contiguous or the upper ones even agrgregated. Occasionally the lowest one is borne on a long peduncle or branch, and rarely it is compound.

\section{Carex straminea Wille.}

Stems $15^{\prime}-30^{\prime}$ high, erect or the summit drooping, smooth; leaves usually shorter than the culm, $1^{\prime \prime}-1 \frac{1}{2}$ " wide, smooth or rough-margined, yellowish green; spiko 1'-1' long, llexuous; 
spikelets $3-5$, contiguous or $3^{n}-4^{\prime \prime}$ apart, orate or subglobose above the contracted staminate base, $2^{\prime \prime}-2 \frac{1}{2}$ " wide, erect or ascending; bracts scale-like, pointed, or the lowest bristly shaped, rarely leaf-like; perigynia orate, faintly or conspicuously nerred on one or both sides, moderately winged, with a short or long bifid beak, the tips loosely spreading, a little longer than the orate acute tawny scale; achenium oral or oborate, apiculate-(C. tenera Dew., Wood's Cl. 13., C. straminea var. tenera Boot'., Gray's Man., 5th ed.)

$\Lambda$ common species in copses and open fields. June, July.

Var. brevior Dew. Every way larger than the type; spike stiff and erect; spiliclets approximate or separate, ovate or subglobose abore the staminate base, $3^{\prime \prime}-5^{\prime \prime}$ broad; perigg nia orbicular-orate, broadly winged, nerved, with a conspicuously short bifid beak, the points loosely spreading.

Var. festucacea Boott. Spilie erect, or slightly flexuous and recurred; spilielets $t-10$, club-shaped, the sterile portion usually exceeding tho fertile, $4^{\prime \prime}-6^{\prime \prime}$ long, the upper 3 or 4 contigucus, the others separate, forming an open or interrupted spike $1 \frac{1}{2}-3^{\prime}$ long, straw-colored or tawny.

Var. Crawei Boott. Differs from the last in its more robust habit, its weaker and sometimes drooping spikes, its larger globular spikelets, usually only the fighest with a conspicuously contracted base, and in its broader winged, longer beaked perigynia.

Saratoga county.

Var. aperta Boott. Resembles the typo in its slender habit and nodding spikes, but has larger spikelets all prominently tapering at the base, the perigynia more broadly winged, longer beaked, twice the length of the rusty brown scale.

Var. invisa $W^{\circ}$. Boott. Stems $1^{\circ}-2^{\circ}$ high, lax at the summit; leares as long as the culm, $1^{\prime \prime}$ wide or less; spike narrow, flexuous ; spikelets nggregated or separate, the lowest often distant or remote, $2 \frac{1}{2}{ }^{\prime \prime}-3^{\prime \prime}$ broad, rusty brown; bracts filiform, $2^{\prime}-5^{\prime}$ in length.

Sandy soil. Suflolk county.

\section{Carex alata Torr.}

Stems $11^{1}-3^{\circ}$ high, firm, erect, smooth belor; leares stiff, rough-margined, $1^{\prime \prime}-11^{\prime \prime}$ "wide, shorter than the culm; spike $1^{\prime}-1 \frac{1}{2}{ }^{\prime}$ long or more; spikelets $4-10, \pm^{\prime \prime}-6^{7}$ in length; orate or oborate, 
acute, contiguous or separate, greenish or straw-colored, sometimes tawny; perigynia orbicular-orate or oborate, cuneate or cordato at the base, nerred, broadly winged, with a short abrupt beak, longer and broader than the lanceolate, acute or roughawned scale - (C. straminea Willd. var. alata Bailey.)

Sirales and wet places. Suffolk and Seneca counties. July.

\section{Carex mirabilis Dero.}

Stems $15^{\prime}-36^{\prime}$ high, crect, smooth; leares about equaling the culm, $11^{\prime \prime}-2^{\prime \prime}$ wide, rough-elged; spike $1_{2}^{1^{\prime}}-2^{\prime}$ in length, erect, often flexuous; spikelets $1-11$, globose, contiguous, or the 2 or 3 lower ones sometimes $2^{\prime \prime}-3$ " apart, ascending or widely spreading, green becoming tawny or rusty when old; bracts scale-lilie, or the lowest usually short setaceous; perigynia orate-lanceolate, lightly nerved on both sides, narrowly winged, gradually tapering into a short or long rough-margined bilid beak, widely diverging when mature; scale narrowly orate, obtuse, much shorter than the perigynium; achenium oral, apiculate and stipitate.

Easily determined by its coarse, rigid aspect and squarrose spikelets. Common in copses and fields. June.

This is added to $\mathrm{C}$. straminea as a variety in tho last edition of the MIanual.

\section{Carex sychnocephala Carey.}

Stems $8^{\prime}-16^{\prime}$ high, erect, smooth; leaves $t^{\prime}-9^{\prime}$ in length, $1^{\prime \prime}-1 \frac{1}{2}^{\prime \prime}$ wide; spikelets $4-5$, densely aggregated in a head, $6^{\prime \prime}-9^{\prime \prime}$ long, $\left.3^{\prime \prime}-5\right)^{\prime \prime}$ wide, partly concealed by 3 leaf-like bracts $3^{\prime}-6^{\prime}$ in length; perigynia linear-lanceolate, $21^{\prime \prime}-3^{\prime \prime}$ long, pointed at the base. nerved, the long slender beak sharply toothed, twice the length of the blunt or mucronate scale.

Low wet mealows and moist places. Tery rare. June, July.

Collected about fifty years ago in Herkimer and Jefferson counties, but it does not appear to bare been found in our State recently.

Staminate flowers situated abore or below the pistillate or the middle spikelets sometimes wholly sterile or wholly fertile.

Spikelets oblong-lancenlate, perigynia linear-lanceolate.. bromoides.

Spikelets $4-8$, periggnia lanceolate............ siccata.

Spikelets 10-15 or more, perigynia ovate-lanceolate.... Sartwellii. 


\section{Carex Sartwellii Devo}

Stems $18^{\prime}-30^{\prime}$ high, erect, smooth; leares usually shorter than the culm, $1^{\prime \prime}-1 \frac{1}{2}{ }^{\prime \prime}$ wide, rough on the slender points; spike $1^{\prime}-2^{\prime}$ long, erect, brown; spikelets 12-20, contiguous or the lower $2^{\prime \prime}$ or $3^{\prime \prime}$ distant, orate, widely spreading; bracts scale-like, or the lower ones setaceous, $3^{\prime \prime}-6^{\prime \prime}$ long; perigynia orate-lanceolate, nerved, gradually tapering into a sbort, rough-edged, bifid beak, a little exceeding the orato acute brown scale, loosely spreading at maturity.

Bogs and swamps. Very rare. Seneca county. July.

The numerous spreading spikelets disposed in a rather compact spike distinguishes this species. It is C. disticha IIuds. in tho fifth edition of tho Manual.

\section{Carez siccata D.20.}

Stoloniferous; stems $15^{\prime}-30^{\prime}$ high, slonder, erect or spreading, smooth; leaves mostly shorter than the culm, about $1^{\prime \prime}$ wide, smooth; spikes $\frac{3}{4}-11^{\prime}$ long, brown, dry and chaffy; spikelets $7-16,4^{\prime \prime}-6^{\prime \prime}$ long, orate or elliptical, acuto or blunt at tho apex, mostly aggregated; bracts scalo.like, the lower lanceolato acuminate, sometimes rough-awned; perigynia lanceolate, nerved, with a long rough bifid beak scarcely spreading at maturity; scale broadly lanceolate, acute, brown, with broad whito margins above the middle.

A special feature of this species is the dry or orer-ripo appearance of the spikes.

Rich soil in open woods and copses, also on sandy plains. Rare in the western part of the State, but more common in the eastern and southern part. June, July.

\section{Carex bromoides $S c h k$.}

Stems $1^{\circ}-2^{\circ}$ high, slender, erect or sprealing, rough abore the middle; leares as long as the culm, or shorter, $\frac{1}{{ }^{\prime \prime}}-1^{n}$ wide, roughelged; spikes $\frac{3}{t}-1{ }^{\prime}$ ' long, of a clear light brown; spilielets $3-8$, the upper three usually contiguous, the lower ones more or less separate, the lowest sometimes subdistant, erect, cylindrical, $3^{\prime \prime}-9^{\prime \prime}$ in length; bracts scale-like, the lowest short-setaceous; perigynia linear-lanceolate, nerved, tapering below to a thick corky base, and above into a long slender rough edged bifid 
beak, much longer than the oblong-lanceolate or ovate acute brown scale, erect-spreading at maturity.

The conspicuously corly base of the perigynia distinguishes this species.

Wooded swamps, wet meadows, etc. Common. May, June.

Stigmas 3 ; achenium triangular.

Spikes staminate abore, pistillate belor.

F'lowers disposed in a single spike $2^{\prime \prime}-8^{\prime \prime}$ long.

Bracts and scales not leaf-lilie.

P'erigynia oblong, erect............... polytrichoides.

Perigynia awl-shaped, deflexed............. pauciflora.

35. Carex polytrichoides ITuh.

Stems $4^{\prime}-15^{\prime}$ high, capillary, diffuse or erect, rough abore; leaves flat or capillary, ${ }^{\prime \prime}$ wide, smooth and soft, mostly about the length of the culms; spike linear, $2^{\prime \prime}-5^{\prime \prime}$ long, subloosely flowered, green or brownish at maturity; bracts scale-like, orate, bristle-tipped; perigynia 1 $1 \frac{1}{2}$ long, subtriquetrous, alternate, erect, slightly recurved at the apex, nerved, about twice longer than the obtuse or acute, whitish scale, the latter usually caducous.

Swamps and wet places. Common. June.

The species is easily distinguished by the small green fewflowered spilies and caducous scales.

\section{Carex pauciflora Lightf.}

Stems $6^{\prime}-15^{n}$ high, stilf, erect or curved, smooth below; leaves flat or involute, $\frac{1}{2}$ "wide, rough-margined, stiff and often curved, mostly shorter than the culm; staminate scales 2, light brown, conspicuously terminating the spilie; spilie loosely 2-5 flowered; perigynia awl-shaped, $4^{\prime \prime}$ long, slightly inflated, mostly erect in the early stage, becoming widely divergent and strongly deflexed at maturity, twice the length of the lanceolate scale.

Cold sphagnous swamps and bogs. Common in the northern part of the State, rare elsewhere. June, July.

A pretty species, easily distinguished by its single spilie and subulate at length deflesed perigynia.

Bracts and scales leaf-like.

Porigrnia $2-i$, smonth . . . . . . . . . . . .

Perigynia 4-9, rough on the angles and beak....... Willdenovid.

Perigynia 2-5, rough on tho beak............. Jamesii. 


\section{Carex Backii Boott.}

Stems $\frac{1}{2}-4^{\prime}$ high, diffuse; leares $2-4$ times the length of the

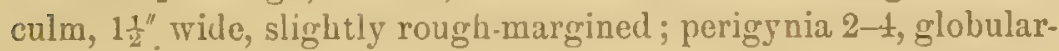
ovate, abruptly contracted into a long, smooth beak; scales leafy, mostly concealing the spike; staminato scales inconspicuous.

Woods. Local. June. Found many years ago in Jefferson county. The name has recently been changed to $\mathrm{C}$. durifolia Builey.

\section{Carex Willdenovii Schk.}

Stems $1^{\prime}-10^{\prime}$ high or more, slender, erect or diffuse; leares $1^{\prime \prime}-11^{\prime \prime}$ wide, far surpassing the culm, roughish on the margins; spike $2^{\prime \prime}-4^{\prime \prime}$ long, 49 flowered; perigynia globose-ovoid, rough on the angles and the awl-shaped beak; scales leaf-like below, the upper broadly lanceolate with a green 3 -nerved center and scarious marrins, usually exceeding the perigynia, staminate portion $2^{\prime \prime}-3^{\prime \prime}$ long.

Moist, shady places in woods and ravines. Rare. Jefferson and Cayuga counties. June. Sometimes one or two additional spikes are borne on subradical peduncles.

\section{Carex Jamesii Schro.}

Stems $3^{\prime}-10^{\prime}$ high, capillary, spreading or erect; leares mostly twice the length of the culm, $\frac{1}{2}{ }^{\prime \prime}-1 \frac{1}{2}$ " wide, rough on tho margins; spike conspicuous, loosely 2-5 flowered; perigynia globular, smooth, abruptly contracted into a long, rough.edged beak; scales leaf.like, mostly exceeding the culm; staminato portion $3^{\prime \prime}-5^{\prime \prime}$ long.

Woods and rarines. Very rare. Cayuga county. June. This is C. Steudelii Irunth.

B. Staminate and pistillate flowers disposed in separate spilies on the same culm or plant (monocecious), or on distinct culms or separato plants (dioccious).

Stigmas 2, rarely 3 ; achenium lenticular.

Plant commonly diocious.

\section{Carex gynocrates Wormsk.}

Stems $4^{\prime}-6^{\prime}$ high, erect, rough at the summit, as long as the capillary leaves; sterilo spiko linear, $6^{\prime \prime}$ long or less, fertile spikes

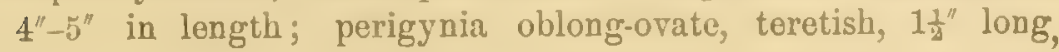


nerved, contracted into a short bifid or notched beak, longer than tho orate acute or pointed scale, horizontally spreading at maturity.

Swamps. Rare. June, July. Genesee, Wayne, Yates and Herkimer counties.

Var. substaminata Peck. (C. monosperma Macoun). This has a single perigynium at the base of the staminate spilie.

Plant monnecious.

Staminate spikes 1-3, stalked, often with a few fertile flowers at the base or apex; pistillate spikes 1-5, stalked or sessile, cylindrical, densely flowered or sometimes loosely flowered toward the base, often staminate at the apex; bracts leaf-like or tiliform, the lowest usually equaling or surpassing the culm, sheathless; perigynia compressed, orato or oborate (turgid in 47 and 48); scales dark purple or brown (sometimes greenish in 47 and 45 ), giving a mottled appearance to the spilies, mostly shorter than the perigynia.

Pistillate spikes erect or epreading (the lower ones recurved or drooping in 46), scales awnless ........

Pistillate suikes nodding, scales rough-awned ...............

1 Periggnia stalked, their scales blackish-purple or brown, 2

1 Perigynia sessile, their scales brown or purple-margined, 5

2 Perigynia nerved or nerveless, their scales blackishpurple ......................... rigida.

2 Perigynia nerveless, their scales brown.......... 3

3 Perigynia olovate, spikes $2^{\prime \prime}$ wide ............. aquatilis.

\& Perigynia ovate or elliptical, syikes less than $2^{\prime \prime}$ wide .. 4

4 Scales sharp pointed, squarrose............... aperta.

4 Scales obtuse, perigynia tortuous at the apex...... torta.

5 Perigynia nerveless...................... stricta.

5 Perigynia slightly nerved................... lenticularis.

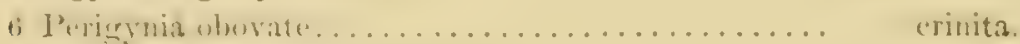

6 Perigynia ovate or oblong-ovate.............. gynandra.

\section{Carex rigida Good., var. Bigelovii Tüutm.}

Stems $10^{\prime}-15^{\prime}$ high, erect, smooth, sometimes stoloniferous; leaves shorter than, or as long as, the culm, smooth, usually $1^{\prime \prime}$ wide, erect, or the lower ones recurred-spreading, smooth; 
staminate spike linear, $3^{\prime \prime}-9^{\prime \prime}$ long, borne on a stalk $2^{\prime \prime}-10^{n}$ in length, light brown; pistillate spilies 2-3, approximate, the upper two sometimes contiguous and sessile, or the lower two stalled, the lowest sometimes borne on an erect or spreading peduncle $6^{\prime \prime}-9^{\prime \prime}$ long, subdensely or loosely flowered, often interrupted and tapering at base, $\frac{1}{x}-1 \frac{1}{x}$ in length; bracts short-setaceous, or the lowest sometimes exceeding the spike; perigynia elliptical, nerved or nerveless, whitish green, mostly covered by the blackishpurple elliptical scale.

It may be distinguished from the related species by its small size, blackish fertile spikes and by its alpino habit.

Summits of the higher peaks of the Adirondack mountains, especially Mit. W'hiteface and Mt. Marcy.

In the fifth edition of Gray's MIanual, Carey describes a very different plant under the abore name.

\section{Carex lenticularis $1 / x$.}

Stems $10^{\prime}-20^{\prime}$ high, slender, erect or somewhat spreading, mostly smooth; leaves usually shorter than the culm, $\frac{1}{2} "-1$ " wide, rough-margined; staminate spike cylindrical, sometimes bearing a few perigynia, $3^{\prime \prime}-12^{\prime \prime}$ long, its stalk $2^{\prime \prime}-8^{\prime \prime}$ in length, brown, erect; pistillato spikes $3-4,6^{\prime \prime}-12^{\prime \prime}$ long, approximate or contiguous, sometimes the lowest distant, short-peduncled or sessile, erect or ascending, densely flowered abore, more or less loosely flowered and tapering at the baso; bracts leaf-like, usually surpassing the culm; perigynia ovate, stipitate, lightly nerved, the upper third sometimes conspicuously empty and a littlo recurved, minutely pointed, one-third longer than the blunt, green and brown scale.

Well marked by its densely flowered, nearly aggregated, grayish green spikes, and by the usually empty points of the perigynia.

Gravelly shores of lakes and streams. Adirondack mountains. July.

Var. merens Ilowe, n. var. Ditfers from tho preceding in its longer, narrower, darker colored fertile spikes, the lowest usually short-pedunculate; in its longer, wider bracts, $1 \frac{1}{2}-2 \frac{1}{2}$ longer than the culm; in its elliptical perigynia, and in its longer scale which nearly covers the perigynium. 
43. Carex aquatilis Wahl.

Stems $2^{\circ}-3^{\circ}$ high, firm, erect, acutely triangular abore, smooth; leaves long, sometimes surpassing the culm, $1 \frac{1}{2} "-2^{\prime \prime}$ wide, roughmargined, pale green or glaucous; staminate spikes $1-4$, the highest on a short stalk, $1^{\prime}-11^{\prime}$ in length, the others shorter and sessile; usually 1 or more with a setaceous or filiform bract; pistillate spikes $3-5$, sessile or the lowest short-peduncled, approximate or subdistant, or the lowest remote, cylindrical or subclarate, the upper often staminate at the apex, ${ }^{\prime}{ }^{\prime}-2^{\prime} l o n g$, compactly flowered; bracts leafy, much surpassing the culm; perigynia broadly orate or elliptical, nerveless, biconrex, minutely pointed or pointless, about the length of the narror, obtuse, brown scale.

Cold upland stramps and wet places. Not common. June, July.

\section{Carex aperta Boott.}

Stems $20^{\prime}-30^{\prime}$ high, erect, triangular, rough abore the middle; leares about $11^{\prime \prime}$ wide, rough-margined, shorter than the culm; staminate spikes 1-2, cylindrical, the highest $1^{\prime}-11^{\prime}$ long, shortstalked, the other shorter and sessile, usually with a setaceous bract; pistillate spikes $2-t$, cylindrical, the upper approximate and sessile, sometimes sterile at the apex, the lowest distant, short-peduncled, often staminate abore, $y^{\prime \prime}-15^{\prime \prime}$ long, densely flowered above, more loosely at the tapering base; upper bract bristle-shaped, longer than the spilie, tho lowest leafy, mostly shorter than the culm; perigynia orate, stipitate, nerreless, olire-brown, minutely dotted, with a small notched point, more or less spreading at maturity; scalo dark brown, narrowly lanceolate, pointed, horizontally spreading, exceeding the perigynia.

Rare. Essex county. July.

This is Carex stricta rar. decora Bailey in tho 6th edition of tho Minual.

\section{Carex stricta $L a m$.}

Stems $2^{\circ}-3^{\circ}$ high, erect, acutely triangular, rough above the middle; basal sheaths with fibrilloso margins, the fibrils either reticulated or parallel; leaves $1^{\prime \prime}-1 \frac{1}{2}$ " wide, rough margined, more or lessinvoluto when dry, glaucous-green, mosily shorter than the culm; staminato spilios $1-3, \frac{y^{\prime}}{2}-1 \frac{1}{3}^{\prime}$ long, tho highest on a stalk 
$1^{\prime}-1^{\prime}$ in length, the others smaller and sessile, usually with a scalelike or short setaceous bract; pistillate spikes $2-5, x^{\prime}-2^{\prime}$ long, the upper approximate, sessile, the lower subdistant or remote, short peduncled, erect or spreading, cylindrical or clavate, densely flowered abore the middle, more loosely at the usually tapering base, often barren at the summit; bracts of the upperspilies short setaceous, of the lower ones leafy, and mostly shorter than the culm; perigynia orate or elliptical, usually with two or three short nerves at the base, minutely pointed, of a creamy white color, often dashed with dark purple or sometimes wholly blackish purple; scale narrowly oblong, obtuse, reddish or dark brown, about the length of the perigynium, or sometimes longer.

A common species in wet places. May, June. It almost always grows in tufts. It is quite variable.

Var. strictior Curey. Pistillato spilies 2-3, approximate, or the lowest subdistant, densely flowered; perigynia ovate, bright green, about the length of the acute rusty-brown scale.

Var. xerocarpa S. Il. I'right. Slender; pistillate spikes 2-3, linear, more narrow than in the type, on filiform erect-spreading or drooping peduncles $\frac{1}{2}-1^{\prime}$ long; perigynia lenticular; scales mostly green with rusty brown points. A graceful rariety about one-half smaller than the typo.

Var. angustata Bailey. Pistillate spikes cylindrical, strict, 2'-3' long, densely flowered; scales moro acute, dark-brown or rust colored, often exceeding tho perigynium.

Var. curtissima Peck n. var. Stems $1 S^{\prime}-2 t^{\prime}$ high, rery slender, erect, rough, exceeding the narrow (1 ${ }^{\prime \prime}$ wicle) rough leares; staminate spike with a minute ono at its base, linear-clarate, $S^{\prime \prime}-10^{\prime \prime}$ long, short-stalked; pistillate spikes 2, oroid or oblong, densely thowered, sterile at the apex, $3^{\prime \prime}-6^{\prime \prime}$ long, $S^{\prime \prime}-10^{\prime \prime}$ apart, sessile; the lowest bract leaf-like, $1^{\prime}-1 \frac{1}{3}$ in length, the uppermost setaceous; perigynia oral with a minute orifice, longer than the blunt brown scalo.

\section{Carex torta Boott.}

Stems $15^{\prime}-30^{\prime}$ high, erect or spreading, acutely angled, mostly smooth; basal sheaths short, brown, fibrillose, leares $11^{\prime \prime}-6^{\prime}$ or more $\log g, 1 \frac{1}{2}-2^{\prime \prime}$ wide; staminate spikes $1-2$, cylindrical, $\frac{1}{2}-1 \frac{1}{2}$ long, the terminal one short or long-stalked, the lorrest sessile ; pistillate spikes $2-5, \frac{8}{4}-2 \frac{x^{\prime}}{2}$ long, cylindrical, densely flow- 
ered, or sometimes loosely flowered toward the base, often sterile at the apex, approximate, or subdistant, or even remote, the uppermost sometimes erect, the others spreading, recurved or drooping, all sessile or the lorrest on short, slender peduncles; bracts leafy or filiform, the lowest about equaling the culm, the others shorter or longer than their respective spikes; perigynia lanceolate, thin, deep-green or olive-colored, nerreless, oblique and tortuous or recurred at the empty apex; scale narrowly oblong obtuse or acute, a little shorter than the perigynium.

Wet places, especially along streams. Common. June.

\section{Carex crinita Lam.}

Stems $2^{\circ}-4^{\circ}$ high, stout, acutely angled, rough abore; sheaths smootb, fibrillose at the base; leares mostly shorter than the culm, $2^{\prime \prime}-t^{\prime \prime}$ wide, hispid beneath and on the margins; staminate spilies $1-3, \frac{1^{\prime}}{2}-3^{\prime}$ in length, the longest on filiform stalks $\frac{1^{\prime}}{2}-1^{\prime}$ long, more or less recurred, or eren pendulous; pistillate spikes 3-5, 2'-1' long, cylindrical, curred, densely flowered, or loosely flowered and tapering at the base, sometimes staminate at the apex, approximate, all on filiform stalks $\frac{1^{\prime}}{4}-1 \frac{1}{2}^{\prime}$ long, recurved-spreading or pendulous; lower bracts leafy, surpassing the culm, the upper short, filiform, longer or shorter than the spikes; perigynia round-obovate, stipitate, a little inflated, thin, faintly nerved or nerveless, with a conspicuous entire point; scale brown, oblong, obtuse, with a rough, green awn, twice the length of the perigynium.

Common in swamps, ditches and wet fields. June, July.

$\Lambda$ tall, robust, coarse-looking species, distinguished by its long, recurved or pendulous bristly fertilo spilies.

Var. minor boott. This is every way smaller; fertilo spikes more compactly fruited, usually shorter peduncled, the upper less drooping; scales with less conspicuous awns; plant paler and of tiner aspect.

\section{Carex gynandra Scho.}

Stems $2^{\circ}-4^{\circ}$ high, stout or slender, erect, rough on the angles and sheaths, those at the base fibrillose; leaves shorter or longer than the culm, 2 " $-4^{\prime \prime}$ wide, hispid beneath and on the margins; staminate spikes $1-3$, cylindrical, the terminal one on a filiform, curving peduncle $1^{\prime}$ long, the others short-stallied or subsessile, 
each with a scale-like or bristle-form bract; fertile spikes 3-6, subdensely flowered, ' 2 ' $\Psi^{\prime}$ 'long tapering at the base, usually one or more sterile at the apex, all short-peduncled and recurved or drooping, the lower subtended by foliaceous bracts longer than the culm, the upper bracts filiform or setaceous and shorter than the stem; perigynia oblong-orate, subinflated, nerveless or obscurely nerved, with a distinct entire point; scale oblong, obtuse or lanceolate, with a long rough awn, twice or thrice the length of the perigynium.

Separated from the last, to which it is closely related, by its hispid sheaths, soft fertilo spikes, and by its orato or oblongovate perigynia. Both species of ten grow together and in both the staminate spiko often bears a few perigynia.

\section{Stigmas 3 ; achenium triangular.}

Staminate spiko single (sometimes 2 or 3 in 44 ); fertilo spikes 1-t, on slender drooping stalks; perigynia compressed-triangular with a for indistinct nerves: scales dark purple or brown.

Perigynia oval or oblong•ovate, scale ovate, blunt or acute ............................ litturalis.

Perigynia ovate, scale ovate-mucronate.......... limosa.

Perigynia orbicular-ovate or obovate, scale slender

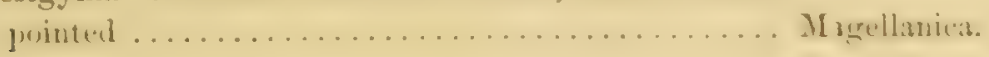

\section{Carex littoralis Schw.}

Stem 15'-21' high, slender, erect, acutely angled, smooth; leaves much shorter than the culm, $1^{\prime \prime}-11^{\prime \prime}$ wide, stiff and erect, smooth; staminato spike (rarely 2 or 3 ) subclarate, $6^{\prime \prime}-15^{\prime \prime}$ long, short-stalked, scales brown or blackish-purple; pistillate spikes 2-1, densely flowered, cylindrical, all usually staminate at the apex, subapproximate, the uppermost short-peduncled and suberect, the others on filiform drooping stalks $4^{\prime \prime}-9^{\prime \prime}$ long; bracts sheathless, the upper setaceous or scale-like, the lower leaf-like, shorter than the culm; perigynia compressed-oral, or oblongovate, lightly few-nerred, with a minute entire orifice, about the length of the obtuso or acute dark purplo scale.

Wet placos. Suffolk county. May.

This species has not before been credited to our State. In the Manual, New Jersey is given as its northern limit. It is doubt- 
ful if it will be found north of Long Island and Staten Island. Our specimens were collected near Islip.

It is C. Barrattii, Schu. and Torr., in the 5th edition of the Manual.

\section{Carex limosa $I$.}

Stoloniferous; stems $1^{\circ}-2^{\circ}$ high, slender, erect, acutely angled, rough aboro the middle; leares $\frac{1}{2}^{\prime \prime}-1^{\circ}$ wide, thick, sometimes involute, rough-marcrined, shorter than the culm; staminate spike solitary, linear, $\frac{1}{2}^{\prime}-1 \frac{1}{\frac{1}{x}}$ in length, usually equaling its peduncle; pistillate spikes 1-3, approximate or subdistant, oblong or oroid on recurred or drooping stalks $1_{2}^{\prime}-1^{\prime}$ long, 10-20 subloosely flowered, often barren at the summit, $\frac{1}{2}^{\prime}-1^{\prime} \operatorname{long}, \mathbf{1}^{\prime \prime}-3^{\prime \prime}$ wide; bracts slender-setaceous, shorter than the culm; perigynia orate or elliptical, nerved, light green, with a minute, entire point; scale lustrous brown, ovate, acuto or obtuse, sometimes cuspidate, as long and wide as the perigynium.

Cold swamps and bogs. Rare except in the central and northern parts of the State. July.

It bears some resemblance to $\mathrm{C}$. castanea, but that species has pubescent leaves and lanceolate perigynia.

Var. radicalis Paine. Staminate spike terminal on the naked, erect stout culm; pistillate spike single, drooping, on a filiform radical peduncle $4^{\prime}-9^{\prime}$ long. Ilerkimer county. Paine.

\section{Carex Magellanica Lam.}

Stems $10^{\prime}-20^{\prime}$ high, slender, erect, a little rough on the angles above; leaves mostly shorter than the culm, $1^{\prime \prime}-11^{1 . "}$ tvide, erect, rough on the margins; staminate spilise single, subclarate, long, its peduncle tiliform and drooping; pistillate spilies $2-4,1$ in length, 10-21 subloosely flowered, approximate, all on filiform drooping stalks '-1' long; bracts leaf-like, tho 2 lower usually surpassing tho culm; perigynia orato or elliptical, lightly nerved, pale green, with a minute entiro point, one-half the length of the lanceolate, pointed, dark purple scale, the latter a little dirergent at maturity

Cold sphagnous swamps, often in company with C. limosa. July.

This handsome species may bo identitied by its short, mostly pendulous mottled spikes with long-pointed, dark-purple scales. 
Spikes 2-4, oblong, oroid or cylindrical, densely florrered, erect, $2^{\prime \prime}-5^{\prime \prime}$ broad or more, $1^{\prime}-1^{\prime}$ long, the upper half or more of the terminal one fertile, staminate and stalk-like at the base, the others all fertile or nearly so; bracts leaf-lilie, the lowest shorter or longer than the culm.

Spikes brown.......................... fusca.

Spikes green, perigynia pubescent ............... virescens.

Spikes green, perigynia smooth ............... triceps.

\section{Carex fusca All.}

Stems $15^{\prime}-30^{\prime}$ high, erect, or sometimes curred at the summit, acutely angled, rough abore; leares subradical, 1" wide, shorter than the culm, rough-margined; spikes $2-t$, the terminal one staminate at the base, all approximate, or somerhat scattered, sessile, erect, the upper ones with filiform or bristle-form bracts, the lowest short-peduncled or sometimes on a spreading stalli 1 ' long and subtended by a leafy bract 1'-5' long, mostly densely flowered, oblong-oroid or cylindrical, $3 "-12$ " in length or more, $2 \frac{1}{3}^{\prime \prime}-6^{\prime \prime}$ thick, dark-brown or mottled; perigynia elliptical, prominently nerved, light green, with a minute, entire or slightly notched point, shorter than the lanceolate, cuspidate, dark-brown scale, the latter more or less divergent at maturity. (C. Buxbaumii Ifalil.)

Bogs and wet places. Albany, Essex, Genesee and Seneca counties. June, July.

The slender, mostly naked culms, and the short thick erect dark-colored or mottled spikes sulliciently distinguish this species.

\section{Carex triceps $\mathbf{I} x$.}

Stems $12^{\prime}-20^{\prime}$ high, stiff, scabrous abore; leares about the length of the culm, $1^{\prime \prime}-1 \frac{1}{2}$ " wide, erect, more or less pubescent, the sheaths densely hairy, pale-rreen; spikes $3-4$, the terminal stami. nate at its base, all contiguous, sessile or nearly so, erect, ovate, ovoid or oblong, $3^{\prime \prime}-8^{\prime \prime}$ long, $2^{\prime \prime}-3^{\prime \prime}$ thick, densely flowered; bracts leafy or filiform, the lowest, and sometimes all, exceeding the culm, perigynia orate, obtuse, nerred, smooth or hairy before maturity, longer than the orate, acute, short-anned, variable scale.

Dry'soil in pastures copses and thin woods. Common. June. 
This species is easily distinguished by its three or four short thick erect contiguous spikes, at first palegreen but turning brownish when old.

\section{Carex virescens Muhl.}

Stems $12^{\prime}-30^{\prime}$ high, slender, erect or sometimes spreading, rough near the summit; leares pubescent, $1^{\prime \prime}-1 \frac{1}{2}$ " wide, mostly tapering to a long filiform point, often equaling the culm; spikes $2-5$, the highest staminate at the base, all approximate or contiguous, oroid or oblong, $4^{\prime \prime}-12^{\prime \prime}$ in length, about $2^{\prime \prime}$ thick, compactly flowered, all on sbort stalks, the lowest sometimes spreading; bracts leafy or filiform, the lowest exceeding the culm; perigynia ovate, prominently nerved, scabrous-pubescent, longer than, or equaling the ovate, mucronate scale.

Similar to C. triceps in its place of growth and time of maturity. It is separated from it by the narrower and often longer spikes, and by its hairy perigynia.

Var. costata Dew. Stems $20^{\prime}-30^{\prime}$ high, spikes cylindrical, erect or slightly spreading; perigynia strongly nerved or ribbed. Equally common with the type.

Terminal spike pistillate at the summit, staminate below; fertile spikes 3-5, linear or cylindrical, on short, erect or long filiform peduncles, approximate, or the lowest sometimes distant, subdensely or loosely llowered; perigynia oblong with a short, notched point, or obtuse and pointless.

Spikes narrowly cylindrical, less than $2^{\prime \prime}$ wide........ 1

Spikes broadly cylindrical, $2^{p}$ wide .............. 2

1 Spikes loosely flowered, perigynia acute........... rstivalis.

1 Spikes densely tlowered, perigynia obtuse............ gracillima.

2 Scale shorter than the perigynium............. formosa.

2 Scale as long as the perigynium.............. Davisii.

55. Carex æstivalis M. A. Curtis.

Stems $1^{\circ}-2^{\circ}$ high, slender, erect or spreading, rough abore the middle ; leaves mostly shorter than the culm, $1^{\prime \prime}-1 \frac{1}{2}$ " wide, sparsely hairy, bright green, sheaths pubescent; staminate spilio fertile at the summit, linear or clavate; pistillate spilies $3-4$, linear, erect or spreading, the upper 2 or 3 approximate, the uppermost sometimes sessile at the base of the staminate, tho others short-stalked, 
the lowest often distant or remote on a filiform spreading peduncle 1 '-2' long, loosely flowered; bracts leafy or filiform, the lowest surpassing the culm; perigynia small, 1 "wide, orate, acutish at each end, nerred, entire at the apex, twice longer than the ovate, hyaline scale; achenium obovate, substipitate.

Shaded soil in woods. Rare. July. Otsego county. This delicate carex is distinguished from its near relatires by its slender, loosely-flowered, erect or spreading spilies and its hairy sheaths.

\section{Carex gracillima Schwo}

Stems $18^{\prime}-30^{\prime}$ high, erect, mostly smooth; basal sheaths prominently fibrillose; leares shorter than the culm, 1"-y" wide, radical leaves tufted, $2^{\prime \prime}-3 \frac{1}{2}$ "wide, rough, light green; staminate spilie with or without pistillate flowers at the apex, linear; pistillate spilies $3-4$, linear, the upper 2 or 3 approximate, the lowest distant, all drooping on filiform peduncles, subdensely flowered, or loosely flowered at the base; bracts leafy or filiform, the lowest as long as the culm; perigynia ovate, nerved, entire at the obtuse apex; seale orate, obtuse, hyaline, one-half as long as the perigynium; achenium oblong-oborate, apiculate.

Woods and fields in moist or dry soil. Tery common. June.

Tery rarely the lower spilies hare 1 or more additional branches at the base.

This species is well marked by tho blackish purple, fibrillose basal sheaths, and tho obtuse perigynia of the linear, subdensely. Hlowered, drooping spilies.

Var. humulis Bailcy. A much reduced form with 2-12 flowered spikes and smaller perigynia.

\section{C. gracillima $\times$ pubescens Horce.}

Stems 15'-30' high, stilf, rough; leaves $11^{\prime \prime}-21^{\prime \prime}$ wide, roughish and sometimes hairy, shorter than the culm; spilies approximate or the lowest distant, sessile or stalked, erect; perigynia oroid, hairy with a short bilentate beak, not unlike an abortire perigynium of $\mathrm{C}$. pubescens. (Botanical Gazette, Feb., 18s1, p. 169.) (C. Sullivantii Boott.)

In a swampy meadow. Yonkers, Westchester county. 1878.

A similar hybrid, but one more closely resembling C. gracillima, occurs in Albany and Greene csunties, where it was detected by Mr. C. L. Shear. 
The terminal spike bears perigynia at its apex; the perigynia are smooth and the scalo is acute or barely mucronate, not awned. In these respects it approaches $\mathrm{C}$. gracillima more closely than it does C. pubescens. 'This has been somewhat doubtfully considered by Professor Bailey to be a hybrid between C. gracillima $x$ astivalis, but it is only necessary to suppose that in this case the prepotency lies with $\mathrm{C}$, gracillima and in the other with C. pubescens to make both forms descendants of the same parent plants, as they probably are.

\section{Carex formosa Dew.}

Stems $15^{\prime}-30^{\prime}$ high, slender, erect, smooth; learos short, the uppermost sometimes equaling the culm, $1 \frac{1}{2} "-21$ " wide, slightly hispidly pubescent beneath, yellowish green; spikes $2-5$, the terminal with 6-8 perigynia at the apex, staminate below, long peduncled, the others subdistant or approximate, secund, all on filiform recursed or drooping peduncles, subdensely llowered, with 2 or 3 empty scales at the base; bracts leafy or filiform, about equaling the culm; perigynia orate, turgid, nerred, thin, tapering to a short entire or minutely-notched beak; scale ovate, obtuse, cuspidate, white or brownish, one-half as long as the perigynium.

The spilies are $1^{\prime}-1^{\prime} \operatorname{long}$, and about $2^{\prime \prime}$ wide; the perigynium $3^{\prime \prime}$ long and $1^{\prime \prime}$ wide, giving to the former a thick and heary appearance, by which the species may be distinguished.

Woods and wet places. Rare. June. Columbia, Oneida and Yates counties.

\section{Carex Davisii Schto. \& Torr.}

Stems $12^{\circ}-3^{\circ}$ high, erect, rather stout, smooth or with a soft pubescence; leaves mostly equaling or exceeding the culm, $11^{\prime \prime}-t^{\prime \prime}$ wide or more, clothed with a soft pubescenco beneath, hispid on the reins and margins; spilies $3-5$, the terminal, pistillate above, erect, the 2 upper fertile ones contignous at the base of the staminate portion, subsessile or short-peduncled, the lowest distant or remote on a short, erect, or rarely long, spreading stille $\frac{1^{\prime}}{y^{\prime}}-1 \frac{1}{z^{\prime}}$ long, densely flowered, $3^{\prime \prime}-t^{\prime \prime}$ wide, light green, erect or somewhat spreading; bracts leaf-like, equaling or excoeding tho culm; perigynia orate, conspicuously nerved, turgid, tapering into a short bifid beak, about the length of the orato obtuse awned scale. 
Wet meadors. Not common. June. Oneida corinty.

The drooping of the lower spikes depends on the splitting of the long sheaths which, for a time at least, include their short peduncles. This species is conspicuously marked by its short, thick, mostly erect spikes and large turgid perigynia.

Staminate spike club-shaped, long-peduncled; fertile spilies 24 , subapproximate or mostly remote, erect; bracts shorter than the culm; perigynia oblong, ovate or obovate, bakless except in 60 .

Upper spikes appproximate or nearly so.......... I

Upper spikes not approximate ................ 2

1 Periggnia oblong, lightly nerved or nerveless ........ livida.

1 Perigynia with impressed nerves ............... conoidea.

2 Sheathe dilated . . . . . . . . . . . . . . . . . . . .

2 Sheaths not dilated.......................

3 Leaves and bracts $1^{\prime \prime}$ wide, shorter than the culm....... tetanica.

3 Leaves and bracts $1^{\prime \prime}-1 \frac{1}{2}$ "wide, nearly equaling tho culm . Crawei.

59. Carex Crawei Dew.

Stoloniferous; stems $6^{\prime}-12^{\prime}$ high, slender, erect or diffuse, smooth; leares short, sometimes equaling the culm, $1^{\prime \prime}-1 \frac{1}{3}$ " wide, smooth, rough-margined; staminato spike clavate $\frac{I^{\prime}}{2}-1^{\prime}$ in leugth on a stiff, erect stalk 1'-2' long, sometimes with 1 or moro short additional ones at or near its base, and sometimes with a few fertilo llowers at the apex; pistillate spikes 2-4, cylindrical, densely flowered, $6^{\prime \prime}-9^{\prime \prime}$ long, distant or remote, sometimes the lowest subradical on a short exserted stalk; bracts leafy, sheathing, about equaling the culm; perigynia orate, lightly nerved, slightly turgid, roughish, tapering to a small entiro point, longer than the orate, cuspidate scale.

Limestone soil. Rare. June, July. Genesee, Herkimer and Jefferson counties.

Distinguished by its low stature, creeping root-stock, and densely flowered distant dull brown nearly sessile spiles.

\section{Carex livida Willd.}

Stems 6'-18' high, slender, erect, smooth; leaves mostly shorter than the culm, $\frac{1}{2}^{\prime \prime}-1^{\prime \prime}$ wide, flat or in rolute, stiff, rough margined; staminate spike cylindrical, acute, $\frac{1}{2}^{\prime}-1^{\prime}$ in length, on a stiff stalk $\frac{1^{\prime}}{2}-1^{\prime}$ long; pistillate spilies 1-2, contiguous, rarely a third sub- 
radical one, short oblong or cylindrical, $\frac{1}{4}-\frac{3}{4}$ long, 15-20 loosely flowered, sessile; bracts small, leafy or setaceous, scarcely equaling the culm; perigynia oroid-oblong, lightly nerred, pale green, tapering to a small, straight, entire point, a little exceeding the ovate, light brown scale.

Cold swamps. Very rare. June, July. Oneida and Herkimer counties.

\section{Carex vaginata Tuusch.}

Stoloniferous ; stems $10^{\prime}-2 t^{\prime}$ high, mostly weak and diffuse, smooth; leares subradical, half the length of the culm, $11^{\prime \prime}-2^{\prime \prime}$ wide, smooth, slightly rough on the margin, radical leares tufted, nearly as long as the culm, $2^{\prime \prime}-3^{\prime \prime}$ wide ; staminate spilie clarate, or oroidoblong and acute, erect or oblique, $\frac{1^{\prime}}{2}-3^{\prime}$ long, its stalk $\frac{3^{\prime}}{4}-1 \frac{1}{2}^{\prime}$ in leggth, or more; pistillate spikes 2 or 3, remote, 4-10 loosely or 12-15 compactly flowered, $\frac{1^{\prime}}{1}-\frac{1}{2}$ ' or more long, on exserted, filiform erect or drooping peduncles ${ }^{\prime}-11^{\prime}$ in length, the latter partly included in the conspicuously dilated sheaths of the short leafy bracts; perigynia oblong-ovate, nerved, tapering to a short round oblique-notebed beak, longer than the ovate acute or obtusish thin brown scale.

Swampy places. Very rare or local. June. Genesee county.

This rare species is conspicuously marked by its dilated sheaths and round-beaked perigynia. It stands under the name C. Saltuensis Bailey in the sixth edition of the Manual.

\section{Carex tetanica Schk.}

Stoloniferous; stems $1^{\circ}-2^{\circ}$ high, slender, erect, rough at the summit; leaves mostly shorter than the culm; $\frac{1}{2}^{\prime \prime}-1^{\prime \prime}$ wide, stiff, flat or involute above, roughish on the margins, bright green or glaucous; staminate spike clavate or cylindrical $1_{z}^{\prime}-1^{\prime}$ in length, on a slender, mostly erect pedunclo $2{ }^{\prime}-t^{\prime}$ long, light brown; pistillate spikes 1-3, remote, loosely flowered, cylindrical, usually with a tapering base, ${ }^{\prime}-1$ ' in length; the uppermost shortstallied or nearly sessile, the lower on slender, erect or spreading peduncles 1'-31.' long; bracts folinceous, much shorter than tho culm; perigynia triangular-oboroid, prominently nerved, abruptly contracted into a short curved entire point, longer than the ovate obtuse, sometimes mucronate or cuspidate thin white and brown scalo; achenium shortobovate, tricostate, with a short, bent style. 
Wet swampy places. Rare. June. Cayuga, Seneca and Jefferson counties.

This is distinguished from its congeners by the long.peduncled spikes and obovoia, nerved perigynia.

Var. Woodii Bxiley is a lax form growing in deep shade and having longer spreading leaves and shorter fower flowered fertile spikes.

\section{Carex conoidea Schk.}

Stems $12^{\prime}-20^{\prime}$ high, stiff, rough abore; leares mostly shorter than the culm, $1^{\prime \prime}$ wide, rough margined; staminate spilie $\frac{1}{2}^{\prime}-1^{\prime}$ long, clavate, long or short-peduncled, erect, light brown; pistillate spikes $1-3,6^{\prime \prime}-9^{\prime \prime}$ long, subdensely flowered, the upper 2 approximate or distant, short stalked or sessile, the lowest remote on a spreading or erect peduncle $\frac{1^{\prime}}{2}-1 \frac{1}{2}^{\prime}$ long; bracts foliaceous, usually shorter than the culm; perigynia oblong-conic with impressed nerves, and a short straight or curred entire point, about the length of the orate rough-awned scale, the latter more or less divergent at maturity; achenium obovate, apiculate.

Moist meadows and grassy places. Common. June.

This is easily recognized by the shape and nerving of the perigynia.

Fertile spikes 2-6, erect on exserted stalks or the uppermost sessile, approximato or tho lower distant; bracts leaf-like, exceeding the culm; perigynia oblong or pyriform, obtuse, nerved (obscurely in $6 \pm$ and 65).

Periggnia obscurely nerved.................. 1

Perigynia distinctly nerved ................. 2

1 Perigynia ol long..................... pallesecns.

1 Perigynia pyriform..................... aurea.

2 Perigynia oblong.ovate, $11^{\prime \prime}$ long............... glaucodea.

2 Perigyuia oblong, $2^{\prime \prime}$ long ................. grisea.

\section{Carex pallescens $L$.}

Stems 6'-24' high, slender, mostly erect, hispid on the angles near the spilies, smooth below; leares mostly shorter than the culm, $1^{\prime \prime}-11^{\prime \prime}$ wide, rough-margined, slightly pubescent on the sheaths ; staminate spike often clavate, $4^{\prime \prime}-S^{\prime \prime}$ long, short-stalked; pistillate spikes $2-4$, oblong, densely flowered, $3^{\prime \prime}-6^{\mathrm{h}}$ long, con- 
tiguous, the uppermost sessile, the otbers on short peduncles, erect or spreading; bracts leafy, sheathless, often transversely wrinkled at the base, exceeding the culm; perigynia oblong, faintly nerred, pointless, as long as the pointed scale.

Fields and grassy places. Common. June.

The species is well marked by the somewhat clustered, shortpeduncled, fertile spikes, and the oblong obscurely-nerved pointless perigynia.

\section{Carex aurea Nutt.}

Stems $3^{\prime}-18^{\prime}$ high, slender, erect or subprocumbent, smooth below, roughish abore; leares mostly shorter than the culm (or exceeding it in pigmy forms) $1_{2}^{\prime \prime}-1^{\prime \prime}$ wide, smooth, slightly rough on the margins, bright green; staminate spike clavate, $3^{\prime \prime}-S^{\prime \prime}$ long, sessile and inconspicuous, or stalled and manifest; pistillate spikes 2-4, cylindrical, $3^{\prime \prime}-9^{\prime \prime}$ long, the upper 2 contiguous, sessile or subsessile, erect or slightly spreading, the lower subdistant, on slender peduncles - $^{\prime}-1^{*}$ in length, suberect or spreading, sometimes a subradical spilie is present on a long, suberect pedunclo ; bracts leaf-like, sheathing, exceeding the culm; perigynia oroid or pyriform, nervel, thick, yellowish or golden brown at maturity, obtuse at the apex, longer than tho ovate, acute or mucronate scale; stigmas 2 or 3 , acheniun lenticular, apiculate.

Wet springy ground and banks of streams. June, July.

This interesting and infrequent species may bo distinguished by its small pyriform yellowish-brown perigynia and lenticular achenia.

\section{Carex glaucodea Tickm.}

Stems 6 '-20' high, erect or spreading, smooth; leares mostly subradical, usually shorter than the culm, $1 \frac{1}{2}-4^{\prime \prime}$ wide, rough at the extremities, smooth on the lower half, glaucous or pale green; staminate spike subclavate, $6^{\prime \prime}-9^{\prime \prime}$ long, sessile, sometimes inconspicuous; pistillate spilies $2-1$, subdensely flowored, perfectly cylindrical, $y^{\prime}-1^{\prime}$ long, the upper 2 usually approximate, the lower on erest, exserted stalks $\frac{1^{\prime}}{2}-1^{\prime}$ in length, or the lowest remoto on a filiform spreading or recurred peduncle $2-5$ 'long, glaucous, turning to a dull brown; bracts liko tho leaves, sheathing, all but tho lowest excecling tho culm; perigynia oblong ovate, numerously finoly nerved, of a thick or loathery texture, tapering to an acutish, entire or notched apex, about twico longer than tho 
ovate, acute or cuspidate scale; achenium oborate; style even (not tumid), curred or abruptly bent at the base.

Thin woods and moist places. Rare. June, July. Cayuga and Dutchess counties.

This species may be separated from C. grisea, which it resem. bles, by its shorter stems and leaves, its more cylindrical spikes, and shorter perigynia, and by its curved styles.

\section{Carex grisea Wahl.}

Stems $1^{\circ}-2 \frac{1}{2}^{\circ}$ high, firm, usually somewhat robust, smooth, or sometimes roughish at the summit; leares slightly hispid on the upper surface, smooth beneath, $1 \frac{1}{2}^{\prime \prime}-3^{\prime \prime}$ wide, the highest exceeding the culm, pale green ; staminate spilie $3^{\prime \prime}-9^{\prime \prime}$ long, sessile; pistillate spikes $2-4$, oblong, thick, loosely or subloosely flowered, $\frac{1}{4}^{\prime} \cdots 1^{\prime}$ in length, the upper 2 usually contiguous, the uppermost sessile, the others more or less distant on stiff, erect peduncles $1^{\prime}-1^{\prime}$ long, light green or fading to tawny; bracts leafy, sheathing, erectspreading, or the upper divergent, much longer than the culm; perigynia oblong, obtuse, turgid, finely nerred, about the length of the ovate, cuspidate or rough-arned scale; achenium obovate, sometimes apiculate, with a straight, tumid or bulbous-thickened style.

Moist ground and grassy places. Common. Juno.

This species frequently forms tufts. Its straight, tumid or bulbous-thickened style articulates at or slightly abore its base. A slender narrow.leaved form occurs which closely approaches, and which perhaps is referable to Var. angustifolia Boott.

Leaves and bracts alike, sheathing, conspicuously thin, the latter exceeding the culm; perigynia oboroid or ovate-triquetrous, finely striate or nerved, distinctly beaked, shorter than the trinerved, pointed or rough-awned scale.

Spikes 3-8 flowered, sheaths smooth........... oligocarpa. Spikes 3-10 flowered, sheaths pubescent ......... Hitchcockiana.

\section{- 68. Carex oligocarpa Schk.}

Stems $6^{\prime}-18^{\prime}$ high, slender, erect or somewhat diffuse, rough on the upper portion; leaves short, or sometimes equaling the culm, about $1^{\prime \prime}$ wide, slightly rough on the veins beneath and margins; 
staminate spike linear or subclarate, subsessile or on a stalk $\frac{1^{\prime}}{2}-1^{\prime}$ in length; pistillate spikes $2-4$, the upper 1 or 2 contiguous or distinct, short-pedunculate or sessile, the others distant or remote on stallis $\frac{1}{2}^{\prime}-1 \frac{1}{2}^{\prime}$ long, all erect, loosely $3-8$ flowered on a flexuous rachis; bracts with smooth sheaths, thin, longer than the culm; perigynia obovoid-triangular, with a distinct straight or slightly oblique beak, shorter than the rough pointed or awned scale; achenium obovate, apiculate; style tumid abore the minute persistent base.

Woods and shady places. Rare in the eastern part of the State, occasional elsewhere. June.

This species is distinguished by its thin, narrow foliage, fer and loosely flowered spilies, nearly straight-beaked striate perigynia, and tri-nerved awned scale.

\section{Carex Hitchcockiana Dero.}

Stems $1^{\circ}-z^{\circ}$ high or more, erect or spreading, rough, or smooth below; leaves short, or the upper equaliug the culm, 1'-1 $1^{\prime}$ wide, thin, more or less hispidly pubescent; staminate spike linear or subclarate, $\frac{x^{\prime}}{2}-1^{\prime}$ in length, on a slender, erect peduncle $\frac{1^{\prime}}{1}-1 \frac{1}{y^{\prime}}$ long; pistillate spikes $2-t$, loosely $3-10$ flowered on a llexuous rachis, the upper two approximate, mostly on included stalks or the highest sessile, the lower distant or remote on erect, slightlyexserted peduncles; bracts and sheatbs roughly pubescent, the former mostly surpassing the culm; perigynia oval or obovate, obtusely triangular, striate-nerved, $2^{\prime \prime}$ long, with an abrupt or tapering oblique recurved truncato beak, a little shorter than the broad trinerved rough-awned white scale; achenium and style like the last.

Woods. Rare in the eastern part of the State. June, July

This may be distinguished from the preceding species by its pubescent sheaths, rougher foliage, shorter-stemmed fertile spikes, and by its perigynia, which hare a conspicuously oblique or recurved beak.

Tar. trillora l'eck n. var. More slender, with the fertile spikes 1-3 llowered.

Collected on MIt. Defiance. June.

I'istillate spilies 2-6, moro or less flexuous, the upper 2 contiguous or approximate, sessilo or nearly so, tho rest scattered 
and stalked, or sometimes all subdistant; bracts mostly exceeding the culm; perigynia obtusely angled, prominently nerred and having an abruptly bent or recurved rarely straight beak.

Isower or radical leaves $8^{\prime \prime}$ broad or more......... albursina.

Lower leaves less than $8^{\prime \prime}$ broad ................. I

1 Pistillate spikes densely flowered, periggnia ovate.... granularis.

1 Pistillate spikes subdensely or loosely flowered....... 2

2 Upper spikes usually contiguous, the sterile subsessile, blanda.

2 Upper spikes rarely contiguous, the sterile stalked.. 3

3 Spikes subloosely thowered, brects shorter than the culm, styloflexa.

3 Spikes loosely flowered, bracts longer than the culm. laxiflora.

70. Carex laxiflora Irom.

Stems $1^{\circ}-2^{\circ}$ high, erect or spreading, triangular, smooth; leaves mostly subradical, short, $1 \frac{1}{2}{ }^{\prime \prime}-4^{\prime \prime}$ wide, smooth except on the margins, the radical often wider and half as long as the culm; staminate spike linear or clavate, $\frac{1^{\prime}}{2}-1^{\prime}$ long, conspicuously stalked or subsessile; pistillate spikes $2-4$, linear, loosely flowered on a flexuous rachis $\frac{1}{4}^{\prime}-1^{\prime}$ in length, the uppermost (rarely 2) sessilo or short-stalked at the base of the sterile, the others subdistant or the lowest remote, all on erect, exserted peduncles $\frac{1}{4}-1 \frac{1}{2}^{\prime}$ long; bracts leafy, short-sheathed, shorter or slightly longer than the culm; perigynia obovate, strongly nerred, with a straight or slightly recurved beak, exceeding the orate, obtuse, mostly mucro. nate white scale.

A subradical spike on a slender, flattened pedunclo $2^{\prime}-2^{\prime} \frac{1}{3}^{\prime}$ in length is not rare.

Woods, ravines and open places. Common. June.

Var. varians Bailey has stouter culms and broader leares than the type, the fertile spikes a little closer flowered, the upper 2 mostly contiguous to the sterile, the highest sessile, bracts often longer than the culm, the perigynia less strongly nerred.

Var. patulifolia Carey differs from the type chiefly in its broader root leaves, $5^{\prime \prime}-\tau^{\prime \prime}$ wide, and in the usually longer bracts, equaling or surpassing the culm.

Very common in damp shades and rarines. May, Jane.

71. Carex styloflexa Buckley.

Stems $12^{\prime}-18^{\prime}$ high, slender, erect or diffuse, smooth, leaves $2^{\prime}-4^{\prime}$ long, $1^{\prime \prime}$ wide, the radical longer and $1^{\prime \prime}-1 \frac{1}{2}$ " wide; staminate 
spike about $y^{\prime}$ long on a slender, smooth stalk $\frac{1}{2}^{\prime}-\frac{8}{2}^{\prime}$ in length; scales oblong, blunt, light brown; pistillate spikes 2-4, $\frac{1^{\prime}}{4} \cdot \frac{1}{2}^{\prime}$ in length, 5-10 subloosely flowered, scattered, all but the highest stalked, the lorrest usually on a filiform recurred peduncle; bracts mostly shorter than the culm; perigynia oborate, lightly nerved, with a straight or recurred beak, longer than the orate acute brown scale.

Grassy places. Rare. June. Albany and Cattaraugus courties.

This has been regarded by some as a variety of the preceding species, but it is easily separated by its short spikes.

\section{Carex blanda Dero.}

Stems $8^{\prime}-20^{\prime}$ high, erect, triquetrous, rough on the angles; leaves $1 \frac{1}{2}^{\prime \prime}-3^{\circ}$ wide, rough abore the middle, equaling or shorter than the culm; staminate spilke clarate, $4^{\prime \prime}-9^{\prime \prime}$ long, sessile or on a stalk $\frac{1}{4}^{\prime}-1^{\prime}$ long; pistillate spikes $3-4,3^{\prime \prime}-9^{\prime \prime}$ long, subdensely flowered, the upper 2 usually contiguous to the staminate spike and sessile or nearly so, the lower pedunculate, erect, or the lowest remoto on a setaceous peduncle $2^{\prime}-3^{\prime}$ long, suberect or recurved; bracts leafy, mostly exceeding the culm; perigynia oborate, with a long or short tapering base, prominently nerved, terminating in a short recurved or abruptly bent beak, longer than the ovate, acute or mucronate white scale, more or less diverging at maturity.

Woods and fields. Very common June.

Rarely among the large forms 1 or 2 of the lower spikes are compressed; occasionally there is but 1 spilie, stalked or sessile and contiguous to the staminate, in which case the latter is usually long-peduncled, exceeding the bracts. This species has been considered by some as a rariety of C. laxiflora to which it is joined in the Manual, but its short dense pistillate spikes and commonly short sessile staminate spilie givo it such a distinct aspect that it may be distinguished at a glance.

\section{Carex albursina sheld.}

Stems $12^{\prime}-20^{\prime}$ high, erect or spreading, llaccid below, acutely triangular and somowhat winged abore, smooth; stem leares $2^{\prime}-6^{\prime}$ long, $11^{\prime \prime}-3^{\prime \prime}$ wide, the radical longer, $8^{\prime \prime}-15^{\prime \prime}$ broad, smooth ; staminate spike linear, $3^{\prime \prime}-15^{\prime \prime}$ in length, mostly sessile and often 
inconspicuous ; pistillate spikes cylindrical, loosely flowered on a slightly flexuous rachis $\frac{1^{\prime}}{2}-1^{\prime}$ long, the upper 1 or 2 contiguous to the staminate and sessile or nearly so, the lorvest on a filiform peduncle 1'-2' long, all erect or slightly spreading; bracts leafy, $2^{\prime \prime}-4^{\prime \prime}$ broad, acuminate, the lowest much exceeding the culm; perigynia oroid-elliptical or obovate, nerred, $1 \frac{1{ }^{\prime \prime}}{2}-2^{\prime \prime}$ long, half as broad, with a short recurved beak, twice the length of the obtuse mucronate white scale.

Rich moist soil in woods and shaded places. Not common. June. Albany, Cayuga and Jefferson counties.

This species was separated from C. laxiflora, to which it was formerly joined as Var. latifolia Boott, because of its broad leaves and bracts and its short sessile staminate spilie. Its large perigynia also confirm the validity of its separation.

The fruit of this and the three precedng species shells easily, and the specimens should be collected while it is yet scarcely mature.

\section{Carex granularis Muhl.}

Stems $10^{\prime}-24^{\prime}$ high, mostly erect, smooth; leaves short, usually much shorter than the culm, $1^{\prime \prime}-4^{\prime \prime}$ wide, smooth, rough near the apex, sheaths prominently glaucous; staminate spiko subclavate,

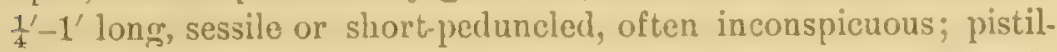
late spilies $2-5$, cylindrical, compactly flowered, $\frac{1^{\prime}}{4}-1^{\prime}$ in length, the upper 2 mostly contiguous to the staminate spike, sessile or slightly stalked, the others more or less distant on exserted peduncles $\frac{1^{\prime}}{x^{\prime}}-2^{\prime}$ long, erect or the lowest spreading, or rarely on a filiform drooping stalk $3^{\prime}$ long; bracts leafy, rough, the low er sheathing, exceeding the culm; perigynia romud-ovate or oblongconical, prominently nerred, slightly turgid with a short bent entire or notched apex, nearly twice longer than the ovate pointed thin white scale; achenium oborate, minutely dotted, tipped with tho abruptly bent style.

Wet or moist ground in meadows and grassy places. Common. June.

It is distinguished by the dense, cylindrical fertile spikes, and the strongly-nerved perigynia.

Var. recta Devo. is usually smaller, the spikes less densely flowered, the perigynia with a straight acute or acuminate point. 
Staminato spike clavate, pedunculate; pistillate spikes $\mathbf{2}-\mathbf{4}$, short-cylindrical, 3-9 loosely or subloosely flowered, all on exserted erect or spreading filiform stalks, the lowest often sub. radical or even radical; bracts leafy, sheathed, shorter or longer than the culm; perigynia acutely triangular, finely and closely nerved, with a short recurved or sometimes obsolete point; scale thin, white or brown.

I'istill ate spikes pendulous; leaves $2^{\prime \prime}-5^{\prime \prime}$ broad ..... laxiculmis. Pistillate spikes erect-spreading, leaves $1^{\prime \prime}-1 \frac{1}{2}$ " broad... digitalis.

\section{Carex digitalis Willd.}

Stems $6^{\prime}-1 S^{\prime}$ high, slender, almost capillary, erect or at length spreading, smooth; leares about the length of the culm $1^{\prime \prime}-1 \frac{1}{2}{ }^{\prime \prime}$ wide, rough-margined, bright green; staminate spike $6 "-9^{\prime \prime}$ long, its stalk $\frac{1}{2}-2 \frac{1}{2}$ in length; pistillate spikes $2-4$, loosely $6-9$ flowered, the highest subsessile or long-peduncled, the lower subdistant or remote on filiform spreading peduncles $1^{\prime}-2 \frac{1}{2}$ in length or more, the lowest sometimes pendulous; bracts leafy, sheathing, equaling or exceeding the culm; perigynia triangular-elliptical, finely nerved, with a short, obliquely bent point, nearly twice longer than the acute white scale.

Woods and rarines. Not rery common. June.

Tho species is known by its narrow, 3-reined leares and the small triangular perigynia. It usually grows in tufts.

\section{Carex laxiculmis Scho.}

Stems $10^{\prime}-20^{\prime}$ high, slender, suberect or prostrate, smooth; leaves mostly shorter than the culm, $1 \frac{1}{2}-5^{\prime \prime}$ wide, conspicuously 3-veined, glaucous, rough on the margins; staminate spike clavate, $6^{\prime \prime}-10^{\prime \prime}$ long, sometimes subtended by a slender green bract $2^{\prime \prime}-5^{\prime \prime}$ in length, mostly long-peduncled, exceeding the leaflike sheathing bracts; pistillato spikes $3^{\prime \prime}-6$ " long, densely 3-8llowered, all except the subsessile highest one on drooping filiform peduncles $1 \frac{1}{2}-21^{\prime}$ long; perigynia triquetrous, elliptical, densely nerved, with a short oblique or curved point, exceeding the orate, obtuse or pointed brown or whico scale. (C. retro curva Dero.)

'Thin wouds and copses. Common. June. 
The broad glaucous leares and drooping spilies on long filiform peduncles characterize this species.

There is a lato form (Forma serotina) in which the ner growth develops fruit soon after the old fruit has matured. In it the siaminate spike is inconspicuous or abortire, and the pistillate spilies are erect and on peduncles much shorter than usual.

Staminate spilies clavate; pistillate $2-5$, erect, mostly on included stalks; bracts about the length of their long sheaths-or obsolete; perigynia acutely angled, finely nerred (obscurely in 80) with a short recurved or straight beak; leares radical, prominently 3-ribbed (narrow and 1-veined in 50 ).

Leaves narrow, 1-veined ................... pedunculata.

Leaves 3 -ribbed, bracts conspicuous ............ 1

Bracts obsolete, sheaths purple .............. plantaginea.

1 Leaves $2^{\prime \prime}-5^{\prime \prime}$ broad, dark green ............... Careyana.

1 Leaves $3^{\prime \prime}-12^{\prime \prime}$ broad, whitish-green ............. platyphylla.

\section{Carex Careyana Torr.}

Stems $1^{\circ}-2^{\circ}$ high, erect-spreading, smooth; leares rough boneath or smooth throughout, $2^{\prime \prime}-5$ " wide, shorter than the culm, dark green; staminato spilio clarate, $5^{\prime \prime}-10^{\prime \prime}$ in length, its stalk $1^{\prime}-1^{\prime}$ long, usually with a scale-like or slender green bract, seales purplish or brown; pistillate spikes 2-3, loosely 2-S flowered, the uppermost sessilo at the base of the sterile, the other's scattered, sometimes the lowest remote on a partly included stalk $1^{\prime}-1 \frac{1^{\prime}}{2}$ long; bracts leafy, as long as their sheaths; perigynia acutely triangular-ovate, $2^{\prime \prime}-21^{\prime \prime}$ long, closely nerred, with an oblique or recurred beak, twice the length of the orate, acute or mucronate purple-brown scale.

Woods and ravines. Rare. Mray. Cayuga, Genesee and Jefferson counties.

\section{Carex platyphylla Carey.}

Stems $S^{\prime}-15^{\prime}$ high, slender, erect, at length widely spreading, smooth; leaves shorter than the culm or rarely exceeding it, ${ }^{1}{ }^{\prime}-1^{\prime}$ broad, smooth, glaucous or whitish green; staminate spilie $4^{\prime \prime}-10^{\prime \prime}$ long, its peduncle $\frac{1}{4}^{\prime}-1^{\prime}$ in length or rarely subsessile, usually with a scale-like or bristle-shaped bract; pistillate spiles 2-3, 2-10 loosely flowered, scattered, all erect on included stalls; 
bracts leafy, about twice the length of the spikes; perigynia oroid, acutely angled, closely nerred, with a recurved, entire or

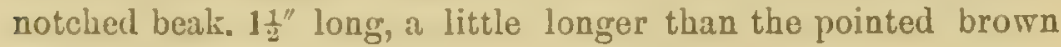
scalc.

Woods, hillsides and ravines. Common. June.

This species is easily recognized by its broad pale or glaucous leares, conspicuous leaf-like bracts and short, loose, ferv.florered spilies.

\section{Carex plantaginea Lam.}

Stems $1^{\circ}-2^{\circ}$ high, slender, erect, at length spreading or prostrate, smooth; basal bracts $4-7$, acute, dark purple; learps shorter than the culm, $\frac{1^{\prime}}{2}-1^{\prime}$ broad or more, smooth, prominently 3-ribbed; staminate spike subclarate, acute at each end, $\frac{1}{2}^{\prime}$ in length, its stalk $5^{\prime \prime}-15^{\prime \prime}$ long, with dark purple scales; pistillate spikes $34,3-10$ loosely flowered, $\frac{1}{6}-\frac{8^{\prime}}{4}$ long, distant, erect on included peduncles, or the lowest subradical on an exserted stalk $1^{\prime}-9^{\prime}$ in length; bracts $2^{\prime \prime}-4^{\prime \prime}$ long, acuminate or bristle-tipped, purple, with dark purple sheaths $\frac{1^{\prime}}{4}-1^{\prime}$ long or more; perigynia triangular ovate, finely nerved, with a short recurred beak, $2^{\prime \prime}-22^{\prime \prime}$ long, a lit.le exceeding the ovate, acute, purple-pointed scale.

Shaded banlis, hillsides, copses and open moods. Infrequent. May, June.

This is a rery distinct species, recognizable at a glance by its broad radical leaves and its purplish sheaths, bracts and scales.

\section{Carex pedunculata Muhl.}

Stems 3'-12' long, slender, diffuse, smooth; basal bracts purple with acute green points; leares flat, $1^{\prime \prime}-11^{2}$ " wide, rough beneath, stiff, longer than the culm; staminate spike cylindrical or oroid, sessile, obtuse or acute, $2^{\prime \prime}-3^{\prime \prime}$ long, with dark purple scales; fertile spilies $2-4,3-8$ subdensely flowered, slightly staminate at the apex, $2^{\prime \prime}-t^{\prime \prime}$ in length, the uppermost sessile at the base of the sterile spilie, the others subdistant on stalks $1^{\prime}-1^{\prime}$ long, suberect or spreading, radical spikes numerous, prostrate on filiform peduncles $2^{\prime}-6^{\prime}$ long; bracts inconspicuous, green, about the length of tho sheaths; perigynia triangular-obosate, minutoly downy or smooth, with a long tapering base and a short recurred minutely notched beak, smaller than the broadly obovate awned or cuspidato purplish scalo. 
Woods and banks. Common. May, June.

This species is characterized by its commonly prostrate growth, inconspicuous bracts and concealed fruit.

It inbabits chiefly dry shaded situations, but is found in meadows, on banks, and amongst shrubbery in rocky places.

Pistillate spikes $3-t$, few flowered, on erect or drooping partly included stalks; bracts obsolete or as long as their respective sheaths; perigynia minute, oblong, obscurely nerred, with a bent or straight, beak; olive-brown at maturity; leaves short, setaceous or about $1^{\prime \prime}$ wide.

Lesves subradical, not setaceous................ capillaris.

Leaves radical, setace ons.................. eburnea.

\section{Carex capillaris $L$.}

Stems capillary, $4^{\prime}-12^{\prime}$ high, erect, smooth; leares shorter than the culm, $1^{\prime \prime}$ wide or less, rough on the margins, the radical ones numerous, flat, soft, often involuto when old; staminato spike clavate, $2^{\prime \prime}-3^{\prime \prime}$ long, its stalk $3^{\prime \prime}-9^{\prime \prime}$ in length; pistillate spikes 2-3, scattered, the uppermost usualiy erect and equaling the staminate spike, the lower on drooping pedunsles $3^{\prime \prime}-12^{\prime \prime}$ long; bracts leaflike, as long as their respective sheaths or more, the lowest usually exceeding its spike; perigynia oblong, $1^{\prime \prime}-11^{\prime \prime}$ in length, nerveless, 2-ribbed, slightly turgid, somewhat thin in texture, olive brown, with a slender, entire roughish beak about twice the length of the orite obtuse brown scale; achenium narrowly oboroid.

Wet places. Local. Cortland county.

82. Garex eburnea lBoott.

Stoloniferous: stems 5 ' $-12^{\prime}$ high, capillary, but firm and erect, smooth; leares bristle-shaped, recurvel-spreading, rough abore the middle, shorter than the culm; staminate spilie linear, $3^{\prime \prime}-5^{\prime \prime}$ long, sessile or slightly peduncled between the more elevated and conspicuous pistillate spikes, acute at each end, the brown scales often partly conceuled by the scarious sheaths; pistillate spikes 2-4, 2-6 densely flowered, $1^{\prime \prime}-2^{\prime \prime}$ long, approximate on slender stalks $4^{\prime \prime}-8^{\prime \prime}$ in length, sometimes the lowest distant; sheaths scarious, white with a tinge of brown at the base; perigynia 
triangular obovate, obscurely nerved, smooth, olire-brown, shining, with a minute round beak, longer than the ovate obtuse or acutish light-brown scale.

Thin soil on or about limestone ledges. June.

A very small species, but one easily known by its setaceous leares and its very small erect pistillate spikes surpassing the staminate one.

Plant diocious; staminate and pistillate spikes of the same size and color; bracts, when present, scale-like or setaceous, sheathless; perigynia dark purple, densely hairy, with a short, entire beak; scales blackish purple.

\section{Carex scirpoidea $M x$.}

Stoloniferous; stems $6^{\prime}-15^{\prime}$ high, slender, erect, smooth; basal bracts dark purple, acute or obtuse; leares subradical, stiff, mostly much shorter than the culm, $1^{\prime \prime}$ wide, smooth; staminate spike subclavate, $\frac{1}{2}-1^{\prime}$ in length with a small greenish tri-nerved cuspiclate bract and dark purple scales; pistillate spikes $\underline{x}^{\prime}-1^{\prime}$ long, densely flowered; bracts setaceous, sheathless; perigynia orate, rery hairy, gradually tapering to a short entire or notched beak, mostly corered by the acutish blackish-purple ciliate scale.

Thin soil covering rocks. Adirondack mountains. July.

Plant monocious; staminato spike cla rate, sessile or short-stalked; pistillate spikes 1-5, globular-ovoid, oblong or cylindrical, sessile or short-stallied, the upper 2 contiguous or approximate, or all distinct and the lowest subdistant, each subtended by a scalc-like or green bract, the lowest often by a leafy one $\frac{1^{\prime}}{2}-2 y^{\prime}$ long; perigynia subrotund, oval or elliptical, obtusely or acutely angled, mostly densely pubescent, abruptly contracted into a slender bifid beak; scale orate, commonly brown or purplish, equaling or shorter than the perigynia.

Plant pubescent ..................... pubescens.

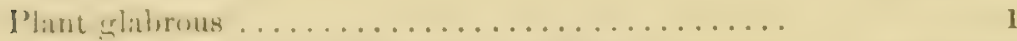

1 Pistillate spikes on short stems, umbellately clustered, umbellata.

1 Pistillate spikes not umbellately clustered......... 2

2 Bracts sheathing, purplish .............. Richardsonii.

2 Bracts not sheathing.................... 3

3 Staminate spike $3^{\prime \prime}$ long or less . ............. 4

3 Staminate spike more than $3^{\prime \prime}$ long............. 6 
4 Culms weak, recurved or reclining ............

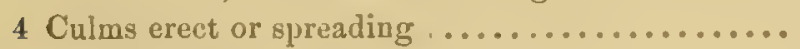

Peckii.

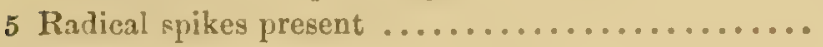

deflexa.

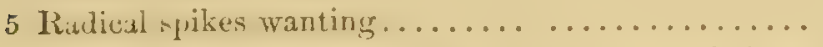

Emmonsii.

6 Staminate spike about $\frac{1}{2}$ " wide, the lowest pistillate suike with a long slender green bract.......... Novæ-Anglix.

6 Staminate spike more than $\frac{1}{2}$ wide............

7 Plant stoloniferous, scales of pistillate spikes commonly brown or purplish ................ Pennsylvanica.

7 Plant not stoloniferous, scales of pistillate spikes commonly greenish or tawny.............. varia.

84. Carex umbellata Schk.

Stems $2^{\prime}-4^{\prime}$ high, erect, growing in dense tufts from strong fibrous roots, somewhat stoloniferous; leaves $2^{\prime}-10^{\prime}$ long, about $\mathbf{1}^{\prime \prime}$ wide, flat, or sometimes involute, rough, stiff, erect or spreading ; staminate spike clavate, $1^{\prime}-\frac{1}{2}$ ' in length, rarely with a pistillate spike at its base; pistillate spikes in clusters of 2 or 3 on stems $\frac{1^{\prime}}{2} \cdot 2^{\prime}$ long; usually lerel topped, 3 -8 flowered; perigynia oroid or triangular-obovate, nerreless, lightly pubescent, green or turning to brownish with age, with an abrupt flattisb bidentate beak, usually covered by the ovato pointed scale.

Dry or sandy soil and rocky places. Common. Mray, June.

The umbel-like clusters of pistillate spilies suggest the name of this species. They are often half concealed by the leares.

Var. vicina Dew. A form with 1 or 2 fertile spilses at the base of the sterile spilie.

It is found with the typical form.

\section{Carex Pennsylvanica Lam.}

Stoloniferous; stems $6^{\prime}-18^{\prime}$ high, slender, erect or spreading, rough or smooth, basal sheaths purplish or dull bromn, tibrillose; leares mostly about the length of the culm but sometimes exceeding it, $\frac{1}{2}^{\prime \prime}-1 \frac{1}{2}$ " wide, rough-margined, bright or dull green, erect or diffuse; staminate spike club shaped, $5^{\prime \prime}-9^{\prime \prime}$ long, usually sessile, scales oblong obtuse or pointed, brown, or blackish brown; pistillate spikes $1-1$, usually 3 , globular or oblong, densely or loosely flowered, the upper 2 contiguous, sessile, the lowest $2^{\prime \prime}-6^{\prime \prime}$ distant, sessile or slightly stalked, bracts scale-like acute or 
bristle-tipped, or sometimes the lowest leaf-like and 9 "-18" in length; perigynia subrotund or obovate, obtusely angled, densely or lightly pubescent, indistinctly nerved, abruptly contracted at the base, and narrowel above into a short bifid bexk, covered by the ovato acute or acuminate, dark purplish or light brown scale.

Dryish soil in woods, copses or open places. Very common. May, Juno.

Var. separans Peck. Pistillate spikes 1-3, usually 2, the uppermost approximate to the short-stalked dark-brown sterile spike, the lowest 5" $-10^{\prime \prime}$ distant; perigynia with a longer and more slender beak; otherwise like the typo (Var. distans, Report 46, p. 51).

Along or within the borders of woods. Jefferson and Otsego counties. June.

Var. gracilifolia Peck, n. nom. Leaves long and slender, $\frac{1}{2}=-\frac{2}{8}$ wide, sometimes slightly involute and almost capillary, about equaling or sometimes considerably surpassing the slender culm. (Var. angustifolia l.c.)

Light or sandy soil in woods or open places. It often grows in tufts. 'This variety is common on Long Island. May.

Because of the frequent previous use of the varietal name under which this plant was published it is thought best to give it a new name.

Var. glumabunda Peck, n. var. Stems $8^{\prime}-18^{\prime}$ bigh, rather weak and often sornewhat drooping, frequently growing in definito tufts; pistillate spikes mostly short and sessile as in tho type, but sometimes the lorrest $3^{\prime \prime}-8^{\prime \prime}$ long, conspicuously slalked or on a capillary peduncle $2^{\prime}-S^{\prime}$ long which issues from the axil of the uppormost leaf, the others near tho staminate spilio and contiguous to each other or the lower sometimes $4^{\prime \prime}-6^{\prime \prime}$ distant, these occasionally sterile and acute at the apex; scales conspicu. ously brown or blackish brorwn, oblong-ovate or lanceolate, sharppointed or cuspidate, longer than tho perigynia and widely spreading at maturity. (Forma paleacea in part, l.c.)

Sandy soil. Albany and Suffolk counties.

Very rarely a second long-peduncled spike issues from the axil of one of the lower leaves. In all these varieties the bract of the lowest sessile spike is sometimes longer than its spike and green or foliaceous. 


\section{Carex varia $\mathbf{l}$ ruhl.}

Stems $6^{\prime}-18^{\prime}$ high, rather stout, erect or spreading, roughish above the middle; basal bracts bright purple, fibrillose; leavies mostly shcrter than the culm, 1" -2 " wide, rough; staminate spike clavate, $4^{\prime \prime}-12^{\prime \prime}$ long, sessile or short-stalked, tawny or brown; pistillate spikes $2-5$, usually 3 , globular or oblong, sessile or sometimes the lowest short-peduncled, all separate or the upper 2 occasionally contiguous, each with a scale-like bract or the lower 2 subtended by leaf-like bracts $\frac{l^{\prime}}{2}-2^{\prime}$ long; perigynia subrotund or obovate, pubescent, abruptly contracted into a short bifid beak, covered by the ovate, pointed, pale-greenish, whitish or tawny-brown scale. (C. communis Bailey, Gray's Man., 6th ed.)

It is noteworthy that the smallest plants often haro the long staminate spikes, and commonly the tall plants the short spilies which are $4^{\prime \prime}-6$ " long. In his description of this species Muhlenberg remarks, "variat spica mascula abbreviata et elongata." No other species in this group is known to have such a variable staminate spike.

In some of its forms C. Pennsylranica approaches this species, but the absence of creeping rootstocks, the paler scules of the pistillate spikes and the more constant green foliaceous bract of the lowest spike will distinguish this plant. The scale of the pistillate spilie is often entirely whitish or scarious except the green midrib. The species is found chiefly in hilly or rocky places in loose or grarelly soil. It seems to aroid sandy soil. It matures its fruit in May and June.

Tho namo C. varia MUul, formerly applied to this species was referred by Prof. Bailey to C. Emmonsii Dew., and in its place he substituted C. conmunis Bailey. This name was discarded in the List of Plants of Northeastern North America, and C. pedi. cellata Britton adopted in its stead.

\section{Carex Emmonsii Dero.}

Stems capillary, $3^{\prime}-15^{\prime}$ high, suberect or procumbent, smooth; basal sheaths dull purplish-brown, mostly green at the extremities, slightly fibrillose; leares lax, about $\frac{1}{2}$ " wide or more, flat, rough-margined, shorter than the culm or sometimes surpassing it; staminate spike slender, subclavate, sessile about 3 "long, 
acute or obtuse, commonly pale, but dark brown in the rariety; pistillate spilies $2-1$, oroid, sessile, the upper 2 contiguous, the other distinct, densely 3-9 1lowered, each with a scale-liko bract, the lowest often bristle-tipped, or rarely leaf like; perigynia triangular-oval, pubescent, with a long slender base, contracted abore into a narrow, oblique, bifid beak, usually about the length of tho body; scale orate-oblong, poiuted, whitish, barely tinged with brown, as long as the perigynium.

Commonly in dry places but sometimes in low wet soil. Common. Nay, June.

Tho species is easily recognized by its weak reclining or prostrate stems, contiguous or approximate pistillate spikes and short, narrow, sessile, staminate spilie.

Var. distincta IIowe $n$. var. Light or glaucous green; staminate spike linear $\mathbb{I}^{\prime \prime}$ wide, $2^{\prime \prime}-5$ " long; pistillate spiles distinct, $2 "--5$ " apart, the lowest with a green bract $2-1$ times the length of the spike, 3-5 flowered; perigynia obovoid, minutely pubescent, with a rather short, straight or oblique bifid beak, about the length of the acute white scale.

This variety seems to be intermediate between the type and $\mathrm{C}$. Novæ-Anglix.

Var. colorata. Differs from the type only in its dark purple scales, which gire a much darker color to the spilies than in the type. Common in Westchester county. It is C. varia $M$ Luhl. var. colorata Bailey in the Manual.

\section{Carex Novæ-Angliæ Schro.}

Stoloniferous; stems $4^{\prime}-12^{\prime}$ high, slender, diffuse or erect, slightly rough above the middle, usually purple and a little fibrillose at the base; leares mostly shorter than the culm, $\frac{1}{2}^{\prime \prime}-1^{\prime \prime}$ wide, flat, erect or spreading, rough-margined, bright green; staminate spilie linear, $3^{\prime \prime}-6^{\prime \prime}$ long, $\frac{1}{2}$ "wide, short-peduncled or subsessile, light brown; pistillato spilies 1-3, ovoid, densely flowered, the upper 2 contiguous, or sometimes $3^{\prime \prime}-6$ " apart, sessile or the lower one on a short pedicel, each with a scale-like awned bract longer than the spike, the lowest distant, conspicuously stalked, subtended by a green filiform bract nearly or fully equaling tho culm; perigynia triangular obovoid, slightly pubescent, tapering to a short base and abruptly contracted 
above into a short, slender, bidentate beak, mostly covered by the ovate acute or pointed whitish scale.

Damp soil in shaded hilly places. Rare. Rensselaer county. June.

The distant lorrest pistillate spike with its long slender green bract and the very narrow short-peduncled staminate spike are noticeable features of this species.

\section{Carex Peckii IIorce.}

Strongly stoloniferous; stems $3^{\prime}-18^{\prime}$ high, slender, erect or spreading, smooth, purplish and lightly fibrillose at base; leares mostly much shorter than the culm, $1^{\prime \prime}-1 \frac{1}{2}$ "wide, open and flat, soft, erect or spreading, rough-margined, bright green; staminate spike linear, 1 1" ${ }^{\prime \prime} 3^{\prime \prime} \mathrm{long}$, sessile, often invisible, scales brown, white-margined; pistillate spikes 2-3, ovoid, sessile, 2-9 closely flowered, the upper two crowded, usually concealing the staminate spike, each with a green setaceous or short-awned, dirergent bract mostly not longer than the spike, the lowest $11_{2}^{1 \prime}-2^{\prime \prime}$ distant, subtended by a green divergent bract about twice the length of

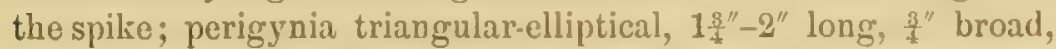
hairy, with an evenly tapering base and a short bidentate beak, longer than the ovate acute or cuspidate whitish or brownish scale; achenium exactly elliptical, $\frac{1}{2}$ " wide, substipitate, the style deciduous at its base.

Dry soil in woods and open places. May, June. Albany, Essex, Jefferson, Cayuga and Yates counties.

This is C. Emmonsii Dew. var. elliptica Boott.

\section{Carex deflexa ITornem.}

Densely tufted; stems $2^{\prime} \cdot 6^{\prime}$ high, capillary, curved, diffuse, smooth; basal bracts acute or cuspidate tibrillose, dull brown or purple; leaves shorter or longer than the culm, $\frac{1}{2}{ }^{\prime \prime} \mathbf{1}^{\prime \prime}$ wide, smooth, open and flat; staminate spike small and inconspicuous; pistillate spikes 1--3, usually 2, contiguous, 2-6 flowered, $1^{\prime \prime}-1 \frac{1}{2}^{\prime \prime}$ in length and thickness, green or brownish, the lowest slightly peduncled with a green filiform bract $2^{\prime \prime}-4^{\prime \prime}$ long ; radical spikes occasional; perigynia pyriform, tri-costate, thinly pubescent, contracted above into a short, flat, slightly curred or oblique beak, a little exceeding the orate acute or acutish, green and purple glume. 
Adirondack mountains. July.

It forms small dense tufts, the short capillary stems often being prostrate at maturity, the longer leares partly concealing the fruit; or, they are suberect, and the spikes drooping; by which, and the apparent absence of the sterile spilies, this delicate species may be readily known.

Var. Deanei Bailey. Stems $6^{\prime}-12^{\prime}$ high, mostly longer than the leaves; staminate spike $2^{\prime \prime}--3^{\prime \prime}$ long, less than $\frac{1}{2}$ " wide, often oblique; pistillate spikes $4-8$ flowered, $2^{\prime \prime}-3^{\prime \prime}$ apart, the lowest conspicuously stalked, its bract leaf-like and longer than the culm; radical spikes few or numerous.

Adirondack mountains.

\section{Carex Richardsonii $R$. $B r$.}

Stoloniferous; stems $4^{\prime}-9^{\prime}$ high, stiff, erect or recurved-spreading, rough; basal bracts dull purple or tawny; leaves shorter than or as long as the culm, $1^{\prime \prime}-1 \frac{1}{2}^{\prime \prime}$ wide, smooth, rough margined, their extremities often involute, stiff, erect or recurved-spreading; staminate spike clavate, about $\mathbf{1}^{\prime}$ long, on a short stalk or subsessile, conspicuously mottled; pistillate spikes $1--2,3^{\prime \prime}-9^{\prime \prime}$ long, densely flowered, approximate, erect, the lowest on an included stalk, its sheath (or bract) 6"-9" long, acute or acuminate, usually corering the lowest scale, dark purple or brown; perigynia subglobose or obovoid, thickly pubescent, obscurely nerred, with a long tapering bise, contracted abore into a short point with an entire or erose orifice; scale ovate-oblung, obtuse, purplish-brown with scarious margins.

Dry ground. liare. Monroo county.

This species seems to be quite local. It is, however, well marked by its purplish bracts and by its spikes appearing as if spotted with purple or brownish-purple.

\section{Carex pubescens MUhl.}

Stems $1^{\circ}-2^{\circ}$ high, erect, hairy; leares shorter than the culm 11"-21." wide, pubescent, dull green; staminate spilio subclavate, on a peduncle $3 "-6$ " long, orect, tawny; pistillate spilies $2-4$, oblong or short cylindrical, subdensely flowered, $5^{\prime \prime}-9^{\prime \prime}$ long, approximate, the upper 2 sessilo or nearly so, the lowest on stalls 3 " $-6 "$ in length, all orect; bracts conspicuous, the upper setaceous, the lowest leaf-like, 1'-2' long; perigynia acutely triangular- 
obovate, densely hairy, 2 "long, $x^{\prime \prime}$ wide, obscurely nerred, with a prominent bifid beak, a little longer than the oblong-ovate, cuspidate white scale.

Wet, grassy places. Common. June.

It is distinguished from the other species of this group by its larger size and gencral pubescence.

Staminate spike single, stalked, often fertile at the apex; pistillate spikes 3-5, cylindrical, densely or loosely flowered on a straight or flexuous rachis, all on filiform more or less drooping peduncles; bracts sheathing, longer or shorter than the culm; perigynia obtusely or sharply triangular ovate or fusiform with a long tapering bealk, slightly inflated.

Pistillate spikes densely flowered............... 1

Pistillate spikes loosely flowered ................ 2

1 Spikes clavate or cylindrical, green, perigynia sharply

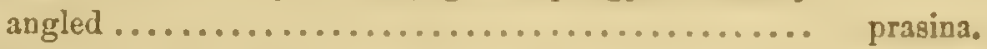

1 Spikes cylindrical, fulvous, perigynia obtusely angled... castanea.

2 Perigynia short-stalked ................ arctata.

2 Periggnia sessile ...................... 3

3 Perigynia tapering into a long beak ............. debilis.

3 Perigynia contracted into a rather short beak........ glabra.

\section{Carex prasina Wahl.}

Stems $15^{\prime}-30^{\prime}$ high, slender, often diffuse, slightly scabrous on the acute angles; leaves shorter than the culm, rough at ihe sum. mit and on the margins, $1 \frac{1}{2}$ " wide or less ; staminate spike cylindrical or club-shaped, $1^{\prime}-1 \frac{1}{4}^{\prime} \operatorname{long}$, on a filiform peduncle $\frac{1^{\prime}}{4}-1^{\prime}$ in length, mostly drooping, often with a fow pistillate flowers at the apex; pistillate spikes $3-t_{\text {, cylindrical, }} \frac{1}{2}^{\prime}-1 \frac{1}{2}^{\prime} \mathrm{long}$, densely flowered or loosely flowered at the base, on filiform nodding stalks, the upper 2 or 3 approximate, the lowest remote on a peduncle $1 \frac{1}{2}^{\prime}-2 \frac{1}{2}^{\prime}$ in length; bracts leafy, the lower ones usually surpassing the culm, the upper 1 or 2 often slender, scarcely exceeding the spike; perigynia acutely triangular, few-nerved, tapering each way from below the middle, terminating above in a short, smooth, minutely-notched or entire beak, exceeding the oblong-ovate, acute or cuspidate white scale; achenium triangular-elliptical, apiculate.

Moist or wet fields and woods. Common. May, June. 
The pistillate spikes, when fresh, are ra'e green and more densely flowered than in any of the other members of this group.

This is C. miliacea $M[u h$. of the older botanies.

\section{Carex arctata Boott.}

Stems $1^{\circ}-2^{\circ}$ high, slender, erect-spreading or diffuse, smooth, somerwhat stoloniferous, basal bracts dark purple; leares mostly shorter than the culm, rarlical leaves numerous, $1 \frac{1}{2}-5^{\prime \prime}$ wide, smooth, rough-margined; staminate spike linear, $6^{\prime \prime}-9^{\prime \prime}$ long, its filiform stalk $5^{\prime \prime}-8^{\prime \prime}$ in length, often inconspicuous; pistillate spikes $3-5, \frac{y^{\prime}}{2}-1 \frac{y^{\prime}}{4}$ long, loosely flowered on a llexuous rachis, all on drooping peduncles $\frac{1^{\prime}}{2}-3^{\prime}$ long, scattered, or the upper 2 approximate, the highest usually extending abore the staminate spike, the lowest remote; bracts leafy, sheathing, or tho upper mostly filiform, equaling or extending above the culm; perigynia orate, stipitate, nerved, obtusely angled, tapering to a short bidentate beak, longer than the white, acute or cuspidate scale; achenium obovoid, apiculate.

Woods and sluaded banks. Common. May, June.

The stipitate perigynia constitute a distinguishing feature of this species.

C. arctata $\times$ castanea Bailey. Pubescent; spikes $1^{\prime \prime}$ wide, loosely flowered, green or yellowish, somewhat approximate, erect-spreading or drooping; perigynia ovate, nerved, hairy, with a short bifid beak a little exceeding the acute whitish scale. (C. Knieskernii Dew.) In the List of the Plants of Northeastern North America this stands as C. arctata $\times$ formosa Bailey.

\section{Carex debilis $M[x$.}

Stems $1^{\circ}-2 \frac{1}{2}^{\circ}$ high, slender, erect or spreading, smooth, sometimes stoloniferous; leaves shorter or longer than the culm, $1 \frac{1}{2}-2^{\prime \prime}$ wide, spreading, rough; staminate spilio linear, pistillate at the summit, short-stalked or subsessilo; pistillate spikes $3-5$, linenr or narrowly cylindrical, loosely flowered on a flexuous rachis $1^{\prime}-3^{\prime}$ long, the 2 or 3 upper approximate on drooping stallis $\frac{1^{\prime}}{2}-2^{\prime}$ in length, or the highest nearly erect, the lowest remote, pendulous on a penducle $2^{\prime}-3^{\prime}$ long, rarely branched at the base; bracts leafy, sheathing, excecling or equaling the culm; perigynia fusiform, nerved, $3^{\prime \prime}$ long, tapering into a long slender 
hyaline bifid beak, trice the length of the obtuse or acutish white scale; achenium exactly elliptical, stipitate, apiculate.

Fields and woods. Very common. June, July.

The species is distinguished by its long flexuous fertile spikes and its spindle-shaped perigynia.

Var. strictior Bailey. Stems taller and mostly erect; leaves firmer, $2^{\prime \prime}$ wide, spikes stiff and erect or erect-spreading; perigynia deep green, a little longer than the scale.

Var. interjecta Bailey. Stems tall, erect; pistillate spikes nearly erect, often compound at base, alternately flowered; perigynia shorter than in the type. Differs from tho last in its narrower leaves and more loosely flowered spikes.

\section{Carex glabra Boott.}

Stems $1^{\circ}-2^{\circ}$ high, slender, erect or somerrhat spreading, smooth ; basal bracts dark purple; leares about the length of the culm or less, $1^{\prime \prime}-11^{\prime \prime}$ wide, rough, bright green; staminate spike linear, 1' long or more, short-peduncled, of ten fertile at the apex; pistillate spilies 3-t, cylindrical, flexuous, subloosely flowered, $\mathbf{1}^{\prime}-1 \frac{y^{\prime}}{2}$ long, the upper 2 approximate, the lowest remote, all on filiform drooping peduncles $1^{\prime}-6^{\prime}$ long, or the uppermost shortstalked and suberect; bracts leafy or the upper ones filiform, sheathing, usually exceeding the culm; perigynia narrowly oblong-elliptical or lanceolate, nerved, $2 \frac{1}{2}{ }^{\prime \prime}-3^{\prime \prime}$ or more in length, gradually tapering into an empty sharply bidentate beak, twice the length of the obtuse brown-margined scale.

Wet places. Rare. June, July. Oneida and Otsego counties. The few flowered slightly llexuous fertilo spilies and the large perigynia are characteristic of this species, which approaches $\mathrm{C}$ debilis in appearance.

\section{Carex castanea Wahl.}

Stoloniferous; stems $1^{\circ}-2^{\circ}$ high, erect, acutely angled, lightly pubescent, basal bracts dull brown, pubescent; stem leares $1^{\prime}-3^{\prime}$ in length, the radical half as long as the culm or more, $11^{\prime \prime}-2^{\prime \prime}$ broad, soft-hairy, conspicuously reined, glaucous or fulvous-green; staminate spike clavate, usually acutish at each end, $6^{\prime \prime}-9^{\prime \prime}$ long, on a stiff stalk $\frac{\lambda^{\prime}}{2}-1^{\prime}$ in length, bright brown; pistillate spikes $2-1$, oblong, or cylindrical, densely flowered, sometimes sterile at the apex or base, $\frac{1}{2}^{\prime}-1^{\prime}$ long, $2^{\prime \prime}$ wide, the upper 2 or 3 aggregated on 
drooping stalks ${ }_{1}^{\prime}-1^{\prime}$ in length, the lowest distant and pendulous; bracts rariable, the lowest leafy, $2^{\prime}-3^{\prime}$ long, sheathing, the upper setaceous; perigynia ovate-lanceolate, $21^{\prime \prime}$ long, turgid, 2-ribbed, obscurely nerred, spreading, tapering into a long smooth or roughish, mostly entire beak, about one-third longer than the acute, fringed, brown scale.

Very rare. May, June. Oneida and Herkimer counties.

Well marked by its glaucous leaves, and its short, yellowish or brown spikes, the upper subtended by setaceous bracts. This is C. flexilis Rudge in the older botanies.

Perigynia moderately intlated.

Staminate spikes $1-4$, the terminal stalked; pistillate spikes 2-5, sessile or short-stalked (the lower ones long-stalked in 99), approximate or distant, ovoid, oblong or cylindrical ; bracts leafy, longer or shorter than the culm; perigynia oroid or oblongconic, nerred, smooth or pubescent, somewhat coriaceous in texture, with a short bifid beak.

Perigynia scabro-pubescent.................. scabrata.

Perigynia smooth or granular, pistillate spikes distant, purple............................. polymorpha.

Perigynia pubesecnt .................... 1

Perigynia smooth or slightly rough, spikes not purple.. 2

1 Pistillate spikes cylindrical, leaves involute ........ filiformis.

1 Pistillate spikes cylindrical, leaves not involute...... 3

3 Leaves and bracts exceeding the culm........... lanuginosa.

3 Leaves and bracts shorter than the culm.......... 4

4 Spikes ovoid or oblong, approximate............. vestita.

4 Spikes oblong-cylindrical, distant............... Iloughtonii

2 Pistillate spikes $6^{\prime \prime}-12^{\prime \prime}$ long, $2^{\prime \prime}-4^{\prime \prime}$ wide, leaves involute. striata.

2 Pistillate spikes $2^{\prime}-3^{\prime}$ long, $4^{\prime \prime}-5^{\prime \prime}$ wide, leaves tlat.... riparia.

\section{Carex scabrata Schro.}

Stems $1^{\circ}-2^{\circ}$ high, rather stout, rough on the angles; leares numerous, the upper ones surpassing the culm, $2^{\prime \prime}-3$ " wide, rough, light-green; staminate spike clavate, $6^{\prime \prime}-9^{\prime \prime}$ long, its peduncle $2^{\prime \prime}-6^{\prime \prime}$ in length ; pistillate spikes $3-5$, cylindrical, densely flowered above, thinly at the base, approximate or scattered, the upper 2 sessile and erect, the others on erect or spreading stallis $\frac{y^{\prime}}{2}-2 y^{\prime}$ in length; bracts leafy, sheathless or sometimes the upper ones short-filiform, the lowest surpassing the culm; perigynia oroid, 
nerved, slightly turgid, scabro-pubescent, contracted into a short obliquely toothed beak, exceeding the orate acute or cuspidate brown scale; achenium oborate, acutely triangular.

Scattered or in patches along streams and in wet places. Common. June.

A rather coarse but bright-green species with the fertile spikes of a bristly or squarrose appearance when mature. It is somewhat stoloniferous.

\section{Carex flliformis $L$.}

Stems $1^{\circ}-3^{\circ}$ high, slender, erect, obtusely angled, mostly smooth; basal bracts $1^{\prime}-2 \frac{1}{2}^{\prime}$ in length, pointed, purplish-brown, more or less fibrillose; leaves $1^{\prime \prime}-1 \frac{1}{2}$ " wide, carinate, prominently grooved, smooth, rough-margined, becoming doubled or involute when dry, shorter than the culm, the radical ones numerous and longer; staminate spikes $1-3$, rarely 4 , clavate or cylindrical, $1^{\prime}-2^{\prime}$ in length, on a slender peduncle 1'-21' long, subtended by a scale-like, bristle-tipped, or short setaceous bract; pistillato spilies $1-4$, usually 2 , cylindrical, densely flowered, or sometimes loosely at the base, subdistant or remote, sessile, or the lowest shortstalked, often staminate at the apex, $\frac{1^{\prime}}{3}-1 \frac{1}{2}^{\prime}$ in length ; perigynia obtusely triangular, ovoid, nerved, of a thick coriaceous texture, densely pubescent or tomentose, slightly inflated, contracted into a short, sharply toothed beak, mostly corered by the ovate lanceolate, pointed or rough cuspidate brown scale, the latter usually widely spreading at maturity.

Swamps and wet meadows. Common. June, July.

This species may be recognized by the long sterile, and grayish fertile spikes, and by the usually erect, narrow, carinate leaves. It seems to prefer cold elevated swamps and bogs, though by no means limited to them.

\section{Carex lanuginosa $N x$.}

Stems $1^{\prime}-2^{\circ}$ high, stout, erect, acutely angled, roughish above the middle; root stocis somewhat creeping; leares open and flat, smooth, $1^{\prime \prime}-1 \frac{1}{3}$ " wide, shorter ban the culm; staminate spikes $1-3, \frac{1}{2}-1 \frac{1^{\prime}}{2}$ long on stiti peduncles ${ }^{\prime}{ }^{\prime}-1 \frac{1}{2}^{\prime}$ in length; pistillate spikes $2-4, \frac{1^{\prime}}{2}-1^{\prime}$ in lengtin, $21^{\prime \prime}-3^{\prime \prime}$ thick, densely flowered, cylindrical, the uppermost usually sessile, tho lower distant on short stallis, or the lowest remete on a slender peduncle $\boldsymbol{1}^{\prime}-1_{\frac{1}{2}}^{\prime} \operatorname{long}$, 
spreading or suberect, the others mostly ascending; bracts leafy, the lowest sheathing, longer or shorter than the culm; perigynia ovate, nerred, densely hairy, abruptly contracted into a short bidentate beak, about the length of the orate cuspidate brown spreading scale.

Wet meadows, marshes and swales. Not rare. June.

This differs from the preceding in its open flat leaves, shorter bracts and stalked fertile spikes. The carinate or involute leaves of the former cause them to appear to be much more narrow than those of this spevies, Which is considered by some to be a mere variety of $\mathrm{C}$. filiformis.

\section{Carex vestita Willd.}

Stoloniferous; stems $1^{\circ} .3^{\circ}$ high, rigid, acutely angled, rough at the summit; basal bracts fibrillose; leares $1^{\prime \prime}-11^{\prime \prime}$ broad, rough, shorter than the culm; staminate spikes 1-2, clavate, mostly sessile, $\frac{3^{\prime}}{4}-1 \frac{1}{4}$ long; pistillate spikes $2-4$, ovoid or short-oblong, $5^{\prime \prime}-9^{\prime \prime}$ in length, compactly flowered, approximate or distant, rarely remote, sessile, erect, frequently with a few staminate flowers at the apex; bracts leafy, as long as the spikes, or the lowest $11^{\prime}{ }^{\prime}$ long; perigynia ovate, nerved, densely hispid-pubescent, contracted into a short beak, the white orifice erose or slightly notched; scale ovate, cuspidate, brown with a white margin.

Wet or dry sandy places. Rather rare. Albany, Richmond and Suffolk counties.

It is credited by Dr. Torrey to the western counties of the State, but if there, it must be very scarce.

\section{Carex polymorpha Muht}

Stems $1^{\circ}-2^{\circ}$ high, stout, strict, acutely angled, smcoth; leaves 1'-6' long or more, $1^{\prime \prime}-3^{\prime \prime}$ broad, smooth; staminate spikes 1-4, the terminal short or long-peduncled, clarate, $\frac{1^{\prime}}{2}-1^{\prime}$ long, frequently with a fow pistillate flowers at the base; pistillate spikes 1-2, usually cylindrical, densely flowered, occasionally sterile at the apex, $\frac{1}{2}^{\prime}-11^{\prime}$ long, on exserted erect stalks $\frac{1^{\prime}}{2}-1^{\prime}$ in length; bracts leafy. sheathing, mostly as long as tho spike; perigynia oblong-orate, nerred, conspicuously turgid, minutely papillose or smooth, abruptly contracted into a slendor purplish beak with 
an oblique, entire or slightly notched orifice, longer than the ovate, obtuse, dark purple scale.

"Western counties." Dr. Torrey in the N. Y. State Flora. It does not appear to have been collected in the State recently.

104. Carex striata $M x$.

Stoloniferous; stems $15^{\prime}-30^{\prime}$ high, stiff and erect, acutely angled, rough near the summit; basal bracts purple, fibrillose; leaves shorter or longer than the culm, $1^{\prime \prime}-2^{\prime \prime}$ wide, the upper surface rough, involute when dry; staminate spikes $2-3$, the terminal one $1^{\prime}-2^{\prime}$ long, short stalked or subsessile, the lowest with a seta. ceous bract $\frac{1}{2}^{\prime}-1^{\prime}$ in length; pistillate spikes $1-2$, distant or remote, the highest sessile, the lowest short-peduncled, densely or subdensely flowered, $9^{\prime \prime}-1 \delta^{\prime \prime}$ long, erect; bracts leafy, shorter or longer than the culm, or the highest about equaling it; perigynia oblong-ovate or subglobose, prominently nerved, smooth or roughish with a scattered pubescence, somewhat divergent, abruptly contracted into a short bifid beak with whitish teeth, about twice the length of the orate, obtuse or acute, thin scale.

Wet places and boggy shores of ponds. Suffolk county. June.

Var. brevis Bailey. More slender, the leaves and bracts shorter and narrower ( $1^{\prime \prime}$ wide), the fertile spikes narrower, the highest sometimes sterile at the apex and the perigynia pubescent; otherwise like the type.

\section{Carex Houghtonii Torrey.}

Stoloniferous; stems $1^{\circ} \cdot 2^{\circ}$ high, stiff, erect, acutely angled, rough at the summit; leaves shorter than the culm, $1^{\prime \prime}-2^{\prime \prime}$ wide, rough-margined; staminato spikes $1-2$, clavate, the terminal one on a stiff peduncle $\frac{1^{\prime}}{2} \cdots 1^{\prime}$ long, the lowest of ten with a setaceous or bristleform bract as long as the spike or longer; pistillate spikes 1-3, cylindrical or short oblong, subdensely flowered, $\frac{1^{\prime}}{2}-1^{\prime}$ long, subdistant, the upper two sessile, the lowest on an exserted stalk $3^{\prime \prime}-9^{\prime \prime}$ in length, all erect ; bracts leafy, sheathless, or the lowest short-sheathed, equaling or exceeding the culm; perigynia broadly orate, prominently nerred, rough-pubescent, abruptly contracted into a short, slender, sharply toothed beak, a little exceeding the ovate pointed or rough-awned brown scale; achenium broadly obovate, minutely dotted. 
Sandy soil. Rare. Essex and Saratoga counties. June, July. Sometimes the mature perigynia become reddish-brown or almost chestnut color.

\section{Carex riparia Curtis.}

Stoloniferous; stems $2^{\circ}-31_{2}^{\circ}$ high, stout, acutely angled, rough abore the middle, Haccid at the base; leaves longer than the culm, $2^{\prime \prime}-5^{\prime \prime}$ wide, mostly smooth on the upper surface, rough beneath, erect or spreading, glaucous; staminate spikes 2-5, cylindrical, the highest $1 \frac{1}{2}^{\prime}$ in length on a stalk $1^{\prime}$ long or less, the lowest with a setaceous bract $1^{\prime}-1 \frac{1^{\prime}}{2}$ long; pistillate spikes 24 , densely flowered, or loosely at the base, cylindrical or clavate, $1 \frac{1^{\prime}}{2}-3^{\prime}$ long, $4^{\prime \prime}-5^{\prime \prime}$ thick, distant, the uppermost subsessile, the others short-peduncled, all erect, or the lowest sometimes spreading; bracts leafy, equaling or exceeding the culm; perigynia oblong.conical, finely nerved, smooth, gradually tapering into a short conical bidentate beak, a little longer than the orate-lanceolate, awned scale; achenium narrowly obovate, apiculate.

Bogs, swamps and wet places. Common. June.

This is readily determined by the large erect spikes and oblong-conical, finely-nerved, olive-brown perigynia. It is C. lacustris Willd.

Staminate spikes 1-5, stalked or the lower ones sessile, rarely fertile at the apex; pistillate spikes 1-1, cylindrical or shortoblong, densely or subdensely flowered, subapproximate, distant or remote, sessile or nearly so, erect; bracts leafy, the lower short-sheathing or sheathless, mostly surpassing the culm; perigynia turgid, ovate-lanceolate, nerved, pubescent or smooth, with a long bifurcate beak, the teeth mostly recurved-spreading.

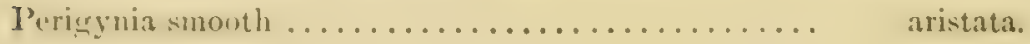

Perigynia hairy....................... 1

1 Staminate spikes $1-2 \ldots \ldots \ldots \ldots \ldots \ldots \ldots \ldots \ldots \ldots \ldots \ldots \ldots$ hirta.

1 Staminate ppikes $2-5 \ldots \ldots \ldots \ldots \ldots \ldots \ldots \ldots$ trichoearin.

\section{Carex hirta $L$}

Stoloniferous; stems 8 '-2 't' high, slender, orect or spreading, smooth below the summit, obtusely angled; leares shorter than the culm, or, in low forms, the radical surpassing it, $\mathbf{1}^{\prime \prime}-1 \mathrm{y}^{\prime \prime}$ wide, 
scabro-pubescent, densely hairy on the sheaths, light green; staminate spikes 1-2, cylindrical, $\frac{1^{\prime}}{2}-11^{\prime}$ long, on a slender peduncle $1^{\prime}-2^{\prime}$ in length, the lowest ${ }^{\frac{1}{2}}$ long and sessile; pistillate spikes 1-3, distant or remote, the highest sesile, the lowest on an included stalk $\frac{1}{2}^{\prime}-1^{\prime}$ in length, erect, subdensely flowered, $\frac{8^{\prime}}{4}-1 \frac{1^{\prime}}{2}$ long; bracts leafy, the lowest sheathing, surpassing the culm; perigynia ovate-oblong or lanceolate, prominently nerred, turgid, downy-pubescent, $3^{\prime \prime}$ long, tapering into a long slender bifurcate beak, longer than the ovate rough-awned scale.

Introduced. Rare or local. Cayuga county. June, July.

It is separated from the next by its light green foliage and downy sheaths, and by its fewer, softer fertile spikes.

\section{Carex trichocarpa Iluhl.}

Stems $2^{\circ}-3^{\circ}$ high, rigidly erect, acutely angled, smooth or hispid on the angles above; leaves stiff, rough, $2^{\prime \prime}-3^{\prime \prime}$ wide, longer than the culm; staminate spikes $2-5$, linear or subclavate, $\frac{1^{\prime}}{2}-1 \frac{1}{2}^{\prime}$ long, the terminal short-stalked, rarely with a few fertile flowers at the base or apex, the lowest, which is frequently the longest, with a bristleform bract, each tapering to an acute apex; pistillate spikes 2-t, distant, short-peduncled, or the highest subsessile, erect, cylindrical, closely flowered above, somewhat loosely at the base, $1^{\prime}-2 \frac{1}{2}^{\prime}$ long or more; bracts leafy, sheathless, longer than the culm; perigynia oblong-ovate, prominently nerved, hispidly pubescent, gradually tapering into a long bifurcate beak, the teeth sharp and spreading; scale orate-lanceolate, thin, brown with scarious margins, shorter than the perigynium; achenium obovate, apiculate, smooth.

Marshes and wet places. Common. June, July.

Prominently marked by its $2-5$ narrow acute sessile sterile spikes, and its rough-hairy, deeply cleft perigynia.

Var. imberbis Gray. A reduced form with rough sheaths, smooth perigynia and mostly longer scales.

\section{Carex aristata $R . B r$.}

Stems $1^{\circ}-21^{\circ}$ high, erect, stout, acutely angled, smooth below the spilies; leaves longer than the culm, $1 \frac{11}{2}-3^{\prime \prime}$ wide, smooth, rough on the margins, stiff, yellowish green; staminate spikes 1-4, club-shaped, the uppermost on a stalk $\frac{1}{2}-1^{\prime}$ long; pistillate 
spilies 2-4, distant, the upper tro sessile, the lowest on a short included stalk, densely flurered, $9^{\prime \prime}-24^{\prime \prime}$ in length; bracts leafy, the lowest sheathing, mostly longer than the culm; perigynia oblong-ovate, smooth, prominently nerred, $3^{\prime \prime}-3 \frac{1}{2}{ }^{\prime \prime}$ in length, gradually tapering into a long and slender bifurcate bea's, the awn-like teeth recurved, a little longer than the ovate-lanceolate, hispidly-awned scale; achenium elliptical, apiculate, very minutely papillose.

Very rare. June. Jefferson county.

Staminate spike solitary; pistillate spikes cylindrical, pendulous; perigynia stipitate, lanceolate, finely and densely nerved, with a slender deeply cleft beak, strongly reflexed at maturity.

Perigynia with long, very strongly recurved teeth.. comosa.

Perigynia with long straightish or divergent teeth. Pseudo-Cyperus.

\section{Carex comosa Boott.}

Stems $2^{\circ}-3^{\circ}$ high, robust, erect, acutely angled, flaccid at the base, rough above the middle, smooth below; leaves surpassing the culm, $4^{\prime \prime}-5^{\prime \prime}$ broad or more, rough toward the extremities; staminate spilie cylindrical, $1 \frac{1^{\prime}}{2}-1 \frac{3{ }^{\prime}}{4}$ in length, subsessile or shortstalked, with a filiform bract mostly exceeding the culm; pistillate spikes $3-5,1^{\prime}-2 \frac{1}{2}^{\prime}$ long, $5^{\prime \prime}-7^{\prime \prime}$ wide, compactly flowered, the upper two, or sometimes three, approximate, the lowest distant or remote, all on slender pendulous peduncles, frequently sterile at the apex; bracts leafy, sheathless, surpassing the culm; perigynia stipitate, lanceolate, densely nerved, gradually tapering into a long, slender bifurcate beak, the awn-like teeth strongly recurved; perigynia reflexed at maturity; scale lanceo. late, bristle-tipped, a littlo sborter than the perigynium.

Shores and wet places. Common. July, August.

The strongly recurved teeth of the reflexed perigynia, the former as conspicuous at the time of flowering as at maturity, are characteristic of this species, which is closely allied to the next following one, of which, by some, it is considered a variety.

\section{Carex Psoudo-Cyperus $L$.}

Stems $2^{\circ}-3^{\circ}$ high, stout, sharply angled, smooth below the spikes, slightly flaccid at the base; leaves rough, $2^{\prime \prime}-4^{\prime \prime}$ wide, much surpassing the culm; staminate spike cylindrical, $1 \mathfrak{y}^{\prime}-2 x^{\prime}$ in 
length, short-peduncled, with a filiform bract one-half the length of the spike or more; pistillate spikes 2-5, compactly flowered, exactly cylindrical, $2^{\prime}-3^{\prime}$ in length, usually one or more compound at the base and sometimes sterile at the apex, the upper ones mostly approximate and the lowest distant, all pendulous on filiform peduncles $\frac{I^{\prime}}{2}-2^{\prime}$ long; bracts leaf-like, sheathless, rough on both surfaces, much surpassing the culm; perigynia triangularlanceolate, prominently nerved, smooth, stalked, gradually tapering into a short forked beak, tho sharp teeth straight or spreading; scale lanceolate, rough-awned, about the length of the perigynia which are strongly reflexed at maturity.

Shores and wet places. Common. July, August.

Closely like the preceding when mature, but the spikes are more evenly cylindrical, and the teeth of the perigynia less spreading, and not so strongly recurred. Also, in its early stage it has been contounded with the next fullowing species, which it resembles, but 1ts longer spilies and peduncles should distinguish it.

Yerigynia much inflated.

Staminate spike single (rarely 2), stalked, sometimes fertile at the summit or base; pistillate spilies $1-t$, approximate, or the lowest distant and spreading, the upper subsessile and suberect or all on short stalks, spreading or drooping, densely flowered, squarrose.

Pistillate spikes erect, $3^{\prime \prime}$ wide, perigynia 8 -nerved ... Baileyi. Pistillate spikes 6 " wide, perigynia 10 -nerved ....... tentaculata. Pistillate spikes $5 "--6^{\prime \prime}$ wide, the lower drooping ..... hystricina.

\section{Carex hystricina $M u h l$.}

Stems $15^{\prime}-24^{\prime}$ high, erect, acutely angled, rough abore the middle or near the summit, smooth and flaccid at the base; leares mostly surpassing the culm, $1 \frac{1}{2}{ }^{\prime \prime}-3^{\prime \prime}$ wide, rough above the middle and on the margins; staminate spike singlo (rarely 2), cylindrical, $1^{\prime}-2^{\prime}$ long, mostly short-peduncled, light brown; pistillate spikes 2-3, oblong or cylindrical, densely flowered, $\frac{3^{\prime}}{4}-1 \frac{1}{2}^{\prime}$ long, the lowest often with 1 or 2 short branches at the base, approximate, the uppermost subsessile and spreading, the others on short nodding peduncles; bracts leaf-like, with obsolete sheaths, much surpassing the culm; or the highest often filiform and about equaling it; perigynia oroid or ovate-lanceolate, smooth, many- 
nerved, gradually tapering into a long, sharply toothed beal; scale, ovate-lanceolate, rough-awned, shorter than the widely divergent or horizontally spreading perigynia.

Wet places. Very common. June, July.

This species may be distinguished from the next by its longerstalked drooping spilies and by its smaller, many-nerred perigynia. In cold, springy, sterile soil a small form occurs with only one or two fertile spikes which are erect and nearly sessile. The scales of the sterile spikes of this species and C. PseudoCyperus are strikingly alike.

\section{Carex tentaculata, Muhl.}

Stems $18^{\prime}-30^{\prime}$ high, erect or spreading, acutely angled above the middle, rough at the summit, mostly smooth below; leares $11^{\prime \prime}-3^{\prime \prime}$ wide, rough, longer than the culm; staminate spike linear, very rarely with an additional short spike at its base, $1 \frac{1}{2}^{\prime}-2 \frac{1}{2}^{\prime}$ long, short-peduncled; pistillate spikes 2-4, compactly flowered, ovoid-cylindrical, $\mathbf{1}^{\prime}-1 \frac{1}{2}^{\prime}$ long, the upper two contiguous, sessile or nearly so, erect or divergent, the others approximate or the lowest sometimes remote on a short stalk, horizontally spreading; bracts leaf-lilie, far surpassing the culm; perigynia turgid-oroid, thin, about 10-nerved, widely divergent when mature, tapering into a long, slender, roughly-toothed beak, about twice the length of the linear-lanceolate, rough-awned scale; achenium ovoid, minutely papillose, with a long curred persistent style.

Wet places. Very common. June, July.

This species may be identified by the short-stalked, horizontallyspreading lowest spike, and by the spreading, slender beaks of the perigynia, which give to the spikes a coarse, comose appear. anco. The name C. Iurida, Wahl, is applied to this plant in the last edition of the Manual. Rarely the staminate spike is fertile at the apex.

Var. flaccida (Bailey). Smaller, with 2-1 loosely flowered, approximate, sessile spilies $1^{\prime}$ long or less; the fruit longer than in tho typo and less abruptly contracted into tho beak; the spikes of a dull or reddish-brown color

Var. parvula P'aine. A diminutive form 5'-10' high with one or two globose or ovoid sessilo densely flowered reddish-brown spikes. 
C. tentaculata $\times$ lupulina $($ Bailey.). Resembles C. lupulina, but is every way smaller; staminate spike stalked, pistillate spikes approximate, sessile, erect-spreading, dull yellowish or greenish; perigynia turgid-ovate, about 15-nerved, the long slender beaks widely divergent; scales with long rough awns shorter than the perigynia.

In a meadow bog in Poestenkill with the abore-named species and $\mathrm{C}$. hystricina, the latter being the most abundant.

\section{Carex Baileyi Britton.}

Stems $19^{\prime}-20^{\prime}$ high, slender, erect, acutely angled, smooth or rough near the spikes; leares $1^{\prime \prime}-11^{\prime \prime}$ wide, rough, longer than the culm; staminate spike linear, $\frac{1}{2}-1^{\prime}$ long, short-stalked or sessile; pistillate spikes 1-3, compactly flowered, ovoid or exactly cylindrical, $\frac{1^{\prime}}{2}-1 \frac{1}{4}$ in length, $2^{\prime \prime}-3^{\prime \prime}$ thick, rigidly erect, sessile, or the lowest subsessile; bracts leaf-like, sheathless, far surpassing the culm; perigynia turgid-globular, about eight-nerved, evenly divergent, very abruptly contracted with a long, slender bidentate beak, a little exceeding the long, rough-awned scale; achenium triangular-elliptical, tapering to each end, minutely papillose, with a strongly curved style. (C. tentaculata var. gracilis Boott. C. lurida var. gracilis Bailey.)

Swamps and wet places. Adirondack mountains. July.

This slender handsome species bears but a slight resemblance to the preceding, of which it was long ago made a rariety by Dr. Boott; nor have intermediate forms been found which might possibly connect it with that species. On the other hand, it has, since it was first discovered, maintained its perfect identity as a mountain-loving species. It does not appear to descend into the lower regions, where the other species is so common. Even dwarf forms of the allied species have their fertile spikes thicker than those of the most luxuriant forms of this, and the two maintain their distinctive characters when growing side by side and under similar conditions. The name C. montamans was given to this species in the manuscript of this Report, but owing to the delay in its publication it becomes necessary to substitute for it the earlier published name of Prof. Britton.

Pistillate spikes $9^{\prime \prime}-12^{\prime \prime}$ broad, erect on stiff peduncles or the upper sessile; bracts prominently sheathing; perigynia 6 " long and $2^{\prime \prime}$ broad, ascending. Spikes hop-like in appearance. 
Pistillate spikes $1^{\prime}-2^{\prime}$ long, achenia without prominent

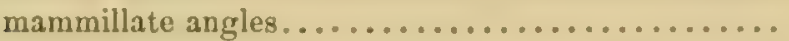

Pistillate spikes $2^{\prime}-3^{\prime}$ long, achenia distinctly mammil-

Iupulina. late on the angles..................... lupuliformis.

115. Carex lupulina Mht.

Stoloniferous; stems $2^{\circ}-3^{\circ}$ high, erect, rolsust, acutely angled, smooth; leaves $3^{\prime \prime}-6^{\prime \prime}$ broad or more, smooth, rough-margined, conspicuously nodose, reticulated on the upper surface, much surpassing the culm; staminate spike single (rarely two), cylindrical, $1^{\prime}-3^{\prime}$ in length on a peduncle $\frac{1^{\prime}}{2}-1 \frac{1}{2}$ long; pistillate spikes $2-6$, closely flowered, $I^{\prime}-2^{\prime}$ long, $8^{\prime \prime}-10^{\prime \prime}$ broad, the upper ones approximate, short-stalked or sessile, the others somewhat scattered and longer peduncled, or sometimes all sessile or nearly so, the lowest usually on a stalk $\frac{y^{\prime}-1 f^{\prime}}{2}$ long; bracts leaf like, prominently sheathing, mu sh surpassing the culm; perigynia ovate-lanceolate, conspicuously stipitate, prominently nerved, thin, $6^{\prime \prime}-9^{\prime \prime}$ long, erect-spreading, gradually tapering into a long bidentate beak, nearly twice the length of the lanceolate, awn-pointed scale; achenium triquetrous, sharply angled, stipitate, about $1 \frac{1}{2}$ long, scarcely 1 " broud, tapering each way from the middle, the apex continuous with the persistent tortuous base of the style.

Swamps and water holes. Common. July.

Var. podunculata Dew. Differs in its more scattered prominently peduncled spikes, its usually long-stalked sterilo spiko and the more divergent perigynia.

C. lupulina $\times$ retrorsa Dudley. Perigynia straw-colored, horizontally spreading; scale acute or short-awned.

\section{Carex lupuliformis Sartwell.}

Stoms $2^{\circ}-3^{\circ}$ high, stout, smooth, usually stoloniferous; leaves longer than the culm, $3^{\prime \prime}-6^{\prime \prime}$ wide, smooth, rough-margined; staminate spilio clarate, $11^{\prime}-3^{\prime}$ long, often long-stallied ; pistillate spilies 2-5, mostly 4 , cylindrical, closely flowered, the upper 3 contiguous, sessile, the others short-peduncled, the lowest distant or remote on an exserted stalk $y^{\prime}-1^{\prime}$ in length, all erect and stiff, $2^{\prime}-3^{\prime}$ long, $9^{\prime \prime}-12^{\prime \prime}$ broad or more; bracts fuliaceous, sheathing, far surpassing the culm; perigynia ovate-acuminate, $5^{\prime \prime}-9^{\prime \prime}$ long, much inflated, strongly nerred, thin, moro or less spreading, 
tapering from a stalked base into a long cylindrical, bidentate beak, about $t$ wice the length of the ovate-lanceolate, pointed or rough-awned scale; achenium nearly as broad as long, with a mammillate protuberance on each angle, and a long curved style. (C. lupulina var. polystachya Schw. and Torr.)

Marshes. Rare. Yates and Putnam cuunties. July.

The long spikes and peculiar achenia characterize this species.

Perigynia moderately or much inflated, ascending, divergent or deflexed.

Staminate spike single (rarely 2), clarate, stalked or sessile, rarely androgynous; pistillate spilies $1-5$, globose, oblong or short cylindrical, sometimes sterile at the apex, compactly subdensely or alternately flowered, sessile or peduncled, erect or spreading, the upper contiguous or approximate, the others dis. tinct or scattered or all scattered, green or jellowish-green at maturity; bracts leaf-like, with conspicuous or obsolete sheaths, erect or divaricate, longer than the culm; perigynia ovoid, lanceolate or awl-shaped, nerved, mostly smooth with a short notched or long bifurcate beak.

Spikes short-cylindrical, leaves involute.......... extensa.

Spikes globose or ovoid, distant, bracts sheathing.... I I

Spikes globose or oblong, contiguous above, bracts

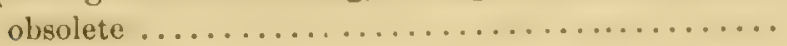

1 Spikes 4-8, distant, perigynia awl-8haped...........

1 Spikes subdensely or densely flowered, perigynia not

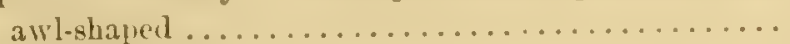

3 Leaves $2^{\prime \prime}-6^{\prime \prime}$ wide..................... folliculata.

3 Leaves about $1^{\prime \prime}$ wide ..................... Michauxiana.

2 Spikes 3-8-Hlowered, leaves involute ............. oligosperma.

2 Spikes more than 8 -flowered, leaves not involute.... 4

4 Perigynia deflexed when mature, its beak bent.... flava.

4 Perigynia with a straight beak...............

5 Perigynia small, with a short, minutely notched beak.. CEderi.

5 Perigynia much intlated, 6 " -8 " long ............. 6

6 Spikes 15-30 flowered, perigynia 25-30 nerved .... Grayii.

6 Spikes 3-12 flowered, perigynia 15-20 nerved..... intumescons.

\section{Carex Grayii Carey.}

Stems $12^{\prime}-30^{\prime}$ high, stout, acutely angled above, smooth; leares surpassing the culm, $2^{\prime \prime}-3$ " wide, rough, light greon; stam. 
inate spike linear or sub-clavate, $1^{\prime}$ long, often inconspicuous, sessile or short-peduncled ; pistillate spikes $1-3$, usually 2 , densely flowered, globular, contiguous or subdistant the uppermost sessile, the lower short-peduncled, erect, $6^{\prime \prime}-9^{\prime \prime}$ thick; bracts leafy, longer than the culm; perigynia turgid-ovate or oroid, 25-30 nerved, $6^{\prime \prime}-9^{\prime \prime}$ long, smooth, widely spreading and deflexed, tapering into a long bidentate, beak, about twice the length of the broadly orate, acute scale.

Wet places in the central and western part of the State, rare in the eastern part. July.

The large yellowish-green spikes, mostly contiguous and of a bur-like aspect, sufficiently mark this fine species. It is related to the next following species to which it has sometimes been subjoined as a rariety. It is C. Asa-Grayi Bailey.

Var. hispidula Gray. Perigynia hispidly-pubescent. Greene county.

\section{Carex intumescens Rudge.}

Stems $15^{\prime}-30^{\prime}$ high, slender, erect, acutely angled, smooth below the middle, sometimes with a few short stolons; leaves $1 \frac{1}{2} "-3$ " broad, rougb, longer than the culm, dark green; staminate spike cylindrical, $\frac{8}{4}^{\prime}-2^{\prime}$ in length, subsessile or on a stalk $\frac{1^{\prime}}{2}-1 \frac{1}{2}^{\prime}$ long; pistillate spikes 1-3,5-10 loosely or subdensely flowered (rarely 1-3 flowered), globular, contiguous or approximate, sessile or the lowest on a short stalk $3^{\prime \prime}-6^{\prime \prime}$ in length, dark green, often becoming blackish in drying; bracts leafy, sheathless, much surpassing the culm ; perigynia turgid-ovoid, 15-20 nerved, widely spreading, tapering into a long, smooth or roughish bidentate beak, about twice longer than tho oblong-orate cuspidate scale.

Wet places in fields or woods. Very common. June, July.

This species has more slender culms, darker foliage, fewer flowered spikes and fewer nerved perigynia than C. Grayii, to which it is closely related. It is quito rariable. In shaded places there is a very slender form with one to three perigynia in a spike; also in open places there is a very slender form with two to three scattered spikes having one to fivo rather small perigynia in each. These sometimes assumo a reddish-brown color even before maturity. 
119. Carex folliculata $L$.

Stems $15^{\prime}-30^{\prime}$ high, slender, erect, smooth; leaves $2^{\prime \prime}-6^{\prime \prime}$ wide, rough beneath, the lowest short and long-sheathing, the upper surpassing the culm; staminate spike small and often inconspicuous, $\frac{1}{2}^{\prime}$ long or more, sessile or short-peduncled ; pistillate spikes $3-4,10-20$ subloosely flowered, globose-oroid, $5^{\prime \prime}-8^{\prime \prime}$ broad, approximate, distant or remote, the uppermost sessile, the lower on exserted peduncles $\frac{1^{\prime}}{1^{\prime}} \mathbf{1}^{\prime}$ long, all erect, green or tawny; bracts leafy, sheathing, longer than the culm; perigynia oratelanceolate, many-nerved, inflated, smooth, widely spreading, gradually tapering into a short bidentate beak, longer than the ovate rough-awned, white scale.

Swamps and wet places. Common. June, July.

The species is easily recognized by its short, lower stem.leaves, and by its usually distant green or yellowish, subglobose spikes. On the sand plains west of Rome and in sphagnous marshes of the Adirondack region a short form occurs, having the pistillate spikes approximate, four of them being included in a spaco of $2 \frac{1^{\prime}}{2}-3^{\prime}$.

120. Carex Michauxiana Breckl.

Stems $10^{\prime}-20^{\prime}$ high, stifl, smooth; leares exceeding the culm, $1^{\prime \prime}-1 \frac{1}{2}$ "wide, rough or sometimes smooth below the middle, yellowish-green; staminate spikes $3^{\prime \prime}-6^{\prime \prime}$ long, sessile, mostly inconspicuous; pistillate spikes 1-3, densely florrered, globoseovoid, the upper contiguous and sessile, the lowest distant or remote on an exserted peduncle $\frac{y^{\prime}}{2}-1^{\prime}$ long, yellowish-green; bracts leafy, sheathing, longer than the culm; perigynia lanceolate, numerously nerved, inflated, smooth, erect, spreading or widely divergent, tapering into a short, slender bidentate beak, twice longer than the oblong, obtuse, light-brown scale. (C. rostrata MFx., O. Michauxii Schw.)

Swamps and bogs. Adirondack region. July.

More slender than the last; spikes fewer, more densely flowered, with the perigynia shorter and more slender, and the seale much smaller and awnless. An occasional form has the lowest spike on a peduncle fire or six inches long.

\section{Carex Collinsii Nutt.}

Stems $6^{\prime}-20^{\prime}$ high or more, slender, erect, rough above the middle: basal bracts purple; leaves exceeding the culm, $1^{\prime \prime}-1 \frac{1}{2}{ }^{\prime \prime}$ 
wide, rough, bright green; staminate spike linear, $3^{\prime \prime}$ long $\frac{1}{2}{ }^{n}$ wide, sessile; pistillate spikes 2-t, distant, sessile or the lowest on a short exserted peduncle, all erect, $4-8$ loosely flowered, green; bracts leafy sheathing, longer than the culm; perigynia awl-shaped, finely nerved, smooth, slightly inflated, $6^{\prime \prime}$ long, reflexed, with a long, slender, deeply cleft beak, the awn-like teeth deflexed at maturity; scale lanceolate, cuspidate, less than half the length of the perigynium. (C. subulata $M(x$.)

Swamps and wet places. Very rare. Long Island and Richmond county. June, July.

\section{Carex oligosperma $M \sqrt{x}$.}

Stems $15^{\prime}-30^{\prime}$ high, slender, erect or somewhat spreading, slightly rough on the acute angles above; leaves as long as the culm, 1" wide, becoming involute, smooth or rough-margined; staminate spilies 1 or 2 , clavate, $\frac{1}{2}^{\prime}-1 \frac{1}{2}^{\prime}$ long, on stalks $\frac{1}{1}^{\prime}-1^{\prime}$ in length; pistillate spikes 1--2, globular or oroid, 3--8 Howered, subdistant, the uppermost sessile, the lowest usually short-stallied, sometimes half staminate; bracts leaf-like, sheathless, shorter or longer than the cul $n$; perigy nia turgid ovate, $2^{\prime \prime}-22^{\prime \prime}$ long, $11^{1 / 2}$ wide, prominently nerred, ascending, contracted into a short sleuder bidentate Deak, longer than the ovate obtuse brown scale.

Bogs and marshes. Northern part of the State. July, August.

Conspicuously marked by its tall slender stems, involute leaves and few florvered, oroid spikes.

\section{Carex flava $L$.}

Stems $1^{\circ}-2^{\circ}$ high, erect, smooth; leaves shorter than the culm, $1^{\prime \prime}-1 \frac{1}{2}$ " wide, mostly smooth, yellowish-green; staminate spike subclarate, about $\frac{1}{2}$ long, sessile or short-stalked, erect or oblique, sometimes small and inconspicuous; pistillate spilies 1-4, ovoid or globular, compactly flowered, aggregated and sessile or the lowest subdistant and short-peduncled, yollowish-green or fulvous ; bracts leaf-like, sheathless, divaricate, longer than the culm; perigynia turgid-ovate, prominently nerved, smooth, tapering into a long, slender bent or recurved bidentate boak, strongly reflexed at maturity; scalo oblong-ovato acute or obtusish, brown, much shorter than the perigynium; achonium short, triangular, obovate, apiculate, blackish-brown. 
Bogs shores and wet places. Very common and variable. June to August.

A form sometimes occurs in which the staminate spike is fertile at the apex.

Var. graminis Bailey. Differs trom the type in its much smaller size, longer leaves which exceed the culm, its mostly erect bracts, and in its smaller, usually straight perigynia. The beaks are deeply cleft as in the type and occasionally slightly rough.

This variety is not rare in the Adirondack region.

Var. fertilis Peck $n$.var. Stems $15^{\prime}-20^{\prime}$ high, firm and erect, smooth; leaves $1 \frac{1}{2}{ }^{\prime \prime}-2^{\prime \prime}$ wide; staminate spike invisible; pistillate spikes 4-5, ovoid or short-oblong, 5"-6" long, 3" wide, compactly flowered, the upper 3 aggregated, sessile, the lowest subdistant on a partly included stalk $3^{\prime \prime}-5$ " in length; bracts short-sheathed, divaricate and recurved, $3^{\prime}-S^{\prime}$ long, or the upper sometimes setaceous; perigynia yellowish-green with long rough beaks, a little longer than the oblong, acute deep brown scale.

Low moist ground. Dutchess county. June.

The staminate spike is apparently almost or wholly fertile.

\section{Carex Ederi Ëhrh.}

Stems $5^{\prime}-20^{\prime}$ high, slender, smooth; leaves mostly exceeding the culm, 1" wide or more, smooth, yellowish-green, fading to fulvous when old; staminate spike $3^{\prime \prime}-9^{\prime \prime}$ long, often androgynous, sessile ; pistillate spilies $2-1$, oroid or short cylindrical, $3{ }^{\prime \prime}-S^{\prime \prime}$ long, densely flowered, aggregated, or the lowest subdistant, all sessile and erect, sometimes 1 or 2 proliterously branched at the base, yellowish.green; bracts leaf-like, erect, longer than the culm, or the upper sometimes seíaceous; perigynia obovoid, straight, prominently nerved, divercent or ascending, contracted into a short bifid or slightly notched smooth beak, longer than the ovate acute thin brown scale; achenium triangular, oborate, apiculate, sharply angled, blackish-brown.

Wet places. Common, especially in the western part of the State. July, August.

This is easily separated from C. flava, to which it is closely allied, by its much smaller spikes and smaller perigynia with a shorter, straight, smooth, slightly notched beak. In the last edition of the Manual it is referred to $\mathrm{C}$. flava as Var. viridula Bailey. 


\section{Carex extensa Good.}

Stems $1^{\circ}-2^{\circ}$ high, slender but strict, smooth; leaves shorter than the culm or sometimes surpassing it, involute, smooth; staminate spike clavate, $8^{\prime \prime}-10^{\prime \prime}$ long, subsessile; pistillate spikes densely flowered, ovoid or short cylindrical, $4^{\prime \prime}-9^{\prime \prime}$ long, $2 \frac{1}{2}-3$ " wide; the upper ones approximate, sessile, the lowest remote on a short partly included stalk; bracts like the leaves or the uppermost often setaceous, the lowest sheathing, surpassing the culm; perigynia ovate, prominently nerved, ascending or widely divergant, gradually tapering into a short bifid beak, longer than the orate acute or obtuse macronate deep-brown scale; acienium elliptical, substipitate.

Introduced and local. Coney Island and Long Island.

Distinguished from the last by its stiff involute leares, less approximate spikes and larger, firmer perigynia.

Spikes 1-4, the upper half or more of the terminal one fertile, sterile below, the others fertile, densely flowered; perigynia longbeaked, squarrose at maturity.

\section{Carex squarrosa $L$.}

Stems $1 \frac{1}{2}^{\circ}-3^{\circ}$ high, stiff and erect, acutely angled, smooth; leaves surpassing the culm, $11^{\prime \prime}-4^{\prime \prime}$ wide, lax and spreading, smooth, or rough above the middle; spilies $1-4$, ovoid or cylindrical, densely flowered, $6^{\prime \prime}-12^{\prime \prime}$ long, $4^{\prime \prime}-6^{\prime \prime}$ wide, usually approximate, short-peduncled, or the lowest on a stiff stalk $\frac{1^{\prime}}{2}-1^{\prime}$ long, all erect, the terminal one pistillate above, staminate below; bracts leafy, longer than the culm, or the uppermost sometimes not exceeding its spike; perigynia turgid, obovoid, lightly few nerved, thin and papery, abruptly contracted into a long slender bifid beak as long as the body, the teeth short and thin, horizontally spreading at maturity; scalo lanceolate, mostly concealed by the crowded perigynia; achenium elliptical.

Moist meadows and swales. Common. June, July.

This is a very distinct and pcculiar species not closely rolated to any other in our limits.

Forma robusta Peck. Stouter, leares firmer, mostly erect; spilies $8^{\prime \prime}-12^{\prime \prime}$ long, $6^{\prime \prime}-7^{\prime \prime}$ wide, $2^{\prime}$ apart, the lowest on a slender drooping pedundele $2^{\prime}$ long. 
Staminate spikes 1-1, short or long-stalked, often pistillate at the base or apex ; pistillate spiles 1-5, cylindrical, usually densely flowered, the upper approximate (clustered in 127), sessile or short-stalked, erect or spreading, the lower sometimes drooping, or all distant, short-stalked or sessile, erect or ascencling, sometimes sterile at the apex, straw-colored or tamny; bracts like the leaves, the lower sometimes sheathing, equaling or surpassing the culm; perigynia ovate or globular-ovoid, much inflated, nerred or nerveless, ascending or spreading (reflexed in 127) shining, with a prominent bidentate beak. (Spilies pendulous, loostly flowered and perigynia globular with a needle-shaped beak in 133.)

Perigynia large, $1 \frac{1}{2}^{\prime \prime}-3^{\prime \prime}$ wide................. 1

Perigynia small, less thin $1 \frac{1}{2}^{\prime \prime}$ wide...............

1 Pistillate spikes 2 or more, ascending............ Tuckermani.

1 Pistillate spikes 1 or 2, perigynia widely spreading... bullata.

2 Pistillate spikes less than $4^{\prime \prime}$ wide ............. 3

2 Pistillate spikes 4 " wide or more ............. 4

3 Spikes erect or spreading .................. monile.

3 Spikes drooping ..................... longirostris.

4 Spikes contiguous, perigynia reflexed......... retrorsa.

4 Spikes approximate or distant, perigynia not ruflexed, 5

5 Spikes distant ...................... utriculata.

5 Spikes approximate or the lowest enly distant...... Schweinitzii.

\section{2\%. Carex retrorsa Schno.}

Stems densely clustered, $2^{\circ}-3^{\circ}$ high, firm and erect, smooth with obtuse angles; leaves much longer than the culm, $1 \frac{1}{2}{ }^{\prime \prime}-4^{\prime \prime}$ wide, rough, bright green; staminate spikes $1-3$, often slightly pistillate above or at the base, cylindricsl, $1^{\prime}-2^{\prime}$ long; pistillate spikes $3-5$, densely flowered, cylindrical, $1^{\prime}-2^{\prime}$ long or more, $4^{\prime \prime}-5^{\prime \prime}$ thick, the upper contiguous and erect on short included stalks, the lowest sometimes distant or remote on a short or long partly drooping peduncle, one or more of ten compound at the base; bracts leaf-like, short-sheathing, or sometimes the uppermost filiform, all much surpassing the culm; perigynia ovoid, prominently fewnerved, thin, strongly reflexed, tapering into a long bidentate beak; scale short lanceolate, usually invisibl

Wet places and water holes. Common. June, July. 
Readily identified by the clustered spikes and reflexed perigynia.

Var. Hartii Gray. Slender; fertile spikes more or less distant, stalked, loosely flowered; perigynia slightly reflexed. (C. Hartii Dew.) This is regarded by Prof. Britton as a distinct species.

\section{Carex Tuckermani Dero.}

Stems $1 \frac{1}{2}^{\circ}-3^{\circ}$ high, stout, the acute angles rough ; leares rougb, $1 \frac{1}{2}{ }^{\prime \prime}-2^{\prime \prime}$ wide, exceeding the culm; staminate spikes $1-3$, cylindrical, $1^{\prime}-1 \frac{1}{2}$ long, on a stalk $\frac{1^{\prime}}{2}-1^{\prime}$ in length, the lowest sometimes with a few pistillate flowers at its base; pistillate spikes $2-4$, densely flowered, oblong or cylindrical, $z^{\prime}-2^{\prime}$ in length, $4^{\prime \prime}-6^{\prime \prime}$ thick, rather distant, the uppermost sessile, erect spreading, the remainder peduncled, the lowest sometimes remote and drooping; bracts leaf-like, sheathless, longer than the culm ; perigynia large, ovate, prominently nerved, thin, $4 \frac{1}{2}{ }^{\prime \prime}-5$ "long, $2 \frac{1}{2} "-3 "$ thick, contracted into a slender bidentate beak, twice the length of the lanceolate acute or pointed scale.

Wet places in shaded stations or open fields. Common. June, July.

The rather short thick spikes and the large orate shining perigynia are characteristic of this species. When very young the perigynia of this species and of C. intumescens, C. Grayii and some others with inflated perigynia aro rery pale or almost white.

\section{Carex bullata Schk.}

Stems $1^{\circ}-2^{\circ}$ high, slender, erect, acutely angled, rough abore, smooth below the middle, dark purple and tibrillose at the base; leaves smooth or roughish, stiff, mostly erect, $1^{\prime \prime}-11_{2}^{\prime \prime}$ wide, about the length of the culm; staminate spikes $2-3$, cylindrical or subclavate, $\frac{t^{\prime}}{2}-1 \frac{f^{\prime}}{2}$ in length on stallis $6^{\prime \prime}-9^{\prime \prime}$ long; pistillate spilies $1-2$, densely flowered, $6^{\prime \prime}-9^{\prime \prime}$ (rarely $1^{\prime}$ ) long, $3^{\prime \prime}-5^{\prime \prime}$ thick, sessile and erect, or, when 2, approximate or remote, the uppermost short-stalked or sessile, the lowest on a slender pedunclo $1^{\prime}$ long or less, erect or slightly spreading; bracts leafy with obsolete sheaths, usually exceeding the culm; perigynia ovate, much inflated, nerved, thick, shining, widely divergent, tapering into a long, smooth or minutely roughened, bidentate beak, longer than the lanceolate acute or obtuse scale. 
A very rare species but one well marked by its 1-2 short thick spikes, and its large shining widely divergent perigynia. No specimens of it are in the State Herbarium, but it is said to occur in Westchester county and in the valley of the Mohark.

\section{Carex monile Tuckm.}

Stems $2^{\circ}-3^{\circ}$ high, slender, erect, rough on the acute angles above the middle; leares longer than the culm, $1 \frac{1}{3}-2 \frac{1}{2} "$ wide, rough at the top and on the margins, lax and somewhat spreading; staminate spikes $2-4$, cylindrical or clarate, $1^{\prime}-1 \frac{1^{\prime}}{2}$ in length, usually on a stalk $1^{\prime}$ long; pistillate spikes 1-3, densely flowered, cylindrical, $1^{\prime}-2 \frac{1^{\prime}}{2}$ long, $3^{\prime \prime}-4^{\prime \prime}$ thick, scattered, the upper ones sessile and erect or erect-spreading, the lowest on a slender spreading stalk $\frac{1^{\prime}}{2}-1^{\prime}$ in length, or sometimes sessile and erect; bracts leaf-like, with obsoleto sheaths, far surpassing the culm; perigynia globose-ovate, much inflated, thin and papery, nerved, somewhat divergent, gradually tapering into a long bidentate beak, about twice tho length of the acute or pointed scale.

Wet places, margins of streams, etc. Common. July.

It may bo known by the slender stems and lax leares, and by the 2-3 distant or remote, mostly erect, narrow, densely flowered spikes, and the globose thin shining perigynia. Forms sometimes occur with a single pistillate spike, and such forms having the spike unusually thick might easily be mistaken for C. bullata. The species is very common in the Adirondack region.

\section{Carex utriculata Boott.}

Stems $2^{\circ}-4^{\circ}$ high, stout, acutely angled abore the leares, smooth, flaccid, conspicuously reticulated below the middle; leaves surpassing the culm, $3^{\prime \prime}-5^{\prime \prime}$ broad, nodulose-roughened, dark green; staminate spikes $3-\mathbf{4}$, the terminal one short-stalked, the others sessile, $\frac{1^{\prime}}{2}-3^{\prime}$ in length, the lowest with a slender bract exceeding its spike; pistillate spilies $2-5$, densely flowered, sometimes one or more staminate at the apex, cylindrical, $1 \frac{1}{2}^{\prime}-4^{\prime} \operatorname{long}, 4^{\prime \prime}-6^{\prime \prime}$ thick, scattered, the upper sessile, the lower short-stalked, all erect or nearly so; bracts leafy, the lowest short-sheathing, far surpassing the culm; perigynia small, turgid-ovate, of a thick texture, fow-nerved, divergent, abruptly contracted into a cylindrical, 
sharply-toothed beak, longer than the lanceolate acute or awned scale.

Srramps, bogs and margins of streams. Common. June, July.

The spikes are longer than in the last species, the perigynia are smaller and firmer. The species may be recognized by the nodose-netted stems and leares. It is common in the Adirondack region where there are small forms, Var. minor Boott, with spikes scarcely more than $\mathbf{1}^{\prime}-1_{\frac{1}{2}}^{\prime}$ long.

\section{Carex Schweinitzii Dew.}

Stoloniferous; stems $1^{\circ}-2^{\circ}$ high, erect, rough on the acute angles; leares longer than the culm, $11^{\prime \prime}-3^{\prime \prime}$ broad or more, rough, yellowish-green; staminate spikes $1-2$, clavate, $9^{\prime \prime}-12^{\prime \prime}$ long on peduncles $\frac{1^{\prime}}{2}-1^{\prime}$ in length; pistillate spikes $3-4$, densely flowered, often loosely at the base, and sometimes compound, occasionally staminate at the apex, cylindrical, $1^{\prime}-2^{\prime}$ long or more, $3^{\prime \prime}-t^{\prime \prime}$ thick, approximate, mostly on short spreading stalks, or sometimes the lowest remote on a filiform nodding peduncle 2 '-21' long bracts leaf-like, short-sheathing or not sheathing, longer than the culm; perigynia small, turgid-oroid, few-nerved, thin, divergent, gradually tapering into a slender bidentate beak, nearly twice the length of the rough-awned scale.

Swamps and borders of streams. Oneida and Herkimer counties. Apparently rare or wanting elsewhere. June.

\section{Carex longirostris Torr.}

Stems $20^{\prime}-30^{\prime}$ high, slender, erect, smooth; leaves shorter than the culm, $11^{\prime \prime}-2^{\prime \prime}$ wide, rough, light or glaucous green; staminate spikes 2-3, clavate, $1^{\prime}-1^{\prime}$ long, short-peduncled, yellowish-white; pistillate spikes $2-5$, loosely flowered, cylindrical, $1^{\prime}-Z^{\prime}$ long, distant, the uppermost short-stalked and mostly erect, sometimes half staminate above, the others on filiform, drooping pedunc'es $1 \frac{1^{\prime}}{2}-6^{\prime}$ in length; bracts leafy or the uppermost setaceous, the lowest barely sheathing, shorter than the culm; periyynia turgid-globular or globose-ovoid, 2-ribbed, nerreless, dirergent, smootb, very abruptly contracted into a slender bifid beak longer than the body; scale lanceolate, whitish, often with a long awnliko point, equal to or a little shorter than tho perigynia.

Dry rocky places in woods or clexrings. Not common. June.

A form with spikes less than one inch long is Var. minor Boott. 
(F.)

\section{EDIBLE AND POISONOUS FUNGI OF NEW YORK.}

The figures and descriptions of the "Edible and Poisonous Fungi of New York" here given have been prepared with a view to meet a growing and popular demand for information concerning a much-neglected department of economic botany, and to facilitate and encourage a more general acquisition of a knowledge of the natural food products of our State. Many who would gladly avail themselves of the agreeable and highly nutritious food afforded by our edible fungi are debarred from doing so by a lack of the knowledge necessary for a proper discrimination between the edible and the poisonous or worthless species. With this knowledge, the fear of the bad would no longer prevent the use of the good. With it many whose circumstances are such as to make it difficult or impossible to procure an adequate supply of animal food might often obtain a very good substitute for it by the slight labor of gathering it in the fields and woods.

European works on this subject are less satisfactory, because the species in this country are not wholly the same as in that. Some of them are not readily procurable because of their high price, others and cheaper ones are less desirable because of deficiency in the number or the character of their illustrations. It has been tho purpose of the writer in his attempt to elucidate this subject to be satisfactorily profuse in illustrations. The plates are of such dimensions as to admit of figures of natural size in all except a single species. Whenever it was necessary a whole plate has been devoted to a single species. In nearly all cases the appearance of the young as well as of the mature plant bas been shown, and in several instances well-marked varieties have also been illustrated. For the benefit of the botanical student the spores of each species have been figured, magnified to a uniform scale of four hundred diameters. A compound microscope and a micrometer are necessary to ascertain the shape and size of the spore.

Of each species a brief diagnosis or botanical description is first given for the use of botanists. This is followed by a more full description in plain and simple language which may readily 
bo comprehended by the general reader. This description has been made as concise as was compatible with completeness and with the avoidance of technical terms. It is supplemented by a statement of the usual dimensions of the plant, its habitat or usual place of growth, its time of appearance, its qualities as an esculent and its relations or resemblances to other species.

Sixty-three edible species baro been figured on thirty-nine plates, three poisonous ones on three plates and one unwholesome one on one plate. Of the sixty-tbree edible species, about forty have been tested as to their edible qualities by the writer. Of the remainder, all save four have been eaten without harm by some of his acquaintances or correspondents. The four unproved species have been recorded as edible by various writers and no word of suspicion has ever been raised against them, so that it may be asserted most confidently that no species here represented as edible is at all dangerous or deleterious if used with moderation and after proper selection and preparation. All the species are not equally sapid, tender or desirable, but any of them may be eaten with perfect safety, if collected in good condition and eaten in reasonable quantity. Nine of these species were first published as edible in the State ALuseum reports, seven having been proved by the writer, two by his friends.

Other species belonging to our flora have been classed as edible by various writers, but they are not included in the present work, because opportunity has not yet been found for a personal trial of their edible qualities or for making accurate figures of them. It is to be hoped that in due time it may be possible to include them in a supplementary publication which shall complete this work.

That there are dangerous species whose use as food should be most carefully avoided is an acknowledged fact, but the number of such species is far less than many suppose. According to the authority of those who havo especially investigated this subject. the dangerously poisonous species found in this country all belong to a single genus, Amanita. About a dozen species of this grenus have been found in our State, and of these, two are known to be harmless and edible, three or four only are commonly classed as poisonous, and probably a single ono of these is responsible for a vast majority of tho fatal accidents 
resulting from "mushroom poisoning." There are, however, some species in other genera that are capable of causing nausea, vomiting and derangement of the digestive organs. They are unwholesome because of their persistently bitter, acrid or otherwise disagreeable flaror, or because of toughness of texture or the possession of some quality repugnant to the stomach. They may indeed cause sickness and romiting, but the irritation they induce is soon apparent and quickly causes the rejection from the system of the offending substance and then the normal condition of the system is soon restored. Sometimes recorery in such cases may bo hastened by the administration of some simple emetic which will assist the stomach in its efforts to expel the unwholesome material.

The dangerous species do not appear to possess such irritating qualities. The symptoms of sickness do not appear till several hours after eating, genorally eight to filteen. Then the face exhibits an ashy paleness, there is distress in the region of the stomach, resulting in nausea, romiting and relaxation of the bowels, the extremities becomo cold, the pulse feeble, the sight affected, and finally stupor and death follow if relief is not obtained. To this lind of poisoning, atropine, the active principle of Atropa belladonna, has been found to be an antidote. It has been administered in doses of $\frac{1}{8}-$ to $\frac{1}{y} \sigma$ of a grain according to the severity of the case, and tho dose may be repeated if necessary. It should be administered in subcutaneous injections.

For two thousand years or more people have made use of mushrooms for food and from time to time death has resulted from their use, either through ignorance or carelessness. Still men persist in their use, and those who would uso them if they dared frequently ask how they may distinguish mushrooms from toadstools, the word "toadstools" indicating to them poisonous or harmful species. Many attempts have been made to answer this question and many rules have been formulated by the observance of which, it has been claimed, all difficulty and danger would be avoided. Some of these rules are entirely unreliable and to others there are so many exceptions that they are misleading and practically worthless. The rules vary according to the standpoint of the one proposing them. One who considers the Com- 
mon mushroon the only edible species seeks to separate it from all others, and says " avoid all which have white gills and a hollow stem." This rule precludes the use of many mushrooms which are just as good as the one it sustains, and at the same time it is not definite enough to limit the selection to the one intended. Another, thinking of the Delicious lactarius which has an orange-colored juice, says " reject all such as have a white milky juice." This rule forbids the use of səreral species of lactarius that are no more harmful and scarcely less sapid than the Delicious lactarius. Again we are told by some one who has in mind the poisonous amanitas, to "discard all mushrooms that have a warty cap or a membranous sheath at the bottom of the stem." This would be a very good rule if we might add to it the sentence, unless you know the species to be edible and safe. The Orange mushrom, which is deemed an edible species of first quality, has a membranous sheath at the base of the stem, and the Reddish amanita has a warty cap and yet is not only harmless but very good, so that the rule which would forbid the use of these species excludes more than is necessary. The same may be said of those directions which require the rejection of all mushrooms having a viscid cap or an acrid taste or whose flesh on being broken quickly changes to a blue color. And as to the old-fashioned silver spoon test, by which it was thought that a silver spoon thrust among cooking mushrooms would bo quickly tarnished if thoy were poisonous and remain bright if they were edible, that was long ago proved to bo most unreliable by a fatal experiment in which several persons lost their lives because the cook put confidence it. We are, therefore, forced to conclude that no abstract rulo is at present known by which the good can in every case be separated from the bad. The only safo and reasonable way to do this is to learn to recognize each species by its own pcculiar specific characters. It is in this way that we recognize the useful and esculent species among flowering plants, and it must bo in this way that we select our edible mushrooms. A little more care may be necessary in one case than in the other, because of a closer resemblance in some cases between grood and bad mushrooms than between good and bad floworing plants. The principle that is to govern in this 
matter is the same in both cases. The greater the number of edible species clearly recognizable by any one the greater the field from which he may draw his supplies. If he is acquainted with but one species he should limit his use of mushroums to that one species, unless he can avail himself of the more extensive knowledge of some one else or unless he is willing to take the risk of eating some poisonous or unwholesome species. In a few instances it is possible to affirm of certain groups of species or of certain genera, that no deleterious species are known in them. Thus we have in this State six species of morels and no morel is known to be poisonous. It is, therefore, possible for any one who is able to separate a morel from all other fungi, to eat morels with considerable confidence though he may not be able to distinguish one species of morel from another. The same may be said of puff balls. No harmful species is known among them, and he who can discriminate between puff balls and all other fungi does not incur very much risk in eating any pufi ball of good flavor, though he may not be able to distinguish the species from each other. The probability is that he will sulfer no karm by so doing, but there is not absolute safety. It is possible that somo rare species exists having deleterious qualities which have not yet been ascertained by experiment, hence the lack of absolute certainty; for we know by experience among the amanitas that excellent edible species may exist in the same genis with and be closely related botanically to dangerously poisonous species. Therefore, those rules which say all morels, all puff balls, and all fairy clubs may safely be eaten are too sweeping, and would be better if modified by the words, "so far as known."

Many mushrooms have a farinaceous taste or odor, or both taste and edor are of this character. Some have thought that all species having this meal-like llavor are edible, and indeed many of them are, and no dangerously poisonous species is known to have it. But occasionally a species has this flavor combined with or followed by a bitter or otherwise disagreeable flavor which would at least render the mushroom undesirable if not unwholesome. So that rules designed to aid in the selection of edible species have their exceptions and their weak points as well as the rules designed to protect us against the poisonous species. There 
is, therefore, no escape from the necessity of acquiring a knowledge of each species we would utilize, sulficiently clear and exact to enable us to distinguish it from all others. Whatever value investigators and experimenters, who are willing to tako some rislis for the good of others, may find in such rules or general principles, it is evident that they are not sufticiently definite, exact and reliable for general use. To any one willing to arail himself of the experience of others and to apply himself sutticiently to learn to recognize the species they have found to be edible, nature opens a field productive of much palatable and nutritious food, which is too often left to decay where it grew.

But some care is necessary in the selection of specimens of species known to be edible. The plants selected should be in good condition. Well grown, sound, fresh specimens only should be chosen. Old, partly-decayed, water-soaked, worm-eaten or withered plants should be discarded. Even young and sound ones should not be kept too long before they aro cooked. They are in some cases very perishable and deteriorate rapidly. If more have been collected at one time than are needed for a single meal it will generally be better to cook them all at once and keep them in a refrigerator in the cooked rather than in the raw state. As a rule it is better to cook them the same day they are col. lected. In tho-case of the inky fungi this will be absolutely necessary, for they will not keep in good condition from one day till the next. Some of the species literally grow up in a night and perish in a day. These also should be cooked with great promptness, for they are only desirable while young and before the gills have begun to chango to a black inky liquid. Puff balls should only be used while the inner llesh is pure and white. When the yellowish stains of maturity begin to appear they are no longer fit for food. No one would think of eating them after the flesh bas changed to the cottony dusty mass of maturity.

Many insects are fond of mushrooms. Both they and their larve feed on them and the latter often live in them. A mushroom may appear fair externally, but if it is cut or broken its flesh may bo seen to be full of holes or galleries excarated by larva, and perhaps a colony of the larva themselves may be found within. It is noedless to say that such specimens are 
unfit for food. Strange as it may seem, a colony of larva in the lower part of the stem of a mushroom will some. times affect disastrously the flavor of the cap or upper part which they have not yet invaded. This fact may explain in part the varying opinions of different writers concerning the flavor and edible qualities of certain mushrooms. Slight differences in flavor may also be attributed to differences in the character of the soil in which they grow, the amount of moisture in the atmosphere, degree of temperature, age and rapidity of growth and to exposure to the sun and wind. Old and slowlydeveloped individuals are likely to be less tender than young and rapidly growing ones. Differences in individual tastes will also account in part for differences of opinion on this point. There are also peculiarities of constitution which hare given origin to the saying, "What is one man's meat is another man's poison." One person can eat no egg, nor anything into which egg enters as an ingredient, without suffering or sickness. Another is made sick by eating strawberries, nevertheless egg and strawberries are not classed as poisonous. Still it is possible that some fungi as harmless as egg and strawberries may have been charged with poisonous qualities from some such accidental circumstance or individual peculiarity.

In collecting mushrooms for the table it is well, in all cases in which the stems are too tough for food, to cut the caps from the stems. In this way much dirt and useless material will be left where it belongs, and it will be possible in many cases to ascertain if the caps have been attacked by insects. Most often the larve mino their way up from the ground through the central part of the stem to the cap, and by cutting the cap from the stem their holes or galleries are exposed to view. In but few species are the stems sufficiently tender to be used. Some have recommended that the caps be placed in the collecting basket in an inverted position, for if placed in their natural position with gills downward they will drop their spores and their flavor will be impaired. It is very doubtful if this partial loss of spores affects the flavor in any appreciable degree. If more than one species should be taken during the same excursion it would be well to keep them separate from each other by wrapping each 
species in a piece of paper by itself. This precaution is not necessary if tho species are so distinct in color, shape or size that they can readily be separated from each other at home, or if they are so similar in flaror and texture that they may be treated alike in cooking without any detriment to their esculent qualities.

Should a doubt arise at any time, concerning the identity of a supposed edible species, do not use such a mushroom until all doubt on this point has been banished. If it is thought desirable to compare the plant with the published figures and descriptions for the purpose of identifying the species, select for this purpose sound specimens which represent both the young and the mature forms, that all the specific characters may be shown. Take the specimens up carefully from their place of growth, removing all the loose dirt from the base of the stem. Wrap the specimens carefully in soft paper or large green leares that they may be kept as fresh as possible till the time of examination. On reaching home, lose no time in making the examination for in some species there are evanescent characters which will not be available after a few hours' delay. In one family of fungi the color of the spores is an important character and a great aid in tho identification of species. The color of the spores in many species is the same as or similar to the color of the mature gills, but there are so many exceptions that explicit directions for ascertaining their color will be given in another place.

In the preparation of mushrooms for cooking, the utmost cleanliness should be observed. Some have the upper surface of the cap covered with a sticky, viscid or glutinous substance when fresh This often causes bits of dirt, leaves or sticks to adhere to the cap tenaciously. In such cases it is generally best to remore this rubbish by peeling the caps. In other cases the dirt may be wiped away with a damp cloth or towel, or washed off and then the surface dried with a towel. It is also well to peel those having a thick tough skin. In boleti, the stratum of pores on the lower surface of the cap is apt to form a mucilaginous or slimy disagreeablo mass in cooking. It is, therefore, well to remove it before cooking. It is easily separable from the cap and can readily be removed by pressing it outwardly from the stem with a knife blade. In very large thick-fleshed specimens it is best to cut in slices or chop in small pieces. 
The proper method of cooking will depend somewhat on the kind of mushroom, the tastes of those that are to eat them and the conveniences at hand. Many of them can be cooked in the same manner as a beefsteak. It is customary to cook them in a very simple manner, either by frying in butter or broiling gently with a little butter added and seasoning to taste. They may also be stewed or baked. The skillful cook will devise many ways of cooking them and various recipes will be found in cook books and in works on edible fungi. Too much cooking may spoil a mushroom as well as an oyster or a tender beefsteak. My efforts to make a tough mushroom tender by steaming have not been successful, but the experiments have not been numerous nor long continued. Species too tough to be eaten with pleasure or digestcd with comfort have sometimes been utilized by making of them a kind of soup or broth which could be eaten with relish and comfort. Sometimes mushrooms are used in small quantity to give flaver to meats or other dishes. Those of inferior flavor are sometimcs made more agreeable by cooking with them a fer specimens of some more highly flavored species. The same species may vary in flavor according to the method of cooking and the kind of seasoning used as well as by reason of the circumstances previously mentioned.

Mushrooms may be dried and kept for future use. The best method of drying them is to place them in a current of warm air. Dry them as quickly as possible without burning them, and keep the drying process in operation till completed. A common fruit evaporator would doubtless be a good instrument for drying them. The drying of thick and moist ones would be facilitated by cutting them in slices.

The general opinion is that mushrooms constitute a very nutritious and sustaining diet. Chemical analysis and personal experience indicate this. The former has shown that in their dry matter they contain from twenty to fifty per cent. of protein or nitrogenous material. They may, therefore, well be called a kind of vegetable meat and be used as a substitute for animal food. Like other vegetables, they are largely composed of water, which is from eighty to ninety per cent. of the whole. In consequence of this they shrink greatly 
in drying and lose much weight. The presence of so much nitrogenous material induces rapici decay and loathsome decomposition in them. It should also teach moderation in their use as food. A hearty meal on mushrooms alone would be about as reasonab! $\epsilon$ as a dinner on nothing but beefsteak, and might be expected to be followed by similar ill consequences. Gormandizing is not commendable under any circumstances nor with any kind of food. But especially should it bo avoided in mushroom eating, for the human system demands but small quantities of the nitrogenous elements which enter into its composition. An excessive amount is sure to be hurtful, but eaten in moderate quantity it is easily digestible, acceptable and beneficial. The digestive organs of the writer are not strong by nature and are easily affected by unfavorable treatment or indigestible substances, yet he has never experienced any discomfort from eating mushrooms. He has eaten them frequently, partaken of many different species, and experimented with a considerable number of species not classificả as edible. The explanation is simple. They have always been eaten in moderate quantity. In my opinion, cases of sickness and digestive derangement that have been attributed to poisonous properties of mushrooms are sometimes really due to the excessive use of species that otherwise are perfectly harmless.

In some countries where edible fungi are commonly and axtensively employed as food, even species which we regard as unwholesome are utilized. They are soaked in vinegar or in salt water for the purpose of destroying or rendering inert their noxious properties. They are then carefully washed and thrown into hot water for a short time, after which they are treated in the usual way. This practice is not recommended. Aside from the danger arising from the inelliciency of the treatment in some cases, it is very improbable that any mushrooms so treated would still retain a very agreeable flavor. There is, besides, no need of running any risks with doubtful or suspected species, for the number of those known to be good and safo is sufficiently great to satisfy all reasonable demands. Possibly the time may yet come when the noxious properties of poisonous mushrooms may be utilized with advantage in medicine, but such species should not bo used as food. Ho who is too ignorant to recognize with contidence the species known to be good, would better abstain 
from such food entirely unless he can avail himself of the knowl. edge of some one who can recognize them.

A few edible fungi appear early in the season, but with us July, August and September are the months when the greatest variety is to be found. The morels occur in May and June. The Fairy-ring mushroom and the Glistening coprinus sometimes appear in June, and successive crops follow from time to time whenever the weather is favorable. During warm, showery weather in July and August most of our edible boleti are to be found.

A few of the species continue in September. The latter part of August and the first half of September will bring the Common mushroom and the Horse mushroom, the reather conditions being right. Excessively dry weather and prevailing cold weather are unfavorable to mushroom growth. Heat and moisture combined are farorable. It sometimes iappens when the fields and open country are too dry for mushroom growth, a scanty supply may be found in deep woods and shady swamps. It would be useless to look in such places for the Common mushroom and the Fairy-ring mushroom, for they do not grow in woods; but the Delicious lactarius, the Involute paxillus, the Rough-stemmed boletus and the Chantarelle may be found there. The Oyster pleurotus and the Sapid pleurotus may be found in woods or clearings at any time between June and October, provided there is sufticient rain to induce growth, but the Honeycolored armillaria, the Imbricated tricholoma, the Masked tricholoma and the Elm pleurotus will rarely be found before the last week in August or the first of September. Let no one expect to find the Granulated boletus, the Yellowish-brown boletus or the Small Yellowish boletus except in the immediate vicinity of pino trees or in places where pine trees have grown. These hints may be something of a guide to the inexperienced mushroom hunter. The dates and habitat given under the description of each species will furnish more full and definite information on this subject.

Before proceeding to the description of species it may be well to explain certain technical terms it may be convenient or necessary to use. For illustration of some of the following terms see Plate $A$ and its explanation. 
The substance of a mushroom takes tho name flesh though it is quite unlike animal fl ssh in texture and appearance. Most mush. rooms have an expanded part called the cap botanically known as the pileus. This is generally supported on a stem, but in the absence of a stem the cap is sessile. It varies much in shape in different species and even in the same species in different stages of development. In some mushrooms thin vertical plates or membranes radiate from the stem to the margin of the cap, or in the absence of a stem, from the point of attachment of the cap to its free margin. These are called lamelle or gills. Shorter ones intervene toward the margin of the cap to fill the spaces that would otherwise be left racant. The gills are attached by their upper edge to the lower surface of the cap and often by their inner extremity to the stem. They are aidnate when attached to the stem by the whole width of their inner extremity; adnexed when attached by a part of their width only; decurrent when they run down on the stem, gradually tapering to a point, and free when not attached to the stem. Sometimes their lower edge is notched or excavated at or near the stem, which fact is designated by the words emarginate or sinuate.

In some, the lower surface of the cap is full of small holes or cells, called pores. These aro so small in some species that they are scarcely noticeable but generally they are easily visible. They stand like tubes in a vertical position, side by side, with the openings or mouths downward. Theoretically they may bo supposed to be formed by numerous gills connected by frequent partitions or transverse membranes.

In still another group of mushrooms the lower surface of the cap bas neither gills nor pores, but instead there are numerous spino-like or awl-shaped projecting points called teeth. It is very mush as if closely placed gills bad been deeply, regularly and finely notched or gashed, but the teeth aro not arranged in regular radiating rows, as they would bo if actually formed in this way.

The upper surface of the cap is glabrous when it is smooth or free from hairs, fibrils or scales; even when it bas no pits, ridges or other inequalities; silky when adorned with soft, close-pressed fibrils; fibrillose if these librils aro harsher and looser; floccose 
when they are soft, short and collected in little flocs or tufts; tomentose when crisped and interwoven so as to form a woolly surface; squamose or scaly when coarse and collected in tufts, also when the cuticle breaks or cracks into small flakes or spotlike patches. These same terms are also applicable under the same conditions to the surface of the stem. The cap is also said to be umbonate when it has a small projection or boss on its center; umbilicate if it has a small central cavity or umbilicus, and hygrophanous when it has a soaked or watery appearance, the loss of which by drying is accompanied by some change in color. The margin of the cap is striate when marked by nearly parallel radiating lines. If these lines are very slight or are visible only in the moist or hygrophanous state the fact is indicated by the term striatulate.

The stem is equal or cylindrical when it is of uniform diameter in all its length; bulbous when moro or less abruptly enlarged at its base; stuffed when its interior or central part is of a softer or looser texture than the exterior. In some mushrooms a thin membrane, in others a mass of webby filaments, stretches from the stem to the margin of the cap and conceals the gills in the young plant, but as the cap expands, this membrane, called the veil, usually separates from the margin of the cap and adberes to the stem, forming around it a ring or collar, botanically known as an annulus.

In a fow species the young plant is wholly enveloped in a membranous or somewhat tomentose volva or wrapper, but this is soon ruptured by the growing plant and its remains are in some cases entirely lefi at the base of the stem, in others they partly adhere to the upper surface of the cap in the form of warts, or more rarely and exceptionally in a fer small irregular patches. The dangerously poisonous species occur in a gerius in which the volva is a prominent character.

The spores are the seeds or reproductive bodies of mushrooms. They are as fine as dust and are invisible to the naked eye except when collected together in great numbers or in masses. The hymenium is the surface or part of the plant immediately concerned in the production of the spores, and the hymenophore or hymenophorum is the part that supports the hymenium. In the Common mushroom and many others as well, the spores develop 
on certain specialized cells called brsidia (basidium in the singular) on each of which four spores usually develop. In the morels, these specialized cells are elongated into cylindrical membranous sacks called asci (ascus in the singular), in each of which eight spores usually develop. In germination the spores send out slender threads or filaments called mycelium by botanists, but commonly known as spawn. The mycelium permeates the soil or other substance on which the mushroom grows and under favorable circumstances derelops a crop of mushrooms of its own species.

The method and place of spore development furnishes the basis for the primary classification of fungi. The best way to acquire a lnowledge of our edible mushrooms is to study them in the light of tho primary characters employed in botanical classification and, therefore, in their natural relations to each other. It is my plan to arrange and describe them in their respective classes, families and genera. It will be seen that the species here described are all included in three great groups or classes, whose names and distinguishing characters may be expressed in the following general manner:

Gasteromycetex. Fungi whose spores are produced in the interior of the plant. Example. Puff balls.

Discomycetex. Fungi whose spores are produced on the upper or exterior surface of the cap and are contained in delicate membranous sacks. Example. Morels.

Hymenomycetex. Fungi whose spores are produced on the lower surface of the cap. Example. Common mushroom.

In the last class there are a fer species in which no cap is developed. In these the spores are produced on the exterior of upright simple stem-like plants, or of the branches of upright bush-like plants, or on the upper surface of jelly-like irregularly expanded plants. None of the gelatinous plants will be described and only a few species of the other exceptional cases. These species all belong to the singlo genus Clararia.

The spore-bearing surface, or hymenium, is generally recognizable, even to the naked eye, by its smooth, delicate, waxy appearance, which is quite unlike that of tho sterile surfaces.

In most of the cap bearing mushrooms the lower surface of the cap is furnished with special organs on whose surfaces the spores are produced. These are in the forms known as gills, 
pores and teeth, and these organs furnish the characters on which the three principal families of the Hymenomycetex are founded. These characters will be more fully discussed in their proper place.

\section{Gasteromyceteæ. Puff Balis.}

Puff balls belong to the class of fungi to which botanists have given the name Gasteromycetex. This name may be translated stomach fungi. It has reference to the fact that those plants which belong to this class have their stomach, that is, their whole interior, filled with spores when mature. The spores are developed on basidia as in the Hymenomycetex.

These are among the most easily recognized of fungi and the larger species in their early state are among tho best of our edible species. Almost every country lad is familiar with the globular plants with papery rind stuffed full of a mass of brown dust-like material intermingled with cottony filaments. Time and again these hare been seen lying on the ground or adhering to old stumps or the dead trunks of trees, and of ten bave they afforded amusement by being subjected to sudden pressure between thumb and fingers that there might be seen the little cloud of dust-like spores belched forth like a miniature puff of smoke, and like smoke quickly vanishing in the air. But no one would think these good to eat, nor indeed are they while in this condition. But most puff balls are white within when young and their substance is then of a soft fleshy texture very unlike the dusty mass that fills them in mature age. And it is only while they are white within that they are fit for food. When they reach maturity the flesh at first assumes greenish-ycllow or brownish-yellow hues and is apt to become moist or watery. They are then spoiled for edible purposes.

\section{Lycoperdon Tourn.}

Most of our puff balls and both the edible species here noticed belong to the genus Lycoperdon. There are about twenty species of this genus found in our State, but most of them are quite small, being less than two inches in diameter. They are naturally and botanically divided into two groups characterized by the manner 
in which they open for the dispersion of the spores. In one group the rind of the mature plant breaks into irregular fragmeats in the upper part of the plant, and gradually falls away exposing the mass of spores and permitting them to be disseminated by the wind. In the other group the rind opens by a small nearly circular but somewhat ragged apical aperture. This group includes nearly all of the smaller species, and the rind is generally thinner and more papery than in the others. Both the edible species here described belong to the first group. Some botanists have considered this group as worthy of generic distinction and have applied the name Calvatia to it, but for our present purpose the original names of the species are deemed preferable.

No deleterious species of puff ball is known, but so far as my experiments have gone the small species are inferior in flavor to the large ones, and these only are at present recommended for food. Possibly some of the untried small species may be as agreeably flavored as the large ones, and perhaps improved methods of cooking may gire a more agreeable dish from those already tried. We have two species of Bovista, a kind of puff ball differing slightly from lycoperdons in the more perfectly globular shape and in the more tough and smooth rind of the mature plant. These are the Lead-colored bovista, Bovista plumbea, and the Ball-shape borista, Bovista pila, both of which are pronounced edible by Professor W. Trelease, but as I have not tried them they are dismissed from further consideration at present.

The genus Scleroderma is allied to our common putf balls and would naturally bo classed with them in the popular mind. The species differ from puff balls in their thicker rind and in baving a colored flesh even in the immature state. I suspect that their disagreeable flaror has kept them out of the list of edible species, but one correspondent aflirms that he has eaten these fungi and considers them good.

The two species of puld ball now to be described may be contrasted as follows:

Plant 8 to 15 inches in liameter, spore mass olivaceous. I. giganteum. Plant 3 to 6 inches in diameter, spores mass purplish... L. cyathiforme. 


\section{Lycoperdon giganteum Batsch.}

Giant Puff Ball.

Plate 1.

Peridium very large, globose or depressed-globose, sessile or nearly so, glabrous or slightly flocculose, white, whitish or slightly yellowish, becoming dingy with age; capillitium and spores grecnish-yellow, then dingy-olivaceous; spores globose, about .00116 in. broad.

The Giant puff ball is our largest species. Its diameter is commonly eight to fifteen inches, but sometimes it attains even larger dimensions. Its horizontal diameter is often greater than its altitude. Its rind is smooth and white or whitish, but as it grows old it becomes yellowish and dusky. The flesh is at first white but with maturity it assumes greenish-yellow hues and when it becomes dusty it is brownish or brownish-olivaceous.

It grows in grassy places and appears in August and September. It is not common, but owing to its large size a single one is sufficient for a meal for a large family. Indeed one writer advises that, when one is found growing near the house, it should not all be taken at once, but that a sufficient quantity of it should be taken for a meal and another portion be cut from it the next day for another meal, and so on until it is all utilized or until it is too old for use. The largest specimens are apt to be depressed so as to resemble in shape a round loaf of bread.

\section{Lycoperdon cyathiforme Bose. \\ Cop-Shaprin l'UfF Batl. \\ I'linte:}

Peridium three to six inches in diameter, globose or depressedglobose, smooth or minutely floccose or scaly, whitish cinereous brown or pinkish-brown, often cracking into areas in the upper part, commonly with a short thick stem-like base; capillitium and spores purple-brown, these and the upper part of the peridium falling away and disappearing when old, leaving a cup-shaped base with a ragged margin; spores globose, rough, purple-brown, .0002 to .00025 in. broad.

The Cup-shaped puff ball is smaller than the Giant puff ball and more common. Ordinarily it is from three to six inches in diameter. It is at first white, whitish or brownish, but it is apt 
to become darker with age, assuming brown or pinkish-brown hues. The upper part of ten cracks into angular areas or patches, the chinks being paler than the surface. When fully mature the upper part of the rind breaks up into fragments which fall away revealing the dull purplish-brown mass of spores and filaments within. After these have disappeared there still remains a cupshaped base which is suggestive of the name of this puff ball and which sometimes persists all winter. From such an effete specimen the species was first named and described.

This species grows in pastures, sometimes in cultivated ground. It appears in August and September. In preparing it and the preceding species for tho table select immature specimens whose flesh is yet pure white. Peel them and cut the flesh into slices one-fourth to one-half an inch thick. These slices may be fried in butter and seasoned according to taste or they may first be dipped in bcaten egg and then fried and seasoned. In this way they make a kind of mushroom fritters or omelet that is liked by almost every one. If preferred, the beaten egg may be thickened with bread crumbs or crushed cracker. Some who are very fond of the Common mushroom fry the plain slices in butter, adding a mushroom or two to increase the true mushroom flavor, or they stew them in milk or cream, adding mushrooms if convenient, as before.

\section{Discomyceter.}

\section{Morelg, Helpellas and Mrtrula.}

The Discomycetex or disk fungi aro evidently so named because in many of the species the fertile or spore-bearing surface is flat like a disk. It includes also many cup-shaped fungi in which the fertile surface is concave like the inside of a saucer or cup. But in the group which contains the edible species here to be noticed the fertile surface is neither flat nor concare, but decidedly convex, conical, oval or even cylindrical or club shaped. In some species also it is rery irregular or uneven. In all the species, however unlike they may be in other respects, there is this agreement, the upper or exterior surface is the spore-bearing surface and the spores aro developed in thin membranous sacks, not on basidia within the plant as in the case of puff balls. In the morels and allied species the plant consists of a stem and cap as in an ordinary mushroom, but these are 
very unlike the stem and cap of a mushroom in general appearance. Our edible species are placed in four genera, whose prominent distinctive characters, so far as our species are concerned, may be ascertained from the following table:

Cap coarsely pitted over its whole surface ........... Mforchella.

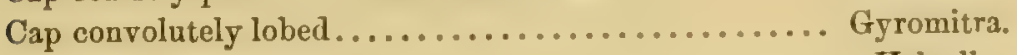

Cap irregular or reflexed .................... Helvella.

Cap club shaped, often irregularly so ............. Mitrula.

\section{Morchella Dill.}

In the genus Morchella, to which the morels belong, the cap is supported on a hollow stem and its whole surface is very uneven by reason of a net-work of anastomosing or reticulated ridges and their intervening carities. This gires the surface a pitted or honeycombed appearance. The ridges are blunt on the edge. The spore sacks are imbedded in the whole surface, both of pits and ridges, each sack usually containing eight spores, a fact which can only be ascertained for one's self by the aid of a microscope. In the mass, the spores are yellowish.

Six species bave been found in our State. All are similar in color, and the specific distinctions are not very sharp. They are found chiefly in the size and shape of the cap. All are deemed edible and similar in texture and flavor, and therefore the separation of the species from each other is not of much practical importance if they are sought for food only. The prevailing color of the cap in young and growing plants is buff-yellow or ochraceous, but as the plants become old or begin to dry, darker hues are assumed. The stems are rather stout, white or whitish, or barely tinged with yellow, and scurfy or at least not perfectly smooth and polished. They are hollow and in plants in which the margin of the cap is attached to the stem the cap also is hollow, the cavity being continuous between cap and stem.

The spccies may be arranged in two groups, in one of which the margin of the cap is wholly attached to the stem, in the other it is free.

All the species occur early in the season. They may be sought in wet weather, in May and June. I have never found any of them later than June. Most of them seem to prefer to grow under or near pine and ash trees, though they are sometimes found under other trees. 
There are two or three species of stink horn fungi, species of Phallus, which, when old, bear some resemblance to morels. They have a pitted cap supported on a stem, but the cap has an opening in the top and the stem is porous, and besides, these plants have such an intolerable odor that no one would think of eating them. It is not likely that any one would mistake them for morels.

In the annexed table the distinctive features of the species are indicated. All the species are so much alike that the usual botanical diagnosis will be omitted.

Margin of the cap united to the stem .......... I

Margin of the cap free frum the stem........... 3

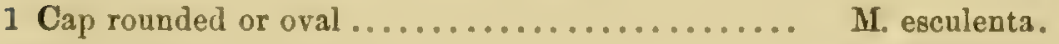

1 Cap oblong or cylindrical ................. M. deliciosa.

1 Cap conical or oblong-conical ............... 2

2 Cap distinctly broader than the stem.......... M. conica.

2 Cap scarcely broader than the stem.......... M. angusticeps.

3 Cap free from the stem to the middle.......... M. semilibera.

3 Cap free from the stem to the top............ M. bispora.

\section{Morchella esculenta Pers.}

Comion Morex.

Plate 3. Figs, 1 to 3.

In the Common morel the cap is generally a little longer than broad. It is sometimes nearly globose and sometimes slightly narrowed toward the top. The pits or depressions in its surface are rather broader than in other species and more rounded, thereby giving the surface an appearance more like that of a honeycomb.

The plant is commonly two to four inches high, with a stem a half inch or more thick.

It has long been known as an ediblo species, as its specific name implies.

\section{Morchella conica Pers. \\ Conical Morei. \\ Plate 4. Figs. 1 to 4.}

The Conical morel has the cap conical or oblong-conical, as its name indicates. The longitudinal ridges on its surface run more regularly from top to base than in the Common morel. 'They are connected by short transverse ridges which are so distant from each other or so incomplete that the resulting pits or depressions 
are generally longer than broad, and sometimes rather irregular. The color in the young plant is a beautiful buff-yellow or very pale ochraceous, but it becomes darker with age.

The plants are generally three to five inches high, with the cap one and a half to two inches thick in its broadest part, and distinctly bruader than the stem.

This is similar to the Common morel in its esculent qualities and is generally admitted by writers to be an excellent food and of delicate flavor. It has been regarded by some as a mere variety of the preceding species. Both may bo found growing on either sandy, gravelly or clayey soils.

Morchella angusticens Peck.

NARROW CAP MIOREL.

Plate 4. Figg. 5 to 9.

The Narrow cap morel differs from the Conical morel in its generally smaller size, more pointed cap and comparatively thicker stem. Generally the cap is scarcely thicker than the stem, even at its base, which is its broadest part. It is long and narrow and sometimes curved. In some specimens the stem is widest at the top and gradually tapers toward the base as shown in figure 5.

The plants are commonly two to three inches high, with the cap generally less than an inch broad in its widest part, but sometimes much larger specimens occur.

\section{Morchella deliciosa $F r$. \\ DeLictous Morei. \\ Plate 3, Figs, 4 to 7 .}

The Delicious morel is easily known by the shape of its cap, which is cylindrical or nearly so. Sometimes it is slightly narrowed toward the top and occasionally curved, as in the preceding species, but its long narrow shape and blunt apex is quite strongly contrasted with that species. It is usually two or three times as long as it is broad, and generally it is longer than the stem. Specimens also occur in which the cap is slightly more narrow in the middle than it is above and below, and rarely it is slightly pointed at the apex. The pits on its surface are rather narrow and mostly longer than broad. The stem is often rather short. 
The plant varies from one and a half to three inches high. It is a rare species in our State.

The name indicates that the illustrious Fries, who originally described the species, considered it an especially agreeable morel, and indeed he says it is more sapid than the Common morel. Roques sustains him in this opinion and Quelet speaks of it as very fine and fragrant.

In the four species already described the margin of the cap is united to or continuous with the top of the stem. In the two remaining species the margin of the cap is free from the stem, and consequently an open space intervenes between it and the stem.

Morchella semilibera $D C$.

HALF FREE MOREL.

Plate 3. Figs. 11 to 13.

The Half free morel has a conical cap, the lower half of which is free from the stem. It rarely exceeds an inch or an inch and a half in length, and is usually much shorter than its stem. Tho pits on its surface are longer than broad. Deformed specimens occur in which the cap is hemispherical and very blunt or obtuse at the apex; in others it is abruptly narrowed above and pointed.

The plants are two to four inches high. The species is rare with us.

Some writers claim that its flavor is less agreeablo than that of the Common morel. The plants are so scarce that I have had no opportunity to test its edible qualities.

The species was described by Persoon under the namo Morchella hybrida, a name having reference doubtless to the character of the cap, which, by being half free, partakes of the nature of the cap of an ordinary mushroom, while in other respects it retains the features of the true morels. This name is adopted in Sylloge Fungorum, but most linglish writers have employed the other.

\section{Morchella bispora Sor.}

TWo-sporen Motrel.

Plate 3. Figs. 8 to 10.

The Two-spored morel is very similar to the Half free morel in external appearance. It is distinguishable by its cap which is free from the stem almost or quito to tho top. 'The stem of the European plant has been described as stuffed, but in our plants it 
is hollow, though possibly in very young plants it may be stuffed. The remarkable and very distinctive character which gives name to the species, can oniy be seen by the aid of a microscope. In this species there are only two spores in each ascus or sack and these are much larger than the spores of the other species. They are two or three times longer and sometimes slightly curved. The spores of the other species are eight in an ascus and are very much alike in size and shape, and do not furnish decided specific characters; but in this species their importance can not be overlooked. Their length is about.002t inch, while in the others it is .0008 to .001 inch.

This is probably our rarest species. I am not aware that it has been found in but one locality in our State. A few years ago Mr. H. A. Warne detected it growing among fallen leaves in a ravine near Oneida. I have not tested its edible qualities, but would have no hesitation in eating it if opportunity should be afforded.

Some writers speak highly of the edible quality of the morels, others are less enthusiastic orer them. My own limited experience leads to the conclusion that, as a rule, they are not very highly flavored, though much better than some species classed as edible. One correspondent says, "I do not think much of morels. If cooked like mushrooms they become tough." And here, perhaps, is one cause of dissatisfaction with them. They may be spoiled by bad cooking. Some mushrooms are made more tough by too severe cooling. It is better to let such kinds simmer slowly over a gentle fire. One receipt for cooking morels says, cut clean morels in halves, placo in a stew pan with butter and set over a fire. When the butter is melted add a little lemon juice, salt and pepper. Then cook slowly for an hour, adding from time to time small quantities of beef gravy.

Cooke speaks of morels in general as about the safest and most delicious of edible fungi, and Cordier represents tho Common morel as a delicate food and one that is in general demand in France. There is one thing in favor of morels. They are generally free from insects, and on this account their natural flavor is unimpaired, and there is no loss from infested specimens. Their flesh is rather brittle or fragile and more dry than that of some mushrooms, in consequence of which they are easily dried for future use. 


\section{Gyromitra $F r$.}

The genus Gyromitra differs from Morchella in the character of its cap. The surface of this is not pitted as in the morels, but it is nevertheless very uneven, some parts being prominent as if inflated, others depressed. These convexities and depressions are so irregular and lobed that they suggest a faint resemblance to the convolutions of the brain. In other respects, and especially in the spore characters, the relationship to the morels is clear. Three species, Gyromitra esculenta, G. curtipes and G. spharospora belong to our State, but the first one only is common and known to be edible.

\section{Gyromitra escusenta $F r$. \\ Edible Helvelia. Esculext Gyomitra. \\ Plate 5. Figs, 1 to 3.}

Pileus rounded, lobed, irregular, gyrose-convolute, glabrous, bay red; stem stout, stulfed or hollow, whitish, often irregular; spores elliptical, binucleate, yellowish, .0008 to .0009 inch long.

The Edible helvella, formerly known as Ilelvella esculenta, is easily recognized by its chestnut red irregularly rounded and lobed cap with its brain-like convolutions. The margin of the cap is attached to the stem in two or three places. When cut through it is found to be hollow, whitish within and uneven, with a few prominent irregular ribs or ridges. 'T'he stem is whitish, slightly scurfy, and, when mature, hollow. In large specimens it sometimes appears as if formed by the union of two or more smaller ones.

The plant is two to four inches high and the cap commonly two to three inches broad. Specimens sometimes occur weighing a pound each. It is fond of sindy soil and is found in May and June. It grows chiefly in wet weather or in wet ravines or springy places in the vicinity of pine groves or pine trees.

Cordier says that this species has an agreeable taste and is highly esteemed. Also that it is sold in the German markets as a true morel. I have repeatedly eaten it without experiencing any evil consequences, but its flavor to me is not that of a first-class mushroom. But it was simply fried in butter and seasoned with salt. Perhaps with more elaborate preparation or with the addition of a little lemon juice or vinegar its flavor might be improved. 
Care should be taken by those eating it to use it with moderation and not to cook very old or long-kept specimens. Sickness has been known to result from eating freely of specimens that had been kept twenty-four hours before being cooked. Wher old and beginning to dry, the cap is apt to assume a darker or brown color. Often the lower or unexposed surface of the cap is paler than that which is more exposed to wind and sun.

\section{Helvella $L$.}

In the genus Melvella the cap is neither pitted nor convolutely lobed, but it is, nevertheless, quite irregular and variously reflexed, revolute or contorted so that in no two individuals, even of the same species, does it appear exactly alike. The stem in some species is stout and conspicuously marked by longitudinal grooves or furrows and their intervening ribs or ridges. In some species these furrows are continuous, in others, some of them are interrupted or short. In one or two species the stems are slender and even. All the species are rather small and scarce. They grow chiefly in woods and do not appear as early in the season as the morels and the Edible helvella. Though all are deemed edible I have not found them in sufficient quantity to verify their edible qualities and will describe onlv one of them.

\section{Helvella crispa $F r$. \\ WHITE HeLVELLA. \\ Plate 5. Flgs. 4 to 7.}

Pileus deflexed, lobed or variously contorted, whito or whitish; stem equal or slightly swollen at the base, deeply and interruptedly grooved, white or whitish; spores elliptical, .0007 to .0009 inch long.

The White helvella is distinguished from all other helvellas by its vhite or whitish color and by its peculiar stem, which is strongly ribbed and deeply grooved, the grooves or furrows being interrupted and varying much in length. A transverse section of the stem shows that it contains several longitudinal cavities or hollows. The cap is scarcely alike in any two individuals. Often it is lobed or contorted in such a way as to form two or more projecting points.

The plant is two to four inches high and the stem from onefourth to one-half an inch thick. It grows in woods in August and September, but is not often plentiful. 
Most French authors say that it is excellent when young, and Cooke says that when fresh it has a pleasant nutty tlavor and is an excellent substitute for morels. Badham also affirms that all helrellas are esculent and hare a general resemblance, in flaror, to morels. I do not know of any deleterious fungus that could reasonably be mistaken for this or any other helvella.

\section{Mitrula Fr.}

The genus Mitrula has been made by Saccardo in Sylloge Fun. gorum to include species having a club-shaped cap. In consequence of this enlargement of the generic character we find Geoglossum vitellinum Bres. and a variety of it, or a closely allied species, Geoglossum irregulare Peck, placed with the mitrulas. This pretty little fungus might easily be referred to the genus Clavama, but for the fact that its spores are contained in asci or sacks. Nor is it sharply separated from the genus Geoglossum except by its spore characters. The New York plant differs from the European in its more compressed and irregular cap, and in consequence it has been lept distinct as a variety, in Sylloge, and stands as

Mitrula vitellina Sacc. var. irregularis Pec

\section{IFRETULAR MITRELA.}

Plate 5. Figs. 8 to 14.

Pileus clarate, often irregular or compressed and somewhat lobed, obtuse, glabrous, yellow, tapering below into the short, rather distinct, yellowish or whitish stem; spores narrowly elliptical, .0003 to $.000 \pm$ inch long.

When the Irregular mitrula is well grown and symmetrical it closely resembles the typical European plant, but usually the clubs or caps are curred, twisted, compressed or lobed in such a way that it is ditlicult to find two plants just alike. Tho plants aro usually only one or two inches high, so that they would scircely be thought of any importance as an edible specics. But sometimes it grows in considerable profusion in wet mossy places in woods, so that it would not bo diflicult to gather a pint of them in a short time. Its beautiful bright yellow color makes it a rery attractive object. It is our largest species of 1 itrula and occurs in alutumn. 
It was first reported as an edible species in the Forty-second Report. Its flesh is tender and its flavor delicate and agreeable.

This plant was first described in 1879 in the Thirty-second Report, under the name Geoglossum irregulare. In 1882 Bresadola published his Geoglossum vitellinum, from which our plant differs so slightly that it has been considered a mere variety; and in consequence of the irregularity in the publication of the Thirty-second Report, no extra copies having been ordered, the later name has been given precedence.

\section{Hymenomyceteæ.}

\section{Mughroone, Boleti ano Famet Clubs.}

The mushrooms hereafter to be described belong to the very large class of fungi known to botanists by the name Hymenomycetex, a word composed of trwo parts, signifying membrane fungi, and in its present use indicaling that in these fungi the spores are produced on thin or membranous parts or surfaces. In the Common mushroom and in all others of similar structure, these spore-bearing membranes or surfaces are found on the lower or under side of the cap. They are commonly called gills, and have already been described. The spores are produced on both surfaces of the gills, and when mature they drop through the interspaces between the gills and fall to the earth below or are wafted away by currents of air. All fungi having a cap with gills beneath belong to the family Agaricinex.

In the Edible boletus and other fungi of similar structure the lower surface of the cap is full of small holes or pores, previously described. The spores are developed on the inner surface of these pores, and when mature they are dropped or ejected into the open air below. All fungi having a cap with pores beneath constitute a family called Poly porex.

In the Spreading hydnum or Hedgehog mushroom the lower surface of the cap is furnished with closely-placed depending spine-like teeth. All fungi of similar structure are included in a family named Hydnex, from the genus Hydnum, the principal genus in it. In one species the cap is replaced by spreading branches with teeth on their lower surface. Spreading or thinlyexpanded plants with no stems which belong to this and the preceding family are not noticed, since there are no edible species smong them. 
In the Cornucopia mushroom the cap has neither gills, pores nor teeth on its lower surface, which is even or slightly and obscurely wrinkled. It, therefore, belongs to a fourth family which takes the name Thelephorese.

There is still another family with a few edible species in it. It is named Clavariex, from its principal genus Clavaria. In this genus the edible species occur. It is composed of two kinds of plants. In one kind there is a simple upright club-shaped stemlike growth with no well-marked cap or expanded part. In the other there is a branching bush-like growth. In both these the spores are produced on the exterior surface of the plants or of their branches. A synoptical view of the five families is given in the annexed table.

Cap present.......................... 1

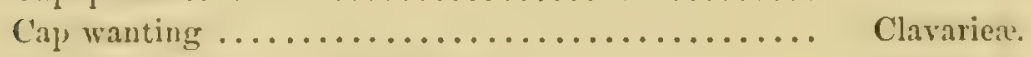

1 Cap with radiating gills beneath............... Agaricines.

1 Cap with pores beneath ................... Polyporex.

1 Cap with spine-like or awl-shaped teeth beneath...... Hylnex.

1 Cap with neither gills, pores nor teeth beneath...... Thelephorex.

Agaricineæ.

AgARICS.

The family Agaricinex probably includes more edible species than any other. Its members are sometimes called "agarics." More than 500 species of this family have been credited to our State flora. For the sake of convenience in the identification of such a great abundance of material, botanists have divided the fannily into smaller groups or sections depending on the color of the spores. We can do no better than to follow this arrangement in the study of the species. It is not a difficult matter to ascertain the color of the spores of an agaric. Generally they have nearly or quite the same color as the mature gills, but to this there are so many exceptions that to be exact we must see the spores themselves. Singly they are invisiblo to the naked eye, but when collected in a mass their color is plainly to be seen. If the cap of a mushroom is cut from its stem and placed in its natural position, gills downward, on any flat surface, say a piece of white paper as broad as itself, it will in a few 
hours drop enough spores on the paper to show their color, on removing the cap. If the spores are white, and we may infer that they are if the mature gills are white, white paper will not be so good for disclosing their color, as paper of some dark color. Black paper is sometimes used when it is suspected that the spores are white. Or the cap may be placed on a piece of glass and then the glass may be placed over a white or a colored background, according to circumstances.

Fresh, sound, fully-dereloped specimens should be selected to furnish the spores. If the cap is thin it is well to invert a goblet or similar vessel over it to prevent it from drying and to exclude currents of air.

Having ascertained the color of the spores the subjoined table will show in which section the species belongs.

Spores brown, purplish-brown or black........... Melanosporæ.

Spores ochraceous, brownish-ochraceous or rusty-ochra-

ceous ............................... Ochrospors.

Spores rosy or pinkish ................... Rhodosporx.

Spores white, whitish or pale yellow ............ Leucosporse.

\section{Melanosporæ.}

By some botanists the brown and purplish-brown-spored species are grouped in one section, and the black-spored species in another; but both are united in one section in Sylloge Fungorum and this is sufficiently simple for our purpose. Our edible species of this section are included in two genera, Agaricus and Coprinus.

\section{Agaricus $L_{\text {. }}$}

The genus Agaricus originally included nearly all the species that now compose the family Agariciner, but it has been divided and subdivided until now it includes only such brown-spored species as have free gills and a stem with a collar.

There are several edible species in the genus, and, so far as I know, it contains no dangerous species. The edible species are closely related to each other, and in all here noticed the gills have a pink color in young or middle age, but become darkbrown or blackish-brown in mature age. There is no simpler way of expressing the distinctive specific features than by an analytical table. The species may be arranged in two groups, 
depending on their place of growth. This arrangement is not as exact and satisfactory as is desirable, but it brings together those species that are most closely related to each other.

Plants growing in pastures, grassy or open

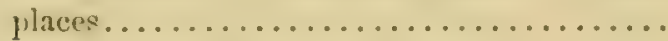

Plants growing in woods or groves.........

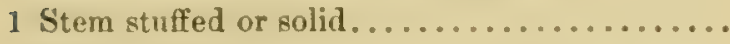

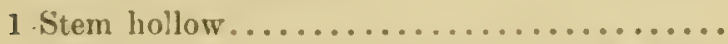

2 Gills at first pink, about as broad as the thickness of the cap ................

2 Gills at first white, breadth less than the thickness of the cap. ...............

3 Collar radiately divided on its lower surface..

3 Collar floccose on its lower surface .........

4 Flesh quickly changing to dull red where wounded .......................

4 Flesh not changing to dull-red where wounded ......................

5 Cap with numerous persistent brown seales...

5 Cap without scales or with fer evanescent ones.

A. campester.

A. Rodmani.

A. arrensis.

A. subrufescens.

A. hemorrhoidarius.

Agaricus campester $L_{0}$ *

Common Misirroom. Edible Musuroom.

Plate 6.

Pileus silky or squamulose; lamelle at first a delicate pink, becoming brown or blackish-brown with age; stem stuffed, glabrous, white or whitish; spores elliptical, .00025 to .0003 inch long.

The Common mushroom, sometimes called the Edible mushroom, as if it was the only edible species known, and also Meadow mushroom in common with $\Lambda$. arvensis, is perhaps more generally used and better known than any other. It is the one commonly cultivated and the one most often seen on the tables of the rich and of fashionable restaurants and public houses. It is so eagerly sought in some of our cities that it is dillicult to find the wild ones near these towns, for they are gathered almost as soon as they appear, and the cultirated ones usually bring prices beyond the reach of the poor.

- This name is usually written Agaricus campestris, but in 8ylloge Fungorum the more clasical and grammatical term here adopted is used. 
In very young plants the cap is hemispherical or almost globose and the gills are concealed. Such plants of this and of the closely related Horse mushroom have received the name "button mushrooms," and are preserved in brine or other liquid and sold in the leading grocery stores. As the cap expands the veil separates from the margin revealing the delicate-tinted pinkish gills. When mature the cap is very broadly convex or nearly flat. It is generally a little silky with close-pressed fibrils, but these often vanish with age and the cap appears quite smooth. Its margin, especially in the younger plants, extends a little beyond the exterior extremity of the gills. The color of the cap is commonly white, but with age it may become a little tinged with dingy hues. The flesh is white, but sometimes exhibits a tendency to become slightly tinged with red when cut and exposed to the air. Its taste is mild and pleasant. The epidermis is separable from the cap.

The gills are closely placed, rounded at the inner extremity and not attached to the stem. The beautiful pink hue of their early. state gradually becomes darker and tinally changes to a smoky brown, which, in dried specimens, becomes almost or quite black. This peculiarity in the coloration of the gills is so unlike anything known in the dangerous species that it seems surprising that any such should erer be mistaken for this mushroom. A whole group of pink-spored species, some of which are suspected of being hurtful, have pinkish-colored gills, but they never assume dark-brown or blackish hues.

The stem is generally shorter than the horizontal diameter of the cap and about equal in thickness from top to base. The cen. tral portion is a little softer in texture than the external part. A collar encircles it in the upper part. Sometimes this is so thin and slight that scarcely any vestige of it remains in old plants.

The spores are sometimes described as purplish-brown but I have never been able to see any decided purple tint in them. They are not as dark as seal-brown but approach it.

This mushroom, like many other plants that have been long and extensively cultivated, has developed into several forms which exhibit quite well-marked distinctive features. One of these, called the Garden mushroom, Variety hortensis, is represented by figures 8 and 9 . It is often found in cultivation and 
sold in the markets, but is rarely found growing in the fields. Its cap is of a brownish color and frequently adorned with darker spots or scales.

Variety grisens has a grayish shining silky cap. I bave not yet found it in New York, but it grows in Virginia. It occurs in France and is figured by Richon and Rozé.

Variety alba has the cap and stem white. It is our most common form.

Cap two to four inches broad, stem one and a half to three inches long, one-third to tro-thirds of an inch thick.

The Common mushroom grows in grassy places, in pastures, manured ground and mushroom beds, never in thick woods. It occurs mostly in August and September. In cultivation in a suitable place it may be had in midwinter. Owing to the attacks of insects it is better to raise mushrooms in winter than in summer, unless the insects can be effectually excluded from the beds and the apartments and the temperature properly regulated. The wild ones are thought by some to have a better flavor than the cultivated ones, but the latter are good enough for any one and sometimes command surprisingly high prices. Mushrooms of all kinds are more eagerly sought and more extensively used in Europe than in this country, but with the great influx of Europeans into this country, bringing with them a taste for this kind of food, and with the rapid increase in population making an increased demand for all kinds of food, it is probable that the demand for and the use of mushrooms will soon be as great here as in Europe. The chief difticulty in the matter is the lack of a sulficient general knowledge of the species or of the means of acquiring the knowledge necessary to malie it safe to use them.

In the wild state the Common mushroom usually grows in groups or a single one in a place, but when cultivated they often form large tufts. A kind of out-door cultiration is sometimes employed in order to increase the abundance of mushrooms. Nerglected places in fence corners, pastures or roadsides are dug up and manure incorporated in the soil if it is not already very rich. Musbroom spawn, after having been soaked in warm water or kept moist in a warm placo for several hours to start it into growth, is then planted in the prepared plices and a coat of line manure spread over the surface. 
It is well to mulch the surface with some coarse material like leaves, straw or hay, to keep the soil moist. If the planting is done in spring and the season is favorable a crop of mushrooms should appear in autumn.

Almost every cook claims to know how to prepare this mushroom for the table, and recipes for cooking it will be found in cook books. No extended directions therefore are necessary here. One of the simplest methods and one which is applicable to all tender species is to fry gently in butter, seasoning according to taste. They may be stewed in milk or cream, broiled on a gridiron or in a steak broiler, or baked in an oven. To some they are very acceptable when eaten raw. Doctor Cooke says that when abroad on a day's excursion, one or two of these raw specimens are an excellent substitute for sandwiches, as they satisfy hunger, are nutritive and digestible, and very pleasant and grateful to the palate.

\section{Agaricus Rodmani Peck.}

\section{Rodman's Mushrooy.}

Plate 8. Figs, 1 to 6.

Pileus rather thick, firm, glabrous, white or whitish, dingyyellow or reddish-yellow in the center, flesh white, uncbungeable; lamello crowded, narrow, at first whitish, then pink, finally blackish-brown; stem short, solid, whitish; spores broadly elliptical, .0002 to .00025 inch long.

Rodman's mushroom may easily be mistaken for the common mushroom to which it is closely related. It has been separated from it because of its comparatively thicker firmer flesh, its more narrow gills, which are almost white when very young, and its peculiar collar. This seems to be double, and in the mature plant the two parts separate in such a way as to leave a deep groove or channel between them. In rery short-stemmed specimens the collar is situated so near the base of the stem that it appears much like the remains of the volva or wrapper in some species of Amanita. The spores are a little shorter and broader in proportion to their length than those of the Common mushroom, so that at first sight they seem to be nearly globose.

The cap is two to four inches broad, the stem one to two inches long and one-half an inch or less in thickness. 
This mushroom was first described and recorded as edible in the Thirty-sixth Report. Subsequently Richon and Rozé published a species found in France to which they gave the name Psalliota duriuscula, the Firm champignon. They speak of their plant as a suspected species with nothing to recommend it, with an unpleasant flaror and with a flesh so hard as to render it indigestible. The figure and description of their species indicate that it is not distinct from Rodman's mushroom. But Mr. Rodman ate of his plant and found it perfectly harmless. It is, therefore, classed as edible. I have had no opportunity to test its edible qualities, but would have no hesitation in eating it if $I$ could find it in good condition.

It grows in grassy ground and even in crevices of unused parements and pared gutters in cities. It appears from May to July. I have not found it in autumn. It is rare.

\section{Agaricus subrufescens Peck.}

\section{Slightut reddisi Mushroom.}

Plate 7.

Pileus at first deeply hemispherical, becoming convex or broadly expanded, silky fibrillose and minutely or obscurely squamulose, whitish, grayish or dull reddish-brown, usually smooth and darker on the disk, flesh white, unchangeable; lamellio at first white or whitish, then pinkish, finally blackish-brown; stem rather long, often somewhat thickened or bulbous at the base, at first stuffed, then hollow, white; the annulus flocculose or floccosesquamose on the lower surface; mycelium whitish, forming slender branching root-like strings; spores elliptical, .00024 to .00028 inch long.

The Slightly reddish mushroom differs especially from the Common mushroom in the peculiar deeply hemispherical shape of the cap of the young plant, in the white or whitish color of the rery young gills, in the at length hollow stem, often somewhat thickened or bulbous at the base, and in the collar, which has the exterior or lower surface covered with little downy flakes or scales. Beside these characters it has others which may aid in supporting its claim to specific distinction. Its mycelium scems strongly disposed to form strings which adhere to the baso of the stem like white branching thread-like roots, and the flesh has a flavor like that of almonds. This flavor 
appears to me to be more pronounced in the older plants than in those that are very young. When raised in large quantities in greenhouses it sometimes gives out a perceptible odor of bruised almonds.

The reddish-brown color is due to the coating of fibrils that cover the cap. These are often collected in minute tufts, which give a slight floccose or scaly appearance to the cap. In the center the epidermis does not separate into fibrils and scales, and in consequence the disk or center of the cap is smoother and more distinctly reddish-brown than the rest. The flesh is white and unchangeable when cut or broken. In this respect it differs decidedly from the Reddish variety of the Common mushroom, Variety rufescens, though it resembles it in having the very young gills white.

The stem is generally rather long and more or less thickened at the base. It is white and usually slightly flocculose below the collar, very smooth above it. In the mature plant it is hollow, but the cavity is very small. One of the distinguishing features of the species is the flocculent cr scaly lower surface of the veil or collar. It is apparently a double membrane, as in the Field mushroom, but instead of the lower membrane breaking in a radiate manner as in that species, it breaks into small floccose flakes or scales. By this character and by the color of the very young gills it may be separated from the Garden variety of the Common mushroom, Variety hortensis, which it approaches in the color of the cap.

The plant often grows in large clusters of many individuals, one correspondent affirming that as many as forty individuals sometimes occur in one cluster. In size it is similar to the Common mushroom, but under favorable circumstances it seems sometimes to excel it, the cap attaining a diameter of six inches.

It has been found but once in a wild state within our limits. Mr. Wm. Falconer, of Glen Cove, Long Island, discorered it growing on his compost heap composed chiefly of decaying leaves. From some of these specimens kindly sent me by the discoverer the original description was derived, but the specimens were not in satisfactory condition to figure. The present illustrations have been made from specimens kindly furnished by Colonel Wright -Rives of Washington, in whose greenhouse an 
enormous rolunteer crop developed in soil prepared for forcing cucumbers. The species is apparently more easy of cultivation than the Common mushroom, less subject to the attacks of insects and not so intolerant of unfarorable conditions. It is very productive, derelops sooner after the planting of the spawn and probably will keep longer in good condition. Specimens picked in Washington on Monday night, reached Albany in a good state of preservation on the Thursday following, and some of them were eaten for supper on that day, making an interval of three days and three nights between the picking and the eating, and proving the possibility of supplying a distant market with this mushroom. Its flesh does not seem to me quite as tender as that of the Common mushroom, and its almond-like flavor may not be as acceptable to some tastes, but it is nevertheless an excellent mushroom and one which may yet supersede the old kind, especially in the hands of private individuals who are often disappointed in their efforts to raise mushrooms.

Agaricus arvensis Schaff:

Field Musiroom. Horse Musuroom. Plate 8.

Pileus smooth or at first slightly flocculent, white or yellowish; lamella at first whitish or very faintly pinkish, soon dull pink, then blackish-brown; stem stout, hollow, somewhat thickened or bulbous at the base, white, the collar double, the upper part membranous, white, the lower part thicker, subtomentose, radiately split, yellowish; spores elliptical, .0003 to .0004 inch long.

The Field mushroom or IIorse mushroom, also called Meadow mushroom, is so much like the Common mushroom that some botanists have supposed it to bo a mere rariety of that species. The most notable differences are its larger size, its hollow, somewhat bulbous stem, its peculiar veil or collar and the paler gills of the very young plant. The cap in dried specimens is apt to assume a yellow color, which does not pertain to the Common mushroom. The collar appears to be composed of two parts closely applied to each other and making a double membrane, the lower part of which is of a thicker, softer textureand split in a stellate manner into broad yellowish rays. This is perhaps the most distinctive character of the species, and a more detailed 
description is scarcely necessary. No serious harm could come, so far as utility is concerned, if it should be confused with the Common mushroom.

It grows in cultivated fields, grassy pastures and waste places. It is occasionally found under trees and even within the borders of thin woods. It has been supposed by some that its spores will not germinate unless they have passed through the alimentary canal of some animal. Whether there is any truth or not in such a supposition, it is common enough to find this musbroom growing in places where no trace of the dung of animals can be seen. It appears from July to September.

A similar mushroom occurs in open places in woods or along the borders of thin woods. The color of its cap and stem is white as in the Field mushroom. Its cap is perhaps a little thinner and more fragile, and its stem is usually longer and has a very abrupt or flattened bulb at its base. Its collar is usually the same as that of the Field mushroom, but plants sometimes occur in which it appears to be a single lacerated membrane. Such plants have been referred to the Wood inhabiting mushroom, Agaricus silvicola; but its general attinities seem to mo to connect it more clusely with Agaricus arvensis, to which I would subjoin it as an abrupt variety, Variety abruptus, tho namo having reference to the character of the bulb. I have eaten of this variety and consider it edible. Dried specimens assume a yellowish hue.

Opinions differ concerning the esculent qualities of the Field mushroom. According to Lerkeley it is inferior to the Common mushroom, and Badham says its flavor and odor are strong, and it is generally shunned by English epicures. On the other hand, Persoon says it is superior to the Common mushroom in smell, taste and digestibility, and it is, therefore, generally preferred in France. Vittadini also says it is very delicate and easy of digestion, but has a stronger odor than the Common mushroom. "Very sapid and very nutritious," "odor feeble, but flavor aniselike and very agreeable," "delicious when young and fresh, but tough when old," are opinions expressed by various writers. One author says it is edible and of exquisite flavor, and both these expressions have been perpetuated in two of the synonyms of the species, Agaricus edulis Kromh. and Agarious exquisitus Vitt. 


\section{Agaricus placomyces Peck. \\ Fluat oap Mughroom. \\ Plate 9. Fygs. 7 to 12.}

Pileus thin, at first convex, becoming flat with age, whitish, brown in the center and elsewhere adorned with minute brown scales; lamellac close, white, then pinkish, finally blackish-brown ; stem smooth, annulate, stuffed or hollow, bulbous, white or whitish, the bulb often stained with yellow; spores elliptical, .0002 to .00025 in. long.

The Flat cap mushroom is a rare but a beautiful species. Its cap is convex or somewhat bell-shaped when young, but when mature it is nearly or quite flat. Its brown center and its numerous minute brown scales on a whitish background give it a very ornamental appearance. It becomes darker with age.

Its gills, which in the very young plant are white or nearly so, pass through the usual shades of pink and brown with advancing age.

The stem is rather long and swollen into a bulb at the base. It sometimes tapers slightly toward the top near which it bears a thin flabby membranous collar. It may be either stuffed with a pith or bollow. It is white or whitish, but the bulb is sometimes stained with yellow.

Cap two to four inches broad, stem three to five inches long, one-fourth to nearly one-half an inch thick.

It grows in the borders of hemlock woods or under hemlock trees from July to September. It has been eaten by Mr. C. L. Shear, who pronounces it very good. I have not found it in sufli. cient quantity to give it a trial. This mushroom is very closely related to the Wood mushroom or Silvan mushroom, Agaricus silvaticus, a species which is also recorded as cdible, but which is apparently more rare in our State than eren the Flat cap mushroom. This differs from the Silran mushroom in its paler color, in having the cap more minutely, persistently and regularly scaly, and in its being destituto of a prominent center. In the Silvan mushroom the scales, when present, aro fow, and they disappear with age.

IIaving had no opportunity to make the drawings of the Bleeding mushroom, Ayaricus hemorrhoidarius, and of the Silvan 
mushroom, Agaricus silvaticus, and not having tested their edible qualities, they are, for the present, dismissed from further consideration.

\section{Coprinus Pers.}

The genus Coprinus is easily distinguished from all others by the character of the gills of the mature plant. These assume a black color and slowly dissolve into an inky fluid which, in the larger plants at least, falls to the ground in drops. The thin caps of some species also partly or wholly waste away in this manner. Because of the production of this black fluid, which has sometimes been used as a poor substitute for ink, these plants have received the name "inky fungi." In a few species the spores are brown, but generally they are black. Some of the plants literally grow up in a night and perish in a day. Many of the species inhabit dung or manure heaps, as the generic name implies. Most of them are so small, thin and perishable that they are not valuable as food. Even the larger ones have thin caps, and those deemed edible should be gathered when young and cooked promptly if used as food. Three species are here noticed.

Cap whitish ...................... C. comatus.

Cap grayish or grayish-brown................ atramentarius.

Cap buff-yellow or tawny-yellow ........... C. micaceus.

Ooprinus comatus Fr.

Suatitir Coprinis.

Plate 10.

Pileus at first oblong or nearly cylindrical, becoming campanulate or expanded and splitting on the margin, adorned with scattered yellowish scales, whitish; lamellx crowded, white, then tinged with red or pink, finally black and dripping an inky fluid; stem rather long, hollow, smooth or slightly fibrillose, white or whitish, at first with a slight movable annulus; spores elliptical, black, .0005 to $.0007 \mathrm{in}$. long.

The Shaggy coprinus, or Maned agaric as it is sometimes called, is one of the largest and finest species of the genus. When young the cap is quite long and sarrow, but with adrancing age the margin spreads outward, becomes split in several places and curves upward. The surface is adorned with loose fibrils and with scales or spots which appear to be due to the breaking up 
of an epidermis which remains entire in a small patch on the very top of the cap. Except the top and the scales the cap is white, but in mature plants it often becomes sordid or blackish toward the thin margin as if it were stained or soaked by the inky fluid formed from the gills.

The gills at first are closely crowded together and white, but soon pinkish, reddish or purplish tints appear, which quiclily change to black. Sometimes all these hues may be seen at one time in one plant.

The stem is white, smooth and hollow. In the young plant it is furaished with a collar which is morable or but slightly adherent. It is easily destroyed and has often disappeared at maturity.

The cap is one and a half to three inches long before expansion. The stem is three to five inches long and one-fourth to one-third of an inch thick. It grows in rich loose earth by roadsides, in pastures, waste places or dumping grounds. It appears in autumn and may sometimes be found quite late in the season. It is quite fragile and must be handled with care. It is very tender and digestible and scarcely inferior to the Common mushroom in flavor, though some think it is improved in flavor by cooking a mushroom or two with it. It is fit for the table only before the gills have assumed their black color, but even after that it is sometimes used in making catsup.

"When young it is very sapid and delicate;" "cooked quickly in butter with pepper and salt, it is excellent;" "edible, tender and delicious;" "in flavor it much resembles the Common mushroom, to which it is quite equal, if not superior; it is clearly more digestible and less likely to disagree with persons of delicate constitutions," are opinions recorded in its favor.

\section{Coprinus atramentarius 1 r}

InkY Coprinus.

Plate 11. Fige, 7 to 11

Pileus at first ovate, becoming expanded, glabrous or with a few obscure, spot-like scales in the center, grayish-brown; lamellx crowded, at first whitish and flocculose on tho edge, then black; stem glabrous, hollow, white or whitish; spores elliptical, black, .0003 to $.000 t$ in. long. 
The Inky coprinus is much less attractive in its appearance than the Shaggy coprinus. Its cap is quite smooth except on the disk, which is sometimes spotted with a few obscure scales. The color is grayish or grayish-brown, sometimes with a slight suggestion of lead color. The margin is sometimes irregularly notched or lobed.

The gilis are at first crowded and whitish, but they soon become black and moist and gradually dissolve away, forming an inky dripping fluid which is suggestive of the name of the species, and which may be used as ink.

The stem is rather slender, smooth and hollow. It sometimes has a slight vestige of a collar near the base, but it soon disappears.

The cap varies from one to three inches or more in diameter, the stem is two to four inches long, one-sixth to one-third of an inch thick.

It grows in clusters in rich soil, in gardens, waste places or in woods, and appears in late summer or in autumn. The form growing in woods is generally smaller and more beautiful than that growing in open places. It may be called var. silvestris.

The cap sometimes appears as if suffused with a bloom. It deliquesces rapidly and it is, therefore, more available for catsup than for food. If intended for the table it must be cooked as soon as brought to the house. In Europe both this and the preceding species appear in spring as well as in summer and autumn, but I have not seen them early in the season in our State.

\section{Coprinus micaceus Fr.}

\section{Guistrining Coprines.}

Plate 11. Figs. 1 to 6.

Pileus thin, at first ovate, then campanulate or expanded, striate, sometimes glistening with shining particles when young, buff-yellow or tawny-yellow; lamellæ crowded, whitish, then tinged with pinkish or purplish-brown, finally black; stem slender, fragile, hollow, white; spores elliptical, brown, .00025 to .0003 in. long.

The Glistening coprinus is a small but common and beautiful species. Its cap is somerwat bell-shaped and marked with impressed lines or striations from the margin to or beyond the 
middle. The center is smooth and often a little more highly colored than the rest. The glistening particles which are suggestive of the name of this little mushroom are not of ten noticeable, and when present on the young cap they often disappear with age. The margin is frequently notched or lobed and wary and it is apt to become split as the cap expands. The color varies from a pale whitish buff to tawny-yellow or reddish-ochraceous. It becomes sordid or brownish in old age, especially if wet or water-soaked.

The gills, as in the preceding species, are at first crowded and whitish, but they soon change color, becoming pinkish tinted and then brown and black.

The stem is slender, fragile, smooth, hollow and white. The brown color of the spores is unusual in this genus.

Cap one to two inches broad, stem one to three inches long, rarely thicker than a pipe stem.

The Glistening coprinus grows in clusters on the ground or on decaying wood. It occurs from May to Norember. It appears in wet weather and sometimes seems to anticipato rain, starting to grow two or three days before a rain storm. Sereral successive crops often come up about a single old stump in one season. When a cluster appears to grow from the ground it is quite probable that it really starts from some decaying root or other piece of wood buried in the earth. It is not uncommon to find it growing from places in the margin of the siderrallis of our cities where shade trees have been cut down, the decaying stump and roots furnishing the necessary habitat. In such cases the boys of the street delight in kicking tho clusters to pieces and stamping them out of existence, thinking probably that they aro abundantly justified in destroying a vilo toadstool which might otherwise be the means of poisoning some one. These tufts are sometimes very large and composed of very many plants closely crowded together. Sometimes the caps crack into small areas, the whito flesh showing itself in the chinks.

European writers do not record the Glistening coprinus among the edible species, perhaps because of its small size. But it compensates for its lack of size by its frequency and abundance, and it has the adrantage of being easily and frequently procurable. In tenderness and delicacy it does not appear to mo to be at all 
inferior to the Shaggy coprinus, and it certainly is harmless, for it has been eaten repeatedly by various persons and always without ill results. It was published as edible in the Twenty-seventh Report.

\section{Ochrosporæ.}

Members of this section may be known by the ochraceous hues of their spores. The color may tary somewhat, being ochraceous, rusty-ochraceous or brownish-cchraceous in different species. The recorded edible species occur in three genera, Pholiota, Cortinarius and Paxillus. No species of the first genus has been proved by me.

\section{Cortinarius Fr.}

Of the genus Cortinarius, eight species have been classed as edible by English writers. Four of these occur in our State, and three of them have been tried. The genus contains many species, and it is almost certain that several others will yet be found to be esculent. The genus is distinguished especially by the rustyochraceous color of the spores and by the webby character of the veil. In the young plant fine webby filaments stretch from the margin of the cap to the stem, and in many species these are so numerous that they at first conceal the gills, but they mostly disappear with advancing age and leare little or no traco of a collar on the stem. In some instances a few filaments adhere to the stem and afford a lodgment for the falling spores, in consequence of which a rusty-brown stain or ill.defined band of color is seen on the upper part of the stem.

In young plants the color of the gills is generally quite unliko that of mature ones. In these the gills become dusted by the spores and assume their color, so that there is great uniformity in the color of the gills of mature plants in all the species. It is, therefore, of the utmost importance in identifying species of Cortinarius to know the color of the gills of the young plant. In all the species they are attached to the stem at their inner extremity, and generally they are emarginate. Most of the species grow in woods or groves or along their borders, and are especially found in late summer and autumn in hilly or mountainous regions. 
The three species here described may be tabulated as follows:

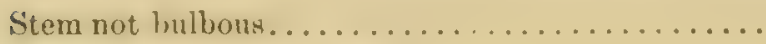

Stem with a bulbous base ................ C. violaceus.

1 Cap viscid or glutinons when moist........... C. collinitus.

1 Cap not viscid, dry and fibrillose............. C. cinnamomeus.

\section{Cortinarius violaceus $F r$. \\ Tiulet Cortinarius. Plato 12.}

Pileus convex, becoming nearly plane, dry, adorned with numerous persistent hairy tufts or scales, dark violet; lamellix rather thick, distant, rounded or deeply notched at the inner extremity, colored like the pileus in the young plant, brownishcinnamon in the mature plant; stem solid, fibrillose, bulbous, colored like the pileus; spores subelliptical, .0005 in. long.

The Violet cortinarius is a very beautiful mushroom and one easy of recognition. At first the whole plant is uniformly colored, but with age the gills assume a dingy ochraceous or brownish-cinnamon hue. The cap is generally well formed and regular and is beautifully adorned with little hairy scales or tufts. These are rarely shown in figures of the European plant, but they are quite noticeable in the American plant and should not be overlooked. The flesh is more or less tinged with violet.

The gills when young are colored like the cap. They are rather broad, notched at the inner extremity and narrowed toward the margin of the cap. When mature they become dusted with the spores whose color they take.

The stem also is colored like the cap. It is swollen into a bulb at the base and sometimes a faint rusty-ochraceous band may be seen near the top. This is due to the falling spores which lodge on the webby filaments of the veil remaining attached to the stem.

Cap trio to four inches broad, stem three to five inches long, about half an inch thick.

The Violet cortinarius grows among fallen leares in the woods of our hilly and mountainous districts, in July and August. I have never found it in the open country. It is solitary or scattered in its growth and not very plentiful. Nevertheless it is a very good species to eat, and when botanizing in tho extensive 
forests of the Adirondack region it afforded an excellent and very much relished addition to our bill of fare. It retains something of its color when cooked, and in consequence a dish of Violet mushrooms is scarcely as attractive to the eyes as to the palate.

\section{Cortinarius collinitus $F r$. \\ Smaked Cortinarids. Plate 13. Figs. 1 to 6.}

Pileus convex, obtuse, glabrous, glutinous when moist, shining when dry; lamellw rather broad, dingy-white or grayish when young; stem cylindrical, solid, viscid or glutinous when moist, transversely cracking when dry, whitish or paler than the pileus; spores subelliptical, .0005 to .0006 in. long.

The Smeared cortinarius is much more common than the Violet cortinarius and has a much wider range. Both the cap and stem are covered with a viscid substance or gluten which makes it unpleasant to handle. The cap varies in color from yellow to golden or tawny-yellow and when the gluten on it has dried it is very smooth and shining. The flesh is white or whitish. The young gills have a peculiar bluish-white or dingy-white color which might be called grayish or clay color, but when mature they assume the color of the spores. They are sometimes minutely uneven on the edge.

The stem is straight, solid, cylindrical and usually paler than the cap. When the gluten on it dries it cracks transversely, giv. ing to the stem a peculiar scaly appearance.

The cap is one and a half to three inches broad, and the stem two to four inches long and one-fourth to one-half inch thick.

The plant grows in thin woods, copses and partly-cleared lands and may be found from August to September.

It is well to peel the caps before cooking, since the gluten causes dirt and rubbish to adhere tenaciouslv to them.

\section{Cortinarius cinnamomeus $F r$. \\ Cinnamon Cortinariug. \\ Plate 13, Figj. 7 to 20.}

Pilous thin, convex, obtuse or umbonate, dry, fibrillose at least when young, flesh yellowish; lamellæ thin, close, adnate; stem slonder, equal, stuffed or hollow; spores elliptical, .0003 in. long. 
The Cinnamon cortinarius is smaller than either of the foregoing species, but it is more abundant. It is quite variable in size, shape and color. The cap is generally convex at first, but often expands until it is nearly 1 lat. Sometimes it has a central prominence or umbo. It is more or less coated, at least when young, with minute silliy fibrils, but sometimes becomes smoothish with age. Its color is commonly cinnamon-brown, brownish-ochraceous or tawny-brown. The gills are some shade of yellow when young, except in one variety, but when mature they assume the color of the spores. The stem is rather slender, often flex. uous, fibrillose or silky, stuffed or hollow when old, and yellowish or colored like the cap, or a little paler.

In tho Ialf-red variety, Variety semisanguineus, figures 15 to 20, the young gills have a dark blood-red color. This perhaps ought to be considered a distinct species.

The cap is usually one to two inches broad, the stem one to three inches long and one-fourth of an inch thick or less. The plant grows in woods or their borders, under trees or in mossy swamps. Like many flowering plants which hare a wide range and are not particular as to their habitat, this mushroom is perplexing becauso of its variability, but it is believed that the doscription and figures here given will make it recognizable. The fresh plant often has a slight odor like that of radishes.

\section{Paxillus Fr.}

The genus Paxillus is characterized by its gills which are easily and smoothly separable from the cap just as the tubes of a Boletus are, from the cap that supports them. They are reticulately connected at the base in the single species here considered. The spores are ochraceous.

\section{Paxillus involutus Fir. \\ Involute Paxillos. \\ L'Jate 23. Wigs. 18 to 23.}

Pileus compact, convex at first, soon expanded and centrally depressed, nearly glabrous, grayish-buff or ochraceous-brown or yellowish ferruginous, the margin in rolute and when young covored with a grayish tomentum; lamella close, decurrent, branched and reticulately connected behind, whitish, then yellowish or sub. forruginous, changing to reddish-brown where cut. or bruised; 
stem central or eccentric, solid, glabrous, colored like the pileus ; spores elliptical, .0003 to .0004 in. long.

The Involute paxillus is somewhat variable in color and exhibits a strange admixture of gray, ochraceous, ferruginous and brown hues, sometimes one being more prominent, sometimes another. It is apt to bo viscid when moist and shining when dry. The margin is rolled inwards in the young plant, and is adorned with a grayish tomentum or villosity. It sometimes exhibits short markings as in figures 20 and 21 . The flesh is not a clear white, but tinged with gray.

The gills are at first whitish, but they become yellowish or rust colored with advancing age and assume brownish or reddish.brown stains where cut or bruised. They are decurrent and a little wary and reticulately connected where they run down on the stem. The interspaces between them are marked with reins.

The stem is generally shorter than the diameter of the cap and solid. It is colored nearly like the cap and is sometimes adorned with a few darker spots.

Cap two to four inches broad, stem one to three incheslong, one-third to one-half an inch thick.

The Involute paxillus grows in woods either on the ground or on decayed wood. It grows singly or in groups and seems to like damp mossy soil well filled with vegetablo matter. It is common in cool hemlock or spruce woods, but occurs also in mixed woods, and along the borders of marshes. When growing on old decayed stumps or the prostrate moss-covered trunks of trees the stem is sometimes eccentric, but in other cases it is generally central. It appears from August to November.

It is sometimes called the Brown chantarelle, but it is scarcely a rival of the true chantarelle. Nost authors record it as edible but they do not praise it highly Richon and Rozé say it is edible but scarcely to be recommended. Letellier on the other hand says it can be employed as food with much advantage. It is also said to be held in high estimation in Russia. With us it is scarcely available except to people living near damp woods or sivamps.

Rhodosporæ.

The name of this section, which in some works bears the name IIyporhodii, indicates that the spores are red, but their color is 
really a peculiar pinkish or rosy bue commonly described as flesh color or salmon color. It is a combination of ochraceous and pink. The mature gills usually hare this color. Only a few species of this section are known to be edible and some have been thought to be unwholesome. There are several genera, but the species here considered belong to one only.

\section{Clitopilus Fr.}

The species of this genus are separable from all others of the section by their fleshy stem and decurrent gills. Mushrooms of similar structure occur in the genus Clitocybe which belongs to the section characterized by white spores. Their gills also are generally white in the mature plant. The pink-gilled species need not be confused with the Common mushroom and those of its relatives that have the gills of a pink color while young, for in them the pink color is soon replaced by brown or blackishbrown, but in these the gills retain their pinkish hue and never assume darker colors. Besides, in the Common mushroom and its allies the gills are not attached to the stem by their inner extremity, but in the species of this genus they are. Many species, not of this genus only but also of other genera in this section, have the gills white or whitish in the young plant, but with advancing are they assume the more permanent pinkish hue.

\section{Clitopilus prunulus Scop. \\ Plum Clitolifes. \\ Plate 14. Figs. 1 to 6.}

Pileus fleshy, compact, broadly convex or nearly plane, sometimes centrally depressed, dry, suffused with a bloom, whitish or grayish, the margin sometimes wavy; lamellx somewhat distant, decurrent, at first whitish, becoming salmon colored; stem glabrous, solid, white; spores oblong elliptical, pointed at each end, $.000 \pm$ to .04045 in. long.

The Plum clitopilus is not a common species with us, and when it does occur it is not in abundance. Its cap is white or whitish inclining to grayish with the center sometimes decidedly darker than the margin. It is dry and firm and often seems to be corered with a bloom. Its llesh is whito and the plant has an odor like that of meal. 
The gills are at first nearly white but they assume a pale-pink or salmon color with age. They run down on the stem.

The stem is solid, smooth and white.

Cap two to three inches broad, stem one to two inches long, onefourth to one-half an inch thick. This plant is found in woods in warm wet weather in July and August. It is solitary or there are but few individuals in a place. English writers speak highly of it as an esculent, and class it among the most delicious of edible species. Gillet says that it is one of the best mushrooms that can be found.

\section{Clitopilus orcella Bull.}

\section{Swerturead M[conoour.}

Plate 14. Figs. 7 to 11.

Pileus fleshy, soft, brozdly convex or nearly plane, generally irregular and wavy on the margin, silly, white or yellowishwhite; lamellæe close, decurrent; stem short, solid, flocculose, sometimes eccentric; spores oblong-elliptical, pointed at each end, .00035 to $.0004 \mathrm{in}$. long.

The Siveetbread mushroom is so much like the Plum mushrocm that it is not surprising that they have been regarded as forms of one species. The differences indicated in the descriptions trould make the Sweetbread mushroom generally a little smaller and less regular, the flesh softer, the cap slightly riscid in wet weather and a clearer white, and the gills a little closer together. Intermediate forms seem to connect the two supposed species, and however interesting the differences may be to botanists, the mushroom eater will scarcely try to keep the two forms separate. Both have the farinaceous odor and are not very different in taste. Some have considered the Sweetbread mushroom as slightly superior in the delicacy of its flavor. Both are good enough. The Sweetbread mushroom sometimes grows in pastures and open places. Miss Banning sometimes finds it growing in rings after the manner of the Fairy-ring mushroom. She finds some plants with the usual strong new-meal odor, others with but little odor and all with a flavor suggestive of cucumbers.

\section{Leucosporæ.}

The Leucosporæ or white-spored agarics are distributed among many genera. The species are more numerous than in any other 
section and many of them are edible. On the other hand, our most dangerous species occur in this section. The spores are generally white, as the name of the section indicates, but in a few cases they have a dingy or sordid-white hue, and in several species they are pale-yellow. In one or two species not found within the limits of our State they have a green color, but these are not yet recorded as edible species. In one mushroom the spores assume a pale-lilac tint after a brief exposure to the air and light. Pale-yellow spores occur especially in the genera Cantharellus, Lactarius and Russula.

Our edible species are found in about a dozen genera. The subjoined analytical table will serve to indicate the leading characters of each genus and may be used as a guide or an aid in tracing any species to its proper genus.

Plant with a membranous sheath at the base of the stem or with superficial warts on the cap........

Plant destitute of such sheath and warts ..........

1 Stem furnished with a collar ................ Amanit

1 Stem destitute of a collar .................. Amanitopsis.

2 Gills narrow, obtuse on the edge............. Cantharellus.

2 Gills acute on the edge ................... 3

3 Gills somewhat waxy in texture ............ Hygrophorus

3 Gills not waxy in texture ................. 4

4 Cap eccentrically or laterally attached to the stem or stemless....................... Pleurotus.

4 Cap centrally attached to the stem........... 5

5 Gills free from the stem .................... Lepiota.

5 Gills attached to the stem.................. 6

6 Stem furnished with a collar .............. Armillaria.

6 Stem destitute of a collar ................. 7

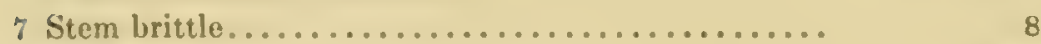

i Stem not brittle .........................

8 Gills exuding a white or colored juice where

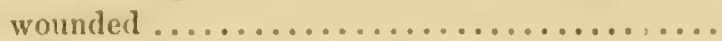

8 Gills exuding no juice where wounded..........

9 Dry plant reviving on the application of moisture...

9 Plant putrescent, not reviving on the application of

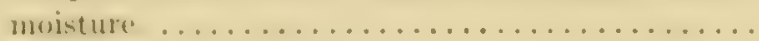

10 Edge of the gills notehed or excavated at the stem

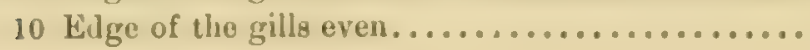

Iactarius.

Russula.

Marasmius.

'Tricholoma.

Clitocybe. 
Amanita Pers.

In the genus Amanita the very young plant is enceloped in a membrane or a tomentose irapper which is ruptured by the growth of the plant. In some species the remains of the ruptured wrapper persist about the base of the stem, forming a kind of cup or sheath; in others, a part of the wrapper is carried up on the surface of the cap and adheres to it in small irregular patches or in the shape of numerous small warts or prominences which are easily separable from it. It sometimes happens that these superficial warts are washed off by heavy rains. 'I'he cap in most of the species is regular and broadly convex or nearly flat when mature, and in some instances it is slightly sticky or viscid when moist. The gills are free from the stem and the stem is furnished with a membranous collar. These plants are generally large and attractive in appearance. Inasmuch as our most dangerous species belong to this genus it is very important that the specific characters of the edible ones should be thoroughly understood by those who would use them for food. Mlistakes here are attended with too much risk to be lightly made. Some would counsel the rejection of all species of Amanita because of the presence in it of some poisonous ones; but it would be as reasonable to say we will eat no parsnips because the poison bemlock belongs to the same family, or no potatoes, tomatoes or egg plant because the deadly night shade is closely related. The only thing necessary is the ability to separate the good from the bad in one case just as we do in the other.

\section{Amanita cæsarea Scop.}

\section{Orange Amanita.}

Plate 15.

Pileus glabrous, striate on the margin, red or orange, fading to yellow on the margin; lamellix yellow; stem annulate; loosely sheathed at the base by the ruptured membranous white volva, yellow ; spores elliptical, white, .0003 to $.000 t$ in. long.

The Orange amanita is a large, attractive and beautiful species. When very young the cap and stem are contained in a white membranous envelope or wrapper not very much unlike a hen's egg in size, shape and color. As the parts within develop, the 
wrapper ruptures in its upper part, the stem elongates and carries upward the cap, while the remains of the wrapper surround the base of the stem like an open sack or loose sheath. The cap is at first red or orange, but with advancing age it fades to yellow on the margin. Sometimes the whole cap becomes yellow. In dried specimens the red color often wholly disappears. The margin, even in the young plant, is marked by distinct impressed parallel radiating lines or striations. The flesh is white but more or less stained with yellow under the separable epidermis and next the line of attachment of the lamella or gills. Its taste is mild and pleasant. As in most of our other species of Amanita, the cap, when fully expanded, is nearly flat above, and when moist its surface is slightly sticky or viscid.

The gills are rounded at the extremity next the stem and are free, that is, not attached or grown fast to the stem. They are yellow, and in this respect are unlike the gills of nearly all the other edible species of mushrooms here described. Generally the color of the gills in the mature plant resembles the color of the spores of that plant, but in this species we have an exception.

The stem and the flabby membranous collar that surrounds it toward the top are yellow like the gills, though sometimes they are stained in places by darker or saffron-colored hues. The stem of the young plant contains in its center a soft cottony substance or pith, but with advancing age this disappears and the stem is hollow. This character generally holds good in all the species of Amanita here described. In the rery young plant the outer edge of the collar is attached to the margin of the cap and thereby it covers and conceals the gills, but with the elongation of the stem and the expansion of the cap, the collar separates from the margin and remains attached to the stem only.

The expanded cap is usually three to six inches broad, the stern four to six inches long and a half inch or more in thickness. Sometimes these dimensions are exceeded.

'The plant grows chiefly during rainy weather or just after heavy rains, in July, August and September. It is found in thin woods and seems to be especially fond of pine woods and a sandy soil. It is not common. It sometimes grows in rings or in the arc of a circle. 
This fungus has been held in high estimation as an article of food from very ancient times. It was used by the Greels and Romans and having graced the table of a Roman emperor it received the name "Cresar's mushroom," whence the botanical name. One ancient writer terms it "Cibus Deorum," the food of the gods. Imperial mushroom, Orange mushroom, true Orange, Yellow-egg and Kaiserling are other names applied to it.

All authors who have written concerning its esculent qualities agree in characterizing it as "delicious." Cordicr says that it is an exception to the general rule that young plants are better for food than those fully grown. The inference is that the mature individuals are just as tender and sapid as the young ones. I have not tested this point. No charge or even suspicion of noxious quality seems to have been entertained against it in any case.

There is but one harmful species with which it is possible to confuse the Orange amanita. It is the Fly amanita, Amanita muscaria. These two resemble each other in size, shape and color of the cap, but in other respects they are quite distinct. The chief distinctive characters may be contrasted as follows:

Orange amanita. Cap smooth, gills yellow, stem yellow, wrapper persistently membranous, white.

Fly amanita. Cap warty, gills white, stem white or slightly yel. lowish, wrapper soon broken into fragments or scales, white or yellowish.

In Europe there is said to bo a variety of the Orange amanita with the cap wholly white or whitish, but no such variety has yet been recorded in this country.

\section{Amanita rubescens 17 .}

\section{Redish Amanita.}

Plate 16.

Pileus warty, even or but slightly striate on the margin, more or less tinged with dingy-red or brownish-red hues; lamella white or whitish; stem annulate, bulbous at the base, whitish, but generally with dull reddish stains, especially toward the base; spores elliptical, .0003 to .00035 in. long.

The Reddish amanita has a peculiarly sordid and uninviting appearance, owing to the dingy character of its colors. The 
wrapper which covers the young plant soon breaks up into small fragments, those on the cap being carried up with it in the growth of the plant and generally remaining on it in the form of small wart-like protuberances. The part remaining behind at the base of the stem is so fragile and fleeting that nearly ail traces of it soon disappear, and were it not for the warts on the cap and the free lamella the plant would scarcely be suspected of being an Amanita. The warts on the cap aro easily removable and are sometimes washed off by rain, leaving the cap entirely smooth. The margin of the cap is generally even, but sometimes, especially in fully matured individuals, it is more or less striated. While the color is peculiarly dull and sordid it varies considerably. The cap may be whitish tinged with pink or red, brownish-red or dingy grayish-red. Sometimes it is not uniformly colored but has the margin paler than the center, or there may be darker stains in some places. The flesh is white or slightly tinged with red. Sometimes wounds of the flesh, gills or stem slowly assume a dull rerldish color, but this is not a constant character.

The stem has a membranous collar near the top and a bulb at its base. In some cases this bulb is quite abrupt, in others it is po inted below and gradually narrowed into the stem abore. The surface of the stem may be smooth in some plants, but generally it is more or less adorned below the collar with mirute scales or mealy or branny particles. It is commonly of a whitish or dingy-white color, more or less stained with dull-red, especially toward and at the base. The center of the stem is of a looser, softer texture than the rest, and in mature plants it sometimes becomes hollow.

Cap three to five inches broad, stem three to six inches long, and generally about balf an inch thick.

It grows either in woods or in open places, and may be found from July to September.

The Reddish amanita, as found in New York, is generally of a paler color than that indicated by most of the published figures of the species. Frequently the cap is almost white, with but a slight reddish or brownish-red tint. The strong distinguishing character of the species is the almost entire absence of any remains of the wrapper at the base of the stem. By this and by 
the presence of the dull-red hues and stains it may be distinguished from any of our poisonous species.

Some writers have referred to this species as of doubtful quality, suspected character or as poisonous, but later authors agree in classing it with the edible species. According to Cordier it is largely used in the eastern part of France, and is one of the most delicate mushrooms. Gillet agrees with him in this opinion. Cooke says it is pleasant both in taste and smell, and is a very common, safe and useful species. Stevenson records it as delicious and perfectly wholesome.

\section{Amanitopsis Roze.}

The principal feature wherein the genus Amanitopsis differs from Amanita is in the absence of a collar from the stem. Its species were formerly included in Amanita. We have one ediblo species.

\section{Amanitopsis vaginata Roze.}

\section{Sheathed Asanitopsig.}

Plate 17.

Pileus rather thin, fragile, glabrous or adorned when young with one or more adhering fragments of the rolra, deeply and distinctly striated on the margin; lamella free, white or whitish; stem destitute of an annulus, sheathed at the base by the torn remains of the rather long, thin, flabby volva; spores globose, white, .0003 to $.000 \pm$ in. broad.

The Sheathed amanitopsis is distinguished from any species of Amanita by the absence of a collar from the stem.

In this plant the cap is quite smooth except in rare instances in which one or two fragments of the ruptured wrapper adhere to it for a time. The striations on the margin are deep and distinct, as in the Orange amanita. The cap is quite regular, but it is fragile and easily broken. In some instances a slight blunt protuberance or umbo develops at its center. It varies considerably in color, and several varieties depending on this variation have been described.

The flesh is white, but in the darker-colored forms it is grayish under the separable epidermis. 
The gills are white or whitish and are gradually more narrow toward the stem. The stem is often smooth but generally it is sprinkled with minute mealy or branny particles or floccose scales, especially in young and vigorous specimens and in the darkcolored forms. It is either hollow or stuffed with a cottony pith. It is not bulbous, but it is sheathed at the base with a soft, flatby, torn membrane, the remains of the wrapper. This adheres so slightly to the stem that if the plant is carelessly pulled the sheath is left in the ground.

The cap is two to four inches broad; the stem, three to five inches long and one-fourth to one-half an inch thick.

The plant grows singly or scattered in woods or in open places. It is common in the deep damp regetable mold of dense erergreen woods in mountainous regions, but is not limited to such localities. It is found in almost all parts of the State and on a great variety of soil. It sometimes grows on much decayed wood. It occurs from June to October.

In the white variety, Variety alba, the whole plant is white. This is A. nivalis (Grev.) and A. fungites (Batsch.).

In Variety fulva, A. fulva (Schxff) tigures 1 to 4, the tarny variety, the cap is tawny-yellow or pale ochraceous.

In the livid variety, Variety livida, the cap has a livid or leaden-brown color and the gills and stem are more or less tinged with a smoky-brown hue. This is A. livida and A. spadicea (Pers.). See figures 5 to 9.

Some of the older authors placed the sheathed mushroom among the doubtful or suspected species, but more recent writers generally admit that it is edible. My own experience indicates that it is scarcely first class, though some pronounco it "delicate," "delicious," Btc.

\section{Lepiota $F r$.}

'I'ho species of Lepiota hare the gills typically free from the stem, as in Amanita and Amanitopsis, but they differ in having no superficial or removable warts on the cap, and no sheathing or scaly remains of a wrapper at the base of the stem. In somo species the epidermis of the cap breaks into scales which persistently adhere to the cap, and this feature, indeed, suggests the name of the genus, which is derived from the Latin word lepis, a scale. 
Our State is farored with at least two very good edible species, both of which are easily recognized, if the generic characters are kept in mind.

Cap scaly, umbonate.................... L. procera.

Cap smooth, not umbonate................ L. naucinoides.

\section{Lepiota procera Scop. \\ Parasor Mighhroom. Tall Leprota. \\ Plate 18.}

Pileus thin, umbonate, adorned with brown spot-like scales; lamellix white or yellowish-Twhite, free, remote from the stem; stem very long, annulate, hollow, bulbous; spores large, elliptical, .0005 to .0007 inch long.

The Parasol mushroom is a rery neat, graceful and attractive species. When young the cap is brownish or reddish-brown and somervhat resembles an egg in shape. Its reddish-brown epidermis soon breaks up into numerous fragments, and as the cap expands these become more and more separated from each other, except on and near the central boss or umbo. As the cap is paler beneath the epidermis it appears, when expanded, to be variegated by brown spots or scales. The paler surface has a somewhat silky or fibrillose appearance, minute librils radiating from the center toward the circumference. The cap sometimes becomes fully expanded, but usually it maintains a convex form like an opened umbrella or parasol. This form, together with the prominent umbo and the long slender stem, is very suggestive of the common nume of this fungus. The flesh is soft, dry, slightly tough and white. It has no unpleasant odor or flavor.

The gills are whitish or slightly tinged with yellow. They are elosely placed side by side, narrower toward the stem than toward the margin, and their inner extremity is so far from the stem that a conspicuous clear space is left about it.

The stem is very long in proportion to its thickness and is, therefore, suggestive of the specitic name procera. It has a rather thick, firm collar, which in the mature plant generally becomes loosened and morable on it like a ring. At the base it swells out and forms a bulb. Generally the part below the collar is variegated by numerous small brownish dots or scales, but these are by no means a constant character. The stem is hollow or it sometimes contains a soft cottony or webby pith. 
Cap three to five inches broad, stem five to ten inches long, one-fourth to one-half an inch thick.

This plant grows in thin woods, in fields and pastures and by roadsides. It usually grows singly or scattered, but sometimes in clusters. It may be found from July to September, but, unfortunately, it is not very common with us.

The Parasol mushroom has been highly commended and is evidently a first class edible species. "One of the most delicate species, although the flesh is slightly tough," "almost the greatest, if not the greatest, favorite with fungus eaters," "very delicate, of easy digestion and in great demand," are some of the recorded utterances in its favor.

There is no poisonous species with which it can beconfused or for which it can be mistaken. The very tall slender stem with its bulbous base, the peculiarly spotted cap with its very prominent darker colored umbo, and the broad space or basin about the insertion of the stem and between it and the inner extremity of the gills, easily distinguish this mushroom.

There is a form in which the umbo and spot-like scales are paler than usual, and the whole plant, except these, is white. I regard it as a mere variety of the species. A form without an umbo and with a somerwat shaggy appearance to the cap has been found in the western part of the State. It closely resembles the Ragged lepiota, Lepiota rhacodes, a species which is also edible. Our plant, however, differs from the description of $L$. rhacodes in having larger spores; these being scarcely smaller than those of the Parasol mushroom. It is the opinion of some botanists that $L$. procera and $L$. rhacodes are forms of one species, so closely are they related, and in Massee's Fungus Flord the latter is considered a mere variety of the former.

\section{Lepiota naucinoides $P k$.}

\section{Shocth Lhpiota.}

Plute 19.

Pileus soft, smooth, white or smoky-white; lamella free, white, slowly changing with age to a dirty pinkish-brown or smokybrown color; stem annulate, slightly thickened at the base, colored like the pileus; spores subelliptical, uninucleate, white, .0003 to .0004 in. long. 
The Smooth lepiota is generally very regular and symmetrical in shape and of a pure white color. Rarely the central part of the cap is slightly tinged with yellow or with a smoky-white hue, which is occasionally dark enough to be called smoky-brown. Its surface is nearly always very smooth and even. In rare instances a slight mealiness or granular roughness develops on the central part of the cap. A very unusual form sometines occurs in which the surface of the cap is broken into rather large thick scales which give it a singular appearance. To this form the name Variety squamosa has been applied.

The gills are a little narrower toward the stem than they are in the middle. At the inner extremity they are rounded and not attached to the stem. They are white or slightly tinged with yellow until maturity or old age when they acquire a slight pinkish-brown or even a smoky-brownish color. In dried specimens this last color prevails.

The stem has about the same color as the cap. It has a white collar of which the external edge is generally thicker than the inner. It sometimes breaks loose from its attachment to the stem and becomes a movable ring upon it as in the Parasol mushroom. Occasionally in old specimens it becomes torn and disappears entirely. Nearly always the stem gradually enlarges toward the base and forms a more or less distinct bulb. It is hollow, but as in most of the preceding species, the carity often contains webby or cottony filaments, especially in the immature plants.

Cap two to four inches broad, stem two to three inches long, one-fourth to one-half an inch thick.

The Smooth lepiota grows in grassy places in lawns and pastures or by roadsides. Rarely it is found in cultivated fields, and even in thin woods. It may be found from August to November.

In my estimation this species is scarcely, if at all, inferior in its edible qualities to the Common mushroom. Its flesh is thick and white and usually tender and savory. It is very free from the attacks of insects and growing, as it often does, in places where the grass is short and dense, it has a neat, clean and attractive appearance. Its gills retain their white color a long time, and in this respect it has an advantage over the Common mushroom, 
in which they soon pass from the delicate pink of youth to the repulsive blackish hue of age. One of my correspondents in speaking of this species says "it grows abundantly here and is one of our finest edible musbrooms. I have taught our people to eat it and it is now highly prized in this region."

It being similar to the Common mushroom in size and color it is sometimes confused with that species. But a glance at the color of the gills is sulficient to separate the two. The color of the spores and the character of the stem and collar are also distinguishing differences. It still more closely resembles the Challiy mushroom, Agaricus cretaceus, but the darker color of the gills and the brown color of the spores of that species will also abundantly distinguish it. Our plant is apparently the American representative of the European Lepiota naucina, to which it was formerly referred, and from which it scarcely differs except in the shape of its spores and in its smoother cap. The spores are described by Fries as globose in the European plant. All the species here mentioned are edible, so that discrimination between them would not be necessary for safety in using any of them for food. It is, however, more satisfactory always to recognize without any doubt the species used for food. Our figures and descriptions will enable any one to do so. The Smooth lepiota was first recorded as edible in the 'I'wenty-serenth Report, where it stands under the name Agaricus naucinus.

\section{Armillaria $F \dot{r}$.}

The species of Amillaria differ from all the foregoing white spored species in having the gills attached to the stem by their inner extremity. Like them their spores are white and the stem has a collar, but there is no wrapper at the base of the stem as in Amanita and Amanitopsis. By the collar the genus differs from the other genera which follow.

\section{Armillaria mellea Vuhl.}

Honey-colomen Armileaira. Plate: $: 0$.

Pileus adorned with minute tufts of brown or blackish hairs, sometimes glabrous, eren or when old slightly striate on the margin; lamellix adnate or slightly decurrent, whito or whitish, 
becoming sordid with age and sometimes rariegated with reddish-brown spots; stem annulate, at length brownish toward the base; spores elliptical, white, .0003 to .000t in. long.

The Honey-colored armillaria is very plentiful and extremely variable. The cap is generally adorned with numerous minute tufts or scales of brown or blackish hairs, which are often more dense on the disk or center than toward the margin. In young plants they are often so crowded on the disk as to cover it and gire it a darker hue than the margin has, and they sometimes are so fine and matted that they hare a kind of woolly or tomento e appearance. In some forms of the species they are entirely wanting, or they disappear with age. The cap is sometimes charged with moisture, and as this eraporates the color becomes slightly paler. Its color varies from almost white to a dark red. dish-brown, which is shown in figure 4 . The most common hue is a brownish-yellow shown in the lower figures of the plate. The margin of the cap in mature plants is commonly striated. but forms are not rare in which no striations appear. 'The center of the cap is sometimes prominent, as in figure 3. The flesh is white or whitish and its tasto is somewhat unpleasant or acrid.

The gills are at first white or whitish, but with age they become less clear in color and are often more or less stained or spotted with reddish-brown. The inner extremity of those that reach the stem is attached to it and usually runs down slightly upon it. Sometimes there is a slight noteh on the lower edge of the gills near the stem.

The stem is alorned with a collar which may be membranous or of a thick cottony texture, or so thin and webby that it entirely disappears in the older plants. Externally the stem is rather firm and fibrous, but centrally it is soft and spongy or even hollow. It varies considerably in color, but usually it assumes a reddish-brown or livid-brown bue, especially toward the base, remaining paler above. Sometimes a yellow ish green tomentum is noticeable at the base of the stem, and occasionally on the collar. The stem may be of uniform thickness or slightly thickened at the base or even narrowed almost to a point here In one variety it has a distinctly bulbous base, in another a tapering base like $a$ tap root which penetrates the earth deeply. 
Cap one to six inches broad, stem one to six inches long, onefourth to three-fourths of an inch thick.

The Honey-colored armillaria is very common and grows either in woods or in cleared land, on the ground or on decaying wood. A favorite habitat is about stumps and prostrate trunks in recently cleared places or in bushy pastures. Its mode of growth is either solitary, gregarious or in dense tufts or clusters. Tufts a foot in diameter and composed of twenty or more plants are not uncommon. The plants are especially abundant in hilly and mountainous districts in autumn. They rarely appear plentifully before the first of September, though occasional specimens have been seen as early as June.

Monstrous forms sometimes occur, and there is an abortive form which consists of a whitish irregular rounded mass of cellular matter without any distinction of stem cap or gills. This usually grows in company with the ordinary form, and is an inch or two in diameter. The mycelium of this fungus is thought to be destructive to the wood in which it grows. Probably most of the plants which appear to grow on the ground really take their rise from mycelium which permeates some fragment of wood or some root buried in the ground. It attacks both the hard woods and soft woods.

Authors disagree concerning its edible qualities. Some of the older authors considered it poisonous, but modern writers gen. erally agree that it is harmless and edible, but of inferior quality. Cordier says it is edible and loses its acridity in cooking, but the stems are tough and not used.

Richon and Rozé affirm that its taste is astringent and that its acridity does not entirely disappear in cooking, but that it is edible though of indilferent quality.

According to Vittadini, it is preserved in vinegar, salt and oil for use in winter, and its acridity is lost in cooking. Gillet also says that in reality it is harmless, though it las an acrid, disagreeable taste, which disappears in cooking. "Esculent but not commendable," is the verdict of Berkeley: "edible but tough," says Stevenson, while Cooke tells us that it is very common and much used on the Continent, but is not recommended.

My own experience in eating it at various times, both fried and stewed, has always been without any harm. Cooking has 
appeared to me to dispel the unpleasant taste of the raw plant, but sometimes when the dish was prepared by stewing in milk and water, a slight, unpleasant burning sensation was felt in the throat a short time after eating. I consider it a perfectly safe and edible species, but not of first quality. Only the caps of young and fresh specimens should be used.

It is not improbable that such a variable plant as this may vary somewhat in flavor. We do not expect all varieties of apples to have exactly the same flavor, though the species may be one. The degree of toughness, too, may vary according to the age and the rapidity of the grow th of the plants. Individual tastes may also differ, so that what would please one might be distasteful to another. Such facts may account, in part, at least, for the varying opinions concerning the edible qualities of this very common mushroom. The essential thing to know is, that the species is not dangerous. Then those who like it may eat it.

The following varieties of this species may be noted:

Variety obscura has the cap covered with numerous small blackish scales.

Variety flava has the cap yellow or reddish-yellow, but in other respects it is like the type.

Variety glabra has the cap smooth; otherwise like the type.

Variety radicata has a tapering, root-like prolongation of the stem, which penetrates the earth deeply.

Variety bulbosa has a distinctly bulbous base to the stem.

Variety exannulata has the cap smooth and even on the margin, and the stem tapering at the base. The annulus is rery slight and evanescent or wholly wanting. The cap is usually about an inch broad, or a little more, and the plants grow in clusters, which sometimes contain forty or fifty indiriduals. It is more common farther south than it is in our State, and is reported to be the most common form in Maryland.

Notwithstanding the variability of the species, it is easily recognized when its characters are once known. I do not know of any dangerous species which could easily be mistaken for it

The abortive form which often grows with it, is not distinguishable from the abortive form of Clitopilus abortivus. It has a farinaceous taste which is lost in cooking. It is not inferior to the normal form in flavor, and may be eaten with safety. 


\section{Tricholoma Fir.}

The species of Tricholoma, and all the white-spored, gill-bearing fungi to be hereafter described in these pares, differ from all the preceding species in haring no collar on the stem. In this genus the gills are attached to the stem, and are excarated or notched on the edge at or near the stem. It often happens that this notch is so near the extremity of the gill that the part attached to the stem is more narrow than the gill just beyond the excavation and causes the gill to appear as if rounded at the inner extremity. This is an important character, though not a very conspicuous one. The stem is fleshy and generally short and stout. Three species have been tried and approved, and are here described. Others reported as edible belong to our flora and await further trial.

Cap viscid when moist ................. T. transmutans.

Cap not viscid, reddisb-brown............. T. inbricatum.

Cap not viscid, reddish-violaceous ........... T. personatum.

\section{Tricholoma transwutans l'eck.}

Changher Tricholoma.

Plate 21. Figs. 1 to 5.

Pileus viscid when moist, tawny-red, becoming reddish-brown with age; lamella whitish or pale-yellowish, becoming dingy or reddish-spotted when old; stem whitish, generally becoming reddish-brown toward the base, stuffed or hollow, spores white, subglobose, .0002 in. broad.

The Changing tricholoma has the cap moist and sticky when young and fresh, or during wet cloudy weather. Its color at first is tawny or tawny-red, but with advancing age it generally becomes darker, assuming a cinnamon-red or reddish-brown hue, but sometimes retaining a paler hue on the margin than in the center. The flesh is white and emits a mealy or farinaceons odor, especially when cut. The taste also is farinaceous.

The gills are placed closely side by side and are notehed at the inner extremity where they are attiched to the stem. It lirst they are whitish or slightly tinged with yellow, but when old they are much darker and more or less spotted with reddishbrown. 
The stem is about as long as the diameter of the cap. It is generally paler than the cap, being whitish when young, but assuming darker hues with age, especially tomard the base. It is often stuffed with a softer substance or pith when young, but it soon becomes hollow.

Cap two to four inches broad, stem two to four inches long, about half an inch thick.

It grows in thin woods or open places in wet weather. It may be found from August to October. It is often found growing in tufts or clusters, but it is usually gregarious. It seems to prefer a sandy or light gravelly soil. It sometimes grows in company with the next species in grores of young spruce, balsam-fir and tamarack trees. Its edible qualities are rery similar to those of the next species, from which it is easily known when moist, by reason of the viscidity of its cap. It was first recorded as edible in the Forty-second Report.

\section{Tricholoma imbricatum $F r$. \\ Imiricaten 'Tricholosta. \\ Plate 21. Figs, 6 to 11.}

Pileus dry, innately squamulose, fibrillose toward the margin, brown or reddish-brown; lamella white, or yellowish. white, becomingreddish or spotted with reddish-brown; stem solid, whito and pulverulent at the top, colored like but generally paler than the pileus toward the base; spores elliptical, white, .00025 in. long.

The Imbricated tricholoma does not differ very greatly from the Changing tricholoma in size and color, but it can easily be distinguished from that species by thedry, not viscid, upper surface of its cap and by its solid stem. The cap is generally a little darker colored and its surface often presents a somewhat scaly appearance as if the epidermis had been torn into minute, irregular, scale like fragments. The color is a cinnamon brown or dark reddish-brown. The flesh is firm, white or whitish, and has a pleasant farinaceous odor and taste when fresh.

The gills have rery nearly the same color and character as those of the Changing tricholoma.

The stem also is similar to the stem of that species, but it has no central cavity. Sometimes when old it becomes hollow by the mining of insects. 
Cap two to four inches broad, stem two to three inches long, one-third to two-thirds of an inch thick.

This species grows under or near coniferous trees, such as pine, spruce, hemlock and balsam-fir. It appears in September and October. Like the preceding species it sometimes grows in clusters. It is often associated with Tricholoma vaccinum, a species very similar to it in size and general appearance, but which differs in three particulars. The margin in the young plant is covered with a soft downy or cottony coat, the stem is hollow and the taste is bitter or unpleasant. Nevertheless some writers class it among the edible species. Gillet says it is edible, but not of a very delicate flavor. So much do the two species resemble each other that so good a mycologist as Persoon seems to have confused them under the common name Agaricus rufus. A mistake of this kind by any one using the Imbricted tricholoma for food would not be serious, since this closely related plant has no dangerous properties.

\section{Tricholoma personatum $F$. \\ Masked Tricholoma. \\ Plate 22.}

Pileus moist, glabrous, variable in color; lamellæo crowded, rounded behind, free or nearly so, separable from the pileus, violaceous becoming sordid-whitish or fuscous; stem short, solid, fibrillose, whitish, commonly tinged with lilac or pale riolet; spores elliptical, sordid-white, .0003 to .00035 inch long.

The Masked tricholoma is worthy of a place among the escu. lent species of the first class. When young the cap is very convex and firm, but when mature it is nearly flat and the tlesh is more soft. It is very smooth and usually quite regular in shape when young, but in older plants the margin sometimes becomes irregular or wary. In young plants the margin is rolled inwards and often whitened with downy or mealy particles or frosted with a slight bloom, but in old ones it is naked, and in wet weather it may even be curved upwards. The cap is apt to become water-soaked in wet weather, in which condition it has an uninviting appearance. It raries much in color, but generally it has a palo lilac hue, which is apt to change with age to a russety shade in the center. Occasionally the color of the cap is 
almost white or pale grayish. The flesh when dry is nearly white and has a pleasant taste.

The gills are closely placed and rounded at the end next the stem, to which they are but slightly attached, or from which they may be entirely free in some cases. They are generally more brightly colored in the young plant than in the mature one.

The stem is generally rather short and stout, its length being less than the diameter of the cap. It is solid, and externally adorned with fibrils and downy particles when young and fresh, but it soon becomes smooth. In color it is like the cap or paler than it. It is sometimes a little thicker at the base than at the top, and in one variety, which I have called rar. bulbosum, and which is represented by figures 7 and 8 , it is rery distinctly bulbous.

Cap two to fire inches broad, stem one to three inches long, one-half to one inch thick.

It grows in thin woods and in grassy open places. It does not often appear before September, but it may be found till freezing weather stops its growth. It generally grows singly or in groups, but occasionally it is found in clusters of several individuals.

Nearly all writers speak well of its edible qualities. Dr. Badham says that its taste is pleasant, and when not watersoaked it is a fine, firm fungus with a flavor like real. Letellier states that it can be eaten with pleasure and without the least risk. Others pronounce it edible, very good, highly esteemed, very savory. My own experience leads me to place it among the first-class mushrooms.

In England this species is sometimes called Blewits and in France, Blue stem, although the coior in our plant is more violet or lilac than blue. In Europe it is said to have been sometimes confused with Tricholoma nudum, a very closely related species, and also with Cortinarius violaceus, the Violet cortinarius, but such mistakes could result in no harm to the eater, for both these are edible and perfectly safe. So far as known, we have no hurtful species with which the Masked tricholoma would be likely to be confused. Its gills are somewhat separable from the hymenophore or flesh of the cap in the same manner as the gills of a Paxillus are, and for this reason the species has sometimes 
been referred to that genus, but mycologists generally place it in the genus Tricholoma. The spores, when dropped on white paper, hare not the clear white color shorn by those of most species of Tricholoma. The color is dingy-white or sordid-white.

\section{Clitocybe $F r$.}

The genus Clitocybe differs from Tricholoma in the character of the gills. They are attached to the stem by their inner extremity as in that genus, but they are not notched or excavated on the edge near the stem, and they are generally decurrent. Sereral of our species have been recorded as edible, but trial has been made by us of only a few of them. Those here described are tabulated below.

Cap thick-fleshed, with no reddish hues...... 1

Cap thin-fleshed, more or less reddish ........ 2

1 Cap grayish, gills close together.......... C. nebularis.

1 Cap brown or blackish-brown, gills wide apart. $\quad$ C. media.

2 Cap funnel shaped when mature.......... C. infundibuliformis.

2 Cap convex or nearly plane when mature... $\quad$ C. laccata.

\section{Clitocybe nebularis Batsch. \\ Clouded Clitocyib. \\ Plato 29. Figs. 8 to 13.}

Pileus fleshy, firm, at first conrex, becoming nearly flat; lamellw crowded, adnate or slightly decurrent, white or slightly tinged with yellow; stem firm, fibrillose, generally thickened at the base; spores elliptical, white, .0002 in. long.

Tho Clouded clitocybe is a rather large and firm mushroom with the eap at first convex, but when mature it becomes nearly flat or a little depressed. It is smooth and of a grayish or clouded-gray color, often becoming paler with age and sometimes evidently with a slight yellowish tint. The center of the cap is sometimes darker than the margin. In the American plant the color is generally paler than that of the European plant, as indicated by the published figures. 'The color of the flesh is white.

The gills are quite closely placed, and in the young plant are attached to the stem by the wholo width of the inner extremity, but as the cap expands they appear to run down upon the stem and terminate in a narrow point. They are white or slightly tingred with yellow. 
The stem is usually rather short and stout. It is thickest at the base and gradually tapers upward. It is firm and more or less adorned with longitudinal fibrils. It is generally paler than tho cap. Its center is somewhat softer in texture than the exterior parts.

Cap two to five inches broad, stem one and a half to three inches long, one-half to one inch thick.

The usual habitat is among fallen leaves in woods where it appears in September and October. I have never seen it in fields. It is a rare species with us. It sometimes grows in clusters.

Some of the French mycologists do not admit this among the edible species, but English writers speak highly of it. Cordier says it is bad; Richon and Rozé say that its flaror is scarcely agreeable, and that it should be placed among the suspected species. Quelet asserts that he has eaten it often and found it good, but that sometimes it is indigestible and nauseous. Roques classes it as edible. Bulliard says "it is very agreeable to the taste." According to Badham it requires very little cooking and the flesh is perhaps lighter of digestion than that of any other. Stevenson quotes it as edible and rery good, with a somewhat pungent taste and an odor of curd cheese. Cooke regards it as one of his favorite mushrooms, to which he gires special attention, and he thinks that no person, haring a practical knowledge of its qualities, would place it among the suspected species.

\section{Clitocybe media Peck. \\ Intwrameniate Clitooyie. \\ Plate 23. Figs. 1 to 7.}

Pileus at first convex, becoming flat or slightly depressed, dry, dark grayish-brown or smoky-brown, the margin often wavy or irregular, the flesh white, taste mild; lamella broad, subdistant, adnate or decurrent, whitish, the interspaces somewhat venose; stem not at all or but slightly thickened at the base, colored like or a little paler than the pileus; spores elliptical, white, .0003 in. long.

The Intermediate clitocybe is very similar to the Clouded clitocybe in size and shape. Indeed, it might easily be mistaken for a dark colored variety of that species, but when examined closely it will be seen that the gills are not so close together as in that 
species, the spaces between them being noticeably wider, and often marked with little ridges or cross veins. The stem is also more cylindrical, scarcely tapering at all from the base upwards. In this respect it differs also from the Club foot clitocybe, Clitocybe clavipes, a species scarcely differing from the Intermediate clitocybe in color, although it has a more soft and spongy flesh and its cap is more narrow and more gradually tapering downward into the stem. It therefore appears somewhat like an inverted cone, while the stem may be compared to a long and narrow cone whose apex is united with the apex of the inverted one formed by the cap.

The Intermediate clitocybe is very scarce, and has been found in cool deep woods only, growing among mosses that thickly carpeted the ground. It occurs in September. Its flesh is well flavored and it is a mushroom well worthy a place among the most desirable species. It is a matter of regret that it is not more abundant. It was first published as edible in the Forty. second Report of the State Museum, its edible qualities having been tested by the writer.

\section{Clitocybe infundibuliformis Schaef: \\ Funnel-Form Chitootbe. \\ Plate 24. Figs. 1 to 6.}

Pileus at first convex and umbonate, becoming infundibuliform: dry, flaccid, reddish or pale tan color, fading with age; lamellx decurrent, white; stem generally tapering upward from the base: colored like or paler than the pileus; spores somerwhat elliptical, white, .0002 to .00025 in. long.

The Funnel-form clitocybe is a neat and rather pretty species, easily recognized by the funnel-like shape of the mature cap and its pale red color. When young the cap is slightly convex and of ten adorned with a very small prominence or umbo in the center. If observed closely it will be seen to be coated with a slight down or silkiness, especially on the margin. But as the cap expands it becomes depressed in the center, and in wet weather it resembles somewhat a large wine glass in shape. The color is apt to fade and sometimes the margin of the cap becomes irregular or wavy. Occasionally specimens occur in which the cap is almost white. The flesh is thin and white. 
The gills also are thin and white or whitish and rather closely placed. They run down on the stem in the mature plant, ending in a narrow point.

The stem is quite smooth and generally tapers upward from the base. It is sometimes white, but more often is colored like the cap. Usually a soft white down or felt is noticeable at its base. This is its mycelium which spreads in the soil or among the fallen leaves in which it grows.

The cap is two to three inches across, the stem is two to three inches long and one-fourth to nearly one-half an inch thick in the largest specimens.

It is not uncommon in woods in summer and autumn. Like many other species it is more abundant in wet weather. It delights especially to grow among fallen leaves in mixed woods, and though generally single or scattered in its mode of growth it sometimes forms clusters, in which case the cap is apt to be more or less irregular.

Although small in size and thin in flesh it affords a very delicate and delicious food.

When once known it is easily recognized, and I do not know of any hurtful mushroom in our flora with which it is likely to be confused.

\section{Clitocybe laccata Scop. \\ Lajoate Clitocybe. Waxi Clitocybe. \\ Plate 25.}

Pileus thin, convex or nearly plane, sometimes umbilicate, hygrophanous, glabrous or minutely scurfy-squamulose; lamellix broad, distant, adnate or slightly decurrent, more or less tinged with flesh color; stem slender, equal, fibrous, stuffed, colored like the pileus; spores globose, rough, .0003 to .0004 inch broad.

The Laccate clitocybe is a small but very common species which has a very wide range and is sometimes very abundant. It is also very variable, but easily recognizable when its peculiar characters are understood. It is thin in flesh, not highly flavored and apt to be tough, but because it has been classed among the edible species of Europe and because of its abundance and availability it is here admitted.

The cap is convex or nearly plane, even or umbilicate, smooth on with a slight scurfy roughness, When moist it has a watery 
appearance, and as this moisture dries the color changes more or less. In the moist state the color is some shade of palo red, butf red or flesh red, but when dry it fades to a grayish or pale ochraceous hue.

The gills are broad, rather wide apart and attached to the stem by their entire width. Sometimes they are slightly decurrent and occasionally emarginate, contrary to the generic character. They have a peculiar pale fleshy red huo which is more persistent than the color of the cap, and which is ne of the best characters for the recognition of thespecies. When mature, they are apt to be dusted by the whito spores.

The stem is rather long and slender, having a fibrous appearance and being either straight or flexuous. It is stuffed or almost hollow, rather tough and colored like the cap).

Tho cap varies from half an inch to two inches in horizontal diameter, and the stem from one to three inches in length and one to three lines in thickness.

There are severd well marlied varieties that hare received names. One of the prettiest is the Amethyst rariety, Variety amethystina, Figs. 23 to 27 , in which the moist cap is much darker colored than in the ordinary form, and when dry it is of a grayish hue, but the gills have a beautiful deep violaceous color which is quite persistent. The spores are rather large and the lamella more decurrent than usual. It may bo a good species.

In Variety pallidifotia, tho pale gilled variety, the gills are much paler than usual, being but slightly tinged with the ordinary flesh color.

In Variety striatula, the striatulate variety, tho plants are small, the cap is smooth, and so thin that shadory lines or striations are seen on it radiating from near the center to the margin. This variety usually grows in rery damp or wet places. Its spores are rather large, which may inclicate a good species.

Tho Laceate mushroom may bo found from the beginning to the ead of the season, if the weather is not too dry. It is not particular as to its place of growth, but occurs in woods, groves, swamps or opon fields, growing on naked ground or among grass, mosses or fillen leares. It is especially fond of pine woods or groves whero tho soil is liept shaded and moist.

Becauso of its departuro from tho greneric character in its peculiar gills and spores it has been placed by somo writers in a distinct 
genus under the name Laccaria laccata. It is closely related to Clitocybe ochropurpurea B. \& C., a much larger species with a paler cap and brighter gills, and a short thick stem and often an irregular deformed derelopment. This also should be associated with it generically under the name Laccaria ochropurpurea, if that genus is sustained.

\section{Pleurotus Fr.}

The genus Pleurotus scarcely differs from Tricholoma and Clitocybe except in the relative prosition of the stem and the cap. In these genera the cap is supported by a stem which is attached to it centrally. In Pleurotus the stem is attached to the cap at some point to one side of the center. Sometimes this point is on the very margin of the cap, and in a few species the stem is scarcely developed at all. Some of the species have the gills rounded or notched at the inner extremity as in the genus Tricholoma, and some have them decurrent on the stem as in Clitocybe. $\Lambda$ distinctive character which is worthy of notice in this genus is found in the habitat. All the species, with which we have to do, grow on dead wood, while those of the two preceding genera, so far as here given, grow on the ground. Generally their flesh is more tough than in terrestrial species. Sometimes they grow from dead spots or dead branches of living trees, and are often out of reach, being far up from the ground.

Stem present, distinct................... 1

Stem wanting or indistinct................. P. ostreatus.

1 Spores white........................ P. ulmarius.

1 Spores faintly lilac-tinted................. P. sapidus.

Pleurotus ulmarius Bull.

Elai Pleliotes.

Plate 26. Figs. 1 to 4.

Pileus convex or nearly flat, firm, glabrous, white or centrally tinted with reddish-yellow or brownish-yellow, flesh white; lamellac rather broad, rounded or notched at the inner extremity, adnexed, white or creamy white; stem firm, eccentric, generally curved, white or whitish; spores globose, white, .0002 to .00025 in. broad.

The Elm pleurotus, or elm tree mushroom, is a conspicuous object, growing, as it generally does, from doad places in or on 
the stumps of cut branches of standing elms. By its large size and white color it easily attracts attention. Its cap is broadly convex or nearly flat, quite smooth and usually white or whitish. Sometimes it is centrally tinged with a rusty or dull yellowish hue, and occasionally adorned with roundish spots as shown in figure 2. I have never seen the American plant as highly colored as some of the figures of the European plant. Sometimes the epidermis will be found cracked in small areas giving to the cap a scaly or tessellated appearance, and occasionally it cracks longitudinally. The flesh is firm and white.

The gills are quite broad and not very closely placed side by side. They are notched at the inner extremity as in species of Tricholoma. They are white, or when old, tinged with yellow.

The stem is firm and solid and united to the cap a little to one side of the center. It is generally more or less curved. This is especially the case when it grows from the side of the trunk of the tree. It is commonly smooth, but sometimes a little downy or hairy at the base. In color it is white or whitish.

Cap three to fire inches broad, stem two to four inches long, one-half to three-fourths of an inch thick.

It appears from September to November. It is not uncommon to see this mushroom late in autumn growing on the elms that have been planted as shade trees along the streets of our cities and in our public parls. It grows especially on those that have been severely trimmed or had their tops cut away. Its time of appearance is so late in the season that it is not often infested by insects. It therefore persists a long time and will keep two or three days without harm. Its flesh is not as tender as that of many of the mustrooms that grow on the ground, but it has an agrecable flaror and is quite harmless. Mlost-tree-inhabiting mushrooms grow more slowly and are, therefore, more tough and more slow to decay than those growing on the ground. They aro also less easily collected since they often grow high up on standing trees. In consequence of their persistent character they are easily dried and preserved for winter use.

The Elm pleurotus sometimes grows on other than elm trees, as the maplo and poplar. Occasionally when growing from the cut surface of an upright stump, or from the upper side of a branch, its stem is straight and attached centrally to the cap. Such a form has received the name Variety verticalis. $\Lambda$ form 
is said to grow in Europe in which the whole stem is downy or hairy, but I have not found it in our State. According to Vittadini the Elm pleurotus is a fungus of first quality and very desirable. Letellier commends it as an article of food because of its large size, and Dr. Cooke mentions one specimen which was su large that it made a good meal for three or four persons. Quelet says that it is sapid, but should be eaten while young. When dried specimens are soaked several hours in water they resume their original size and are nearly as good as if fresh.

\section{Pleurotus sapidus k̈alchb. \\ Sapid Pleevrotus. \\ Plate 27.}

Pileus convex or depressed, glabrous, often irregular, variable in color, flesh white; lamella subdistant, decurrent, whitish; stems commonly tufted, growing from a common base, eccentric or lateral, glabrous, white or whitish; spores oblong, pale lilac, .00035 to $.00045 \mathrm{in}$. long.

The Sapid pleurotus generally grows in tufts or crowded clusters, whose stems are more or less united at the base, and whose caps crowd and overlap each other. The caps are smooth and firm and in wet weather are somewhat moist. They are convex on the upper surface or centrally depressed, and owing to their crowded mode of growth are often very irregular in shape. They vary greatly in color, being white, yellowish, ashy gray, dull lilac or even brownish. The llesh, howerer, is white.

The gills are rather broad and somewhat wide apart. They run down on the stem and there often branch and connect with each other. They are whitish or yellowish and sometimes present a ragged or torn appesrance.

The stems are generally short and two or more usually grow from a common base. They are commonly white and smooth, solid and firm, and attached to the cap laterally or a little to one side of tho center, though specimens occasionally occur in which the stem is quite central.

The peculiar character which distinguishes this species, and about the only one that is available for separating it in all cases from the next, is the lilac tint of the spores. When these are thrown down on black or brown paper they have a sordid, whitish appearance, but if caught on white paper the color of the mass 
is a very pale dull lilac as represented by figure 9. It has seemed to me that they are whitish, even on white paper, when first thrown down, but after a short exposure or after a greater accumulation the lilac tint appears. Notwithstanding this peculiarity in the color of its spores the species is classed among the white-spored mushrooms, and it is perhaps a question whether it is, after all, anything more than a variety of the next species.

Cap two to five inches broad, stem one to two inches long, onefourth to two-thirds of an inch thick.

The Sapid pleurotus grows in woods and open places from June to Noveraber. It is quite common and more abundant in wet weather. It inbabits decaying wood and may be found about old stumps, prostrate trunlis of trees or even on dead or dying trees while yet standing. Sometimes it appears to grow from the ground, but a careful investigation would show that it starts from some decaying root or some buried piece of wood. In Europe it is said to grow on olm and oak, but in our State it inhabits other trees also, such as beech, birch, maple and horse chestnut. I have eaten it both fried and stewed and consider it about the same as the Oyster mushroom in edible qualities. In Hungary, according to Dr. Kalchbrenner, it is eagerly sought for food in the woods, and is also cultivated on pieces of elm trunks in gardens.

\section{Pleurotus ostreatus Fr.}

\section{Orgter Pleurotus. Orster M Mrhroom. \\ Plate 20. Figs. 5 to 9.}

Pileus convex, soft, imbricated, glabrous, moist, whitish, cinereous or brownish, flesh white; lamellw broad, decurrent, anastomosing at the base, white or whitish; stem short, firm, mostly lateral and indistinct or absent; spores oblong, white, .0003 to $.000 \pm$ in. long.

The Oyster mushroom or Oyster fungus, so named because of its shape probably, rather than because of its llavor, is very similar to the Sapid mushroom. According to the descriptions of the European plant it is quite variable in color, but with us the prevailing colors are white or ashy-gray, changing to yellowish in the old or dried state. 'The stem when present is grenerally shorter than in the Sapid pleurotus and more of ten lateral. It is sometimes hairy at the biso and somotimes wanting entirely. But the caps are 
slustered and overlapped very much as in that species, and the gills are the same in both. For table purposes there is little need of keeping the two distinct. Both are much more liable to be infested by insects than the Elm pleurotus. Both grow on decaying wood and at the same season and under similar conditions. The Oyster mushroom is apparently much less frequent in our State than the Sapid mushroom. It has long been classed among the esculent species, but in consequence of the toughness of its flesh it does not rank as a mushroom of first quality. Mliss Banning states that she bas eaten it both raw and cooked, but that she failed to detect any resemblance between its flavor and that of the oyster. Dr. Cooke says that it is a fleshy fungus, and when slowly and carefully cooked it is a pleasant and digestible one, but that it may be spoiled by bad treatment. French writers speak well of it and agree that it is both safe and excellent, but some recommend it only while young and tender. No charge of being deleterious is brought against it.

The remaining white-spored genera here represented differ from all the preceding either in the character of the gills or of the flesh.

\section{Hygrophorus Fir.}

In the genus Hygrophorus the gills of the mature plant have a soft waxy texture which distinguishes them from all others. They are not easily separable into the tivo membranes which form their two surfaces, as in the preceding genera. As in Pleurotus, the gills of some of the species are rounded or notched at the end next the stem, but of others they are decurrent on it. Those with decurrent gills bear considerable external resemblance to the species of Clitocybe, but the gills are generally thicker and much further apart than in that genus. No species of Hygrophorus is known to be dangerous, though two or three have been classed as suspected.

\section{Hygrophorus pratensis Fr.}

Meadow Hrgrophorus. Pasture Urarophord8.

Plate 28. Figs. 11 to 17.

Pileus compact, convex turbinate or nearly flat, glabrous, the margin thin; lamellæ thick, distant, decurrent, whitish or yellowish, the interspaces veiny; stem short, glabrous, white or whitish, 
sometimes yellowish; spores broadly elliptical, whitish, .0002t to $00025 \mathrm{in}$. long.

The Meadow hygrophorus, also called Pasture hygrophorus and Buff-caps, is a rather small but stout-appearing mushroom, which is quite variable in the color of its cap. This is commonly buff or yellowish, more or less tinged with red or tawny hues. Sometimes it is almost white. When young, the cap is nearly hemispherical or strongly convex, but with adrancing age the thick fleshy center becomes more prominent. In full maturity the thin margin is apt to be extended horizontally so that the surface of the cap is nearly flat and its shape resembles an inrerted cone whose sides are fluted by the widely separated gills. The flesh is white or nearly so and has a mild taste.

The thick gills extend far down on the stem in the mature plant, and in the bottom of the spaces between them cross veins may bo seen connecting them together.

The stem is mostly white, or if tinged at all with the color of the cap, it is paler than it. Sometimes it tapers downward, becoming more narrow at the base than in the upper part. Its sur. face is smooth.

Cap one to two inches broad, stem one to two inches long, one-fourth to one-half an inch thick.

This species grows in old pastures and clearings or in thin woods. It is often found in old abandoned fields partly orergrown with brakes and bushes. It may be found from July to September.

It has, for many years and by nearly all writers on this subject, been classed with the edible species, and Dr. Cooke pronounces it to be thoroughly wholesome and of delicate flavor.

\section{Hygrophorus miniatus $F \%$ \\ VETMILTON II YrROHYHORUS. \\ Plate 28. Figs. 1 to 10.}

Pileus thin, fragile, at first convex, becoming nearly plane, glabrous or minutely squamulose, often umbilicate, generally red; lamellw distant, adnate, yellow, often tinged with red; stem slender, glabrous, colored like the pileus; spores elliptical, white, .0003 in. long. 
The Vermilion hygrophorus is a very highly colored, beautiful species. It is small, but in some localities it is so abundant that no difficulty need be encountered in procuring a quantity of it sufficient for a meal for a large family. The cap is thin and fragile, and it must be handled with care or it will be brolien. In the young plant it is convex, but it expands with age until it is flat or eren centrally depressed. Its surface is sometimes smooth and even shining, again it is roughened as if coated with minute scurfy scales. Frequently there is a little central depres. sion or umbilicus in it. When young and moist the margin often shows slight striations, but in the dry or mature plant these are not seen. The margin is often irregular or wary, and in very wet weather it may become curved upwards so that the cap becomes concave. The color is usually a bright red or vermilion, but sometimes it fades to paler or orange shades, and there is a variety in which the whole plant is yellow. This I have called variety lutescens and have represented it by figures 9 and 10. The bright color of this plant is apt to disappear in drying.

The gills are commonly yellow, but sometimes they are more or less tinged with the red color of the cap. They are not so wide apart as in the Meadow hygrophorus. They are generally attached to the stem by the entiro width of the inner extremity, but specimens occur in which they are plainly notehed at the inner end, and others are found in which they are slightly decurrent.

The stem is rather slender. In young plants it is solid, but in older ones it becomes wholly or partly hollow. It is colored like or sometimes paler than the cap.

Cap one-half to two inches broad, stem one to two inches long, one to tro lines thick.

The Vermilion hygrophorus grows in woods, swamps and old fields in soil either wet or dry, among mosses or fallen leaves or on naked earth. It is sometimes found in great profusion in recent clearings over which fire has run. In such places it commonly attains a larger size than in dense woods, the cap attaining a diameter of even three inches. It is evidently fond of moisture and is more abundant in wet weather than in dry. It will grow even in the wet Sphagnum of peat bogs, and yet it is also found on the dry knolls and hillocks of the Adirondack 
region, growing freely under the shade of the brakes (Pteris aquilina) that cover them. It thus shows a great adaptability to varying conditions. It grows either singly, in groups or in clusters, and may bo found from June to September. It is especially abundant in the Adirondack region.

Having experimented with this species twenty years ago I was agreeably surprised to find it scarcely surpassed by any in tenderness of substanco and agreeableness of flaror. It was first recorded as an edible species in the Trenty-sixth Report of the State Museum.

A common species that closely resembles it is the Chantarelle hygrophorus, Irygrophorus Cantharellus. This is a smaller and more graceful plant, having a long slender stem and gills running very distinctly down on it. The colors of the two plants are the same, and they might easily be confused unless the character of the gills is noticed.

\section{Lactarius $F\}$.}

In the genus Lactarius the gills exude a milky or colored juice where cut or broken. This character alone is sufficient to dis. tinguish this genus from all others, but thore are other features which are quite characteristic. The texture is such that while the flesh seems firm and rigid it is nevertheless rery brittle and easily broken. The fracture is quito even and not ragged or $t$ rn as in more fibrous or filamentous substances. The species are mostly stout and fleshy in appearance and resemble in outline those of the genus Clitocybe. In the mature plant the cap is generally somewhat funnel-shape or like a broad inverted cone. 'The gills are more or less decurrent and the stem is mostly stout and short. Some of the species have the cap adorned with circular zones or bands more highly colored than the adjacent parts. 'This feature is rarely seen in any other genus. The taste of the juice and flesh in many species is very acrid or hot and burning, liko that of cayenne pepper. Unless this can bo destroyed by cooking or drying such species must be considered wholly unlit for food. There is much uniformity in the spores of all the species. 'They are globose or nearly so and roughened by minute points or protuberances. 'Their color may bo whito or yollowish, according to the species. 


\section{Lactarius deliciosus $F r$.}

Deliciods Laotarius.

Plate 29.

Pileus at first convex and often slightly umbilicate, becoming nearly plane or centrally depressed, sometimes almost funnelshaped, glabrous. yellowish-orange or grayish-orange varied with brighter mottled zones; lamellæ orange colored; stem glabrous, often marked with a few orange-colored spots, colored like or paler than the pileus; juice orange-colored; spores globose, yellowish, .0003 to .0004 in. broad.

The Delicious lactarius is well marked by its peculiar colors and is easily distinguished from all our other species of Lactarius by its orange-colored juice. The cap is conrex when young, but in the mature plant it sometimes becomes centrally depressed or even shaped like a funnel. It is smooth, and when fresi and moist its surface is slightly viscid. Its color is some shade of orange enlivened by mottled circles or zones of deeper hue. These zones often appear as if composed of numerous confluent spots. They are less distinct in old plants, in which also the ground color fades and becomes tinged with greenish hues, as shown in figure 4. Such plants have an unattractive appearance and should not be used for food. The flesh is whitish, but tinged with orange, especially along the line of attachment of the gills. There is often a slightly acrid taste to it when fresh.

The gills are very similar to the cap in color. The orangecolored milk exudes from these in drops if they are cut or broken. This milk or juice pervades the whole plant and may exude from wounds in any part. Wounds and bruises slowly assume a dull greenish hue.

The stem is colored like or a little paler than the cap and is often adorned with a few bright orange spots. It is generally quite short when growing on naked ground, but longer if growing among mosses. In some cases it is narrowed at the base, in others not. It is generally hollow in mature plarits.

Cap two to five inches broad, stem one to four inches long, onethird to two-thirds of an inch thick.

Common in woods, groves and damp, mossy places. It is especially fond of pine woods and mossy swamps, though not by any means limited to these. It may sometimes be found in 
swamps when dry weather prevents its growth elsewhere. It appears from July to October.

The following are some of the many quotations that might be made concerning the edible qualities of this mushroom. It is one of the best mushrooms with which I am acquainted and fully deserves its name and the high estimation in which it is held. Its flesh is firm, juicy, sapid and nutriticus. Badham. It is the most delicate and the safest mushroom known. Vittadini. It is a species highly esteemed and generally liked. It is ve!y good when properly cooked. It is also good preserved in vinegar. Richon and Rozé. It is certainly very good when cooked with care. Quelet. It is most excellent. Berkeley. Fried with butter and salt it has a taste like lamb. Seynes. It is edible but it is not as good as its name seems to indicate. Gillet. Served at the annual Woolhope dinners, it has always given satisfaction. Cooke. It is the most delicious mushroom known. Sinith. My own experience with it leads me to consider it very good but scarcely equal to the best. Doubtless differences of opinion concerning it may be due in part to different methods of cooking. It is said to require delicate cooking, for too long or too rapid cooking will make it tough. One of the best methods is to bake gently three-fourths of an hour in a close corered dish, having seasoned it with butter, pepper and salt. I consider it one of our most valuable mushrooms, becauso of its common occurrence and goodly size, and because of the almost total impossibility of mistaking any deleterious species for it if regard be had to the color of its juice. From this it is sometimes called the Orange milk mushroom.

Lactarius volemus Fr.

OrangE-JBROWN LiatakiUg.

Plate 30

Pileus convex or nearly plane, sometimes becoming centrally depressed or almost funnel-form, glabrous, dry, golden-tawny or brownish-orange, sometimes darker in the center; lamella crowded, adnate or subdecurrent, white or tinged with yellow; stem colored liko or a little paler than the pileus, glabrous; juice white, abundant; spores globose, white, .00035 to .00045 in. broad.

The Orange-brown lactarius is a clean, firm and attractive species. It varies but little in color and is, therefore, easily recog. 
nized. The cap is at first convex and, as in nearly all species of Lactarius, with advancing age it expands and becomes nearly flat or is somerwat depressed in the center and slightly funnel form. It is very smooth and generally quite regular. Sometimes it has a slight umbo or protuberance in the center as shown in figure 2. In the mature plant the epidermis sometimes cracks into small angular patches or areas. In the descriptions of the European plant this is given as one of the distinguishing characters of the species, but it is by no means constant in the American plant. Indeed, it is more often absent than present. The color of the cap is a peculiar mixture of red, brown and yellow, somewhat difficult to describo. It has been called reddishtawny, golden-tamny, brownish-orange and orange-brown. It varies somewhat in the depth of coloring, some being a shade darker or a shade paler than others, but the essential color is quite constant. In variety submgosus, represented in figure 6, the margin of the cap is roughened with wrinkles which form irregular reticulations. In this variety the color is generally a little darker than in the normal forms. The flesh is white, sometimes tinged with yeilow.

The gills are closely placed side by side and are attached to the stem by the whole width of their inner extremity, or in mature funnel-form caps they run down on the stem somewhat. They are white or yellowish. Where cut or broken a white juice or milk exudes in drops, and wounds or bruises quickly assume a brownish hue.

The stem is colored like the cap, but generally it is a little paler. It is quite tirm and smooth and generally solid. It varies in length but is not often longer than the diameter of the cap.

Cap two to five inches broad, stem one to four inches long, one-third to three-fourths of an inch thick.

It grows in thin woods and open places. It is especially found in woods and groves of chestnut and oak. It is a common species and occurs from July to September. It is most abundant in warm showery weather. Usually many indiriduals will be found growing in company or in groups, so that it is not difficult to obtain a generous supply for the table. It is remarkably free from the attacks of insects, which is a point in its favor as an esculent. Soruetimes in drying it emits an unpleasant odor, which is per- 
haps an indication that the specimens should not bo liept too long before cooking. Many writers allirm that this fungus is guite as grood raw as it is cooked, but to me it often has a slightly acrid or astringent flavor in tho raw state. All acknowledge it to be eliblo.

Cordier says it is excellent and among the most agreeable ediblo mushrooms, and that in some countries it is eaten raw as well as cooked. Paulet declares it to be fine and delicate and that it is eaten with delight. Quelet asserts that it is better raw than cooked and that its sweet milk affords an agreeable drink for tho botanist in the warm days of summer. Stevenson gives it as ediblo and delicious. My own experienco with it would scarcely lead mo to class it as more than an ordinarily good mushroom. Perhaps it might bo improved by better cooking than I was ablo to givo to it. I havo not eaten it uncooked.

Thero aro tivo or three species somewhat similar to the Orangebrown mushroom in color, but nono of them are hurtful. Wo are sometimes cautioned against mistaking the Red lactarius, Lucturius rufus, for it. This is roported by liries as very pois. onous. I hatre found this on the high summits of the Catskills and in tho cold mossy swamps and woods of the Adirondack region, but nover in company with the Orange-brown lactarius. It is easily distinguished by its more red color, its smaller size, and especially by its excedingry acrid burning taste. No one who had tasted it in the raw state could bo induced to swallow the least particlo of it.

\section{Russuln Fir.}

Tho species of liusulu aro very similar to those of the genus Lactarius in size, shipe, structuro and texture. The spores also aro of the samo character. But this genus is at once separated by the absence of any milky or colored juice. The coloration is also peculiur in many of the species, bright or clear red and purplish hues provitiling. 'This charieter doubtless suggested the namo of tho genus. No species exhibits tho colored circular zones seen on the capls of so many species of lactarius. The tasto of the flesh is very similar in both, in somo species it being peppory or acrid, in others mild.

Tho following is tho only species which I hare tried, though soveral have beon recoriled as ediblo. 


\section{Russula virescens $\mathbf{H}$. \\ Grennisa Rubsura. \\ I'late 31.}

Pileus at first nearly globose, then expanded and convex or centrally depressed, firm, dry, adorned with small flocculont patches or warts, greenish, sometimes tinged with yellow; lamelloo moderately close, freo or nearly so, whito; stem short, firm, white; spores nearly globose, slightly roughened, white, .00024 to .0u03 in. broad.

The Greenish russula is quite distinct and easily recognized by its green or grayish-green and warty cap. In the young plant this is rounded or almost globutar, but it soon becomes convex and sometimes when maturo it may even bo centrully clepressed. Its surface is dry, not viscid as in some other greenish speeies, and it is broken up into small scales or wart liko patches. The margin in the typical form is oven, but specimens often oceur in which it is marlied with impressed lines or striations as in figures 3 and 4. The margin of tho expanded cap often becomes split. The flesh is white and has a mild taste.

The glis are white or whitish. They are narrow at tho inner extremity and barely reach tho stem. Generally some of them aro forked and often a few shorter ones interveno between tho long onos.

The stem is commonly shorter than tho diameter of the cap. It smooth, white and solid or somewhat softer and spongy in the conter.

Cap two to four inches broak, stem ono to two inches long, ono-half to three-iourths of an inch thick.

In grassy grounds, groves or thin woods. July and August.

A groen color in mushrooms is very raro, but in tho genus Russula thore are sovoral species that exhibit it or an approach to it. But theso all liek the wart-like adornments that charactorizo the Greenish russula, and thereforo noed not bo mistaken for it. The color in our plant is not a brioht greon, but one moro or less mingled with groy or yellowish. Sometimes tho contral part of the cap is morn highly colored than tho margin and sometimes it is paler, oxhibiting horo the yollowish tints.

Vittadini places this among the most safo and delicate species of Russula. Roquos speaks highly of i, and siys it can bo eaten 
with entire confidence. According to Cordier it is a deliciour mushroom with a pleasant taste and an agreeable odor. Richon and Roze say it has excellent qualities but it needs proper seasoning One of the most commendable of the cdible russulas, edible, but its flavor is improved by cooking, edible but in little demand, are other opinions recorded concerning it. My own experience indicates it as of second-rato quality, but entirely harmless.

Cantharellus Adans.

The genus Cantharellus is separated from all the preceding genera by the character of the lamellix. These have an obtuse or blunt edge, and are mostly forked or branched. They are generally narrow. In greneral appearance the species are not much unlike species of Clitocybe, fur the gills are usually decurrent, but their thick branching and anastomosing habit and blunt edge give a very distinct character to the hymenium.

\section{Cantharellus cibarius $F r$. \\ Cuantarelle. \\ Plute 32.}

Pileus fleshy, firm, convex, becoming expanded or slightly depressed, glabrous, yellow, the margin at first involute, then spreading and often wavy or irregular; lamellx narrow, thick, distant, decurrent, branoked or autstomosing, yellow ; stem firm, glabrous, solid, yellow; spores elliptical, pale yollowish, .0003 to $.000 t$ inch long.

The Chantarelle is beautiful in color if not in shape, and is most easily recognized. Its color is a uniform rich egreyellow, which is very constant. 'This extends to all parts of the plant except the inner flesh, which is white. The sufice of the cap is smooth, but owing to the lobing and wary character of the margin the shape is often irregular and unsymmetrical. The cap is generally convex or nearly flat above, but sometimes it is centrally depressed. It is gradually narrowed downwards to the stem, often presenting the generil outline of a broad inverted cone.

The gills are narrow, with a rounded or blunt edgo and with irregular branches which often connect with adjicent gills. In somo individuals they are moro branched than in others. 
The stem is variable in length. It is often curved or slightly crooked, and sometimes tapers downward. It is smooth and solid, and by some it is considered as good as the cap for food.

Cap one to three inches broad, stem one to two inches long, one-fourth to one-half an inch thick.

It grows in woods and open places. It is a common species, and may be found from June to September. A farorite habitat is in the deep shade of homlock or spruce trees, but it also grows freely in thin woods of deciduous trees in wet, showery weather. Ir commonly grows in groups but sometimes in curved lines, as if trying to form a "fairy-ring." The European plant is said to exhale an odor like that of ripe apricots, but I have not been able to detect any decided odor in the American plant. The taste of the inw plant is often a little pungent or acrid.

Tho Chantarelle has long been celebrated for its edible quali. ties. Fries says that it is justly enumerated among the most sapid fungi; Badham, that no fungus is more popular; Cocke, that it is alike esteemed in France, Germany, Austria and Italy, where it is eaten regularly and exposed in the markets for salo; Gillet, that it is an excullent plant whether used as food or as a condiment; Sterenson, that it is edible and delicious. According to Berkeley, it is occasionally served up at public dinners at the principal hotels in London on state occasions, when every effort is made to secure the rarest and most costly dainties. Miss Banuing aflirms that she has eaten it both raw and coolied and that by a confirned fungus eater it would bo pronounced most charming. My own trials of it would lead me to place it among the best and most important of our wild mushrooms.

The Orange chantarelle or False chantarelle, Cuntherellus aurantiacus, is the only species liable to be mistaken for the edible chantarelle. It may at once be recorgnized by the orange color of its gills, which are also thinner and more cluse and are regularly and repeatedly forked. Tho color of its cap is a palcr and more dingy yellow, varied with smoky-brown tints.

\section{Marasmius $F r$.}

The genus Marasmius differs from all the preceding genera by the tough texture of the small thin plants that compose it. Tho plant quickly withers or shrivels in dry weather and revives 
again under the influence of moisture. The gille are thin and hare an acute edge. They are rather tough and flexible like the cap. The spores are white.

\section{Marasmius Oreades Fr. \\ Fatritring MLiminoon. \\ Plate 14. Figs. 12 to 21.}

Pileus fleshy, tough, glabrous, convex or nearly plane, often somewhat umbonate, reddish or tawny-red, becoming paler with age or in drying; lamella broad, distant, rounded behind or tree, whitish or yellowish; stem slender, tough, solid, coated with a close dense villosity, whitish; spores nearly elliptical, white, .0003 to .00035 in. long.

The Fairy-ring mushroom has recired this name because of its tendency to grow in rings or circles. In France it is called False mousseron and in England, Scotch bonnets. It is also called Fairy-ring champignon. When young and moist its cap is reddish, tawny-red or pale yellowish-red, but it becomes paler with age or as the moisture disappears. When dry it is generally palo-yellow or butf, as shown in figures 16 and 17 . Sometimes it is slightly striated on the margin, especially when moist, as sbown in figure 12. Often it is prominent in the center as if broadly umbonate. This is seen in figures 13 and 14 . The fl ssh is rather thin, white and inclined to be tough.

The gills are rather broad and wide apart. They are rounded at the inner extremity and scarcely or but slightly attached to the stem. They are whitish or yellowish.

The stem is rather slender but solid and quite tough. It is covered with a fine close villosity or tomentum which can be scraped away, revealing the smooth surface of the stem bəaeath. Its color is whitish or pale-grayish

Cap one to two inches broad, stem one to two and a half inches long, scarcely one-Iourth of an inch thick.

Common in pastures, lawns and grassy places by roadsides. May to October; appearing in wet weatber or after heavy rains. It usually grows in groups, sometimes in arcs of circles or in complete circles o: oren in lines. It sometimes forms clusters.

It bas long beoa esteomed as edible, but nwing to its small size and sonowhat tcugh substanco it has not gained the goneral 
popularity it leserves. The following recorded opinions of it will not be without interest: It is rery good while young. When young it may be eaten in an omelet. It has a rery agree. able taste and odor and gives a delicious flavor to sauces, but it needs cooking a long time. There is little of it and it serres only as a condiment. It is edible and recommended especially as a condiment. It is delicious when broiled with butter. It may be pickled or dried for future use. It is very agreeable but in little demand because of its small size. It is a very delicious mushroom and the abundance in which it ererywhere grows makes it a very valuable one. Its tendency to toughness is easily overcome by proper cooking.

There are two or three mushrooms which are somerwat similar to the Fairy-ring mushroom in size and color, and which might by carelessness be mistaken for it. Ono of these, the Semiorbicular naucoria, Naucoria semiorbicularis, sometimes grows in company with it. It may be distinguished from it by the color of the gills, which in the mature plant are rusty brown. Its spores when caught on white paper havo a dark rusty or ferruginous color, and its stem is smooth.

The Oak-loving collybia, Collybia dryophila, also resembles it in the color of the cap and gills, but its gills are more narrow and very closely placed side by side, and the stem is very smooth and hollow. This usually grows in woods, but sometimes it occurs in open places and then might bo taken for the Fairy-ring mushroom through carelessness.

An esteemed correspondent gires the following method of cooking this mushroom:

Throw the clean caps into suflicient boiling water to make a nice grary when done, and cook them half an hour. Then rub together a small quantity of butter and flour and water, with salt and pepper, and add to the mushrooms, stirring for a moment. Pour on hot toast and serve in a hot dish.

Another method is to put the caps in water with butter and seasoning and let them simmer slowly ten or fifteen minutes. Then thicken with flour and serve alone, or if preferred pour over cooked meat.

As a condiment, chop in small pieces and add to cooking hash, stews, broths or meats just before time to serve. 
Polyporeæ.

Boleti, Polypori axd Liver Fungus.

In the family Polyporere the cap has no gills on the lower surface, but instead of them there are small tubes, holes or pores. The spores of the fungus are produced on the inner surface of these pores, and when mature, they are dropped or ejected from them into the open air. They may be caught in the same manner as the spores of agarics, but their color has not been ememployed in classification to the same extent that it has in that family. The edible species to be described belong to three genera, Boletus, Polyporus and Fistulina. The distinctive characters of these genera are indicated in the subjoined table.

Pores compacted together and forming a continuous

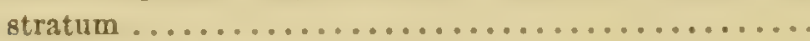

Pores each in a distinct tube .................. Fistulina.

1 Stratum of pores easily separable from the cap........ Boletus. 1 Stratum of pores not separable from the cap.......... Polyporus.

\section{Boletus Dill.}

The genus Boletus contains most of the edible species of this family. The substance of the cap is soft and fleshy and the cellular or porous stratum on the lower surface may be easily and smoothly removed by pressing it outwardly from the stefn toward the margin. This is the chief character by which to separate a boletus from a polyporus. Nearly all boleti grow on the ground and have the stem centrally attached to the cap. Unfortunately for mushroom eaters, many of them grow only in warm and wet or showery weather when insects are numerous, and therefore they are very liable to be infested by larve. Care must be taken to reject such plants. The stems also must be discarded, for they are too tough to be good. The tubes or pores are apt to form a disagreeable mucilaginous mass if retained, and it is well to remove them beforo cooking. Somo species have a viscid surface to the cap which causes dirt, sticks and leares to adhere tenaciously to it. The caps of such plants should be peeled before cooling.

Cap viscid when moist................... 1

Cap nol viscid ........................

1 Stem furnished with a collar.................. 2 
I Stem destitute of a collar

B. granulatus.

2 Stem dotted above the collar .................

2 Stem dotted both above and below the collar .....

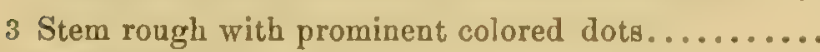

B. subluteus.

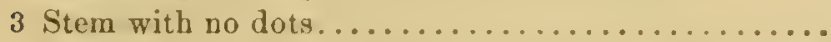

4 Margin of the cap adorned with adhering fragments of a membranous reil....................

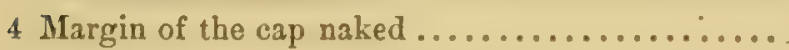

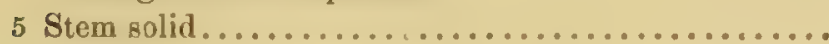

5 Stem hollow or cavernous ......................

B. rersipellis.

B. scaber.

B. edulis.

B. castaneus.

\section{Boletus luteus $I$.}

YeLLOW-BROWN BoLeTU.

Plate 3s. Figs. 7 to 12.

Pileus visciä or glutinous, dingy or brownish-yellow: somernat variegated with darizer lines, spots or streaks, flesi white, sometimes tinged with yollow; tubes minute, yellow, becoming darker or ochraceous-yellow with age; stem short, stout, annulato, yellowish and dotted above the membranous annulus; spores yellowish brown, .00025 to .0003 in. long.

The Yellow-brown boletus is ono of our rarest fungi. Its broadly convex or nearly flat cap is of a peculiar dingy color formed by a mixture of yellow and brown or reddish-brown, which is very abscurely varied by slightly deoper colored streaks or spots. When wet it is covered with a sticky gluten which is so tenacious that it can be peeled away with the cuticle. The flesh is white, but in mature plants it is sometimes tinged with yellow. The tubes are nearly plane in the young plant, that is, their mouths are in a plane surface. They are at first concealed by the white membranous reil which soon breaks from its attachment to the margin of the cap and shrinks to the stem, on which it forms a kind of collar. The young tubes are yellow, but they assume dingy ochraceous hues with age.

The stem is generally shorter than the horizontal diameter of the cap. It is yellowish above the collar and marked there with small brown dots. Below the collar it is generally more or less covered by a continuation of the veil, so that in very shortstemmed plants it appears as if sheathed by a wrapper as in the genus Amanita. 
Cap trio to fire inches broaä, stem one to two inches long, onc. half to three-fourths of an inch thick.

I have tound this species under pine trees only. It occurs in autumn.

European authors have written about its edible qualities as rollows: Edible and highly esteemed, ics flesh is very tender; 3 is excellent; it is good and extensively consumed in Germany.

\section{Boletus subluteus Peck.}

SMALL-YelLOWIBH BoLETUB,

Plate 33. Fir. 1. to 6.

Pileus viscid or glutinous when moist, often obscurely streaked or spotted, dingy-Fellowish or lerruginous-brown, flesh whitish or tinged with dull yellow; tubes plane and yellow in the young plant, becoming dingy-ochraceous witn rge, and sometimes conrex; stem slender, whitish or dingy-vellowisn, annulate, dotted both abore and below the annulus; spores oblong or subrusiform, .0003 to .0004 in. long.

The Small-yellowish boletus scarcely differs from the Yellow-brown boletus except in its smaller size and its more slender stem, which is dotted both above and below the collar. Its collar is less membranous in tha mature plant, for it collapses or shrinks into a thick, often discolored, band instead of persisting as a flexible membrane. It is quite probable that it has often been confused with the larger species, and so far as its edible character is concerned such confusion would not be serious for there is but little difference in their flaror. This species is much more frequent than the other. It may be found from August to October. It occurs only in pine regions or in places where pine trees once grew. It is especially fond of a light sandy soil shaded by a thin or scattered growth of pino trees.

I do not know of any dangerous species with which these two boleti are liable to be confused.

\section{Boletus granulatus $L$.}

Grandrated Boletes. Plate 84. Fing. 1 to 5.

Pileus viscid or glutinous when moist, variable in color, usually grayish-yellow or tawny, the flesh white tinged with yellow; 
tubes at first very pale-yellow, becoming dingy-ochraceous with age; stem short, thick, solid, dotted above, whitish or yellowish; spores oblong, rusty-ochraceous, .0003 to $.000 \pm$ in. long.

The Granulated boletus has the cap riscid or glutinous when moist. It varies much in color. It may be pinkish-gray, grayish-yellow, reddish or ferruginous-brown or tawny. It is sometimes obscurely spotted from the drying gluten. The flesh is rather thick and white except along the lower surface next the tubes where it is generally tinged with yellow. The tubes are at first pale-yellow or aimost white, but they assume the dingyochraceous hue which is common to many species in maturity. When examined closely, the mouths of the tubes are seen to be dotted with minute granules which give rise to the name of the species. These are at first in the form of drops of a thick juice, but with age they become dry and form brownish granules.

The stem is short, generally less than the horizontal diameter of the cap. It has no collar, but is dotted with small brown granules similar to those on the tube mouths. These granules are more numerous and distinct near the top of the stem. Sometimes they extend to the base, sometimes not.

Cap one and a half to four inches broad, stem one to two inches long, one-third to one-half an inch thick.

The Granulated boletus grows in pine woods and groves or under or near scattered pine trees. It may be found from July to October. It is one of our most common species in pine regions. It usually grows gregariously, many plants occurring in a small area. It sometimes grows in circles.

The absence of a collar on the stem at once distinguishes it from the preceding species.

The American boletus, Boletus Americamus, is often found growing with it and may be separated from it by the paleyellow color, both of the cap and the Hesh, and by its much more slender stem.

Nearly all authors agree in placing the Granulated boletus in the list of edible species. Dr. Cooke says that it has given him the greatest satisfaction and that he prefers it to the Edible boletus or, indeed, to any other which he has tried. This is a pretty strong recommendation, and is the more gratifying because this species is so abundant and so easily obtainable. 


\section{Boletus versipellis Fro \\ Oragae-OAP Boletus. \\ Plate a.: Figs, 6 to 10.}

Pileus convex, dry, smooth or at first very minutely tomentose, reddish or orange-red, the flesh white or grayish, the margin adorned with the inflexed remains of a membranous concolorous veil ; tubes small, depressed around the stem, whitish or grayishwhite, becoming darker or more dingy with age; stem rather long, firm, solid, roughened with small reddish or blackish prominent dots or scales, whitish; spores oblong-fusiform, brown, .00055 to .0007 in. long.

The Orange-cap boletus takes its common appellation from the color of the cap. This is quite constantly a dull yellowish-red, less brilliant than orange. The peculiar distinguishing feature of the species is found in the torn or somerwhat scalloped remains of the veil which adheres to the margin of the cap an 1 is of the same color as it. It is generally turned under the ruargin and adheres slightly to the tubes also. It is not difficult to imagine it to be an extension of the epidermis of the cap.

The tubes are rather long, and in the mature plant they often form a convex mass, those near the margin and those near the stem being shorter than the intervening ones. The color is at first whitish or grayish, but in the mature plant it is considerably darkor and not easily defined.

The stem is usually equal to or a littlo longer than the horizontal diameter of the cap. It is frequently a little narrowed at the top. Its color is similar to that of the young tubes, and it is adorned with numerous reddish or blackish prominent points, dots or scales. In some instances these are uniform in color, in others tho two linds of points are intermingled on the same stem.

Cap two to six inches broad, stem three to five inches long, onothird to three-fourths of an inch thick.

Wools and open places. I find this species especially in sandy soil of pine districts. It is single or scattered in its mode of growth and appears from Augrust to October. It is by no means as common as tho next species, to which, in my trials of it, it seemed inferior in esculent qualities. But differences in age or conditions of growth or in methods of cooking might make the difference in flavor. Dr. Cooke says it is equally as good as the noxt species. 
Boletus scaber Fr.

Rocgh-stemaed Boletus.

Plate 35.

Pileus glabrous or nearly so, commonly convex, the flesh white or whitish; tubes small, long, soon convex in the mass, depressed around the stem, at first whitish, becoming darker, dingy or brownish; stem firm, solid, often narrorved at the top, whitish or grayish, roughened with numerous small prominent, reddish or blackish dots or scales; spores oblong-fusiform, brown, .00055 to .0007 in. long.

The Rough-stemmed or Scabrous-stemmed boletus may well be called our most common and, in respect to color, our most variablo species. Its ca varies in color from white to almost black. It also varies somewhat in shape. It is gencrally convex or cusbionshaped, but scmetimes it is hemispherical or even broadly conical. Its surface is commonly smooth, but occasionally specimens are found in which it is slightly downy or even scaly. The llesh is white or whitish, and the margin in mature plants is often thick and blunt by reason of the lengthening of the tubes.

The tubes are long and mostly convex in the mass in the mature plants. They are much shortened around the stem, thus leaving a depression or cavity there. When young and fresh they are whitish, but they become darker and dingy or brownish with age. Bruises or wounds of the whitish tubes and flesh sometime: produce a slight change in color, it assuming pinkish or blackish hues.

The stem scarcely differs in any respect from the stem of the Orange-cap boletus, and its characters need not be repeated here.

Several varieties have been describer, most of which depenc. on the color of the cap.

Var. niveus has the cap white. Fig. 3. This is thought by some to be a distinct species.

Var. aurantiacus has the cap orange-red. Fig. 4. This differs from the Orange cap boletus only in the character of the margin of the cap.

Var. fuligineus has the cap fuliginous or cinereous-fuliginous. Fig. 5 .

Var. fuscus has the cap brown or dark-brown. Figs. 2, 6 and 7. 
Other variations in color are sometimes seen. Tho epidermis of the cap sometimes cracks into small angular areas or scales, which gire it a peculiar appearance. This form has been desigmated as Var. arcolatus, but neither this nor the varieties depending on color alone hare a rery substantial basis. They are probubly mere forms rather than true varieties.

Cap one to fire inches broad, stem two to fire inches long, onethird to two-thirds of an inch thick.

The Rough-stemmed boletus occurs ererywhere in woods, stramps and open places, and in sandy, gravelly, loamy or clayey soil. It may be found from June to Norember. It is easily recognized by its peculiar stem, no other species, except the Orange-cap boletus, having a stem like it. The dots are very different in character from those on the stems of the Granulated boletus and the Small-yellowish boletus. They are dry and fibrous, and not formed by the drying and hardening of a thick juice, as in those species.

Authors differ in their estimate of the edible qualities of this boletus. Some simply pronounce it edible; others say it is less agreeable than the Edible boletus, which is generally preferred to it. Gillet says that it can be eaten without the least fear, but that young plants should be selected for the table, old ones being generally more difficult of digestion. MY own experiments with it were highly gratifying, and lead me to consider it a first-class species for the table.

\section{Boletus edulis Bull.}

Enh:Le PMithes.

1'late 38. Figs. 8 to 12.

Pileus glabrous, compact, becoming soft with age, grayish-red, brownish-red or tawny-brown, often paler on the margin, the flesh white or tinged with yellow, reddish under the epidermis; tubes soon conrex, depressed around the stem, at first whitish, becoming rreenish-yellow; stem stout, equal or thickened at the base, reticulated in the upper part, sometimes wholly reticulated, solid, pale or brownish; spores oblong-fusiform, .0005 to .0006 in. long.

Tho Ediblo boletus is ono of our largo species, though it is by no means as common as desirable. When young the cap is firm and the tubes white, with their mouths very indistinct. With 
advancing age the cap becomes softer and more yielding to pressure and the tubes assume a greenish-yellow or greenish-ochra. ceous hue and their mouths are then distinct. In color the cap is quite variable, exhibiting a mixture of red, yellow and brown hues. It is most often tawny-brown or reddish-brown on the disk, with paler and yellowish hues on the margin. The flesh is tinged with red under the cuticle.

The tubes form a convex mass, being depressed around tho stem.

The stem is stout, solid and trm. It is adorned with a fine network of raised lines just below the tubes, and sometimes these reticulations extend to the base. It is most often somewhat swollen or thickened toward the base. Its color is generally paler than that of the cap, it being brownish or yellowish-brown or dingy white.

Cap four to six inches broad, stem two to six inches long, onehalf to one and a half inch thick.

The Edible koletus grows in groves, woods and their borders, and sometimes in open waste places. It occurs in warm, showery weather, during July and August. It holds a prominent place among edible boleti, just as the common mushroom does among edible agarics. It bas lorg been known as an edible species, and on this account its reputation has become widely spread. It has an agreeable, nutty flavor, even when raw, and it has secured favorable mention from nearly all writers on this subject. Badham recommends, especially, this and the Rough-stemmed boletus. Gillet says it is an excellent species, with an agreeable flavor, and that it is largely consumed in some parts of France. It is also cut in slices and dried for future use, and in this way is sold in the markets of Europe.

\section{Boletus castaneus Bull.}

Cinatnet lioletus.

Plate 88. Figs, 1 to 7.

Pilous convex, becoming nearly plane or depressed, dry, firm, at first minutely velvety, commonly reddish-tawny or cinnamon, flesh white, unchangeable; tubes short, small, at first white, becoming yellowish; stem firm, short, stuffed or hollow, colored 
like the pileus; spores oval or oroadly elliptical, pale-yellow, $.000 \pm$ to .0005 in. long.

The Chestnut boletus is unlike any other species here described, in having a hollow stem. Its cap is at first convex, but it becomes expanded with age and sometimes the margin curves upward, as shown in figure 4 . There is a minute relvety down on its surface, which is scarcely noticeable except to a close observer. The color is generally reddish-tawny or cinnamon. It is not always as dark as is indicated by the name.

The tubes are small and short. At first they are white, but they become yellowish as the plant matures.

The stem is short and not always straight. It is clothed and colored like the cap. Sometimes it tapers towards the top. When young it is soft and spongy in the center, but it becomes carernous or hollow when old, as shown in figure 6. Its pale yellow spores are also a peculiar feature.

Some species of this genus quickly assume bluish tints where the substance is bruised or broken. The rule is sometimes given to avoid all such as poisonous. And yet o ce correspondent, an enthusiastic mycophagist, informs me that he eats such species, and has done so repeatedly without harm. In ono instance however, which was brought to my notice, sickness and romiting followed the eating of the Sensitive boletus, Boletus sensibilis, a species which assumes a blue color in a remarkable manner whero bruised, cut or broken. Eren the pressure of the fingers in handling it causes it to assume blue spots where touched. All the family partaking of it were made sick, but all recovered.

\section{Polyporus Mich.}

In members of the genus Polyporus the stratum of pores is not smoothly or easily separable from the cap. Most of the species grow on dead or decaying wood and aro too tough for food. A few grow on the ground, but oven these are inclined to be tough. Vory few of the wood inlabiting species have a central stem and many have no stem at all. In some the texture is dry, hard, corky or woody, such as no ono would think of eating, and of those classed as edible, it is generally better to select only the very young plants for food. My personal experience with these has not extended beyond the single species here described. 


\section{Polyporus sulphureus Fr.}

Sulpherir Polvores.

Plate 37. Figs. 1 to 4.

Pileus broad, somerwat irregular and wary, growing in tufts and closely overlapping each other, uneven, reddish or orange color when young and fresh, fading with age, flesh white; tubes very small, short, sulphur yellow; spores elliptical, white, .0003 in. long.

The Sulphury polyporus is easily recognized by its clustered mode of growth and its attractive colors. The caps are often five or six inches broad and they closely overlap each other, sometimes forming tufts or clusters of considerable size. Generally the flesh is not more than balf an inch thick, white and easily broken. When young it is soft and juicy, and in warm, moist weather it sometimes exudes a yellowish milk or juice if cut or broken. In maturity it is dry and almost friable. The color of the young cap is yellowish-red or pale-orange, but the red or orange soon fades to yellow or becomes mingled with yellow. Its color is generally lost in drying. The margin of the growing cap is often beautifully yellow. It is more or less wary or irregular.

The tubes are minute and short. They are of a bright sulphuryellow color. which is more persistent than the red color of the cap.

There is no stem, but sometimes the cap is prolonged on one side into a stem-like base.

This species bas a wide rango and is found in all parts of our State. It grows in woods and in the open country. Its showy clusters are sometimes seen growing from dead spots ic the trunks of living standing trees. It is perfectly at home on the dead wood of nearly all kinds of trees. Eren fruit trees sometimes support it. It may appear at any time from Juno to September, but it delights in showery wet weather.

A variety sometimes occurs which might well be named rariety glomeratus. In it a multitude of small caps are so closely and intimately united that their individuality is lost in the large mass which they form. Irregular and unequal holes or cavities in the general surface of the mass afford opportunity for a partial de- 
ve.opment of tie pores or the imperfect caps. This rariety is said to be morc common in some of the western States than it is here.

In using the Sulphury polyporus for food, only the young and freshly grown caps were taken. These thinly sliced and fried in butter were much better than I had expected to find them. Mature specimens would probably bo tough, dry: disagreeable and indigestible.

\section{Fistulina Buis:}

In the genus Fistulina the tubes stand close to each other, but are separate or distinct from each other and do not form a continuous compact mass as in Boletus and Polyporus. They are at first very short and resemble minute warts or papillæ, but they become cylindrical with age. We have only the single species here described.

\section{Fistulina hepatica $F r_{\text {. }}$ \\ Liver Fistulina. \\ Plate 37. Figs. 5 to 9.}

Pileus fleshy, juicy, soft, dark-red, flesh red, variegated with brighter strealis; tubes small at first, yellowish or slightly tinged with pink, becoming dingy with age; spores elliptical, yellowish, .0002 to .00025 inch long.

The Liver fistulina has receired various popular names in countries where its edible qualities are generally known. Among these are Oak tongue, Chestnut tongue, Beef tongue and Beefsteak fungus. Its cap when young is roughened on the upper surface with minute papillæ, which, with its shape and red color, are suggestive of the name Beef tongue. These papilla disappear with age. In texture it is soft and juicy, but rather tough and somewhat fibrous. Its juice is reddish and the llesh is streaked with red. Its surface, when moist, is a little sticliy or clammy to the touch. Generally there is a short lateral stem, but occasionally specinens are found without any stem.

The tubes are on the lower surface of the cap and quite small. At first they are like small pimples or papilla, but they soon lengthen and become cylindrical. They are yellowish, more or less tinged with pink when young and fresh, but with ago thoy assume a dingy, ochraceous bue which is almost indelia able. 
The cap varies from two to six inches or more in breadth. It grows from old stumps of oak or chestnut in wet weather in July and August.

This Vegetable beefsteak or Beefsteak fungus has been highly commended by European writers. It has a slightly acid flaror, which is by no means disagreeable to some palates. Its toughness may be an objection with some, but it is not more tough than beefsteak. Some authors recommend only the young plant for food, but another says it is best when fully matured, the young fungus being somewhat bitter and astringent.

"It is good broiled with a steak and properly seasoned;" "if it is not beef itself, it is sauce for it;" "it is truly a vegretable beefsteak, for the taste resembles meat in a remarkable manner;" "no fungus yields a richer gravy, and, though rather tough when broiled, it is scarcely to be distinguished from broiled meat," are somo of the expressions concerning the edible qualitios of this fungus.

\section{Hydneæ.}

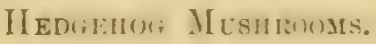

In the family IIydnere, the cap, when present, has neither gills nor pores on its lower surface, but instead of these there are numerous spine-like or awl-shaped teeth projecting downwards. On the surface of these teeth the spores are developed. There are several genera in the family, in which these teeth are variously modified in shape and size, but as there are no edible species among them, they do not concern us now. Our edible species belong to the single genus $\Pi y d n u m$.

\section{Hydnum $L$.}

The distinct awl-shaped teeth or spines on the lower surface of the cap, when the cap is present, characterize this genus. In one edible species the cap is replaced by numerous branches, on whose inferior surface the teeth are dereloped. There are many species which are merely thin, effused membranous expansions, on whose surface the teeth are formed, but these furnish no edible species.

Teeth on the lower surface of a cap............... repandum.

Teeth on the lower surface of Hattened branches.... H. coralloides. 


\section{Hydnum repandum $L$.}

SPREADING HYDNUMS.

Plate 38.

Pileus fleshy, fragile, convex or nearly plane, often irregular, nearly smooth, variable in color; spines pointed, whitish; stem stout, whitish or paler than the pileus, solid, often eccentric; spores globose, yellowish, .0003 in. broad.

The Spreading hydnum, or "hedge hog mushroom," figures 1 to 6 , is not rare with us. Its cap is somewhat variable in color. It may be a pale-buff or rusty-yellow or pale-red or sienna-red. It is not often well formed and regular. The margin is apt to be wary or lobed, and the stem attached to the cap a littlo to one side of the center. The substance is compact but easily broken. It is rather dry and whitish, but sometimes changes color slightly if cut or broken.

The spines or needles of the lower surface are about one-fourth of an inch long. They are whitish, often slightly tinted with yellow or pinkish.

The stem is mostly short, solid and stout, sometimes thickened at the base, sometimes at the top. It is commonly whitish, or at least paler than the cap.

Cap one to four inches broad, stem one to three inches long, one-half to three-fourths of an inch thick.

The Spreading hydnum grows in woods and in open places, either on naked soil or among grass or fallen leaves, either singly or in clusters. It appears from July to October.

The Reddish variety, Variety rufescens (Hydnum rufescens Pers.), figures 7 to 10 , is smaller, thinner and more regular, with the stem mostly central. Its color is more red than in the typical form, and by some it is considered a distinct species. It is more common in woods. Its edible qualities are similar to those of the typical form.

According to Badham, the Spreading hydnum is as good as oysters, which it somewhat resembles in taste. Stevenson says it is one of the most delicious fungi, but that it requires about four hours slow cooking. Berkeley also pronounces it a most excellent fungus, but one that requires a little caution in its preparation for the table. One method of cooking it consists in first slicing the caps and steeping trenty minutes in warm water; then placing in a stow pan with butter, salt, pepper and beef gravy and sim- 
mering slowly for an hour. Cooke suggests that, owing to its slight pungency of tlavor both raw and cooked. it may serve as a good substitute for mustard, and be placed with the meat in sand wiches. It may be dried and preserved for future use.

\section{Hydnum coralloides Scop. Coral-Like HTDNUM. \\ Plate 84. Figs, 11 to 13.}

Plant much branched, pure white, sometimes becoming yellowish with age; branches numerous, spreading, dense, angular or flattened, bearing the numerous crowded awl-shaped teeth along the lower side; spores globose, uninucleate, .0002 in. in diameter.

The Coral-like hydnum departs rery decidedly from the usual form of the species of this genus, and is so unlike the others that it might easily be thought to belong to another genus, and, indeed, some French authors have included it in a separate genus Dryodon. It is so white, and its branches and spines are so numerous and dense, that it has been compared to a cauliflower in its general appearance. Ochers have evidently thought it resembles some species of coral. The plant is generally from two to four inches high and nearly or quite as broad, but sometimes it attains much larger dimensions. 'The stem is very short, dividing into branches almost at the base. The larger branches aro more or less angular or compressed. The terminal ones are often curvel upwards and terminate in a crowded, somewhat spreading, mass of spines. Generally the spines are closely arranged along the lower side of the spreading branches and point downward toward the earth. 'They vary from one-sixth to one-third of an inch in length. They are easily broken. The pure white color of the whole plant, when young and fresh, and the unusual appearance of the branches, densely and stilly fringed by the pendulous spines, make this fungus a very noticeable and an attractive object. It is said that a desire to study fungi was first awakened in the illustrious Fries upon his beholding for the first timo this beautiful species growing in the woods.

It occurs on prostrate trunks of trees of rarious kinds, but with us it seems to prefer the beech. It is quite common in hilly and mountainous woods in rainy weather. It appears from August to October. 
In our botanical expeditions in the extensire wilderness of the Arlirondack region we.were often obliged to camp in the woods several nights in succession. On such oscasions this beautiful fungus sometimes contributed a luxurious dish to our ordinarily very simple and, sometimes, very limited bill of fare. In such cases it prored as good as it was beautiful.

It is scarely possible to mistake any deleterious fungus for this, and it also has the adrantage of generally being free from the attacks of insects and from dirt.

\section{Thelephoreæ.}

\section{Connecoria Jfeshroons.}

In the family Thelephorea the hymenium or spore-bearing surface is reduced to its utmost simplicity. It is a perfectly eren surface of the hymenophore, or one rendered slightly uneven by obscure wrinkles or inconspicuous papille or granules. But few species have a distinct stem and cap. Probably no edible species will be found outside the genus Craterellus.

\section{Craterellus Fr.}

In the genus Craterellus the spore bearing surface is even or slightly rugose or wrinkled. The caps are generally thin and sometimes long and narrowly obconical or funnel-shaped. A single representative species is here described.

\section{Craterellus cornucopioides P'ers.}

Cornucoria Craterelles.

1'late 24. Figs. ? to 10.

Pileus thin, flexible, tubiform, hollow to the base, blackishbrown, sometimes a little scaly; hymenium eren or somewhat rugose-wrinkled, cinereous; stem very short, almost wanting; spores elliptical, whitish, .0005 to .0007 in. long.

The Cornucopia craterellus, or "Horn of plenty," is more common than attractive. It is easily recognized by its elongated tubular or narrowly trumpet-shaped cap and its dingy-gray or sooty-brown hue. It takes its name from its peculiar shape. Its flesh is quite thin, a little tough, flexible and dry. The surface of the cap is smooth or but slightly roughened, with a fow obscure fibrous tufts or scales. The color varies from grayish to a dark smoky-brown or sooty hue. The 
margin is sometimes erect, sometimes widely spreading and decurved like the margin of a trumpet's mouth. It is often wavy, lobed, irregular, folded or overlapping, or split. The cavity of the cap extends to the very base.

The spore-bearing surface is commonly a little paler than the upper surface and varies from ashy gray to pinkish-brown or dark smoky-brown. It is generally a little uneven or rugosewrinkled. It extends nearly or quite to the ground, the stem being very short or almost wanting.

The cap is from two to four inches long and one to two and a half broad at the top. The plants grow gregariously or in tufts in woods and shaded places. It is found especially in old roads in woods on naked soil, or on shaded banks, but sometimes it grows among fallen leaves or mosses. It may be found from July to September.

Cordier and some other French writers class this fungus among the edible species, but say that it is not rery popular because of its thin flesh and dark color. Dr. Cooke admits that his first trial of this fungus was so satisfactory that he never missed an opportunity afterwards of gathering them for the table, and he says that a friend who learned of the edible qualities of this fungus from him now thinks nothing of walking six or eight miles to procure a dish of this craterellus.

\section{Clavarieæ.}

\section{Fatri Crobs.}

In this family no definite cap is dereloped, and no definite inferior fertile surface. The plants are of upright growth, either simple or branched, and the spores are developed on the upper or exterior surface of the plant or of its branches. The edible species are found in the single grenus Clavaria.

\section{Clavaria Vaill.}

In this genus the fleshy plant is either simple or branched. When simple it is commonly slightly thickened upward, assuming a shape similar to a club, a character which has suggested the generic name. In some of the branched species the branches are very numerous and crowded and the plants have an appearance strongly suggestive of a bush in miniature. The flesh in some species is very tender and fragile. 
In collecting them for eating care must be exercised to select only sound specimens, for insect larvæ usually enter the plant at or near the base, so that the branches may appear sound while the larra are at work below. Disappointment in the flavor will result from the use of the sound branches of such plants, for their flavor is spoiled by the presence of the larra in the base of the plant. No dangerous species are known in this genus, but some have a disagreeable flavor.

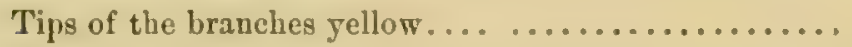

C. flava.

Tips of the branches red..................... C. botrytes.

Tips of the branches colored like the branches ........ C. cristata.

\section{Clavaria flava Schatit. \\ Pale-yfliow Clavaria. \\ Plate 39. Figs. 1 to 4.}

Stem short, thick, white, much branched; branches terete, oven, fastigiate, whitish or yellowish, the tips pale yellow; spores oblong-elliptical, yellowish, .0003 to .00045 inch long.

The Pale-yellow clavaria has a very thick but short, fleshy, white stem, which supports many smooth crowded branches. These divide and subdivide until the upper part of the plant is a dense mass of small branchlets, each one of which terminates in one to three blunt tooth-like points. The stem and branches are white or whitish, sometimes slightly tinged with yellowish hues, but the ultimate branchlets or points are a clear, pale yellow while young and fresh. When old the yellow tips are apt to fade, and then the whole plant is nearly uniformly colored. The flesh is white and its taste agreeable. The plants aro from two to five inches high, and the mass of branches is nearly as broad. It grows in thin woods and open places, and may be found from July to September.

Vittadini says that this clavaria is less esteemed in Italy than the Red-tipped clavaria. Roques says it furnishes a healthful food and one easy of digestion, that it is commonly eaten in France and in great domand in Germany. My own experiments in eating it lead mo to give it high commendation. Its flesh is tender and well flavored, and it seems to me nothing better could bo desired by the mycophagist. 
Clavaria botrytes Pers.

Red-TIPPEd Clataria.

Plate 39. Figs. 5 to $\%$.

Stem short, thick, fleshy, whitish, much branched; branches often somewhat rugose-wrinkled, repeatedly branched, the tips red; spores oblong-elliptical, .0005 to .0006 in. long.

The Red-tipped clavaria dilfers but little from the preceding species in size and structure, but is easily distinguished by the red tips of the branches. The color elsewhere may bo whitish or yellow or pinkish. When old the tips sometimes fade, and then it is less easy to separate this species frum the Pale-yellow clavaria. The branches are sometimes longitudinally wrinkled. It grows in thin woods and open places, and may be found in wet weather in July, Augrust and September. Nearly all mycologists agree in classing this among the edible species. They ascribe to it delicious qualities and an agreeable flavor. Unfortunately, it is not very common in our State.

\section{Clavaria cristata Pers. \\ Crested Clavaira. \\ Plate 39. Fizo. 8 to 12.}

Stem rather slender, eren, tenacious, stulfed, branched; branches dilated above, acutely incised or crested, the tips generally becoming brown with age; spores globose or broadly ellip. tical, white, .00025 to .0003 in. long.

The Crested clararia is smaller than either of the two species alreacy described, but it is much more abundant. It is not of ten more than two or two and a half inches high, but it often grows in tufts as broad as they aro high. It varies in color, but is commonly white or whitish. Sometimes it has a dingy look as if it had been smoked. Again it is faintly tinged with dull pink or creamy-yellow. It is easily recognized by the peculiar tips of the branches. These are rather slender and acute or pointed, and sometimes so numerous as to give a crested appearance to the apically-flattened branch they terminate. When old they usually turn brown or blackish-brown at the tips. Unusual forms of the plant occur in which these acute terminal branchlets are wanting. The branches then end abruptly in a blunt point. Perhaps theso forms are referable to $C$. coralloides, but that is described as having the tips of the branches acute. 
The Crested clavaria grows in woods and in open places. It is especially common in the hilly and mountainous districts of the State. It loves cool, shaded and moist places, and grows on naked soil or among mosses and sphagnum. It usually grows in groups, sometimes in lines, and it is so plentiful that it is not difficult in some localities to gather enough for the table in a short time.

\section{Poisonous and Unwholesome Fungi.}

As has already been stated, the most dangerous fungi appear to belong to the single genus Amanita, and probably most of the fatal accidents from mushroom poisoning are due to two or three species. The characters of the genus need not be repeated here. The prominent distinctive features of the species here described are indicated in the brief tabular statement annexed.

Cap warty, striate on the margin...............

A. muscaria.

Cap not warty, even on the margin................

1 Remains of the membranous wrapper closely pressed

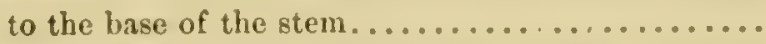

I Remains of the wrapper distant from the base of the

A. verna.

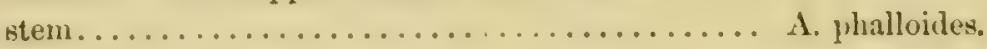

These plants are not ordinarily poisonous to handle, nor are they repulsive in taste or odor. They are clean and attractive in appearance, and the symptoms of poisoning that follow their use as food are slow in appearing.

On the other hand, those that are classed as unwholesome usually possess some character that may be taken as an indication of their unwholesomeness, though this is not always a sure guide to follow. Their toughness of texture, their nauseous and acrid taste, or their intolerable odor, will in most cases sound a note of warning.

A single species will here bo illustrated and described as a representative of this class of fungi. It is the Bitter boletus, Bolctus felleus.

\section{Amanita muscaria $L_{\text {. }}$}

Fro Amanita. False Orange.

Plate 42.

Pileus warty, slightly striate on the margin; lamelle white; stem annulate, bulbous thickened at the base where it is more or 
less scaly from the fragments of the ruptured volva; spores broadly elliptical, white, .0003 to $.000 \pm$ inch long.

The Fly amanita is our most common poisonous species. It is also very variable in size and in the color of its cap. It is generally a most showy and attractive plant. The cap is adorned with numerous white or yellowish warts, the remains of the upper part of the wrapper. It is more or less striated on its margin, but individuals sometimes occur in which the striations are very inconspicuous or even wholly wanting. The color is bright-red, scarlet or orange in the young plant, but this nearly always fades to yellow on the margin in the mature plant. In one variety the cap is wholly yellow, and in another it is white. The fading process often goes on until the orange and yellow hues are replaced by whitish ones. The warts of the cap are sometimes washed off by heary rains, so that it is possible to find specimens of this species without warts. The llesh is white, but except in white forms it is yellowish just under the epidermis. The gills are white, or in some cases slightly tinged with yellow. The same remark applies to the stem. 'This is furnished with a collar and terminates in a bulb at the base. This bulb is not broad and abrupt abore as in the Poison amanita, but is gradually narrowed into the stem so that it has a somewhat ovate form. It, as well as the base of the stem, is more or less scaly from the adhering fragments of the wrapper, the remains of which do not alhere in an entire membranous sheath as in the Orange amanita and Sheathed amanita. $\Lambda$ s in other species, the stem may be either stuffed or hollow.

Cap three to eight inches broad; stem four to six inches long; one-half an inch or more in thickness.

It grows both in woods and in open places and pastures. It occurs from June till the freezing weather of October or November.

Very diverse statements concerning the properties of this fungus have been recorded. While some hare attributed to it edible qualities, others have asserted that it is a most active poison and has caused numerous accidents by being confused with the Orange amanita. It is said to have caused death even when eaten in small quantities, and again it is said to have been eaten in abundance without any evil result. According to Quelet, 
it acts as a cathartic if eaten in small quantity, but causes death if eaten freely. One of my own correspondents assures mo that he has eaten of the yellow variety, Var. formosa, Fig. 6, without evil results, and that he regards it as rery good. But there is no disputing the fact that the species possesses intoxicating and poisonous properties. It has long had the reputation of possessing properties fatal to flies that sip its juice. This suggests the names muscaria, Fly amanita, Fly agaric and Fly killer by which it is known. I have myself secn the cap of a single specimen surrounded by a circle of lifeless flies that had sipped the viscid juice from its moist surface and fallen victims to its virulent properties before learing the place of thoir fatal repast.

Some have attempted an explanation of the contradictory statements concerning this plant by supposing that its poiconouz properties are not always dereloped, that in some localities or under some favorable circumstances it is harmless. This explanation violates our sense of the constancy of Nature, and is not at all satisfactory. In the case of my own correspondent, the caps were peeled before cooking. May it not be that much of the noxious quality resides in the epidermis and the riscid substance upon it, and that by discarding this the dish is rendered less dangerous? In some instances may it not bo true that it was eaten in too limited quantity to produce eril consequences? In some cases it is said that those who eat it freely and without harm boil it a long time in water and throw away the water. In this way, doubtless, much of the poison is abstracted. Long soaking in salt and water, also in vinegar, have been recommended as a means of rendering suspected or noxious species harmless, and may hare been practiced in some of the cases in which this fungus has been eaten with impunity.* Whatever may be the explanation of the contradictory statements, the only safo way is to consider this species as deleterious and aroid its use under all circumstances. There is no need of taking any risks with suspected species, since there are so many good ones against which no chargo of eril has ever been established.

- Gince this was writen another correspondent writes that he has eaten as many as four caps of the yellowish form of this species at one meal and without any evil consequences, and that the caps were not poeled. Thli makes pertinent the question, is this varlety, indeed, a diatinct atd harmless apecies? It scarcely zeems possible that the difrentent experiences are explainablo by reason of Individual Idianyerasy, or by variation in the propertles of the niant. 
IIt is said that some of the people of northern Asia make an intoxicating liquor of this fungus by steeping it in water.

Forms of this species occasionally occur which are wholly white or whitish. They are referable to Variety alba.

Amanita Frostiana, Frost's amanita, is found in more dense woods. It might easily be taken for a rery small form of the Mly amanita. Its cap is only one or tro inches broad, its gills and stemare often yellow, its collar is slight and often evanescent and the base of the stem is not scaly, the bulb being slightly margined by the remains of the wrapper.

\section{Amanita verna Bull. \\ Vernal Ayanita. \\ Plate 4l. Flgs. 4 to 7.}

Pilcus glabrous, eren on the margin, white, riscid when moist; lamellax white; stem annulate, white, floccose, stuffed or hollow, closely sheathed at the base by the remains of the membranous volva, bulbous; spores globose, .0008 inch broad.

The Vernal amanita scarcely differs from white forms of the Poison amanita except in the more persistent and more closely sheathing remains of the wrapper at the base of the stem. It is probably only a variety of that species, as most my'cologists now regard it, and it should be considered quiteas dangerous. I have not found it earlier than in July, although in Europe it is said to appear in spring, as its name implies.

\section{Amanita phalloides Fro \\ Poison Amanita. \\ Plates 10 and 41 . Figs. 1 to 3 .}

Pileus glabrous, eren on the margin, white, greenish ur brown; lamella white; stam annulate, abruptly bulbous at the base, the bulb slightly and loosely margined above by the remains of the volva; spores globose, white, .0003 in. broad.

The Poison amanita is rery variable in the color of the cap, and yet is so definite in its structural characters that only the most careless observer would be likely to confuse it with any other species. There is, however, a sort of deceptive character about it. It is very neat and attractive in its appearance and "looks as if it might be good enough to eat." This appearance 
is fortified by the absence of any decidedly unpleasant odor or taste, but let him who would eat it beware, for probably there is not a more poisonous or dangerous species in our mycological flora. To eat it is to invite death.

The cap is wholly destitute of warts and of striations on its margin. It varies in color, from white to a dark smoky-brown. In the most common form it is white or a very pale greenishyellow, as if it was white slightly tinged with yellow or greenish-yellow. I have never seen in it the decidedly green or olivegreen colors which it appears often to have in Europe, and which are often indicated in figures of this species. There are two brown forms, one having the cap grayish-brown, as in figures 1 and 2, the other having it a dark smoky-brown, as shown in figures 3 to 5. The forms having a grayish or grayish-brown cap sometimes have the center of the cap darker colored or almost black. In Europe there is a white form with a black center to the cap.

The gills are persistently white. They are rather broad, rounded at the end next the stem and free from it.

The stem is white in the white-cap forms, but in those having a dark-brown cap it is usually tinged with brown, but is paler than the cap. The same is true of the collar. These dark-col. ored forms are more frequent in the cool woods of mountainous regions than elsewhere. When young the stem may be stuffed with a cottony pith, but it becomes hollow with age. The bulb at the base of the stem is an important character and should always be taken into consideration in the identitication of the species. It is very abrupt, broad and distinct. Its breadth is often greater than its length. It is generally narrowly margined on the upper side by the remains of the wrapper. Sometimes this margin is reduced to a mere acute rim. It is distant from the stem, not closely presied as in the Vernal amanita, and is frequently split or notched.

'The cap is three to five inches broad, the stem three to six inches long and one-third to one-half an inch thick. The bulb is from one to one and a half inches broad.

The l'oison amanita grows in woods, groves, open places and bushy pastures, and may bə found from July to October. It is n common fungus. 
I suspect that fatal cases of mushroom poisoning are especially attributable to the Vernal amanita and the white forms of the Poison amanita. But such accidents could only occur through ignorance or gross carelessness, for the distinction between these and the common mushroom is plain and unmistakable. It may be exhibited as follows:

Poison amanita. Gills persistently white; stem equal to or longer than the diameter of the cap, with a broad distinct bulb at the base.

Common mushroom. Gills pink, becoming blackish-brown; stem shorter than the diameter of the cap, with no bull at the base.

From all forms of the edible Sheathed amanitopsis, the Poison amanita differs in its distinctly bulbous stem, in having a collar on the stem and in the absence of striations on the margin of the cap.

From the edible Reddish amanita, it is easily separated by the entire absence of any reddish hues or stains and of warts from its cap.

From the Smooth lepiota its distinct, abrupt and margined bulb at once distinguishes it.

\section{Boletus felleus Bull. \\ Bitter Boletur. \\ Plato 43.}

Pileus fleshy, convex above, glabrous or nearly so, grayishbrown, buff-brown, reddisb-brown or tawny, flesh white, taste bitter; tubes long, conrex in the mass in mature plants, at first whitish, becoming pale flesh color; stem equal or tapering upwards, usually reticulated at the top only, rarely wholly reticulated, commonly a little paler than the pileus; spores oblong-fusiform, pinkish, .0005 to .0007 inch long.

The Bitter boletus takes its name from the bitter flavor which its flesh persistently maintains. It is a common species, and one easily recognized by its reticulated stem and flesh-colored tubes taken in connection with its bitter taste.

The cap is rather thick, dry and smooth, but quite variable in color. This is generally some shade of brown tinged with red or yellow. The flesh is white, but when cut or broken and exposed to the air it sometimes assumes a pinkish tint. 
The mass of tubes is generally somewhat convex in the mature plant, though it may be plane in the young plant. This also sometimes assumes a pinkish stain where bruised.

The stem varies greatly in length and thickness, and is sometimes crooked and deformed. It is usually reticulated at the top only.

Cap one and a half to four inches broad; stem one to four inches long, one-third to two-thirds of an inch thick.

The Bitter boletus occurs in woods and in open places. A farorite place of growth is in a soil largely composed of decayed wood and other regetable matter. It is frequently found growing about much-decayed stumps and prostrate trunks of hemlock trees. It may be found from July to September.

The taste of the flesh in this Boletus, as well as in many species of Lactarius and Russula, is an important aid in the specific identification. In tasting fungi for this purpose care should betaken to select only fresh, sound specimens, and the part tasted should not be swallowed. 


\section{LIST OF PLATES ANI) SPECIES.}

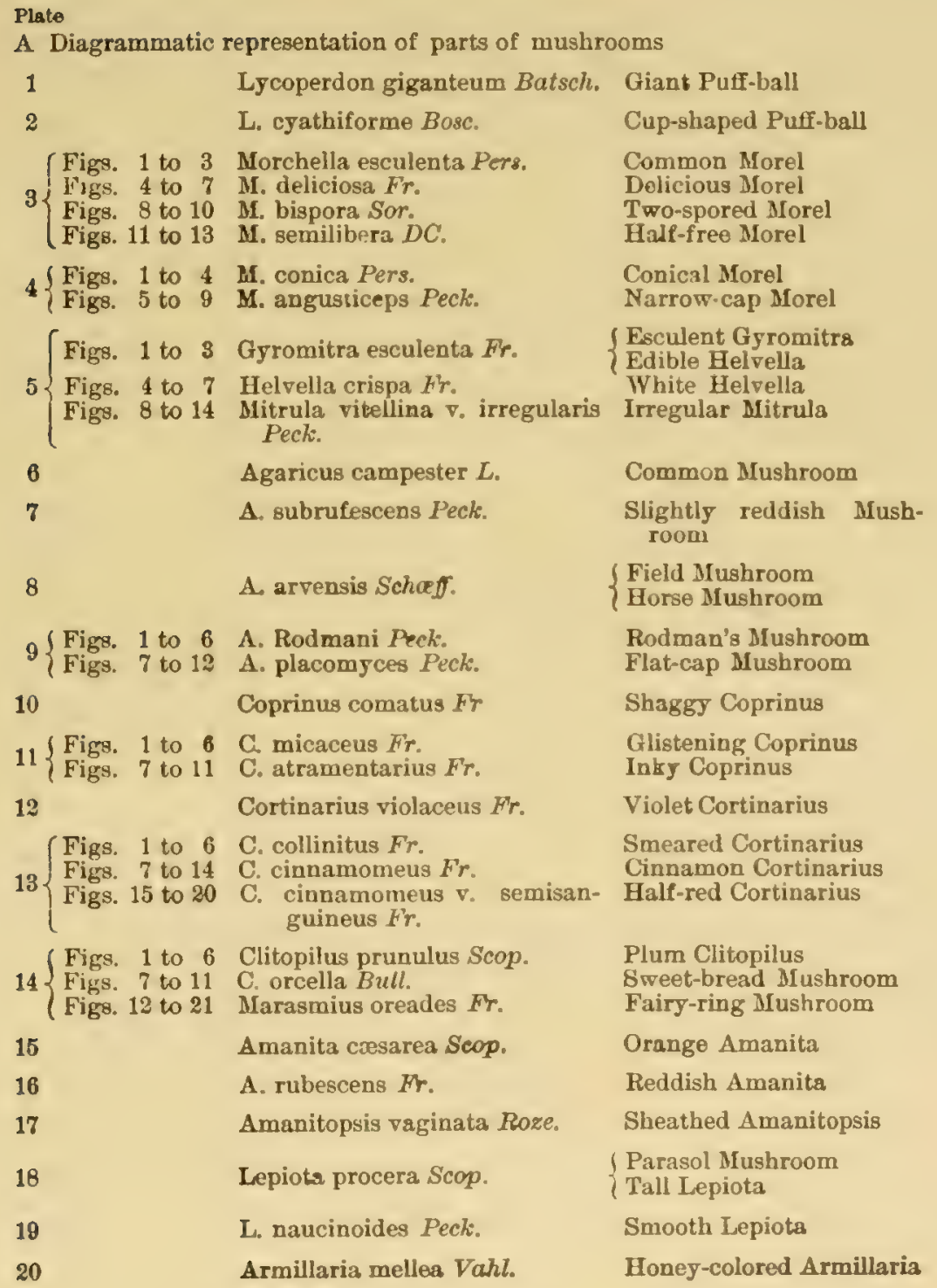


Plate

21 Figs. 1 to 5 Tricholoma transmutans Peck. Changing Tricholoma

21 Figs. 6 to 11 T. imbricatum $F r$. Imbricated Tricholoma

22

T. personatum $F r$.

Masked Tricholoma

23 Figs. 1 to 7 Clitorybe media Peck.

23 Figs. 8 to 13 C. nebularis Batsch.

Intermediate Clitocybe

Clouded Clitocybe

$24\left\{\begin{array}{lll}\text { Figs. } & 1 \text { to } 6 & \text { C. infundibuliformis Schaeff. } \\ \text { Figs. } & 7 \text { to } 10 & \text { Craterellus cornucopioides } P\end{array}\right.$

Funnel-form Clitocybe

$24 \begin{cases}\text { Figs. } 7 \text { to } 10 & \text { Craterellus cornucopioides Pers. Cornucopia Crater. Ilus } \\ \text { Figs. } 11 \text { to } 13 \text { Hydnum coralloides Scop. } & \text { Coral-like Hydnum }\end{cases}$

25

Clitocybe laccata Scop.

Laccate Clitocy be

26 Figs. 1 to 4 Pleurotus ulmarius Bull.

EIm Pleurotus

SOyster Pleurotus

Figs, 5 to 9 P.ostreatus $F r$.

\{ Oyster Mushroom

27

$28\left\{\begin{array}{l}\text { Figs, } 1 \text { to } 10 \\ \text { Figs, } 11 \text { to } 17\end{array}\right.$

P. sapidus Kalchb.

Figs. 11 to $17 \mathrm{H}$. pratensis $\mathrm{Fr}$.

Figs. 18 to 23 Paxillus involutus $F r$.

29

30

31

32

33 Figs. 1 to 6 Boletus subluteus Peck:

33 Figs. 7 to 12 B. luteus $L$.

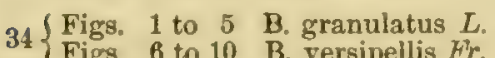

35

B. scaber Fr.

36 Figs. 1 to 7 B. castaneus Bull.

36 Figs. 8 to 12 B, edulis $B$ ull.

37 Figs. - 1 to 4 Polyporus sulphureus Fr.

37 Figs. 5 to 9 Fistulina hepatica $F r$.

38

Hydnum repandum $L$.

(Figs. 1 to 4 Clavaria flava Schaff.

39 Fign. 5 to 7 C. botrytes Pers.

(Figs. 8 to 1: C. cristata Pers.

40

Amanita phalloides $F r$.

$41\{$ Figs. 1 to 3 A. phalloides $\not\}$.

41 Figi. 4 to 7 A. verna Bull.

42

A. muscaria $L$.

Boletus telleus Bull.
Sapid Pleurotus

Vermilion Hygrophorus Meadow Hygrophorus

Involute Paxillus

Delicious Lactarius

f Orange Lactarius

Orange-brown Lactarius

Greenish Russula

Chantarelle

Small yellowish Boletus Yellow-brown Boletus

Granulated Boletus Orange-cap Boletus

Rough-stemmed Boletus

Chestnut Boletus

Edible Boletus

Sulphury Poly porus

Liver Fistulina

Spreading Hydnum

Pale-yellow Clavaria

Red-tipped Clasaria

Crested Clavaria

Poison Amanita

Poison Amanita (Whitish) Vernal Amanita

Fly Amanita

Bitter Boletus

\section{EXPLANATION OF PLATE $A$.}

Fig. 1 An Amanita; $c$ the pilers or cap; $m$ the striated margin of the cap; $g$ the lamella or gills; $a$ the annulus, ring or collar; \& the stem; $v$ the volva or wrapper; me the mycelium or spawn.

Fig. 2 A Boletus; $c$ the cap; $p$ the tubes or pores; $a$ the collar; $s$ the atem; me the mycclium. 
Fig. 3 A Hydnum; c the cap; $t$ the aculei or teeth; $s$ the stem; me the mycelium.

Figs. 4 to 8 Vertical sections of caps and the upper part of their stems showing the relations of gills to stems.

Fig. 4 Gills free from the stem; stem hollow.

Fig. 5 Gills adnexed; stem stuffed.

Fig. 6 Gills adnate; stem solld.

Fig. 7 Gills emarginate, also adnate and having a decurrent tooth.

Fig. 8 Gills decurrent.

Fig. 9 A plant with its cap umbonate, also squamose, and its stem bulbous.

Fig. 10 A plant with its cap umbilicate, its gills decurrent and its stem equal.

Fig. 11 A basidium with its four spores.

Fig. 12 An ascus containing eight spores.

PLATE 1.

LyCORERDON GIGANTEOY Butsch.

Giant Puff-ball.

Fig. 1 An immature plant; about one-half the natural size.

$\therefore$ 2 A mature plant with its rind abore breaking into fragments, falling away and exposing the dusty mass of spores; about half the natural size.

. 3 Two fragments of fllaments from the spore mass, magnifed about 400 diameters.

“4 Several spores, $\times 400$.

PLATE 2.

LYCOPERDON CYATHIFORME BOSC.

Cup-shaped Puff-ball.

Fig. 1 An immature plant.

‘ 2 A full-grown plant with even surface.

“ 3 A full-grown plant with the surface cracked into areas or broad spot-like scales.

. 4 A mature plant with the upper part of the rind breaking into fragments, falling away and exposing the purplish spore mass.

“5 The ragged cup-shaped base of an old plant after the upper part of the rind and the spore mass have been dispersed.

. 6 Vertical section through an inmature plant.

، 7 Two fragments of filaments frum the spore mass, $\times 400$.

“ 8 Seven spores, $\times 400$.

\section{PLATE 3.}

\section{Mobchella esculenta Pers.}

Fig. 1 A mature plant.

Common Morel.

.2 Vertical section through the center of a mature plant.

. 3 A spore sack containing eight spores, $\times 400$. 
Morchella deliciosa Fr.

Delicions Mrorel.

Figs. 4 and 5 Mature plants, two forms.

“ 6 Vertical section through the center of a mature plant.

‘ 7 A spore sack containing eight spores, $\times 400$.

Fig. 8 A mature plant.

Morcaella Bibrora Sor.

Two-spored Morel.

Vertical section through the center of a msturo plant.

“ 10 A spore sack containing two spores, $\times 400$.

Fig. 11 A mature plant.

MIORCHeLla SeMILibera DC.

Half-free Morel.

i 12 Vertical section through the center of a mature plant.

:6 13 A spore sack containing eight spores, $\times 400$.

\section{PLATE 4.}

Morchella conica Pers.

Figs. 1 and 2 Mature plants.

Conical Morel.

- 3 Vertical section through the center of a mature plant.

“ 4 A spore sack containing oight spores, $\times 400$.

Morctella Angusticeps Peck.

Narrow-cap Morel.

Figs. 5, 6 and 7 Mature plants of various forms.

“ 8 Vertical section through the center of a mature plant

“9 A spore sack containing eight spores, $X 400$.

PLATE 5.

GrRoutra esCULENTA Fr.

Esculent Gyromitra. Edible Helvella.

Fig. 1 A mature plant.

62 2 Vertical section through the center of a mature plant.

، 3 A spore sack containing eight spores, $\times \mathbf{4 0 0}$.

HeLVELIA CRISPA lir.

Figs, 4, 5 and 6 Mature plants of various forms.

67 s spore sack containing eight spores, $\times 400$.

Mitrula viteldiva Srec. var. ImRegularis Peck.

Irregular Mitrula.

Figs. 8 to 13 Mature plants of various forms.

- $14 \Delta$ spore sack containing eight spores, $\times 400$. 
PLATE 6.

AGARICUS CAMPESTER $L$.

Common Mushroom.

Fig. 1 A cluster of three joung plants, in one of which the veil has just separated from the margin of the cap, thereby revealing the gills.

، 2 and 3 Plants with their caps partly expanded and their gills yet pink-colored.

“4 4 mature plant with its rap fully expanded and its gills blackish-brown.

$\therefore 5$ Vertical section of the cap and upper part of the stem of an immature plant.

- b Vertical section of the cap and upper part of the stem of a mature plant.

، 7 Four spores, $\times 400$.

Fig. 8 An immature plant.

‘ $A$ mature plant.

. 10 Four spores, $\times 400$.

"ariety nORTENSIS.

\section{PLATE 7.}

AaAricos subrufescens Peck.

\section{Slightly Reddish Mushroom.}

Fig. 1 A young plant whose veil has just separated from the margin of the cap, revealing the whitish color of the gills.

“ 2 A cluster of four plants, two young, and two older ones with the caps partly expanded and the gills yet of a pinkish hue.

- 3 A single plant approaching maturity.

. 4 A mature plant whose gills have assumed the blackish-brown color.

“5 Vertical section of the cap and upper part of the stem of a young plant.

“6 Vertical section of the cap and upper part of the stem of a middle-aged plant.

. 7 Vertical section of the cap and upper part of the stem of a mature plant.

‘ 8 Four spores, $\times 400$.

، 9 Branching strings of mycelium.

PLATE 8.

AGARICUS ARVENSIS Schreff.

Field Mushroom. Horse Mushroom.

Fig. 1 A young plant with the veil just separated from the margin of the cap.

" 2 A plant with the cap partly expanded, showing the dingy pinkish hue of the gills. 
Fig. 3 A mature plant with the cap fully expanded and the gills of a blackishbrown color.

“4 Vertical section of the cap and the upper part of the stem of a young plant.

، 5 Vertical section of the cap and upper part of the stem of a mature plant.

i6 6 Four spores, $\times 400$.

\section{PLATE 9.}

Agaricos Rodmani Peck.

Fig. 1 A young plant.

Rodman's Mushroom.

“. 2 A plant with the cap partly expanded, showing the pinkish color of the gills.

، 3 A mature plant with the cap fully expanded.

، 4 Vertical section of the cap and upper part of the stem of an immature plant.

. 5 Vertical section of the cap and upper part of the stem of a mature plant.

"G Four spores, $\times 400$.

\section{Agaricus placomyces. Peck.}

\section{Flat-cap Mushroom.}

Fig. 7 A young plant with the veil just separated from the margin of the cap.

“ 8 A plant with the cap partly expanded.

“ 9 A mature plant with the cap fully expanded.

، 10 Vertical section of the cab and upper part of the stem of an immature plant.

“ 11 Vertical section of the cap and upper part of the stem of a mature plant.

“12 Four spores, $\times 400$.

PLATE 10.

Coprinus comatus Fir.

Fig. 1 A young plant.

$$
\text { Shaggy Coprinus. }
$$

.. 2 and 3 Immature plants with the cap beginning to split on the margin and the gills beginning to assume the pinkish and blackish hues.

“ 4 A mature plant with the margin of the cap much split and recurred and the gills blackened, deliquescing and dripping with an inky Iluid.

15 Vertical section of the cap and upper part of the stem of a young plant.

“ O Vertical section of the cap and upper part of the stem of a plant approaching maturity.

“7 Four spores, $\times 400$. 


\section{PLATE 11.}

Coprinus Micaceds Fr.

\section{Glistening Coprinus.}

Fig. 1 A cluster of seven immature plants.

“2 A mature plant showing the blackened gills.

. 3 A mature plant with the margin of the cap split and somerhat recurved.

- 4 Vertical section of the cap and upper part of the stem of an immature plant.

‘5 Vertical section of tho cap and upper part of the stem of a mature plant, the blackened deliquesciog gills dripping with an inky thuid.

“6 Four spores, is 400 .

\section{Cormines atramentar us Fr.}

\section{Inky Coprinus.}

Fig. 7 A cluster of four plants, one of them young.

“8 4 maturo plant.

“9 Vertical section of the cap and upper part of the stem of an immature plant.

- 10 Vertical section of the cap and upper part of tho stem of a mature plant, showing tho blackened dripping gills.

. 11 Four spores, $\times 400$.

\section{PLATE 12}

\section{Cortinamios Violacedes $\mathrm{Fr}$.}

Fig. 1 A young plant.

Violet Cortinurius.

. 2 A plant with the cap partly expanded.

“ 3 A plant with the cap partly expanded, showing the color of the gills.

“ 4 A plant with the cap fully expaniled.

“5 Vertical section of a cay and the upper part of the stem of an immaturo plant.

"6 Vertical section of the cap and upper part of the stem of a mature plant.

‘ 7 Four spores, $\times 400$.

PLATE 13.

Cortivarius collinites $F$ r.

Smeared Cortinarius.

Fig. 1 A young plant showing the webby veil.

.. 2 and 3 Immature plants showing the color of the roung gills.

“ 4 A mature plant with the cap fully expanded.

“ 5 Vertical section of the cap and upper part of the stem of a mature plant.

-6 6 Four sfores, $\times 400$. 
CortinariUs cinnamomeus fir.

Cinnamon Cortinarins.

Fir. 7 A young plant showing the webby veil.

- 8,9 and 10 Immature plants showing the color of the young gills.

“ 11 and 12 Mature plants showing the color of the mature gills.

- 13 Vertical section of the cap and upper part of the stem of a wature plant.

“ 14 Four spores, $\times 400$.

Variety SEMSAiGuLEUS Fr.

Half-red Cortinarius.

Fig. 15 A young plant showing the webby veil.

. 16 and 17 Immature plants showing the color of the young gills.

“ 18 A mature plant showing the solor of the mature gills.

. 19 Vertical section of the cap and upper part of the stem of a matured plant.

- 20 Four spores, $\times 400$.

PLATE 14.

Clitopilus prunduls Scop.

Plum Clitopilus

Fig. 1 A young plant.

.. 2 and 3 Mature plants, one having the margin of the cap wavy or irregular.

“ 4 Vertical section of the cap and upper part of the stem of a joung plant.

- 5 Vertical section of the cap and upper part of the stem of a mature plant.

-6 Four spores, $\times 400$.

Clitomilus orcella Bull.

Sucet-breal Ifushroom.

Fig. 7 A joung plant.

- 8 and 9 Muture plants.

- 10 Vertical section of the cap and upper part of the stem of a mature plant.

“ 11 Four spores, $\times 400$.

Marasurus orfades Fr.

Fuiry-ring Mushroom.

Fir. 12 A plant showing slight striations on the margin of the cap.

-. 12, 13, 11 and 15 Plants showing the usual color when fr. sh and moist.

. 16 and 17 Plants showing the usual color after the evaporation of the moisture.

“18, 10 and 20 Vertical sections of the caps and upper part of the stems of three plants of different forms or stages of developwent.

1. 21 Four spores, $\times 400$. 
PLATE 15.

AMANita CAsarea Scop.

Orange Amanita.

Figs. 1 and 2 Two young plants just emerged from the wrapper.

. 3 and 4 Immature plants with the caps partly expanded.

“ 5 A mature plant with the cap fully expanded and its margin faded to a yellow color.

"6 Vertical section of a cap and the upper part of its stem shorring the color of the flesh and gills and the cavity in the stem.

$\therefore \quad 7$ Four spores, $\times 400$.

PLATE, 16.

AManita RUBEscens $F r$.

Fig. 1 A young plant.

Reddish Amanita.

. 2 A plant with the cap partly expanded.

، 3 A plant with the cap fully expanded and with reddish stains on the gills indicating places where they have been bruised or wounded.

. 4 Vertical section of a cap and the upper part of its stem.

- 5 A plant from whose cap the warts have disappeared.

- 6 A plant from whose cap the warts have mostly disappeared and on the margin of which are slight striations.

- 7 Vertical section through the center of a plant.

8 Four spores, $\times 400$.

\section{PLATE 17.}

Amasitopsis vaginata Roze.

Sheathed Amanitopsis.

Fig. 1 A young plant.

Variety FoLFA (Sheel.)

- 2 and 3 Plants with the cap partly expanded, one having an umbo on the cap and the tawny tint to the wrapper.

. 1 A plant witls the cap fully expanded and darker colored in the center.

$$
\text { Variety LITIDA (Pers.) }
$$

-5 5 joung plant with two fragments of the wrapper adhering to the cap.

-6 A plant with the cap partly expanded.

$\therefore \quad$ - A plant with an umbonate cap fully expanded.

. \& Vertical section of a cap and the upper part of its stem.

- 9 Four spores, $\times 400$.

PLATE 18.

LEPIOTA PROCERA Scop.

Parasol Mushroom. Tall Lepiota.

Fig. 1 A young plant.

$\therefore 2$ A mature plant.

- 3 A smaller mature plant with unspotted stem.

. 4 Vertical section of a cap and the upper part of its stem.

. 5 Four spores, $\times 400$. 
PLATE 19.

LEPIOTA NAUCINOIDES Peck.

Fig. 1 A joung plant.

Smooth Lepiota.

' 2 and 3 Plants with the cap partly expanded.

“ 4 A plant with the central part of the cap tinged with yellow.

“ 5 A plant with the cap fully expanded and centrally tinged with a smoky-brown hue.

“ 6 Vertical section of a cap and the upper part of its stem.

‘ 7 Four spores, $\times 400$.

PIATE 20.

Armilladia mellea Vahl.

Honey-colored Armillaria.

Fig. 1 A young plant growing on decaying wood.

. 2 A cluster of five plauts, one of them quite young and having its gills concealed by the reil.

“ 3 A mature plant with the cap striated on the margin and centrally darker colored.

، 4 A mature plant with the cap brown anl striated on the margin.

“ 5 Vertical section of a cap and the upper part of its stem.

"6 Four spores, $\times 400$.

\section{Variety GLABRA Gill.}

Fig. $7 \Lambda$ plant with tho cap glabrous and yellowish.

“ 8 Vertical section of the cap and upper part of the stem of a mature plant.

\section{PLATE 21.}

Tricholoma transmutaxs Peck.

Fir. 1 A young plant.

Changing I'richoloma.

. $2 \Lambda$ plant with the cap partly expanded.

“ $3 \Lambda$ cluster of two young plants and one mature plant, tho latter showing the gills spotted with reddish-brown.

$\therefore 4$ Vertical section of a cap and the upper part of its stem.

.. 5. Four spores, $\times 400$.

\section{TrICHOLOMA IMBRICATUM $\mathrm{Fr}$.}

Fin. 6 A young plant.

Imluricuted Tricholuma.

. 7 A plant with the cap partly expanded.

“ \& $\mathrm{A}$ mature plant showing spots on the gills.

.. ! Vertical section of the cap and upper part of the stem of a young plant.

. 10 Vertical section of the cap and upper part of the stem of a mature plant.

- 11 Four spores, $\times 400$. 


\section{PLATE 22.}

Tricholomia PERSONATUM Fr.

Fig. 1 A young plant.

Masked Tricholoma.

، 2 A plant with the cap partly expanded.

“ 3 A plant with the cap fully expanded.

، 4 Vertical section of the cap and upper part of the stem of a young plant.

“5 Vertical section of the cap and upper part of the stem of a mature plant.

‘6 Four spores, $\times 400$.

Variety BULBOSUs Peck.

Fir. 7 A plant with the cap partly expanded.

$\therefore 8$ A plant with the cap fully expanded.

PLATE 23.

Clitocya meda l'eck.

Fig. 1 A young plant.

Intermediate Clitocybe.

‘ 2 A plant with the cap partly expanded.

- 3 and 4 Mature plants.

“5 Vertical section of the cap and upper part of the stem of an immature plant.

- 6 Vertical section of the cap and upper part of the stem of a mature plant.

“ 7 Four spores, $\times 400$.

Cutoctbe nemoratis Batsch.

Fig. 8 A young plant.

Clouded Clitocybe.

“9 An immature plant.

“ 10 A mature plant.

- 11 Vertical section of the cap and upper part of the stem of an immature plant.

- 12 Vertical section of the cap and stem of a mature plant.

“ 13 Four spores, $\times 400$.

PLATE 24.

Clitocrbe infundibuliforms Sehceff.

Fig. 1 A young plant.

Hunnel-form Clitocybe.

، 2 and 3 Mature plants, one showing more fully the upper surface of the cap.

“4 A mature plant with a wary margin to the cap.

“5 Vertical section through the center of a mature plant.

$\therefore 6$ Four spores, $\times 400$. 


\section{Craterellus cornucopioldes Pers. Cornucopia Craterellus.}

Fig. 7 A cluster of threo plants of different degrees of development.

* 8 A single mature plant.

: 9 Vertical section of a small plant.

“ 10 Four spores, $\times 400$.

\section{IYDNUM CORALLOTDES Scop. \\ Coral-like Hydnum.}

Fig. 11 A plant growing from a piece of wood.

“ 12 A branch with its branchlets and spines.

. 13 Four spores, $\times 400$.

\section{PLATE 25.}

\section{Clitocybe LacCata Scop.}

\section{Laccate Clitocybe.}

Figs, 1, 2 and 3 Plants showing the usual color when fresh and moist.

6 4 and 5 Plants showing the paler color of the caps when dry.

، 6 and 7 Vertical section of the cap and upper part of the stems of two plants of diferent form.

" 8 Four spores, $\times 400$.

6 9 and 10 Two plants of a larger form, their caps yet fresh and moist.

“ 11 A plant from swhose cap the moisture has evaporated.

“ 12 Vertical section of a cap and the upper part of its stem.

“13 Four spores, $\times 400$.

Variety striatula Peck.

Figs. 14, 15 and 16 Three plants whose caps are yet moist and show the marginal striations.

“ 17 A plant whose cap is dry and paler.

‘ 18 Four spores, $\times 400$.

\section{Variety Pallidifolia Peck.}

Figs. 19 and 20 Plants whose caps are yet moist.

“ $21 \Lambda$ plant whose cap is dry and paler.

- 22 Vertical section of a cap and the upper part of its stem.

\section{Variety AMETIXSTINA Bolt.}

Figs. 23, 24 and 25 Three plants with their caps yet fresh and moist.

¿26 A plant whose cap is dry and paler.

27 Four spores, $\times 400$.

\section{PLATF, 26.}

Plifurotus vimarius Bull.

Fig. 1 An immaturo plant.

\section{Elm Pleurotus.}

“2 A mature plant showing the central coloration and spotting some. times scen on tho cap. 
Fig. 3 Vertical section of the cap and upper part of the stem of a mature plant.

“4 Four spores, $\times 400$.

Pleurotus ostreatus Fr.

Oyster Pleurotus.

Fig. 5 A cluster of plants growing from decaying wood.

“ 6 A plant showing the upper surface of the cap.

‘ 7 A plant showing the lower surface of the cap.

- 8 Vertical section of a plant.

. 9 Four spores, $\times 400$.

\section{PLATE 27.}

Pleurotus sapidus Kalchb.

\section{Sapid Pleurotus.}

Fir. 1 A cluster of three plants growing from decaying wood.

“ 2 A clister of four plants branching from a common base.

. 3 A plant of reddish-brown color showing the upper surface of the cap.

. 4 A plant showing the lower surface of the cap.

“ 5 A small pale plant with a lateral stem, the upper surface shown.

. 6 Vertical scction of a plant.

. 7 Vertical section of a cluster of three plants.

“ 8 Four spores, $\times 400$.

- 9 Color of the spores as seen in a mass on white paper.

\section{PLATE 29.}

\section{HYOROPHORUS MINTATUS $F r$.}

Fi:. 1 A young plant.

Vermilion Hygrophomes.

- 2,3 and 4 Various forms of mature plants.

.5 A cluster of four plants.

- 6 Vertical section of the cap and upper part cf the stem of a small plant.

‘ 7 Vertical section of the cap and upper part of the stem of a larger plant with a hollow stem.

، 8 Four spores, $\times 400$.

Fig. 9 A young plant.

Variety LUTESCENS Peck:

-10 A mature plant.

Hygrophorus pratensts Fr.

Fig. 11 A young plant.

Meadow Hugrophoms.

"12,13 and 14 Forms of mature plants.

“ 15 and 16 Vertical sections of different forms of mature plants.

‘ 17 Four spores, $\times 400$. 


\section{Paxillus Involutus Fr.}

Fig. $18 \Lambda$ young plant.

Involute Paxillus.

“ 19 An immature plant showing the involute margin of the cap.

“20 $\mathrm{\Lambda}$ mature plant showing spots on the stem and gills where they have been bruised.

“21 $\Lambda$ plant with an eccentric stem.

“ 22 Vertical section through the center of a plant.

“2 2 Four spores, $\times 400$.

\section{PLATE 29.}

\section{Lactarius deliciosts $F r$.} Delicious Lactarius.

Fig. $1 \Lambda$ young plant.

"6 $2 \Lambda$ plant with the cap partly expanded.

“ 3 A plant with the cap fully expanded and somewhat funnel-shaped, the gills wounded at 3 .

“4 An old plant faded and tinged with green.

i5 5 Part of a vertical section through the center of the cap and upper part of the stem of a mature plant, showing the orange-colored juice oozing from a wound in the gill at $5 \mathrm{a}$.

i6 Four spores, $\times 400$.

\section{PLATE 30.}

\section{LACTARIOS Volemes Fir.}

Orange Lactarius.

Fig. 1 ^ young plant.

“ $2 \Lambda$ plant having a small umbo in the center of the cap.

6 3 A plant with a broadly conrex cap.

6 $4 \Lambda$ plant with the cap somewhat funnel-shaped.

65 A large plant with the cap broadly funnel-shaped, and the gills wounded, discolored and dripping the white milk at 52.

“6 $\Lambda$ plant with the margin of the cap corrugated or wrinkled on its surface.

i 7 Vertical section of the cap and upper part of the stem of a small plant, a drop of the white juice issuing from a wound in the gill at 7 a.

18 Four spores, $\times 400$.

\section{PLATE \&}

RUssuta VIREscess Fr.

Fig. 1 A young plant.

Greenish Russula.

" 2 A plant with the cap partly expanded.

¿ 3 and 4 'wo plants with the caps slightly striate on the margin, one mature and the cap fully expanded.

65 A mature plant with the cap fully expandet, split in two places on tho margin and yellowish-green in tho center.

"f Vertical section of the cap and upper part of the stem of a plant whoze cap is consex.

" ? Vertical section of the cap and upper part of the stem of a plant whose cap is centrally depressed.

1. 8 Four spores, $\times 400$. 
PLATE 32.

Canthareluos cibarios Fr.

Chantarelle.

Figs. 1, 2, 3, 4 and 5 Plants of various sizes and shapes.

" 6 A plant with the margin of the cap wavy.

“ 7 A stout plant with the cap somewhat funnel-shaped.

“ 8 Vertical section through the center of a plant.

"6 9 Four spores, $\times 400$.

PLATE 33.

Boletus sUblutets Peck.

Small yellowish Boletus.

Fig. 1 A young plant with the tubes or hymenium yet concealed by the veil.

" 2 An immature plant showing the yellow color of the tubes.

¿ 3 and 4 Mature plants showing the ochraceous color of the tubes.

“5 Vertical section of the cap and upper part of the atem of a mature plant.

$\therefore 6$ Four spores, $\times 400$

Boletes I.UTEus $L$.

Tellou'ish-brown Boletus.

Fig. 7 A young plant with the tubes jet concealed by the veil.

" 8 A plant whose veil has just separated from the margin of the cap.

$\therefore 9$ and 10 Mature plants.

“ 11 Vertical section of the cap and upper part of the stem of a mature plant.

“ 12 Four spores, $\times 400$.

PI,ATE 34

BoLETUS GRANULATUS $L$.

Fig. 1 A young plant.

Cramulated Boletus.

- 2 anct 3 Mature plants duffering in the shape and color of the caps

$\therefore 4$ Vertical section of the cap and upper part of the stem of a mature plant.

$\because 5$ Four spores, $\times 400$.

Fig. 6 A young plant.

BOTETUS VERSTPELIS Fr.

Urange-cap) Boletus.

$\therefore 7$ A plant with the dots on the stem of the same color as the cap.

" 8 A plant with the dots on the stem of different colors,

" 9 Vertical section of the cap and upper part of the stem of a mature plant.

" 10 Four spores, $\times 400$.

\section{PLATE 35.}

BOLETUS SCABER $\mathrm{Fr}$.

Rough-stemmed Boletus.

Figs. 1 and 2 Young plants with differently colored caps.

$\therefore 3$ A plant with a white cap.

“ 4 A mature plant having a reddish cap. 
Fir. is Ammature plant having an ash-colored cap.

.. fo $\Lambda$ mature plant with a blackish-brown cap.

“. i A plant with a brown cap.

.. \& Vertical section of the cap and upper part of the stem of a plant.

“ 9 Four spores, $\times 400$.

\section{PLATE 36.}

BOLETUS CANTANEUS Bull.

\section{Chcstnut Boletus.}

Fig. $1 \Lambda$ young plant showing the whitish tubes.

-. 2 and 3 Mature plants.

، 4 A nature plant with the margin of the cap slightly curved upwards.

، 5 Vertical section through the center of a young plant.

“6 6 Vertical section through the center of a mature plant.

.. 7 Four spores, $\times 400$.

Boletus EDULIS Bui.

Edible Boletus.

Fin. $8 \Lambda$ young plant showing the white tubes.

‘9 $\Lambda$ mature plant of small size.

، 10 A mature plant of medium size.

. 11 Vertical section of the cap and upper part of the stem or a mature plant.

- 12 Four spores, $\times 400$.

\section{PLATE 37.}

POLYPORUS SULPIUURES Fr.

Sulphury Polyporus.

Fig. 1 A cluster of four plants growing from decaying wood.

. $2 \Lambda$ single plant showing the upper surface of the cap and the yellow freshly grown margin.

، 3 Vertical section of a plant.

“ 4 Four spores, $\times 400$.

\section{Fistuma mepatica lir.}

Liver Fistulina.

Fig. 5 A plant showing the upper surface of the cap.

- 64 plant showing the lotrer surface of the cap.

. 7 Lateral view of a plant growing from decayed wood.

.. 8 Vertical section of a plant showing reddish streaks in the flesh.

1.9 Four spores, $\times 400$.

\section{PLATF 38.}

HYDNUM RFisnus $T_{\text {A }}$.

\section{Spreading IIydnum.}

Fir- 1 and 3 Plants whose caps are of a pale color.

. 2 and 4 Tlants whose caps are of a reddish color.

.. 5 Vertical section of the cap and upper part of the stem of a plant.

" 6 Four spores, $\times 400$. 
Variety RUFESCENS (Pers.)

Fig. 7 A plant whose cap is somewhat wavy on the margin.

" 8 A plant whose cap is more regular.

" 9 Vertical section of the cap and upper part of the stem of a plant.

'10 Four spores, $\times 400$.

\section{PLATE 39.}

Fig. 1 A young plant.

\section{Crataria flaya Schred.}

Pale-ycllow Clavariu.

" 2 A full-grown plant.

" 3 One of the principal branches with its branchlets.

"4 Four spores, $\times 400$,

Fig. 5 A young plant.

Clatatala botrytes Pers. Rcd-tipped Clavaria.

"6 A full-grown plant.

“ 7 Four spores, $\times 400$.

\section{Clavaria cristata l'crs}

Crested Clararia.

Figs, 8 and 9 Plants with few branches.

" $10 \Lambda$ plant with many branches and a dingy whitish color.

" 11 A mature plant in which the tips of the branches have assumed a brown coior.

" 12 Four spores, $\times 400$.

\section{PLATE 40.}

AManita piallondes $F r$.

Poison Amanita.

Fig. 1 A young plant with the cap slightly expanded, and of a gray ish-brown color.

" $2 \Lambda$ mature plant with the grayish-brown cap fully expanded and blackislh-brown in the center.

" 3 A very young plant just loursting from its wrapper, two fragments of which still adliere to the cap.

" 4 A plant with its blackish-brown cap partly expanded.

“ 5 A mature plant with its blackish-brown cap fully expanded.

“6 Vertical section through the center of an immature plant.

“ 7 Vertical section of the cap and upper part of the stem of a mature plant.

“ 8 Four spores, $\times 400$.

\section{PLATE 41.}

AManita irhalloides $F \%$.

Poison imanita.

Fig. 1 A plant with its whitish cap partly expanded.

" 2 A plant with its whitish cap fully expanded.

- 3 Vertical section through the conter of a mature plant. 


\section{Amanita verna $F r$.}

Vernal Almanita.

Fin. 4 A young plant just emerging from its wrapper.

.. .) An immature plant with the cap slightly expanded.

- 6 I mature plant with the cap fully expanded.

“ 7 Four spores, $X 400$.

\section{PLATE 42.}

Amavita Mescaria $L$.

Fly Amanita.

Fig. 1 A young plant just breaking from its wrapper.

.. 2 A plant with its red cap partly expanded.

“ 3 A mature plant with its cap fully expanded and faded to yellow on the striated margin.

. 4 Vertical section of a part of the cap and upper part of the stem of a mature plant.

. 5 Four spores, $\times 400$.

\section{Variety FORMOSA Fr.}

Fig. 6 A plant with its jellow cap partly expanded.

PLATE 43.

BOLETUS FELLETS Bull.

\section{Bitter Boletus.}

Fifi. 1 A young plant.

" 2 A young plant showing the color of the young tubes.

". 3 and 4 MIature plants with stems of different shapes.

. $5 \Lambda$ mature plant with tho stem reticulated to the base.

"6 Vertical scetion of the cap and upper part of the stem of a mature plant.

-7 Four spores, $\times 400$. 


\title{
CORRECTIONS OF PLATES.*
}

\author{
PIAA'TE 1.
}

Fig. 2. The exposed inner substance shown in the upper part of the figure is too black; it should be dingy-olivaceous.

\section{PLATE 6.}

Figs. 7, 10. The spores should be brown, not pink.

\section{PIAA'TE 8.}

Fig. 5. The gills should be blackish-brown, as in figure 3.

Fig. 6. The spores should be brown, not pink.

\section{PLAT'E 13.}

Figs. 2, 3. The gills should have no pink tint.

Fings. 7 to 12. There should be no stripes on the caps.

\section{PI $\Lambda$ TE 14}

Fig. 21. The spores should be white.

PIA'T' $1 \%$.

Fig. 9. The spores should be white.

\section{PISATE 19.}

Fig. 7. The spores should bo white.

\section{PIATE 24.}

Figs. 1, 2, 3, 4. The upper surface of the cap is too pale.

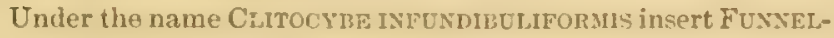
FORM ClitTOCYAE.

\section{PILTE 28.}

Figs. 8, 17. The spores should be white, not pink.

\section{PLATE 29.}

Fig. 4. The upper surface of the cap should have a dull greenish tint.

PLATE 30.

Fig. 8. The spores should be white.

- Tbe fallure of the artist to follow the sopy aud currected proof closely makes necessary several corrections. 
PIATE 34.

Fig. 10. The spores should be brown, not pink.

\section{PLATE 35.}

Fig. 2. The stem should be dotted as in the other figures.

Figs. 3, 4, 5, 6, 8, 9. The tubes and spores should have no pink hues.

For the name SOABER read SCABER.

\section{PLATE 36.}

Fig. 4. The lower surface of the cap should be yellowish.

Fig. 7. The spores should be yellowish, not pink. 


\section{N D EX.}

(Synonyms are in italies.)

\begin{tabular}{|c|c|}
\hline 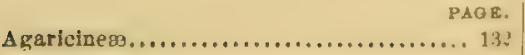 & ntinued). \\
\hline 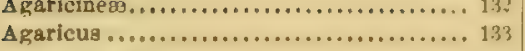 & \\
\hline arvensis................................ 119 & 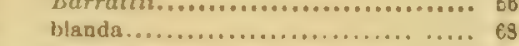 \\
\hline vester.......................... 13it & 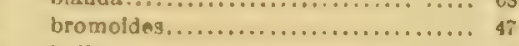 \\
\hline $\operatorname{ces} \ldots \ldots \ldots \ldots \ldots \ldots \ldots \ldots \ldots, 11 z$ & ullata $\ldots \ldots \ldots \ldots \ldots \ldots \ldots \ldots$ \\
\hline 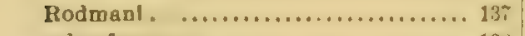 & 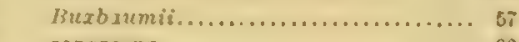 \\
\hline 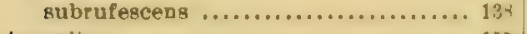 & canescens ........................ \\
\hline manita $\ldots \ldots \ldots \ldots \ldots \ldots \ldots \ldots \ldots \ldots \ldots, 155$ & capillaris ........................... \\
\hline 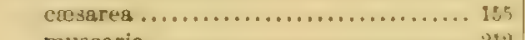 & Caregana..................... \\
\hline$\ldots \ldots \ldots \ldots \ldots \ldots \ldots \ldots \ldots \ldots \ldots \ldots \ldots \ldots, 212$ & castanea $\ldots \ldots \ldots \ldots \ldots \ldots \ldots$ \\
\hline 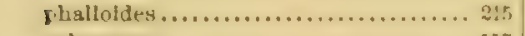 & cephaloidea .................... \\
\hline $3 \ldots \ldots \ldots \ldots \ldots \ldots \ldots \ldots \ldots \ldots \ldots, 157$ & crphale ghora $\ldots \ldots \ldots \ldots \ldots \ldots \ldots$ \\
\hline 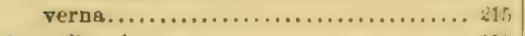 & chr $r$ r rhiza $\ldots \ldots \ldots \ldots \ldots \ldots \ldots \ldots$ \\
\hline 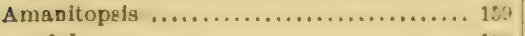 & Collinsil ........................... \\
\hline 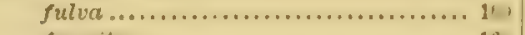 & 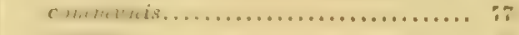 \\
\hline n $\ldots \ldots \ldots \ldots \ldots \ldots \ldots \ldots \ldots \ldots \ldots \ldots, 16,1$ & cintmisa $\ldots \ldots \ldots \ldots \ldots \ldots \ldots \ldots \ldots \ldots$ \\
\hline$\left.\ldots \ldots \ldots \ldots \ldots \ldots \ldots \ldots \ldots \ldots \ldots \ldots, 1 r_{j}\right)$ & connidea.....$\ldots \ldots \ldots \ldots \ldots \ldots \ldots$ \\
\hline .......................... 160 & 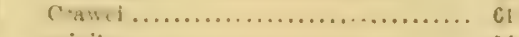 \\
\hline …...................... 159 & ta................................ \\
\hline gellea........................ 161 & 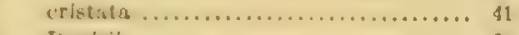 \\
\hline sliug . ....................... & Darl-il $\ldots \ldots \ldots \ldots \ldots \ldots \ldots \ldots \ldots \ldots \ldots \ldots$ \\
\hline …......................... 17 & 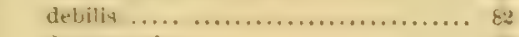 \\
\hline 1s.......................... 1i & mposita................... \\
\hline Hy $\ldots \ldots \ldots \ldots \ldots \ldots \ldots \ldots \ldots \ldots \ldots, 17$ & a $\ldots \ldots \ldots \ldots \ldots, \ldots \ldots \ldots, \ldots$ \\
\hline 1e $3 \ldots \ldots \ldots \ldots \ldots \ldots \ldots \ldots \ldots$ 17 & gan $\ldots \ldots \ldots \ldots \ldots \ldots \ldots$ \\
\hline ta........................... 14. & is $\ldots \ldots \ldots \ldots \ldots \ldots \ldots \ldots \ldots$. \\
\hline$\ldots \ldots \ldots \ldots \ldots \ldots \ldots \ldots \ldots \ldots, 171$ & distirlat ......................... \\
\hline 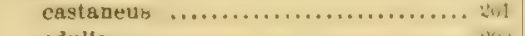 & 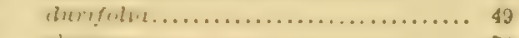 \\
\hline 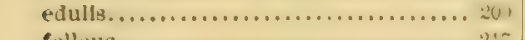 & $\ldots \ldots \ldots, \ldots, \ldots, \ldots, \ldots$ \\
\hline 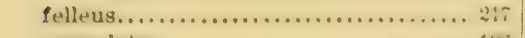 & Ionsli ..................... \\
\hline 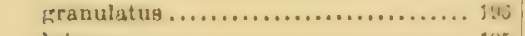 & s......................... \\
\hline 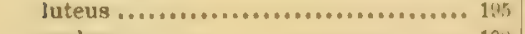 & ga.......... \\
\hline 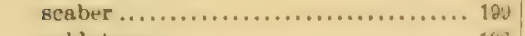 & mis...... \\
\hline 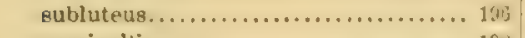 & $\ldots \ldots \ldots \ldots \ldots \ldots \ldots \ldots$, \\
\hline$\ldots \ldots \ldots \ldots \ldots \ldots \ldots \ldots \ldots \ldots \ldots+128$ & s............. \\
\hline as clbarius ........................ 120 & $\ldots \ldots \ldots \ldots \ldots \ldots \ldots \ldots \ldots \ldots$, \\
\hline$\ldots \ldots \ldots \ldots, \ldots, \ldots, 21$ & fulliculats ....................... \\
\hline 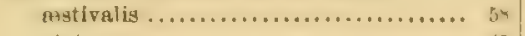 & sa $\ldots . . . \ldots \ldots \ldots \ldots \ldots \ldots \ldots .$. \\
\hline$\ldots \ldots$ 15 & fusera $\ldots \ldots \ldots \ldots \ldots \ldots \ldots \ldots$ \\
\hline cens. ... & n............ \\
\hline 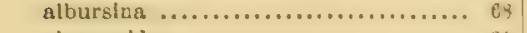 & glaucodea .................... \\
\hline 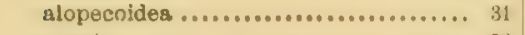 & llims.......................... \\
\hline$\ldots \ldots .52$ & ularis........................ \\
\hline $18 \ldots \ldots \ldots \ldots \ldots \ldots \ldots \ldots \ldots \ldots, 5 z$ & 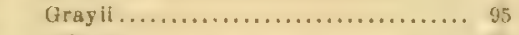 \\
\hline 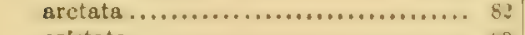 & 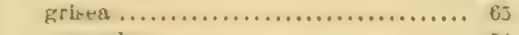 \\
\hline 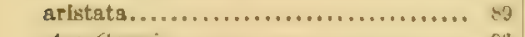 & ks nandra.................... \\
\hline 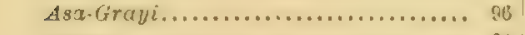 & 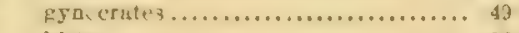 \\
\hline 64 & \\
\hline $\mathrm{B} \varepsilon$ & ............. \\
\hline
\end{tabular}




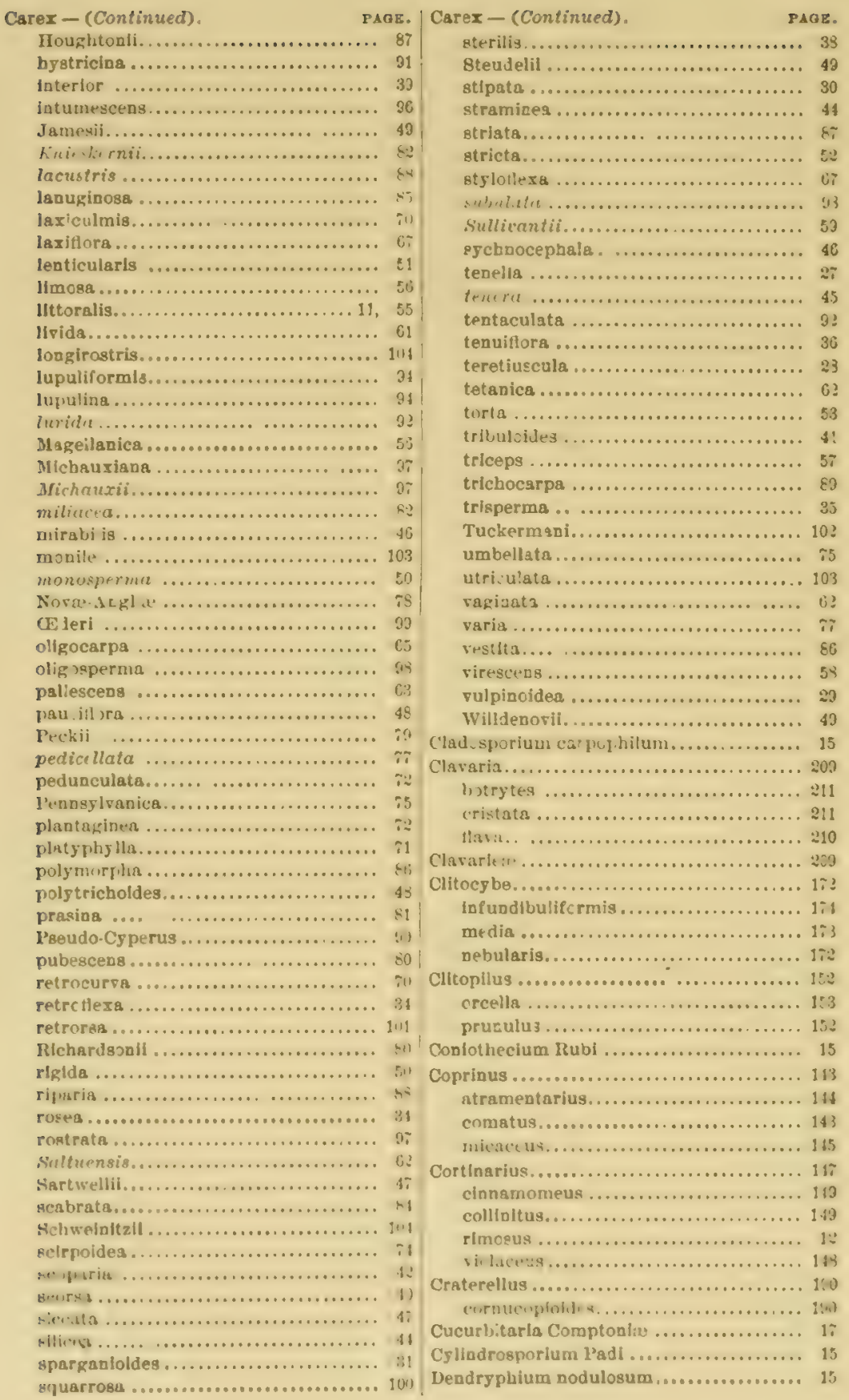




\begin{tabular}{|c|c|}
\hline iaporthe robusts ...................... & dellcio \\
\hline 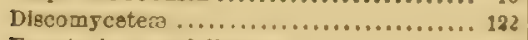 & ats....... \\
\hline erlollatum................ 17 & la $\ldots \ldots \ldots \ldots \ldots$ \\
\hline atica........................ 301 & 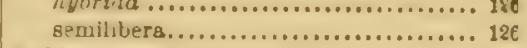 \\
\hline asterom 5 ceten ....................... 119 & ergla sobolifera.............. \\
\hline n...................... 131 & Ochrosporm........................ \\
\hline$\ldots \ldots \ldots \ldots \ldots \ldots \ldots \ldots \ldots, 131$ & clplens.................... \\
\hline$\ldots \ldots \ldots, \ldots \ldots \ldots \ldots \ldots, 131$ & tre................ \\
\hline ns................... & clutus................... \\
\hline a. $\ldots \ldots \ldots \ldots \ldots \ldots \ldots, 124$ & $\ldots \ldots \ldots \ldots \ldots \ldots \ldots$ \\
\hline$\ldots \ldots \ldots \ldots \ldots \ldots \ldots \ldots \ldots \ldots$ & 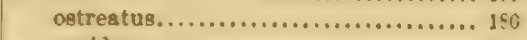 \\
\hline$\ldots \ldots \ldots \ldots \ldots \ldots \ldots \ldots, 123$ & …....... \\
\hline is $\ldots \ldots \ldots \ldots \ldots \ldots$ is & \\
\hline . $\ldots \ldots \ldots \ldots \ldots \ldots \ldots \ldots \ldots$ 2n & Douglagefl. ............. \\
\hline ........................ & a $\ldots \ldots \ldots \ldots \ldots \ldots \ldots \ldots$ \\
\hline $\ldots \ldots \ldots \ldots \ldots \ldots \ldots \ldots \ldots$, & $\ldots \ldots \ldots \ldots$ \\
\hline & Iphureus....... \\
\hline 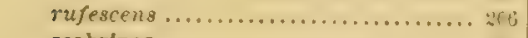 & ta $\ldots \ldots \ldots \ldots \ldots$ \\
\hline 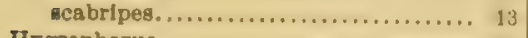 & terophyllus.... \\
\hline$\ldots \ldots \ldots \ldots \ldots \ldots \ldots \ldots \ldots, 14 !$ & Jare... \\
\hline$\ldots \ldots \ldots \ldots \ldots \ldots \ldots \ldots \ldots+1$ & ............... \\
\hline$\ldots \ldots \ldots \ldots \ldots \ldots \ldots+1, n$ & (.......... \\
\hline$\ldots \ldots \ldots \ldots \ldots \ldots \ldots, 131$ & q......... \\
\hline $88 a \ldots \ldots \ldots \ldots \ldots \ldots, 11$ & $1 . . . . \ldots \ldots \ldots$ \\
\hline$\ldots \ldots \ldots \ldots \ldots \ldots \ldots \ldots \ldots \ldots \ldots \ldots+1$ & aureleola....... \\
\hline$\ldots \ldots \ldots \ldots \ldots \ldots \ldots \ldots \ldots \ldots 155$ & veearum ............... \\
\hline$\ldots \ldots \ldots \ldots \ldots \ldots \ldots \ldots \ldots \ldots \ldots \ldots$ & $\ldots \ldots \ldots \ldots \ldots \ldots$ \\
\hline ...................... 10 & $u^{2} \ldots \ldots \ldots \ldots \ldots$ \\
\hline (................... 16: & blas ......... \\
\hline$\ldots \ldots \ldots \ldots \ldots \ldots \ldots \ldots \ldots \ldots, \ldots \ldots 1$ & ola....... \\
\hline n.................. $1: 3$ & tris $\ldots \ldots \ldots \ldots$. \\
\hline n................. 19 & . $\ldots \ldots \ldots \ldots \ldots \ldots \ldots$ \\
\hline 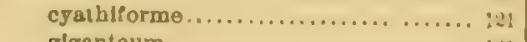 & Hrum....... \\
\hline$\ldots \ldots \ldots \ldots \ldots \ldots \ldots \ldots \ldots 121$ & oullatum. \\
\hline vatum. ................ 10 & ............. \\
\hline e ....................... 19: & a $\ldots \ldots \ldots \ldots$ \\
\hline$\ldots \ldots \ldots \ldots \ldots \ldots \ldots \ldots \ldots 133$ & m $\ldots . .$. \\
\hline$\ldots \ldots \ldots \ldots \ldots \ldots, \vdots$ & $\ldots \ldots \ldots \ldots$ \\
\hline$(\ldots \ldots \ldots \ldots \ldots \ldots \ldots \ldots \ldots \ldots$ & $n s \ldots \ldots \ldots \ldots \ldots$ \\
\hline & Hepatlcas....... \\
\hline$\ldots \ldots \ldots \ldots \ldots$ & (n.... \\
\hline & \\
\hline
\end{tabular}


12 




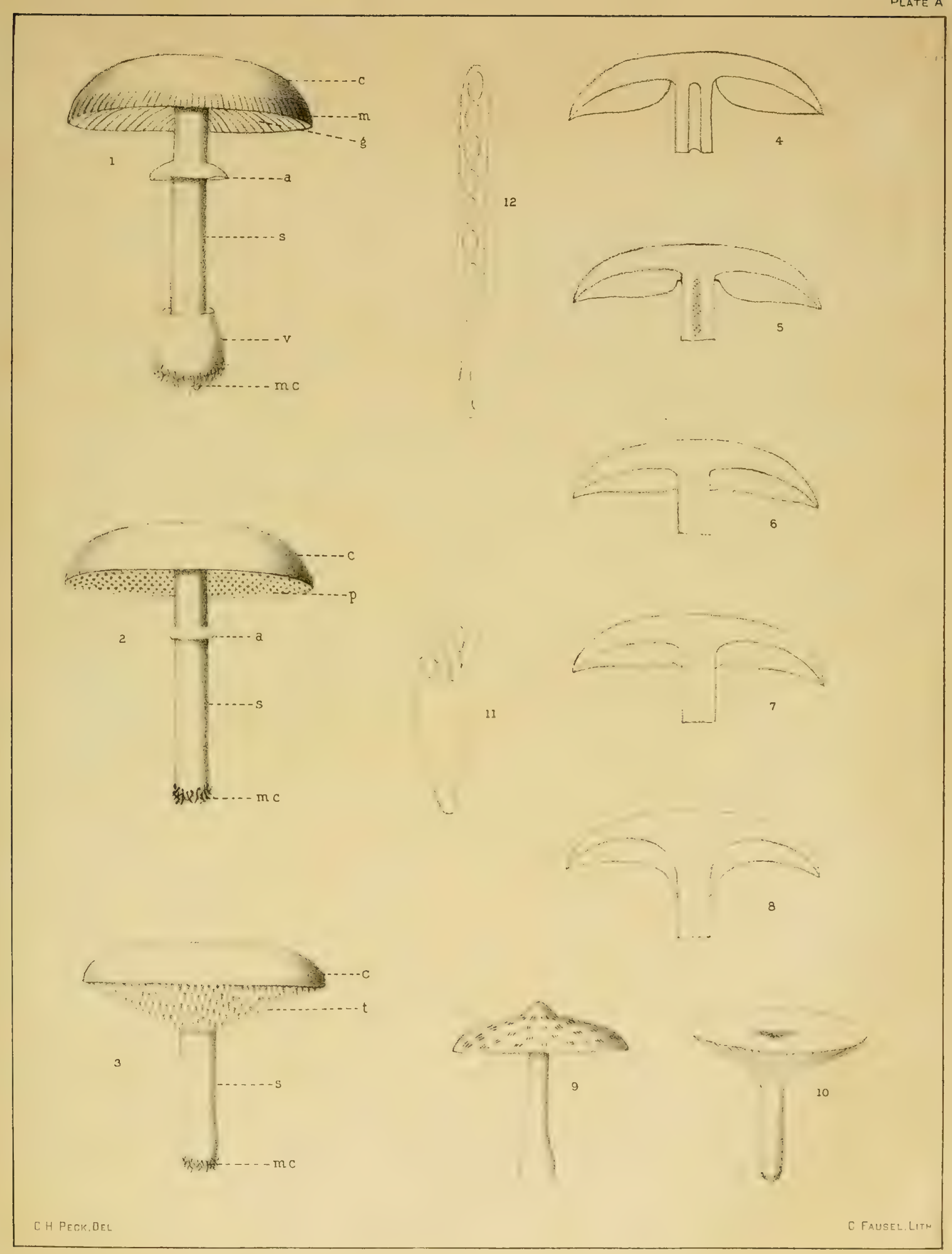





\section{EDIBLE FUNGI.}
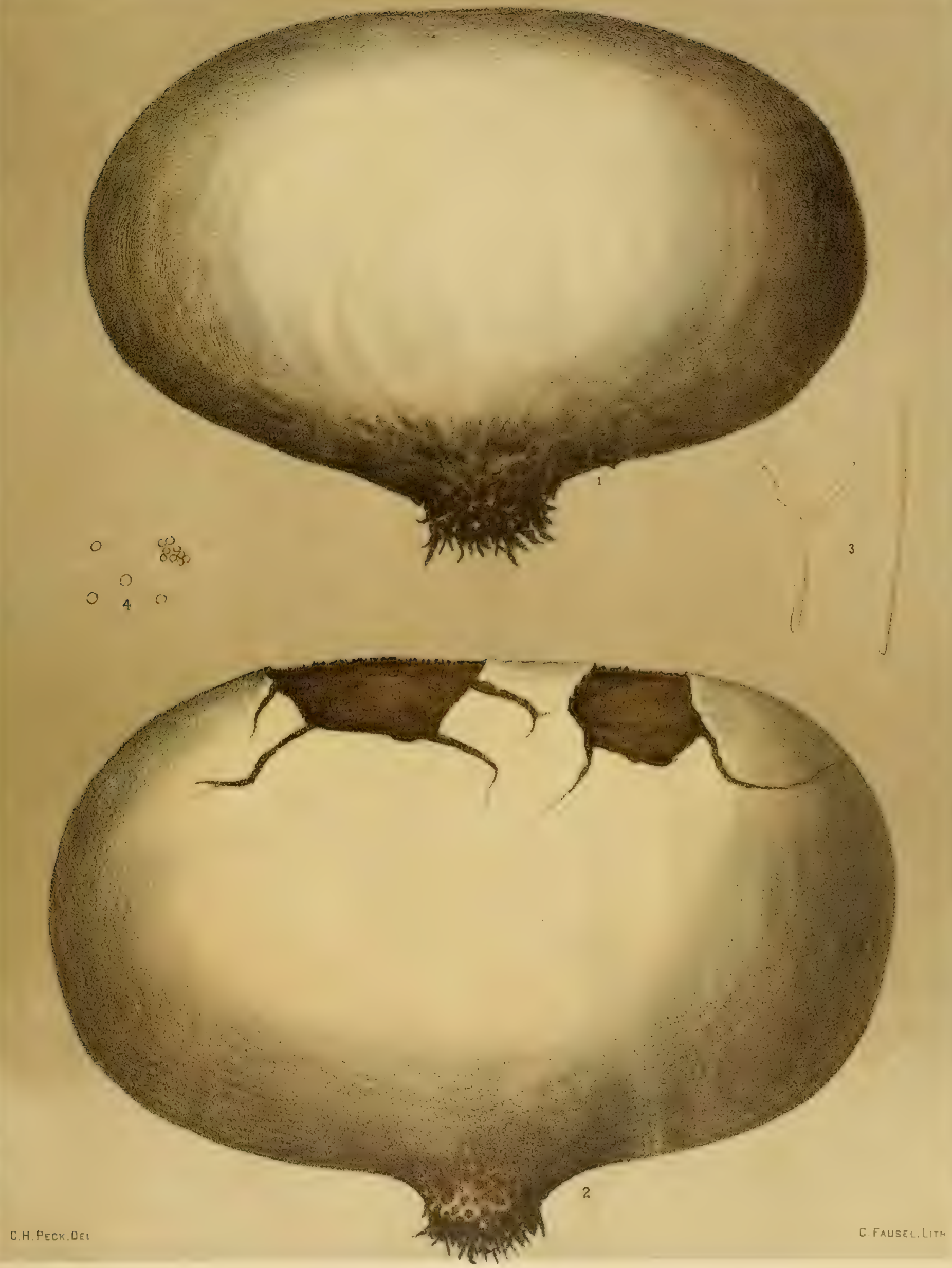

LYCOPERDON CICANTEUM BATSEM GIANT PUFF-BALL. (FIGS. 1 \& 2 ONE-HALF MATURAL GIZE) 



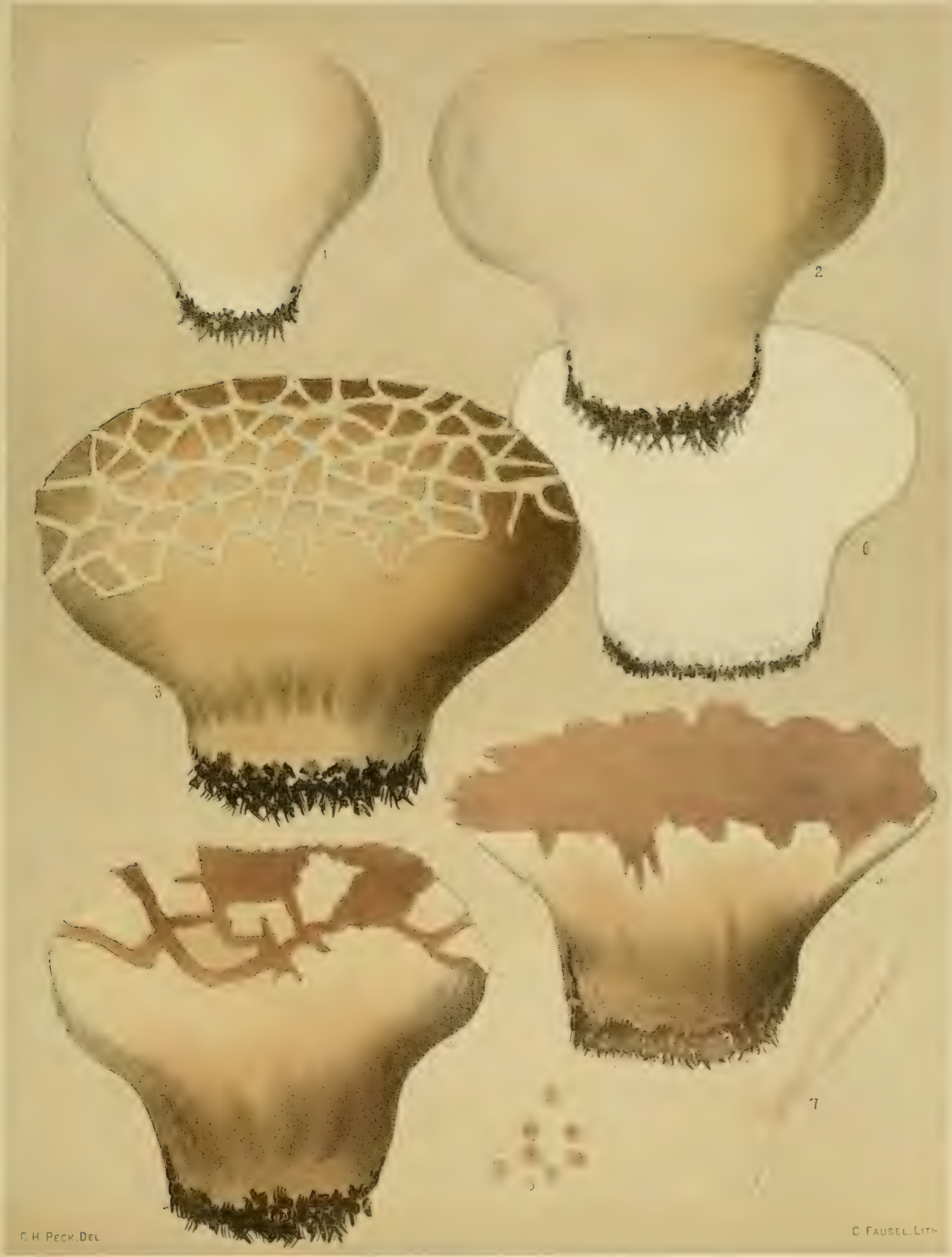





\section{EDIBLE FUNGI.}

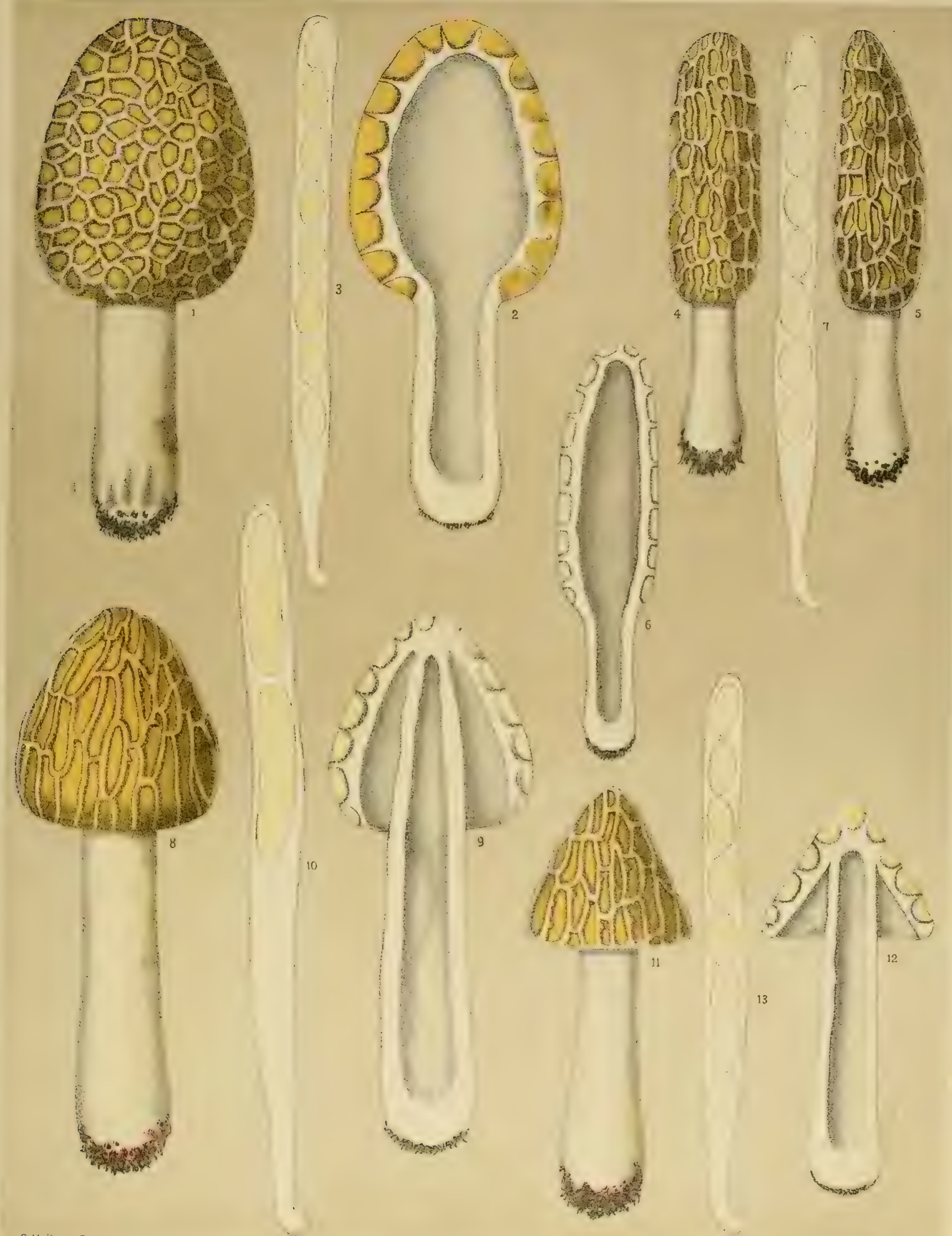

FigG. 4 TO 7 MORCHELLA DELICIOSA FR. DELICIOUS MOREL.

Fios. 11 To 13 MORCHELLA SEMILIBERA FH. HALF-FREE MOREL 



\section{EDIBLE FUNGI.}
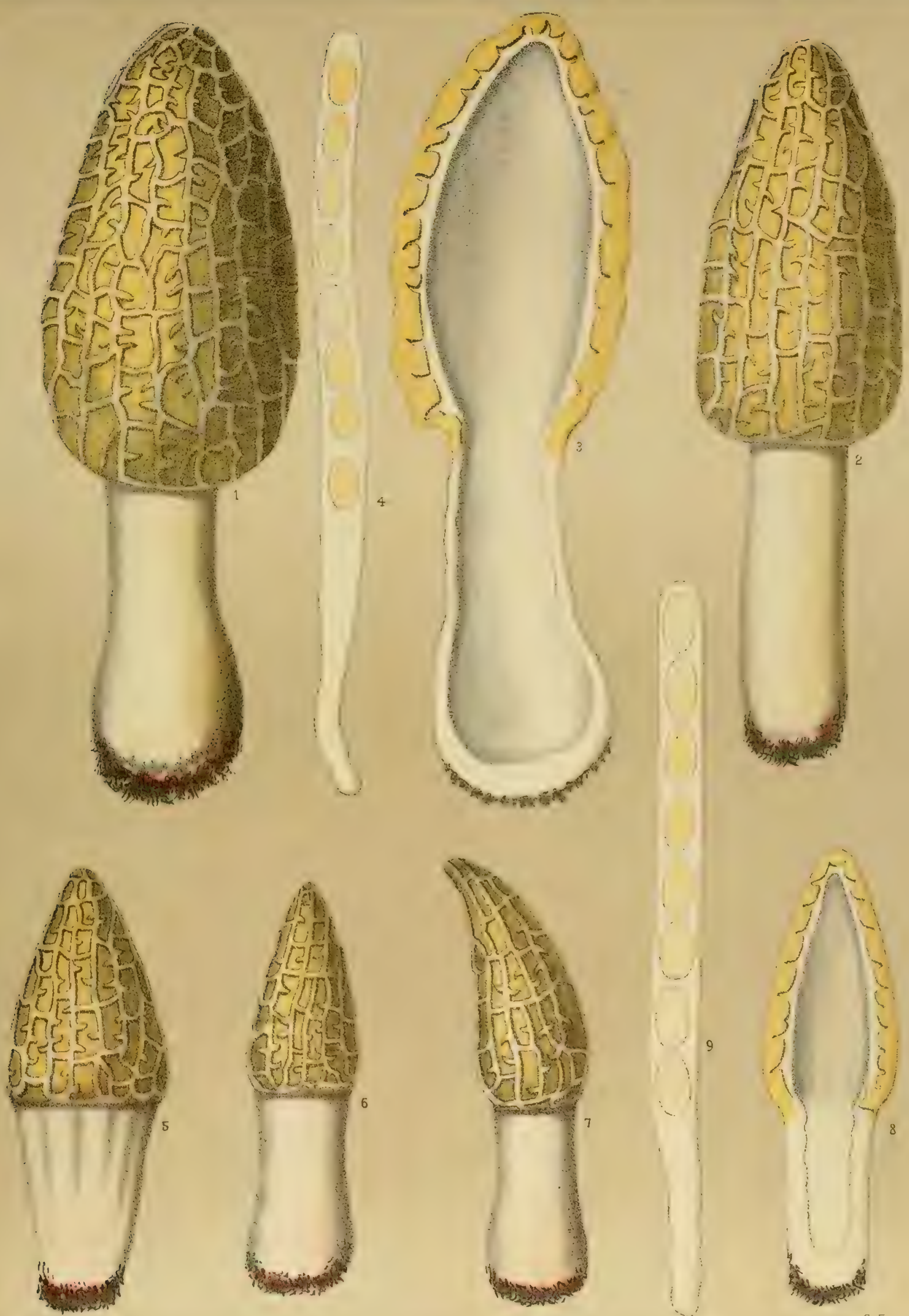



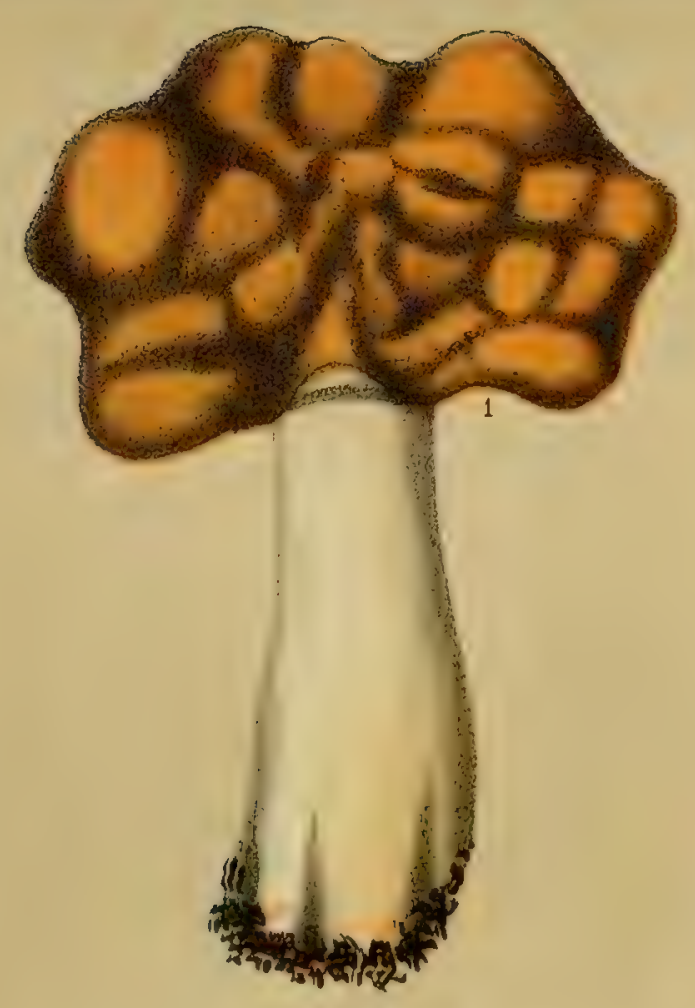

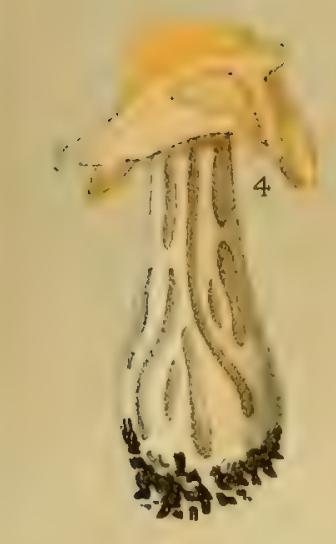

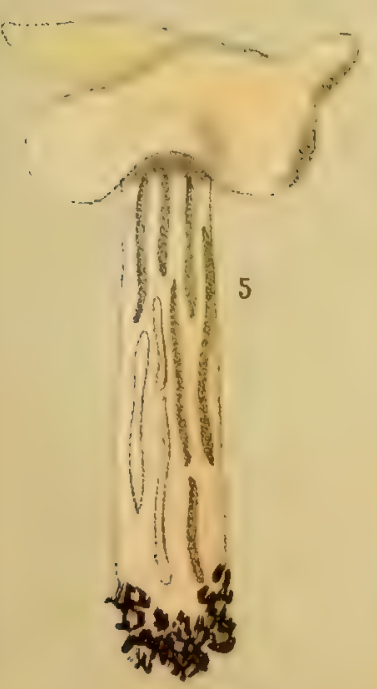

C H PECh,DEL
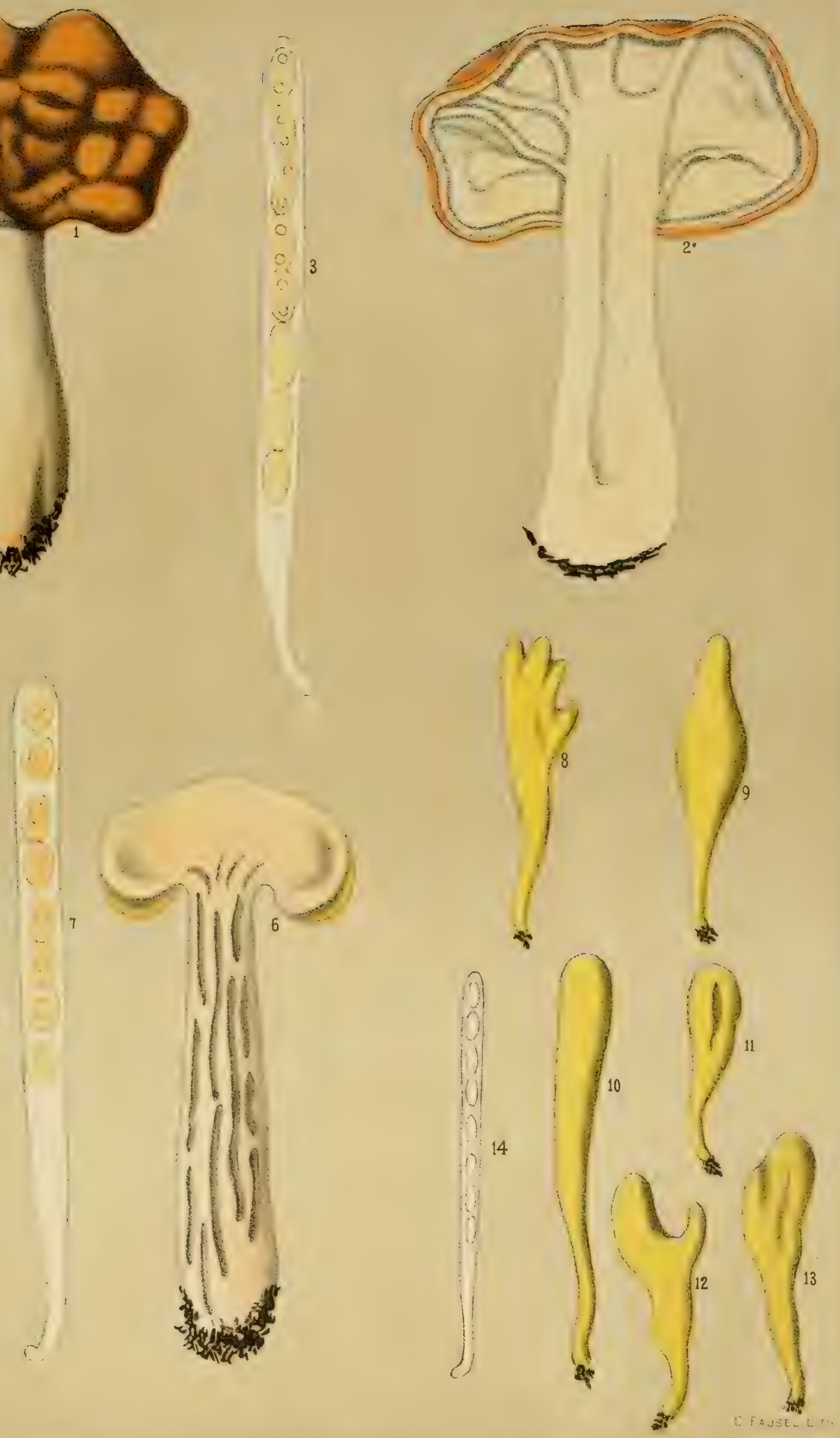



\section{EDIBLE FUNGI.}

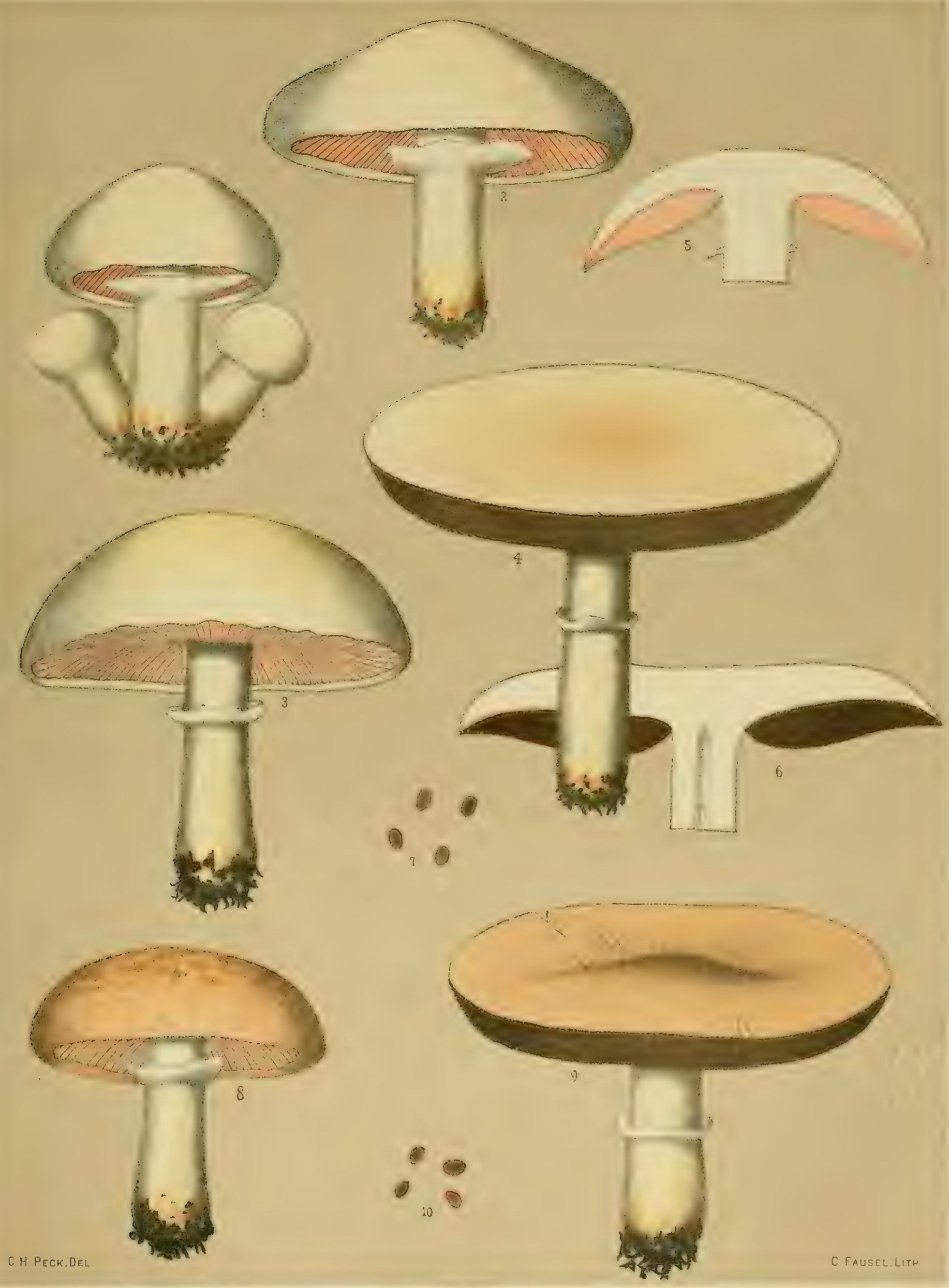





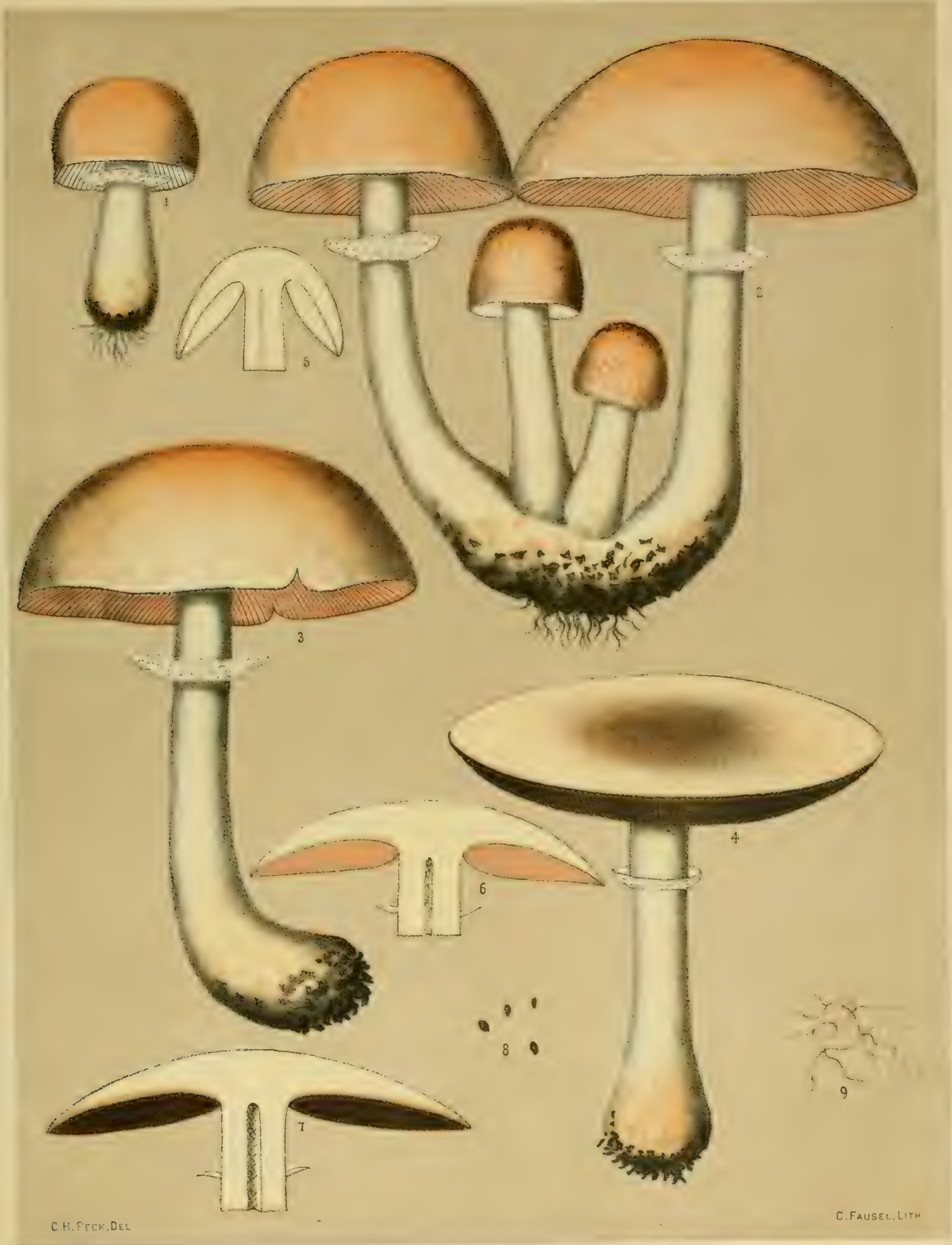





\section{EDIBLE FUNGI.}

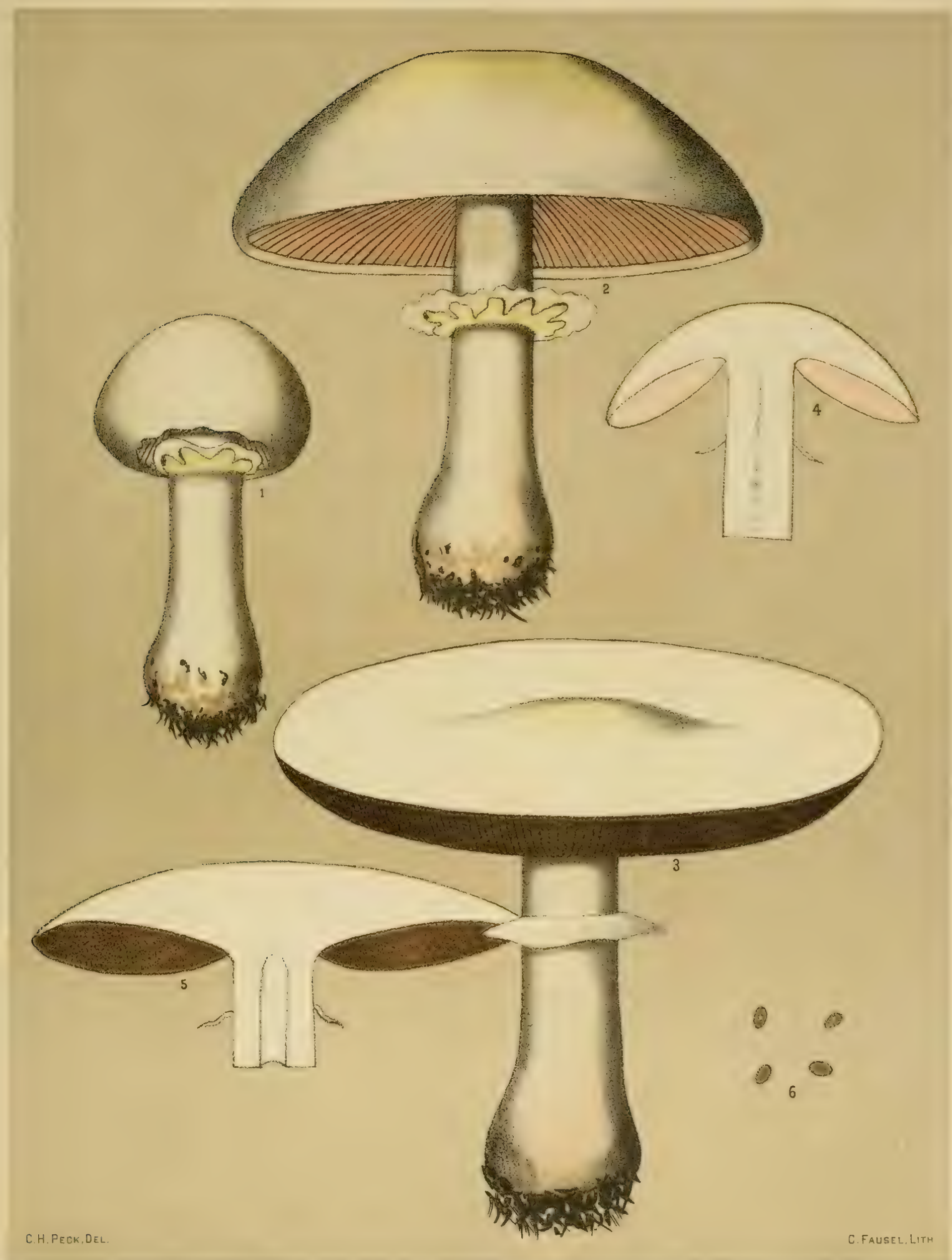





\section{EDIBLE FUNGI.}

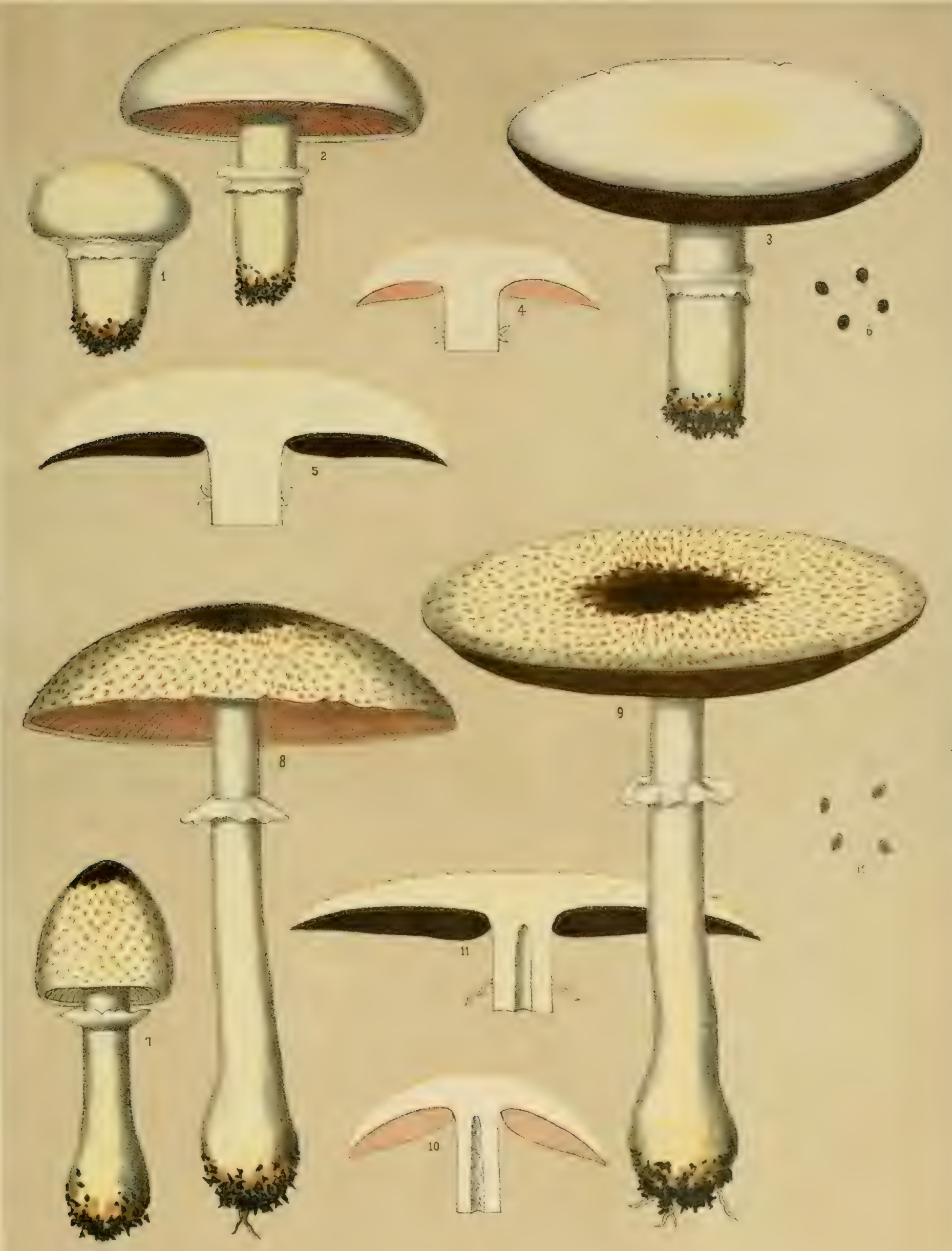





\section{EDIBLE FUNGI.}
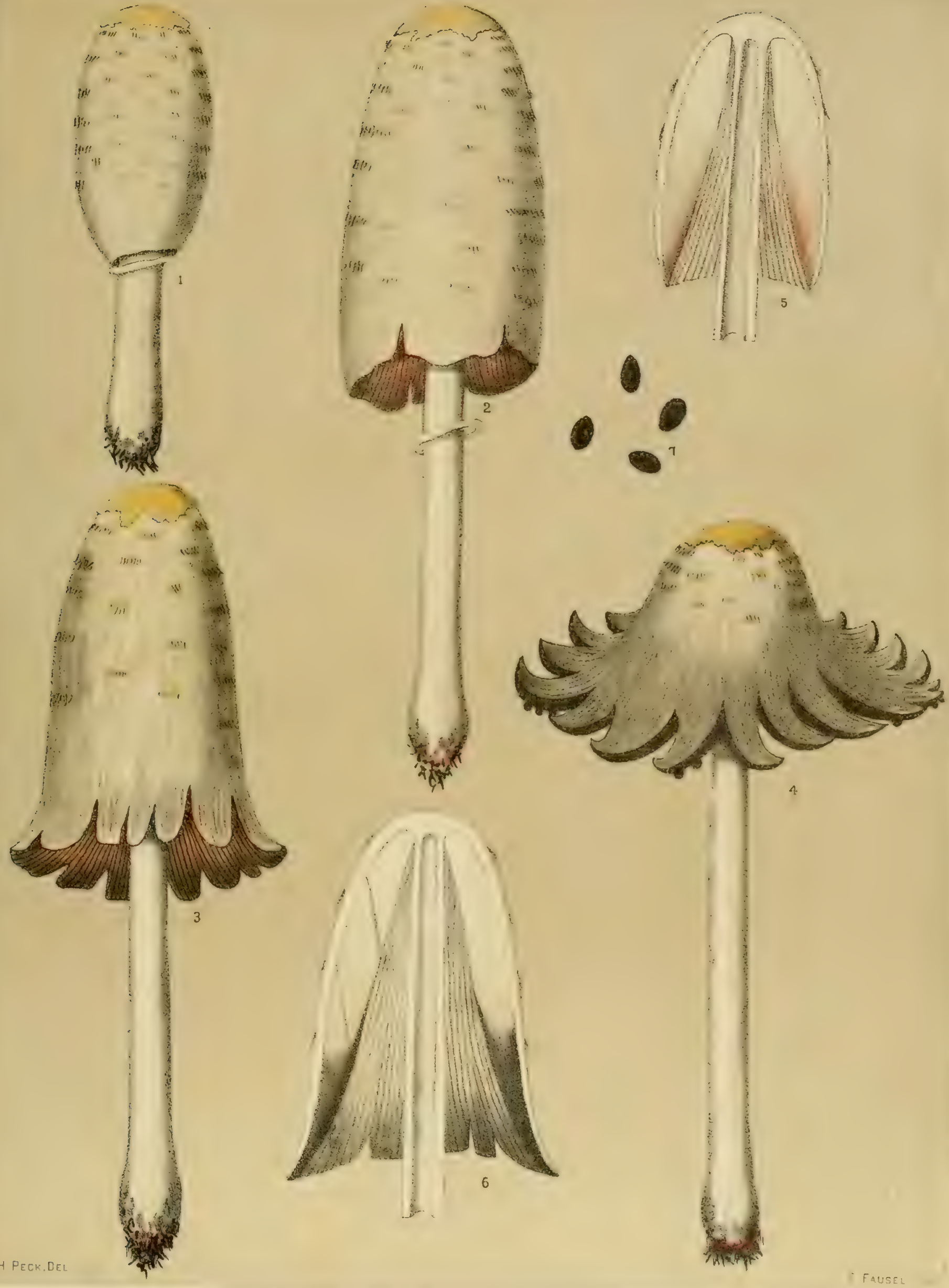

COPRINUS COMATUS

SHAGGY COPRINUS 



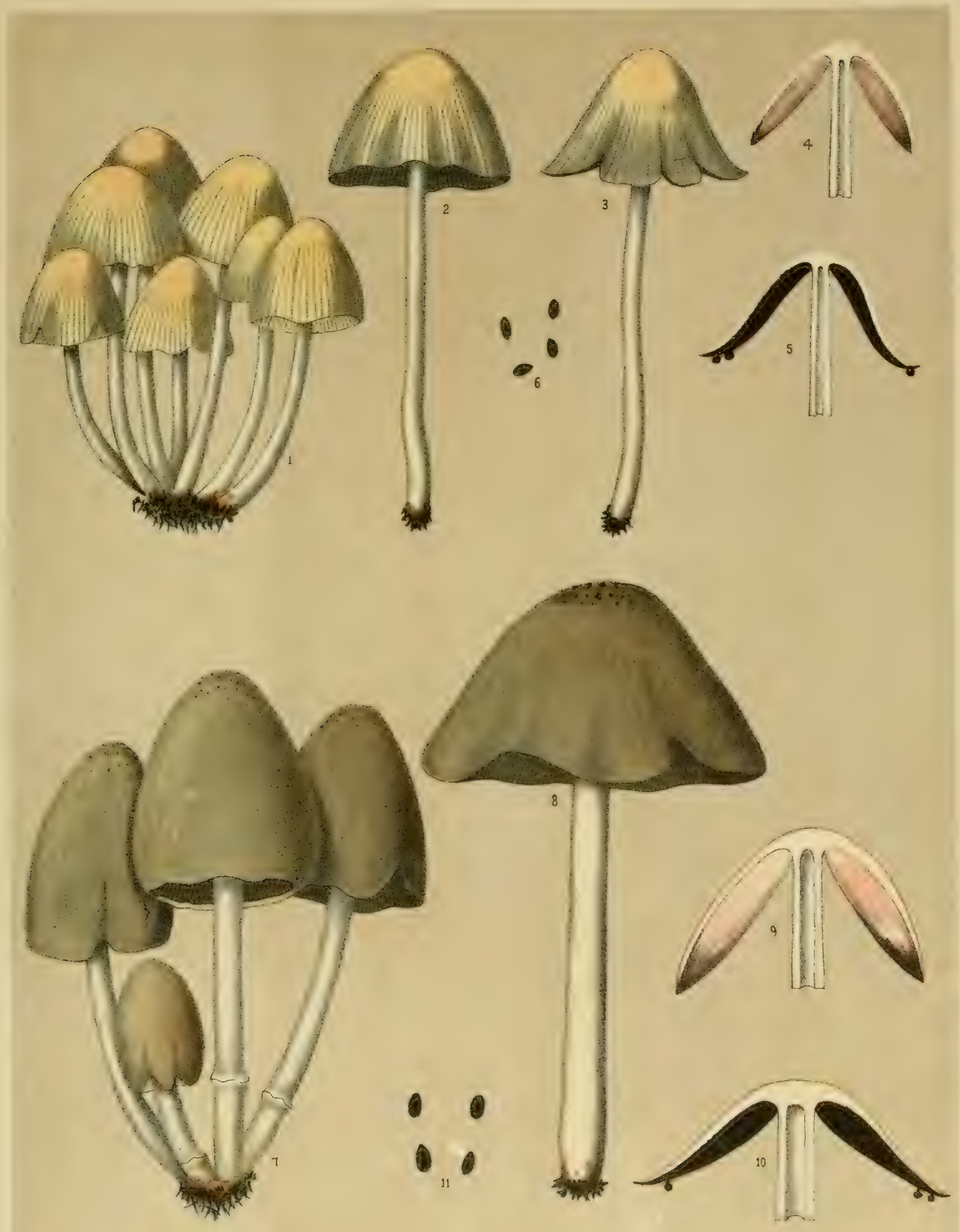

C H.PECK,DEL 



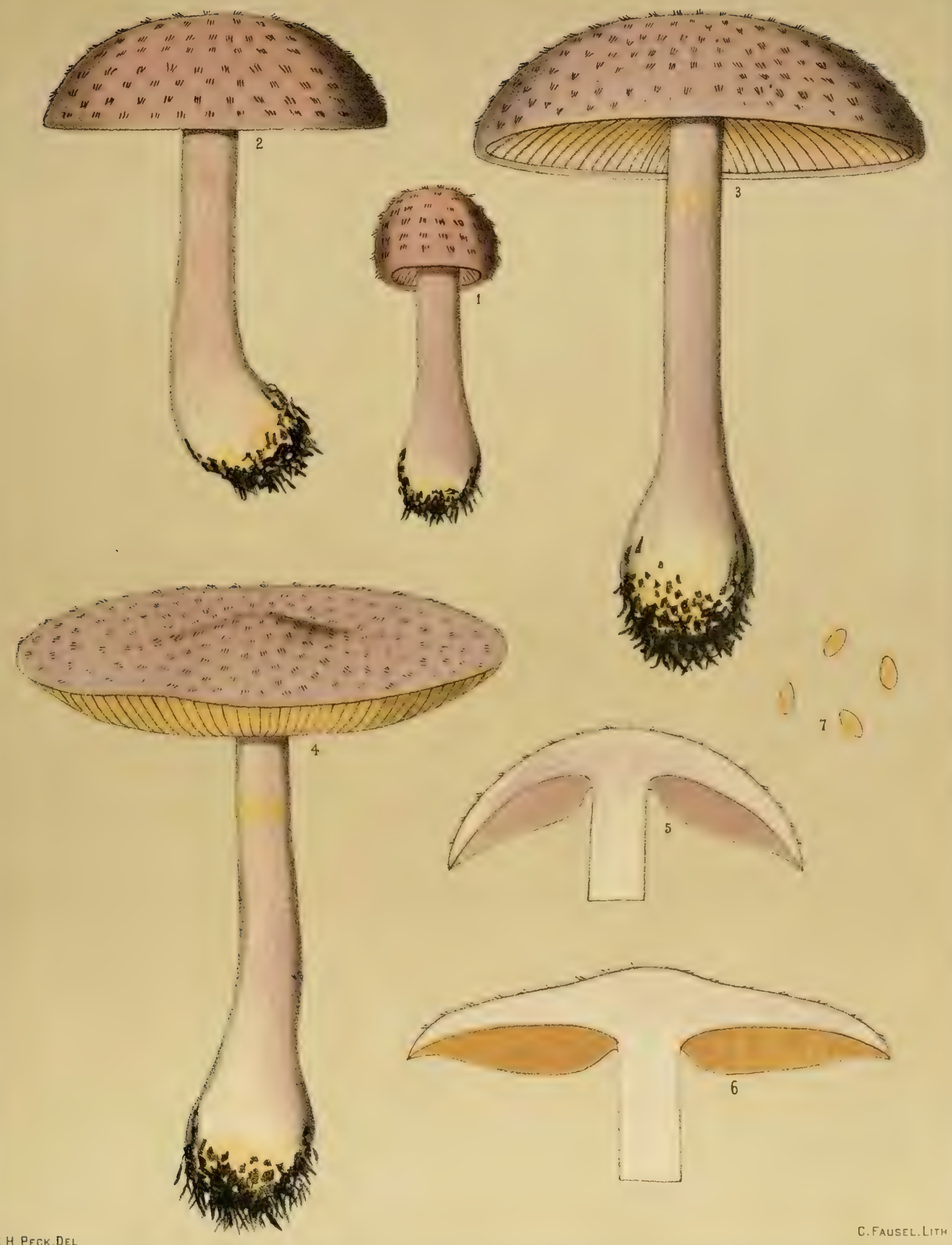





\section{EDIBLE FUNGI.}
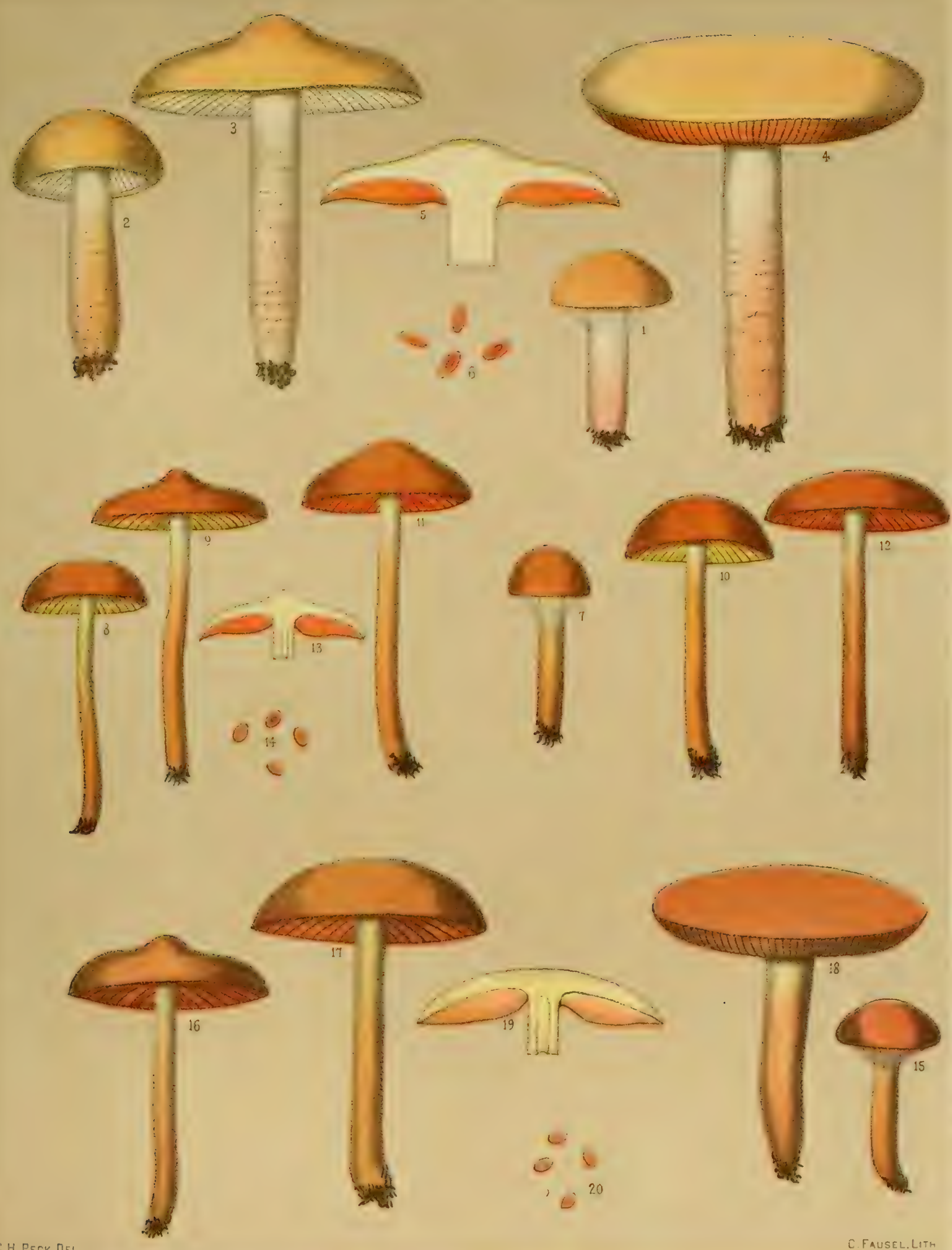

EDIBLE FUNGI.
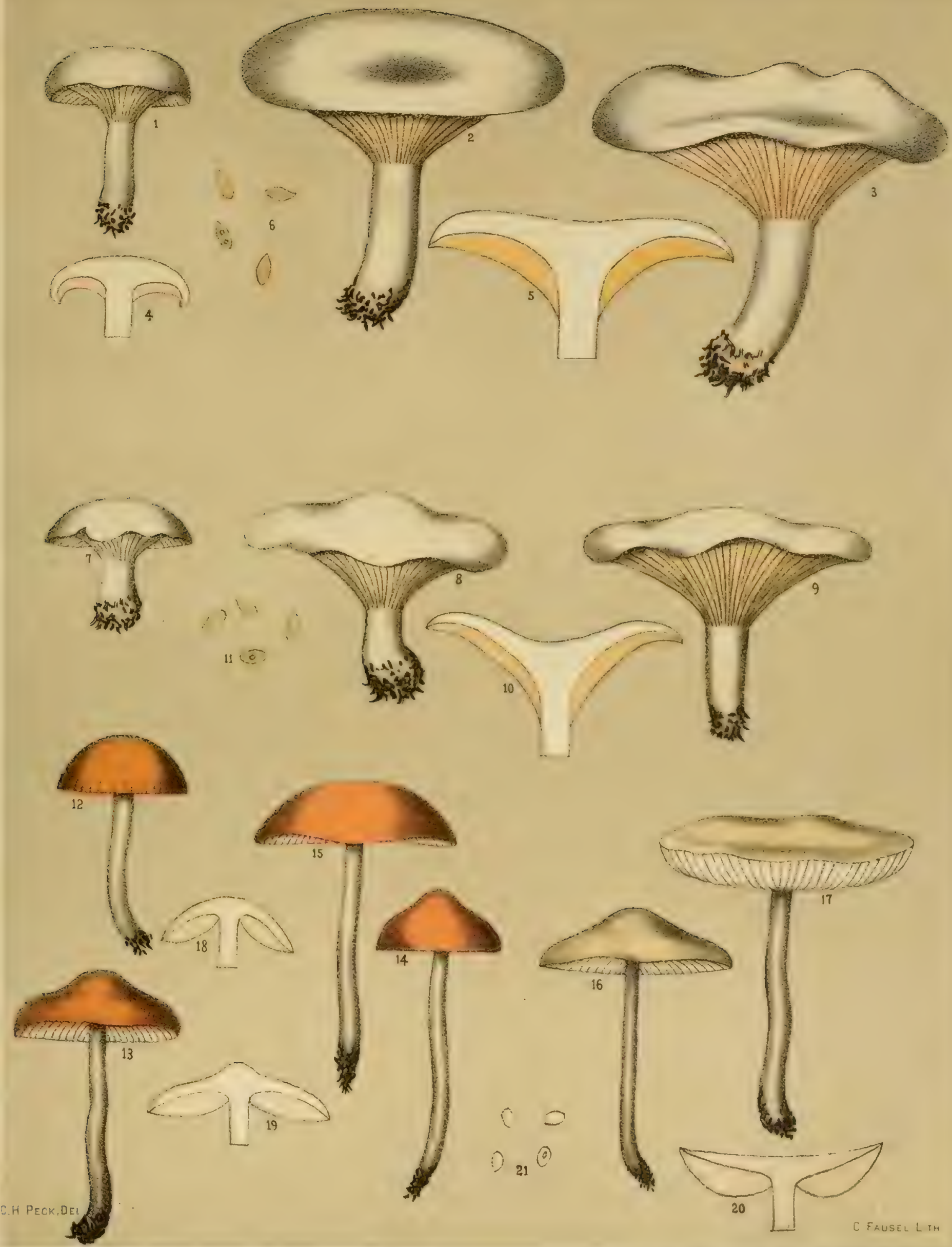

Fios. I 10 6 CLITOPILUS PRUNULUS scop 



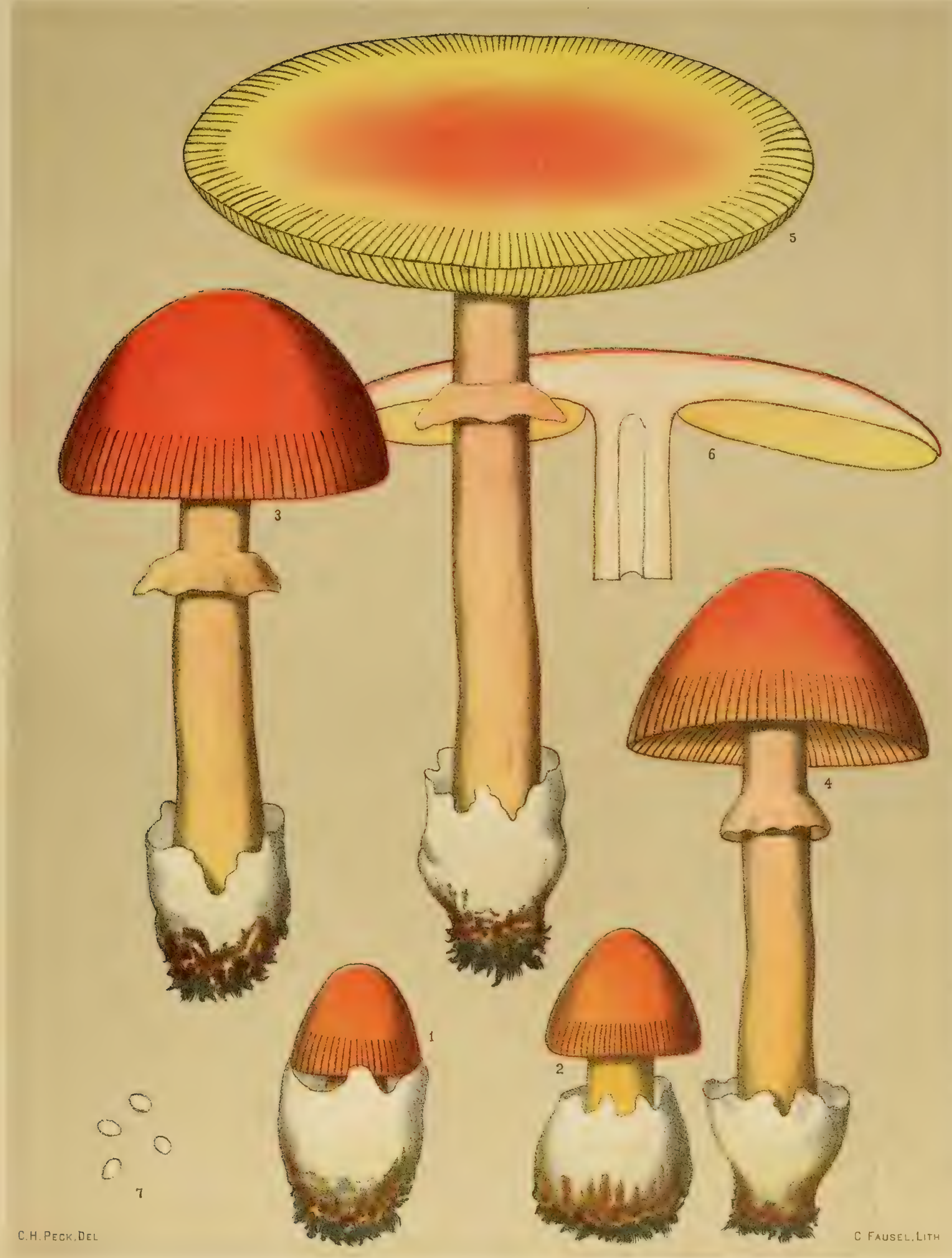





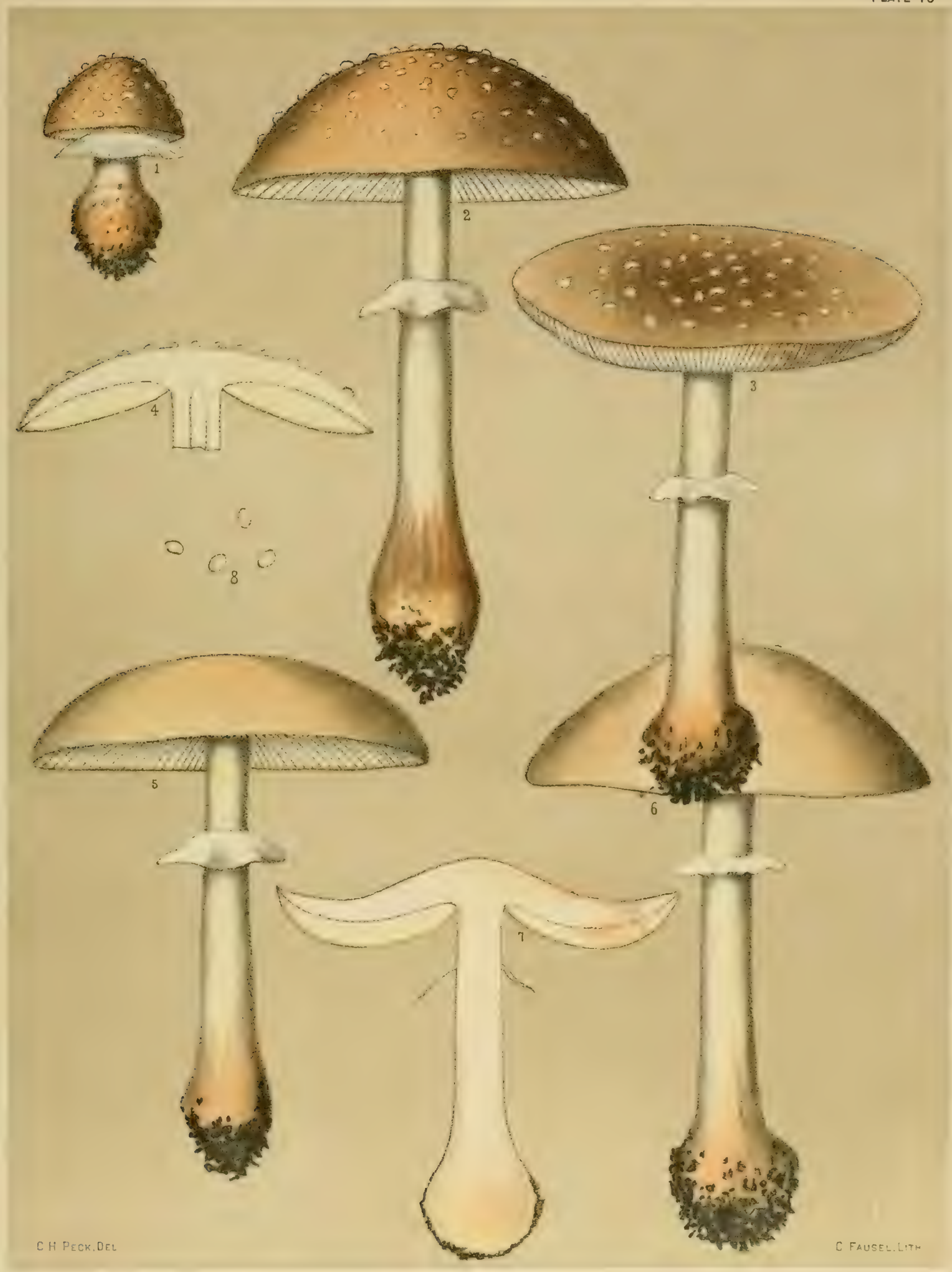





\section{EDIBLE FUNGI.}
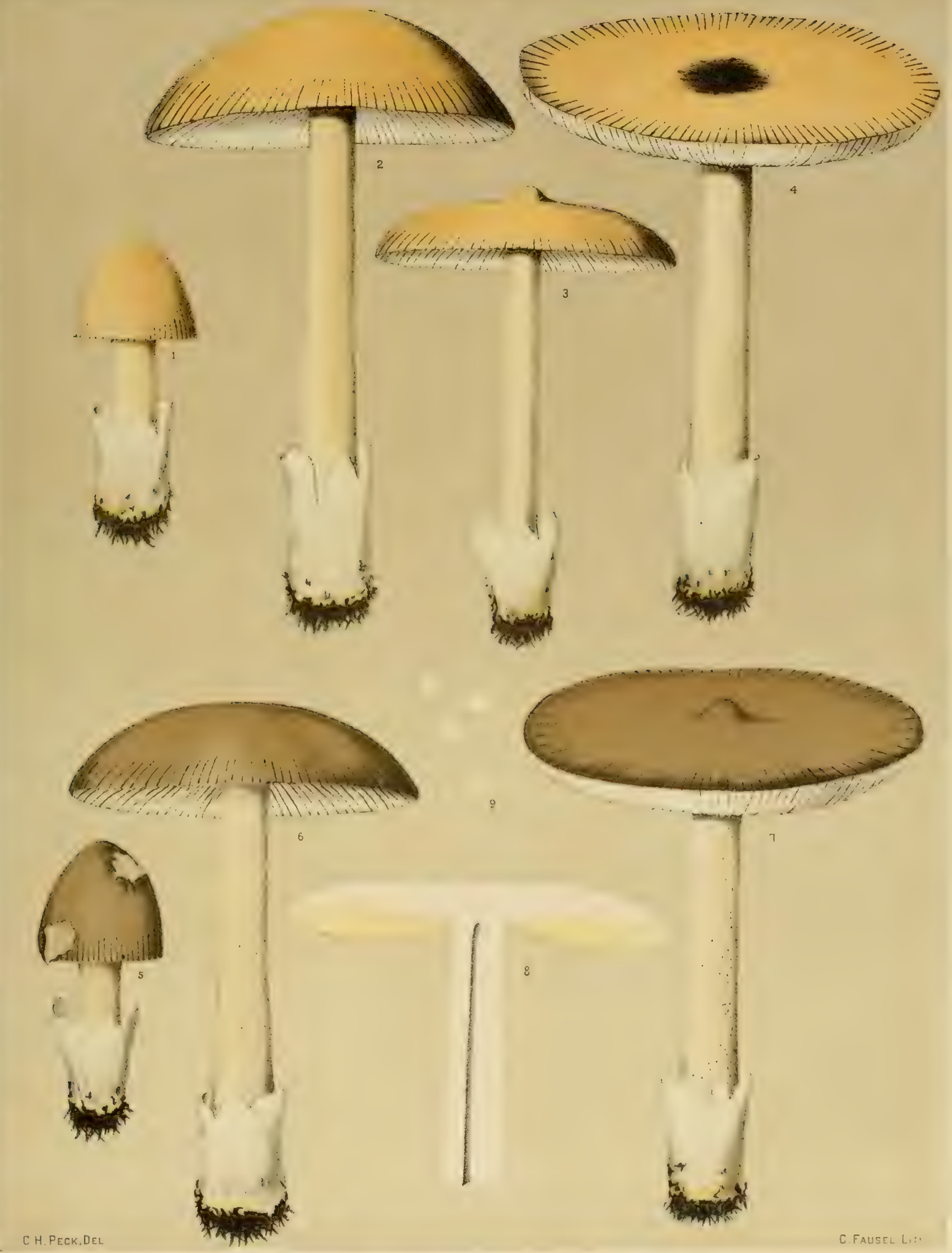



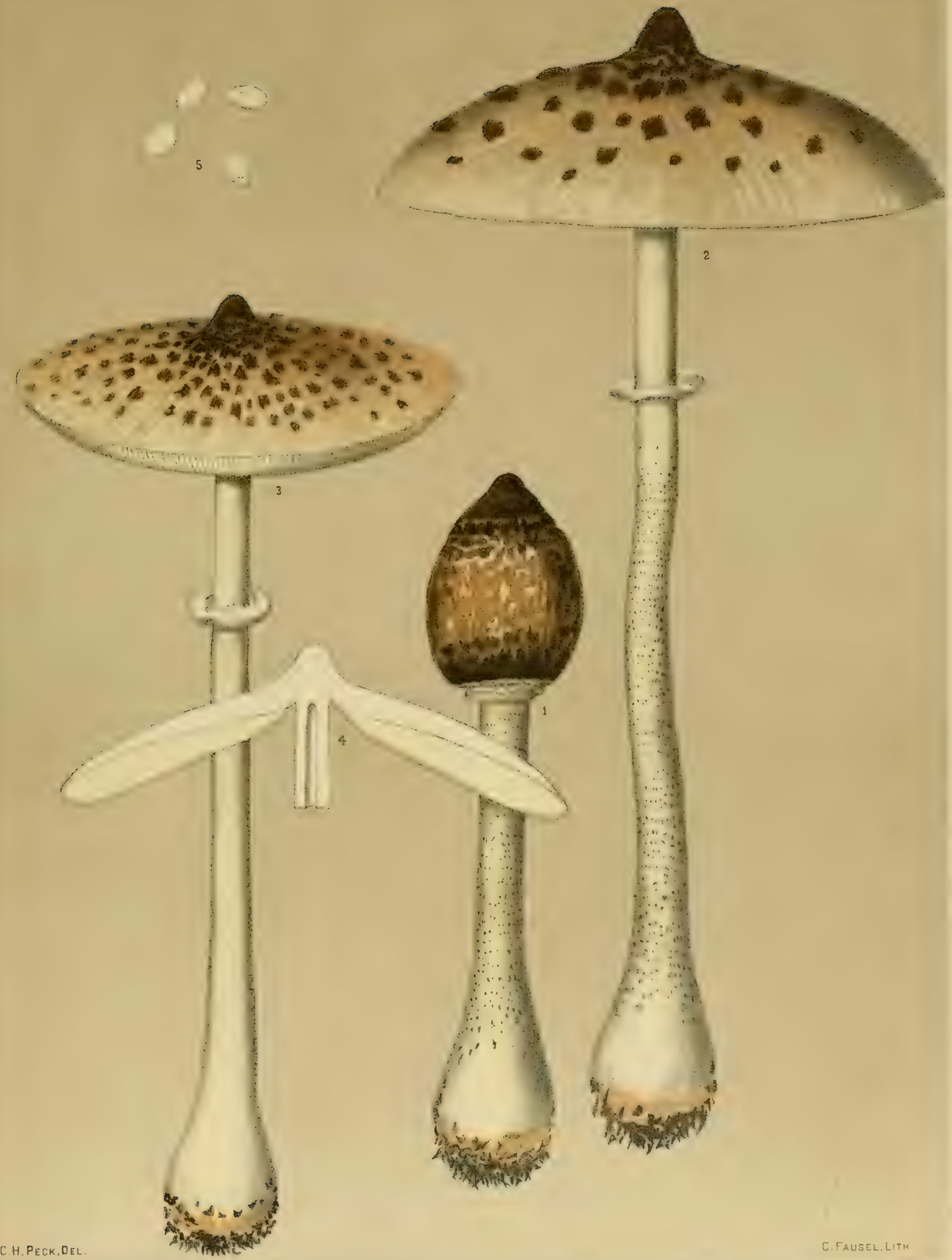





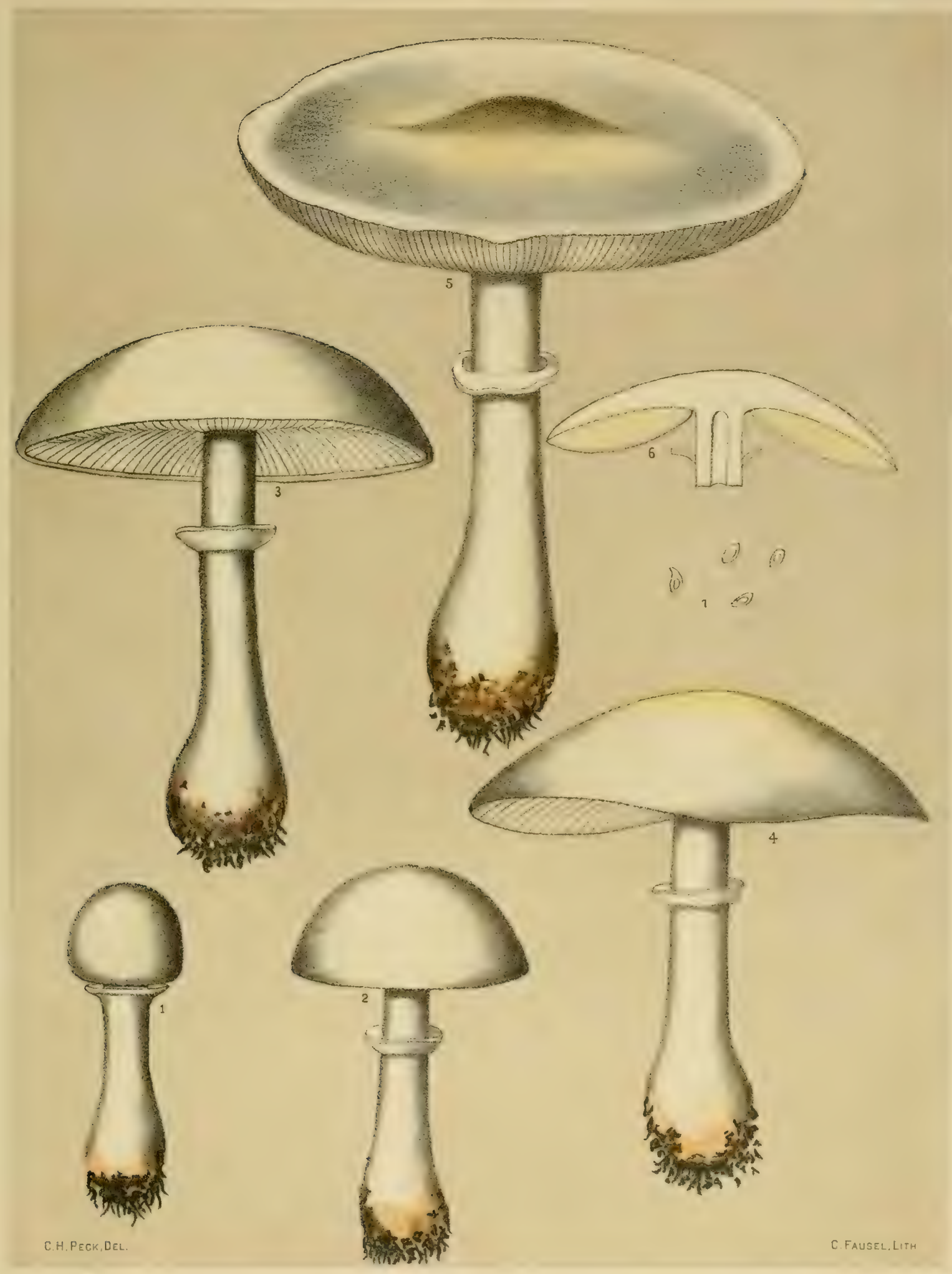





\section{EDIBLE FUNGI.}

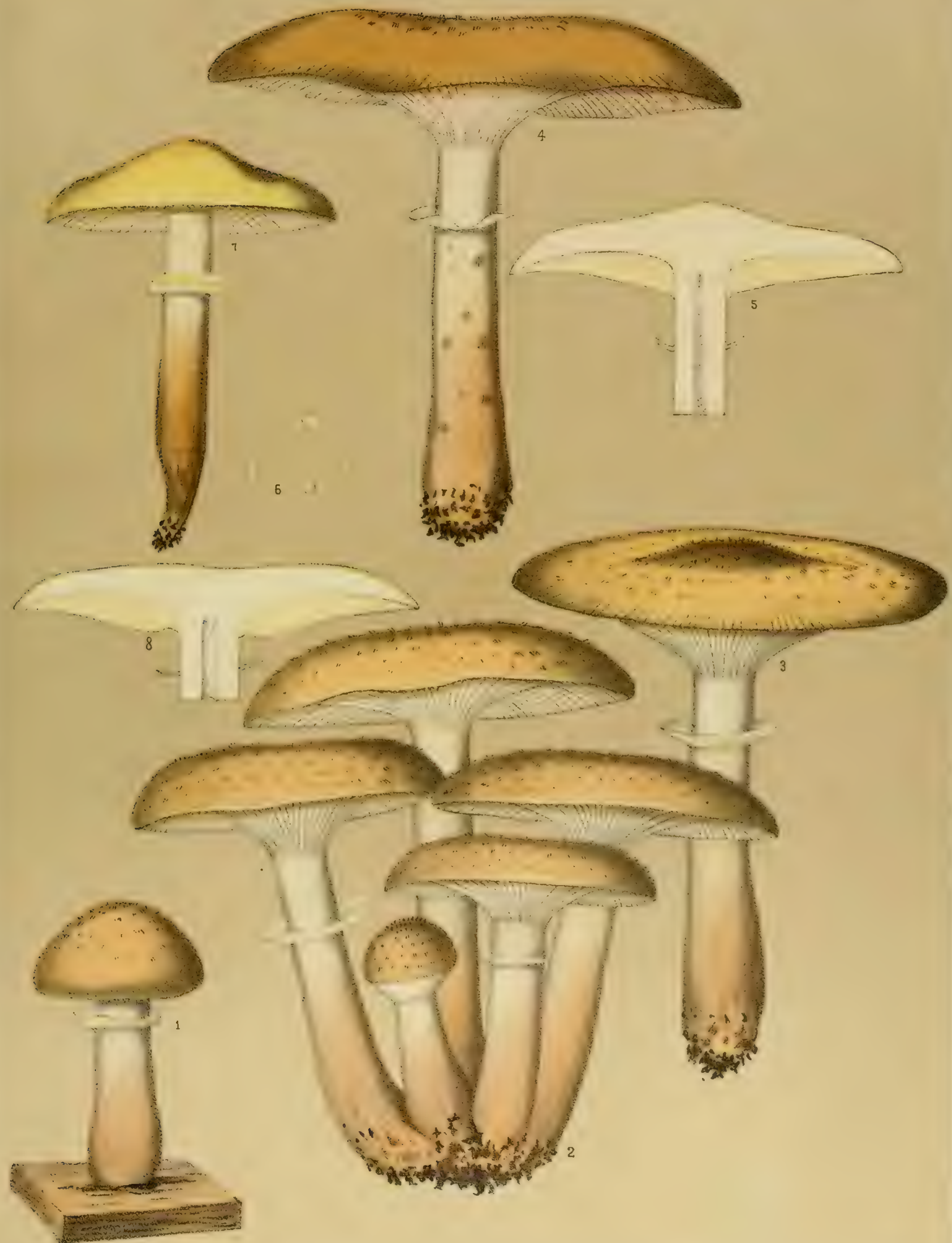





\section{EDIBLE FUNGI.}

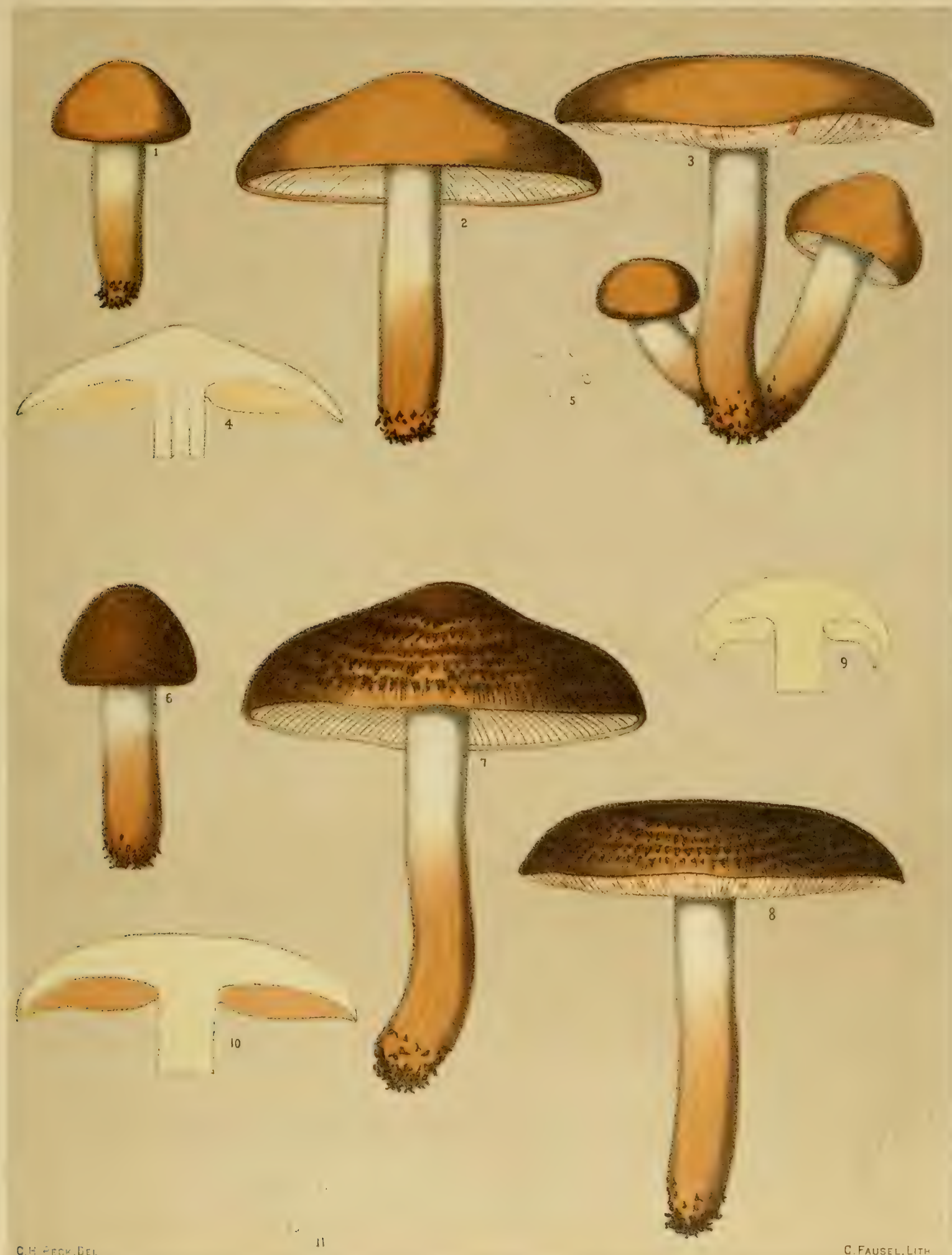





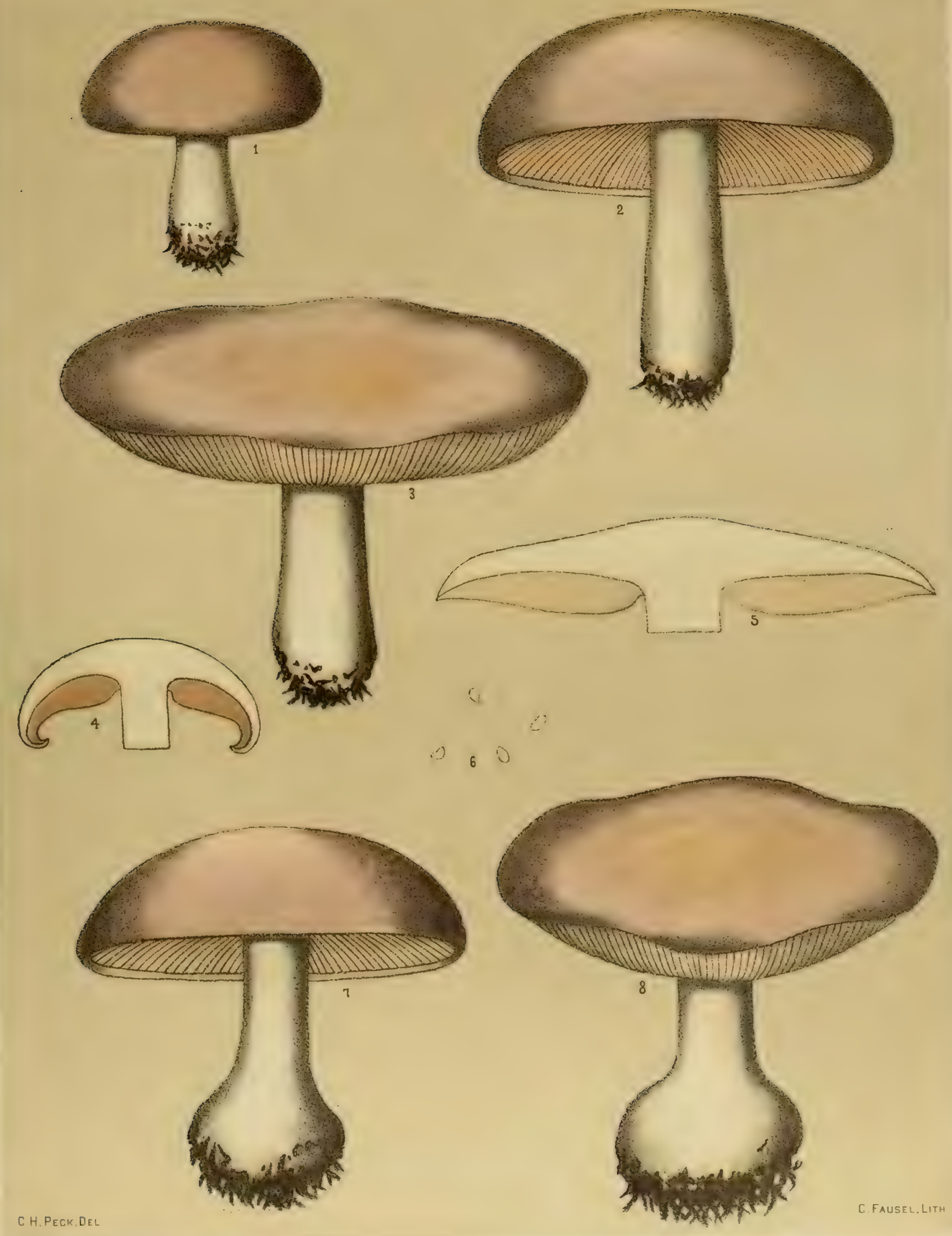





\section{EDIBLE FUNGI.}

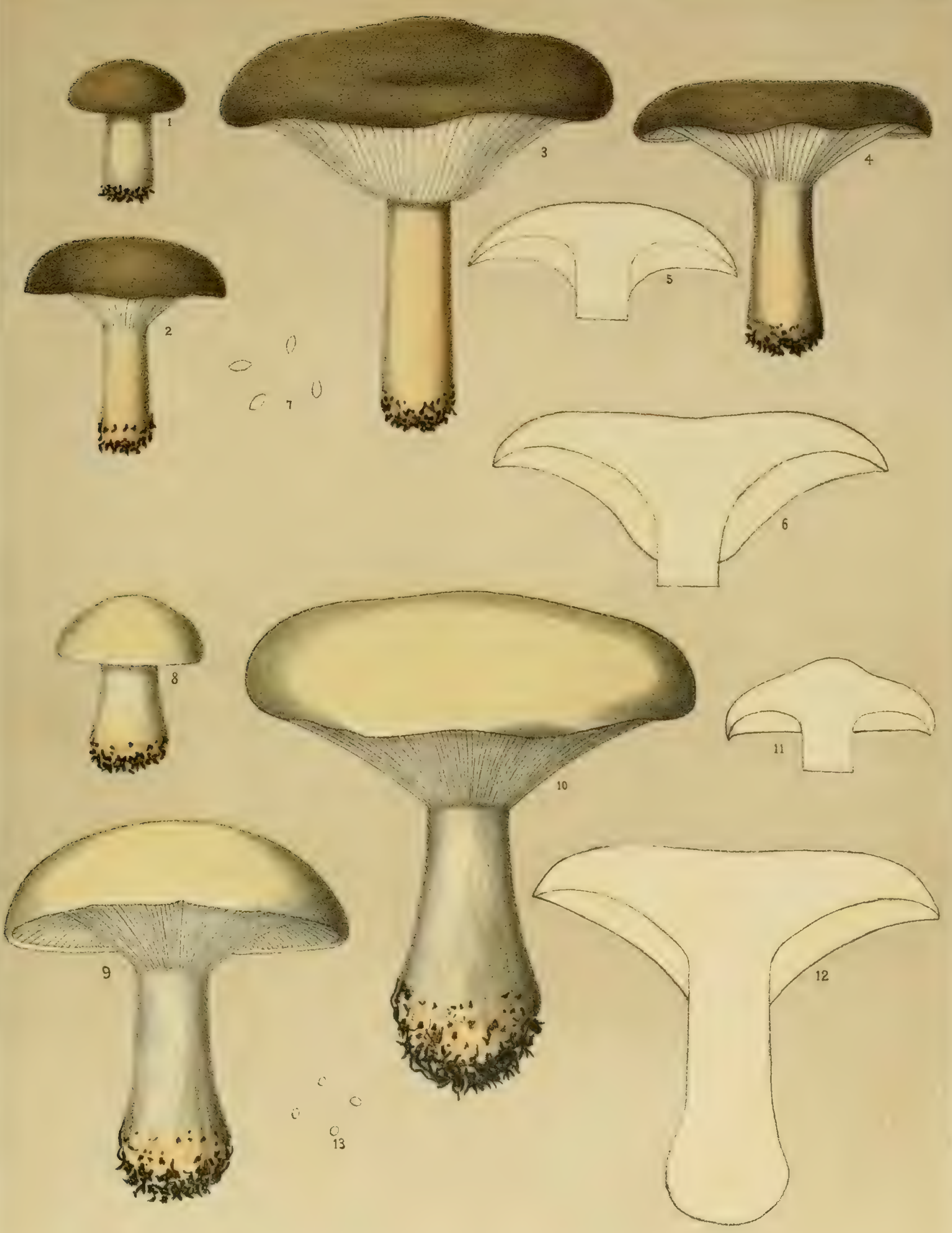





\section{EDIBLE FUNGI.}

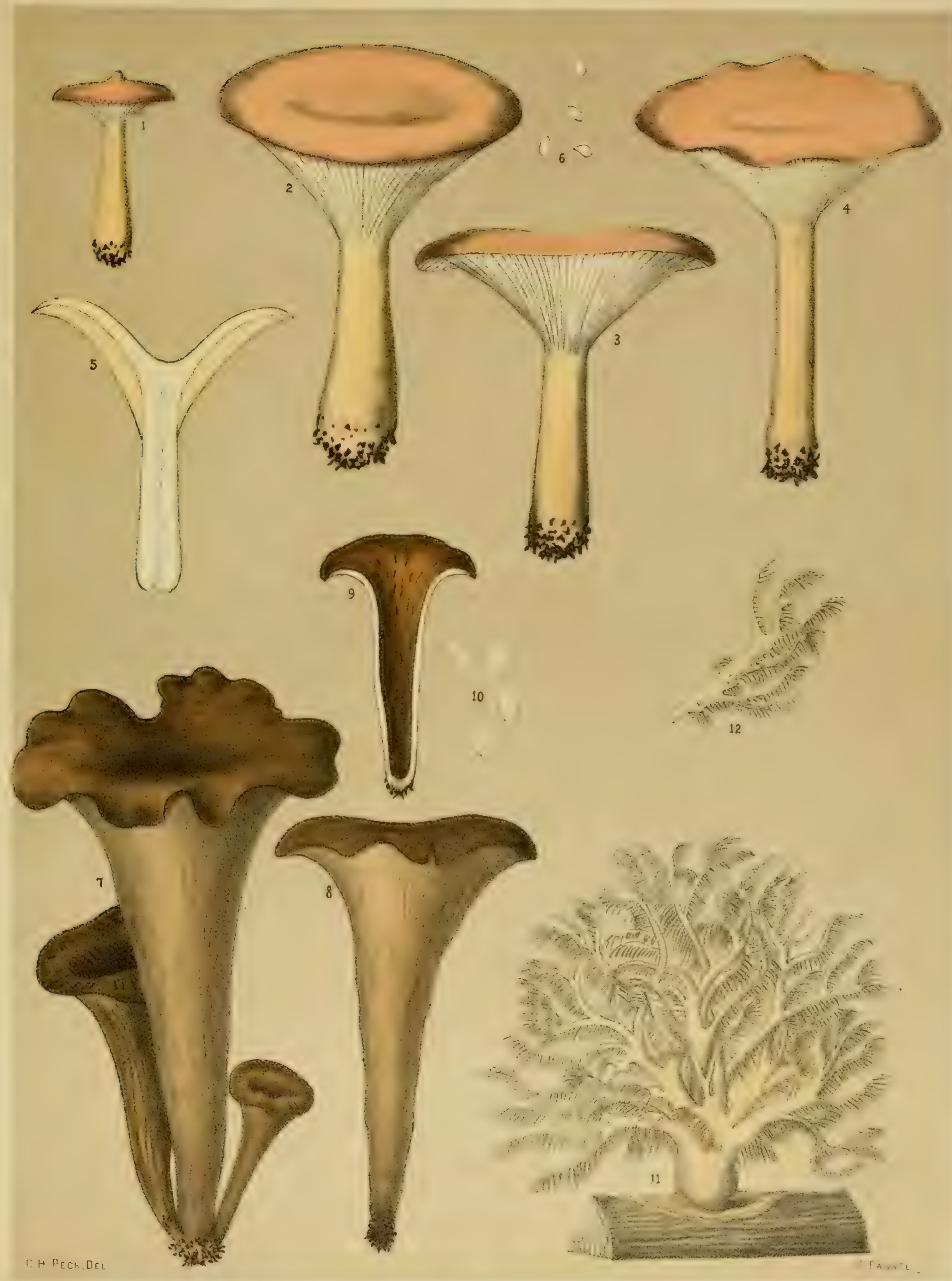





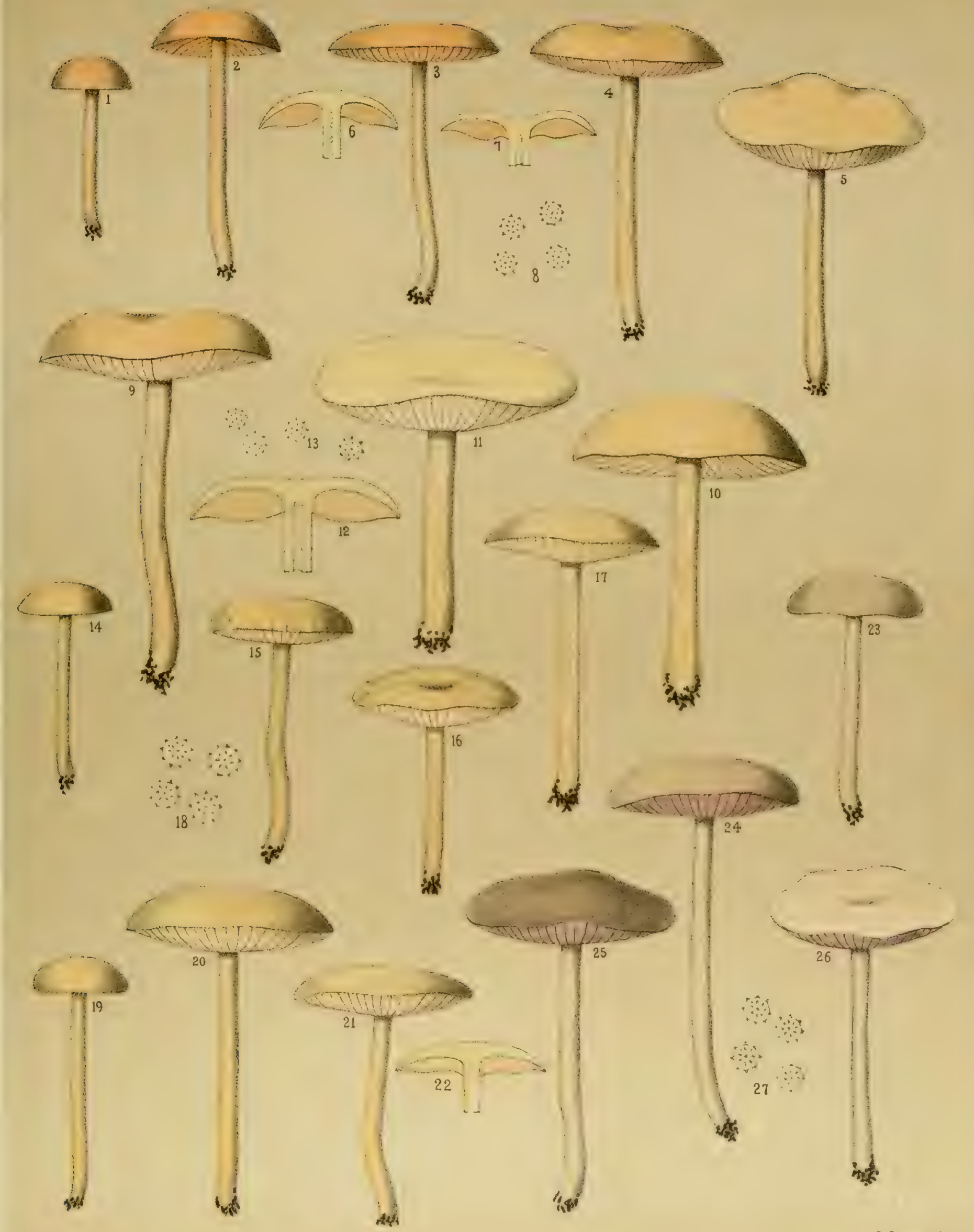




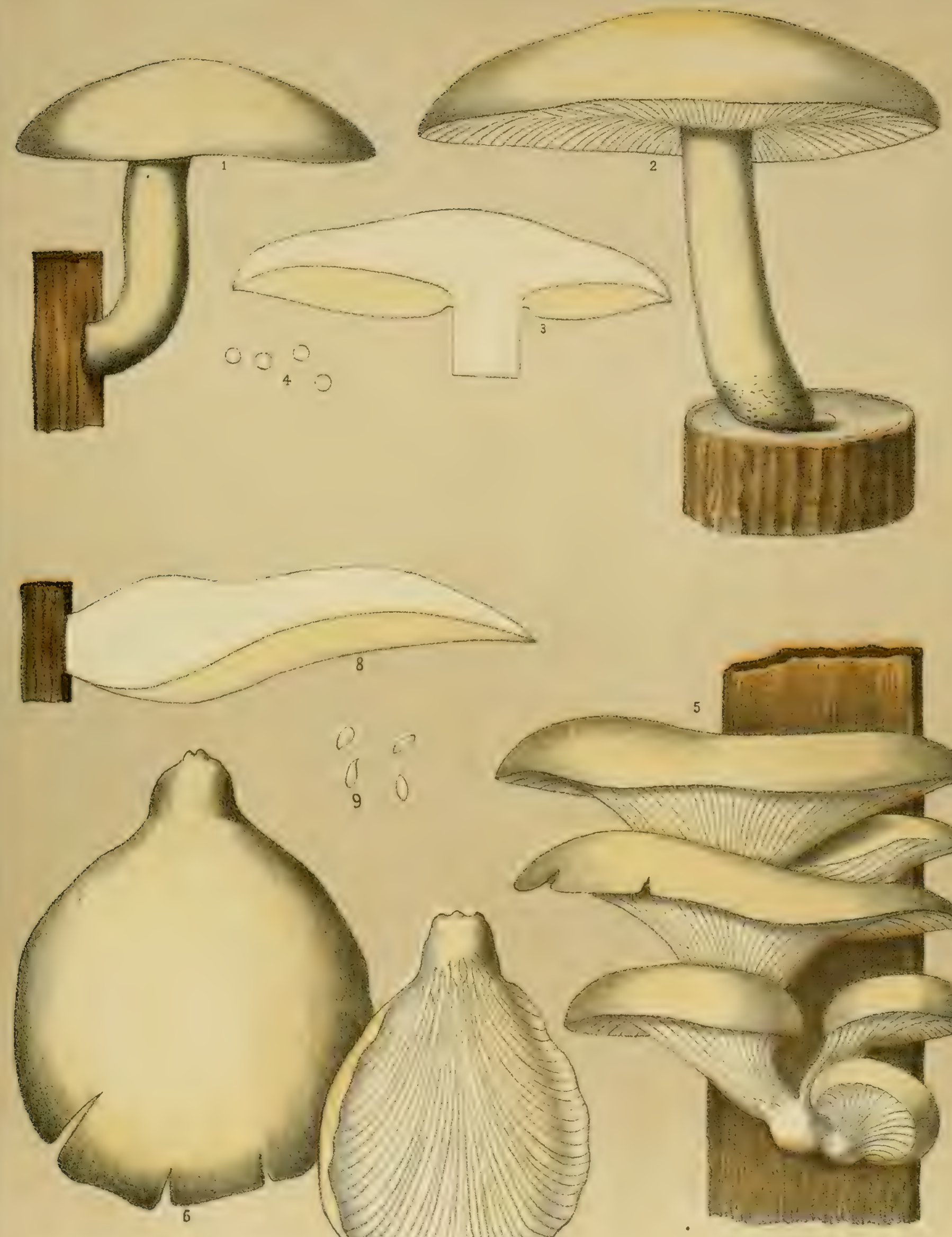

C. H PECK DEL

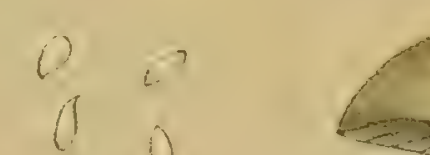

5

90
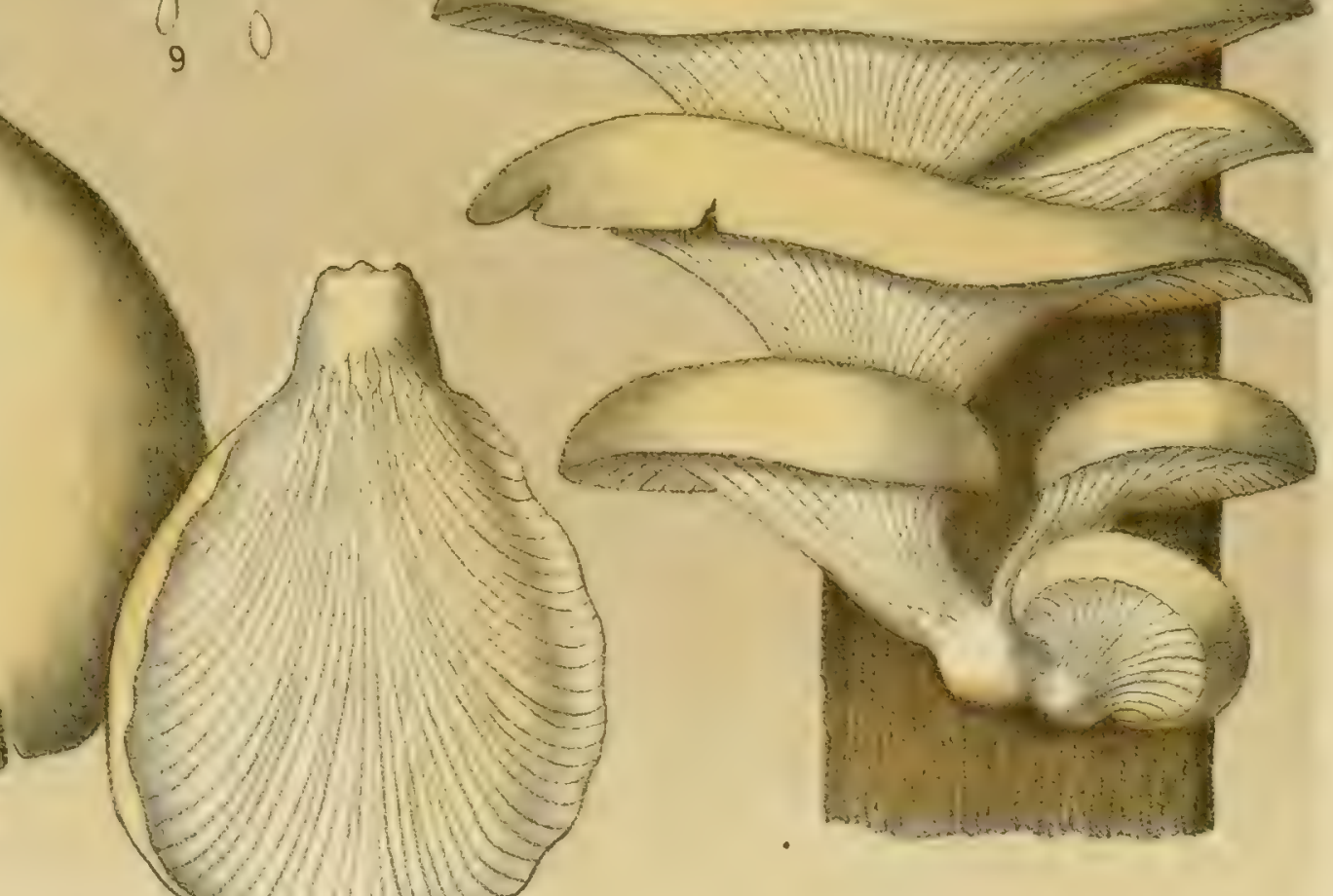



\section{EDIBLE FUNGI.}

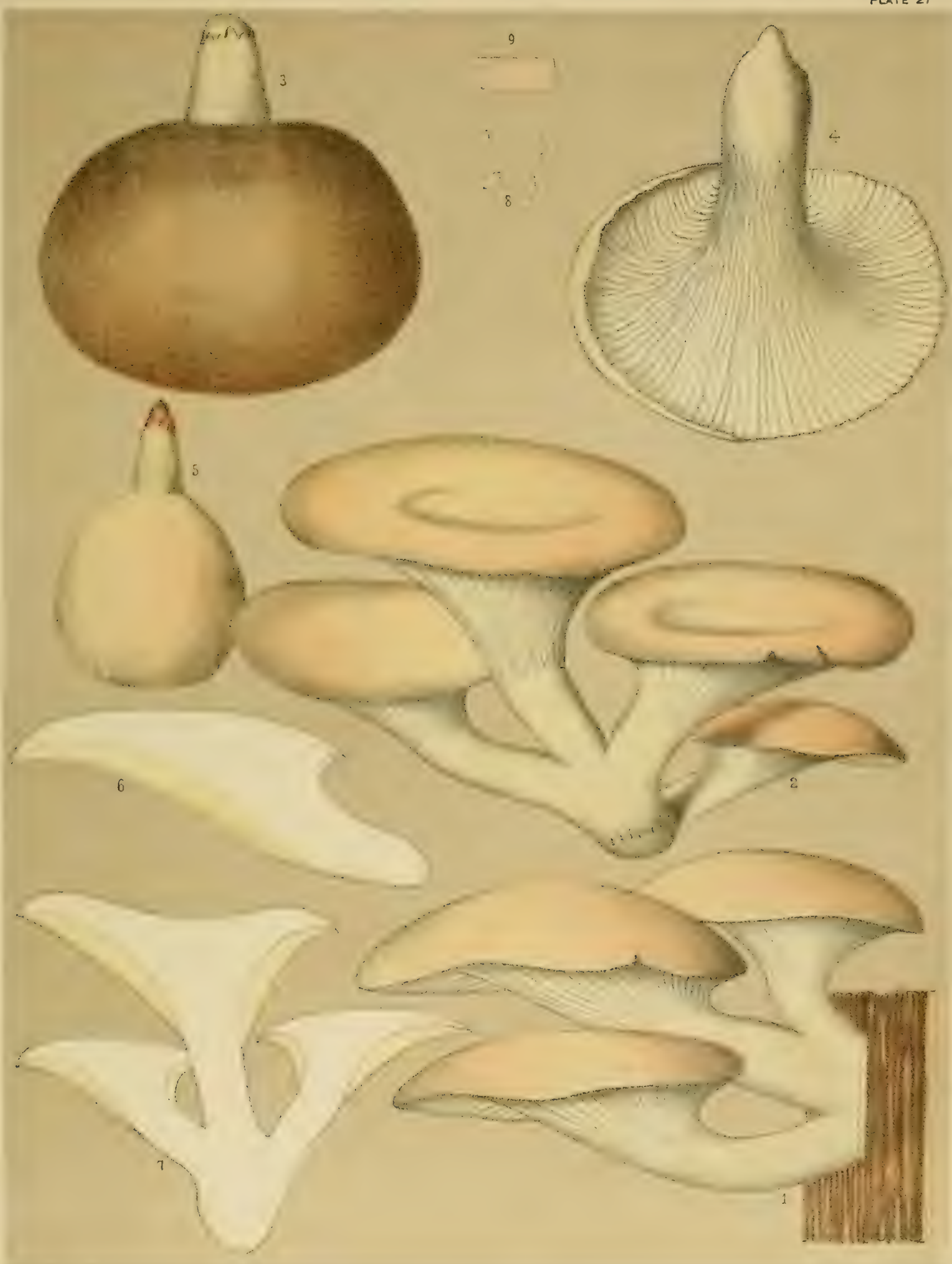





\section{EDIBLE FUNGI.}
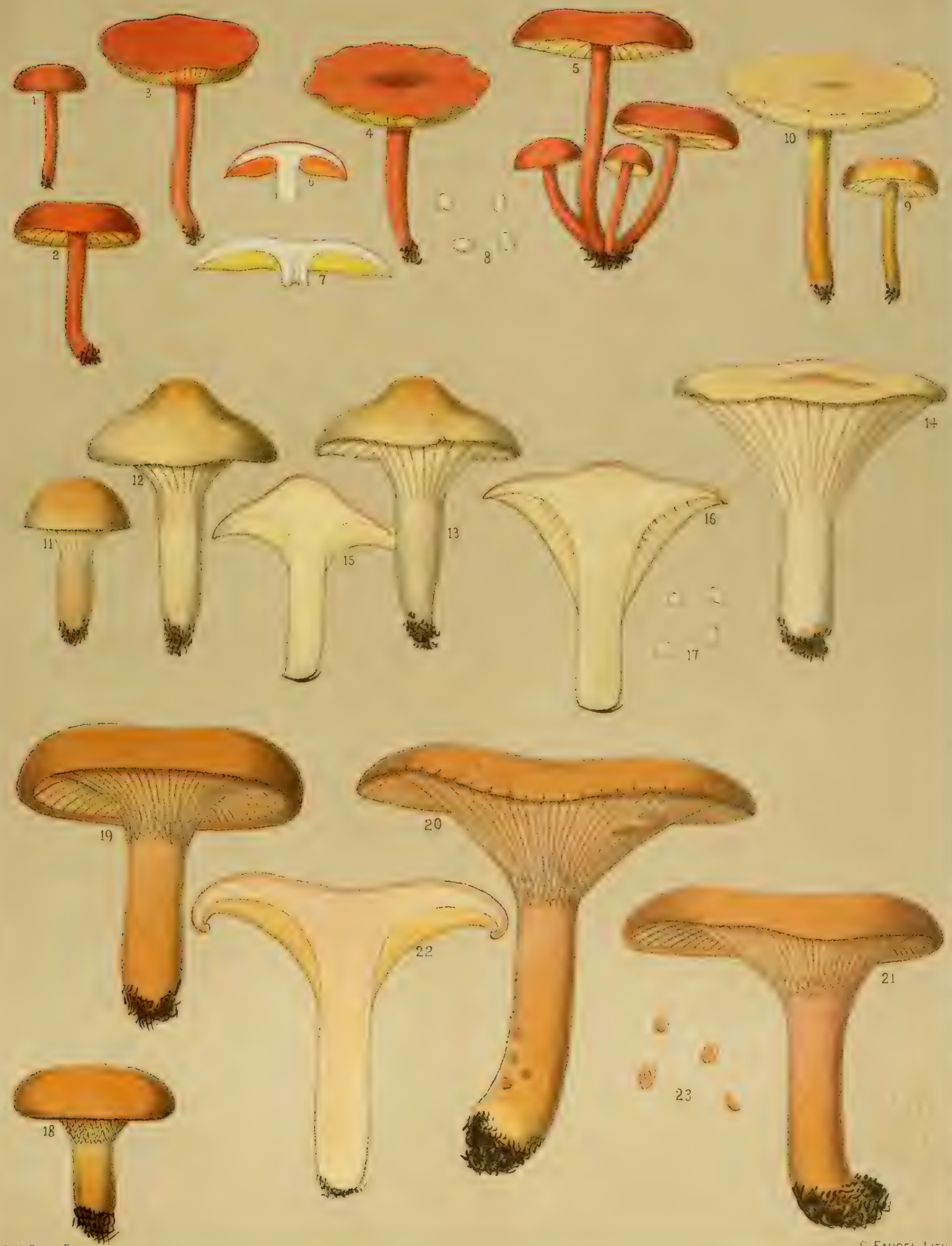



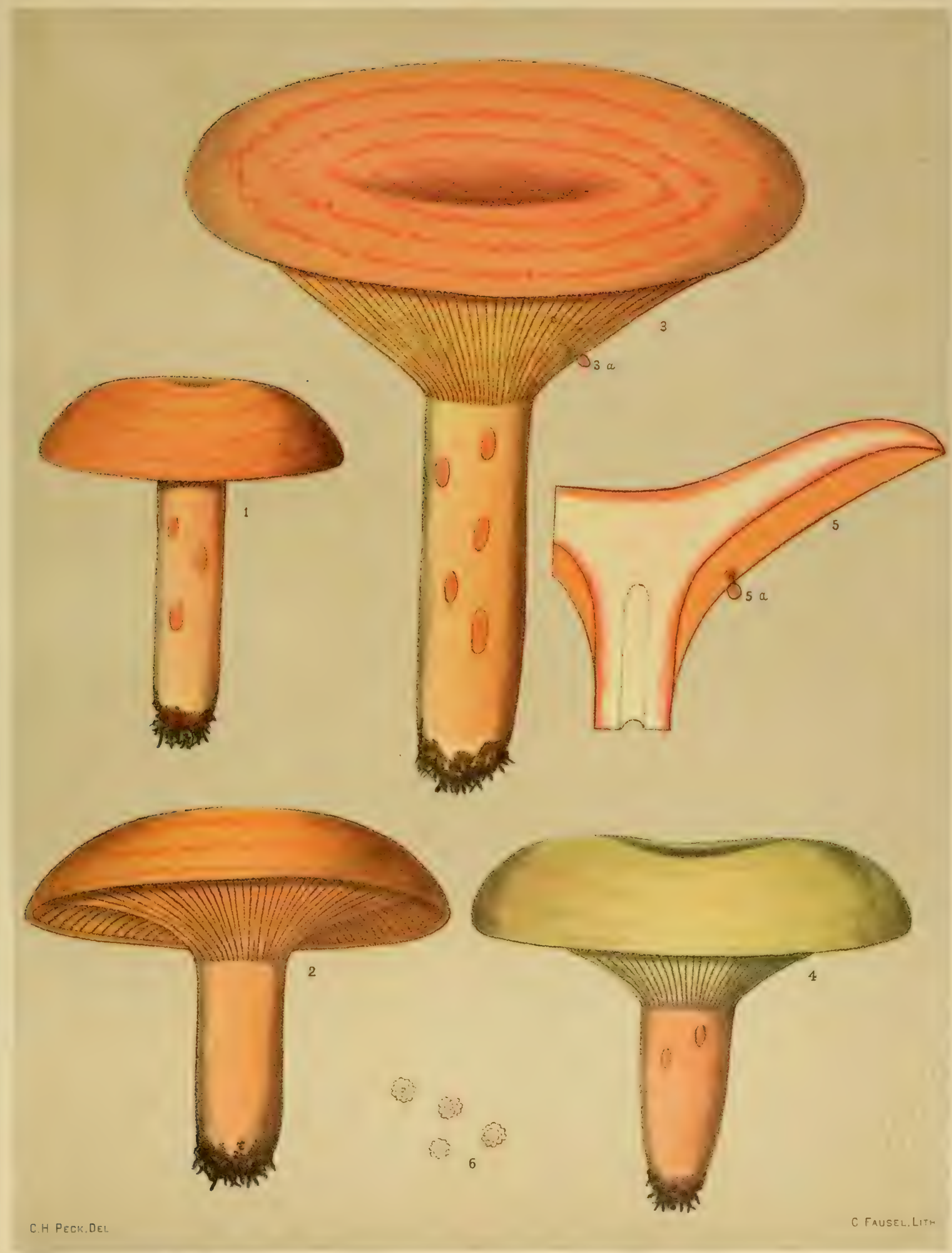





\section{EDIBLE FUNGI.}

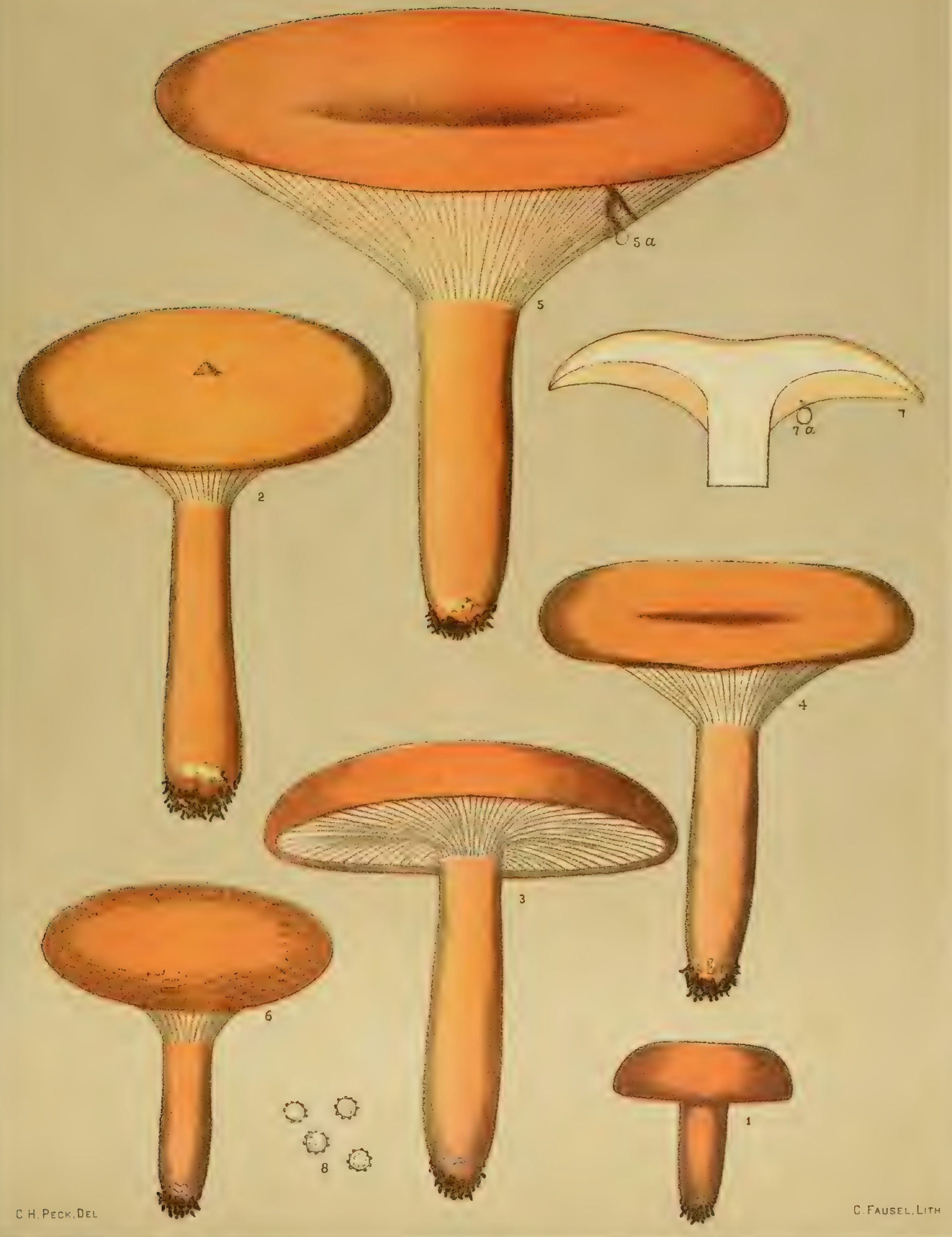





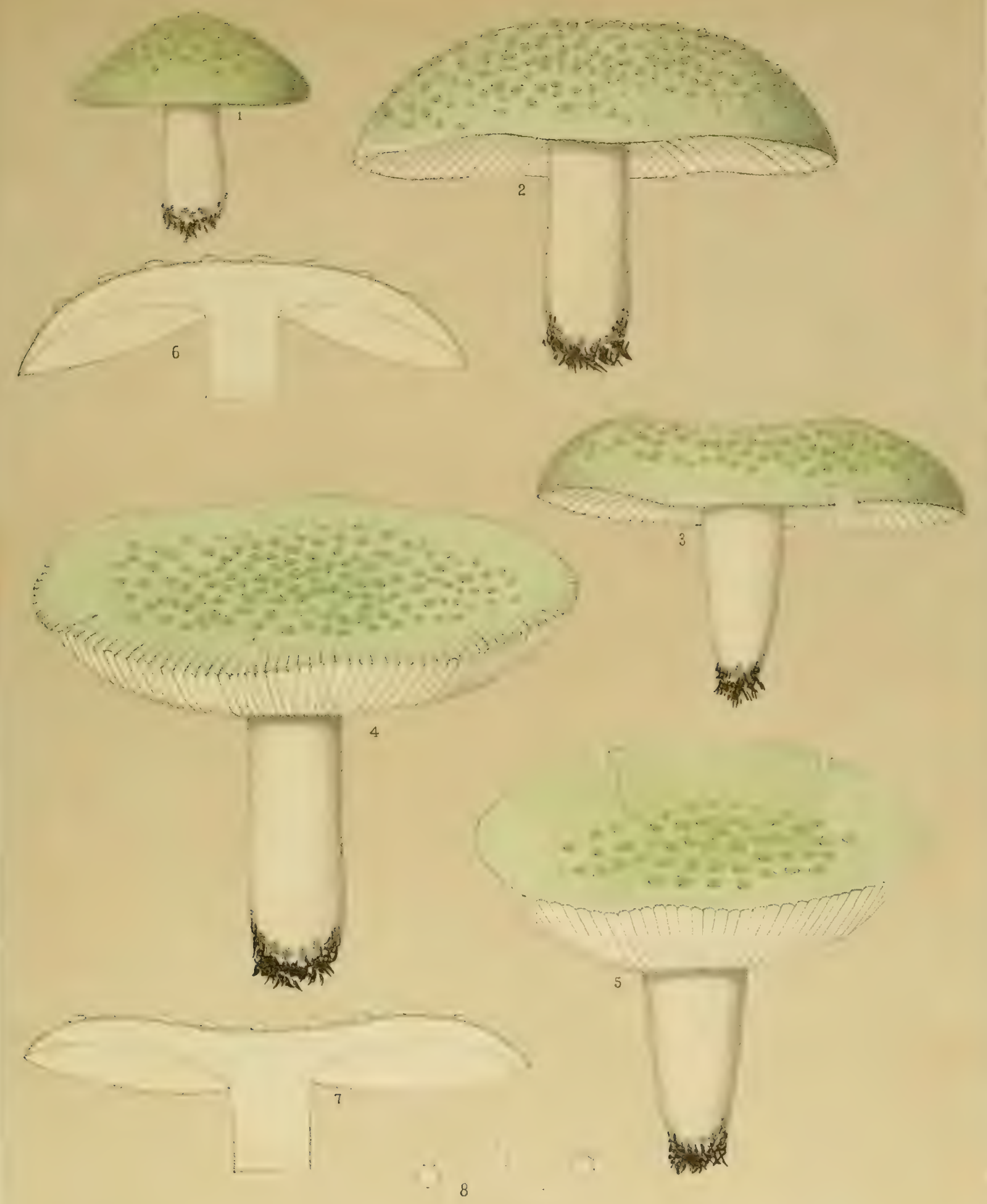





\section{EDIBLE FUNGI.}
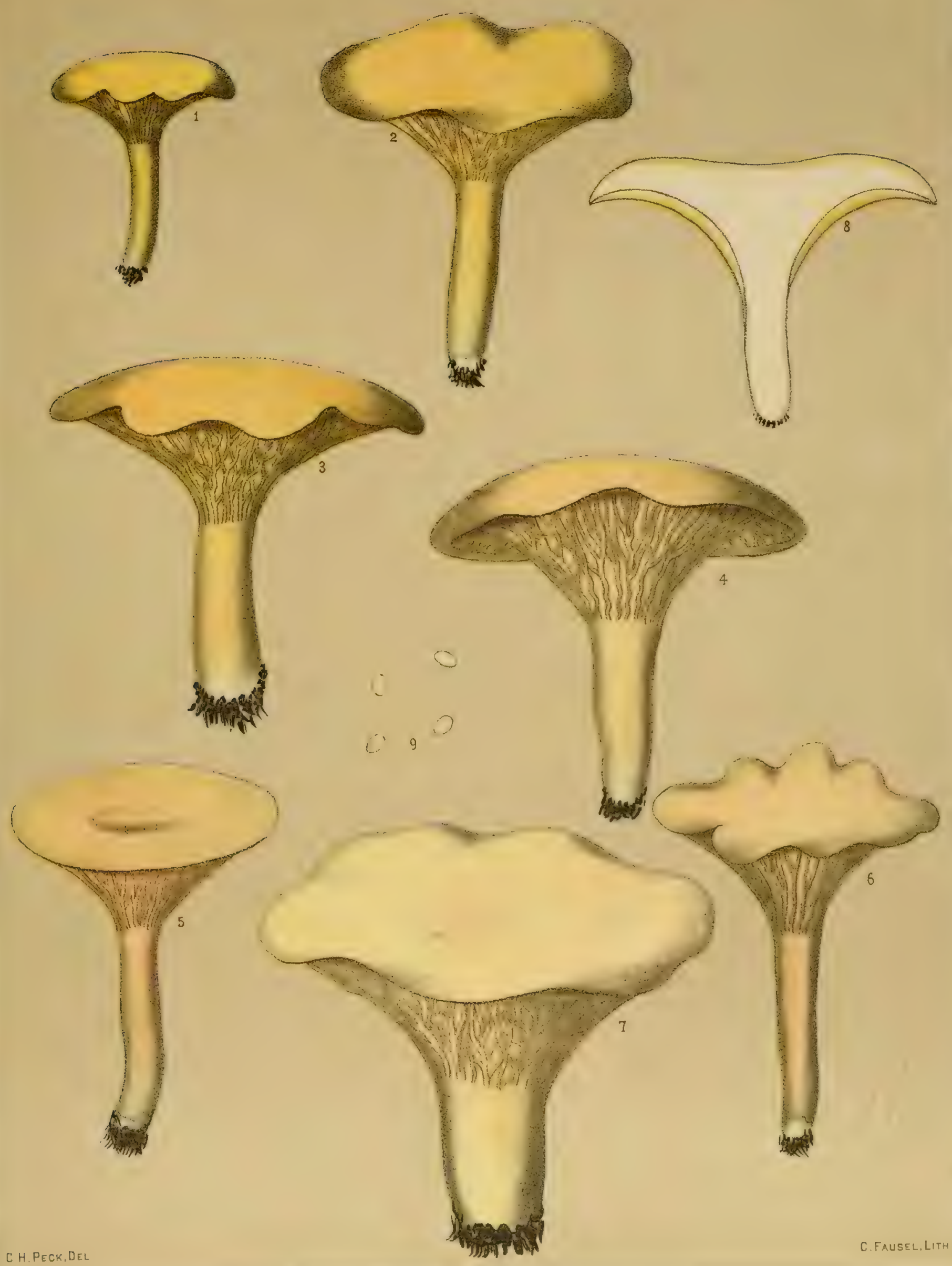


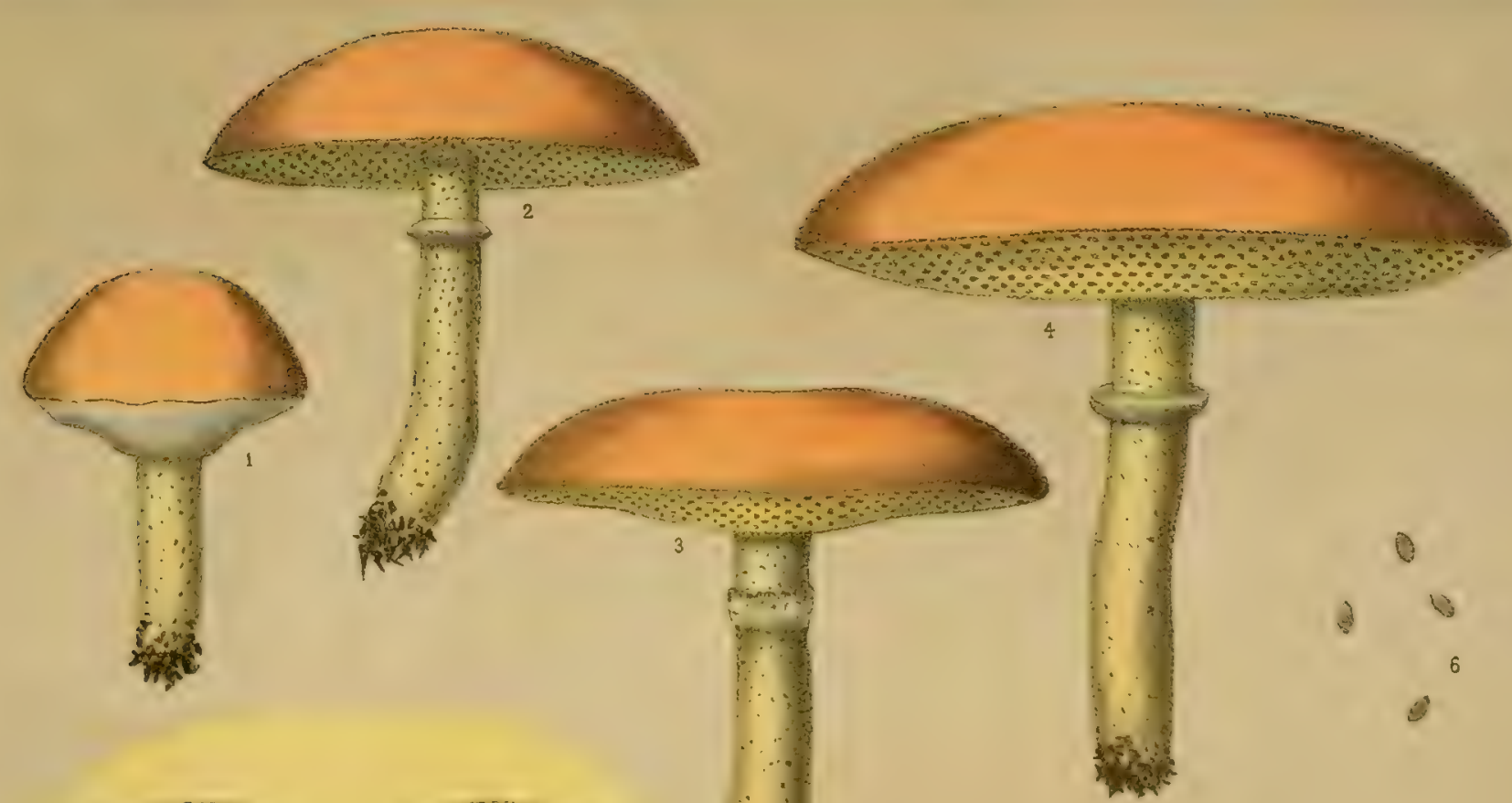

0

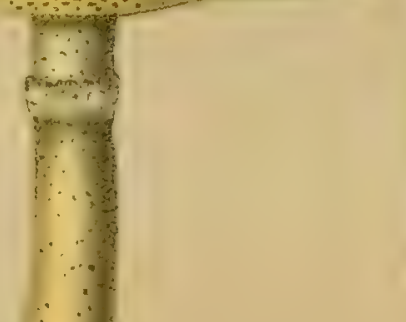

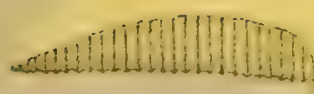
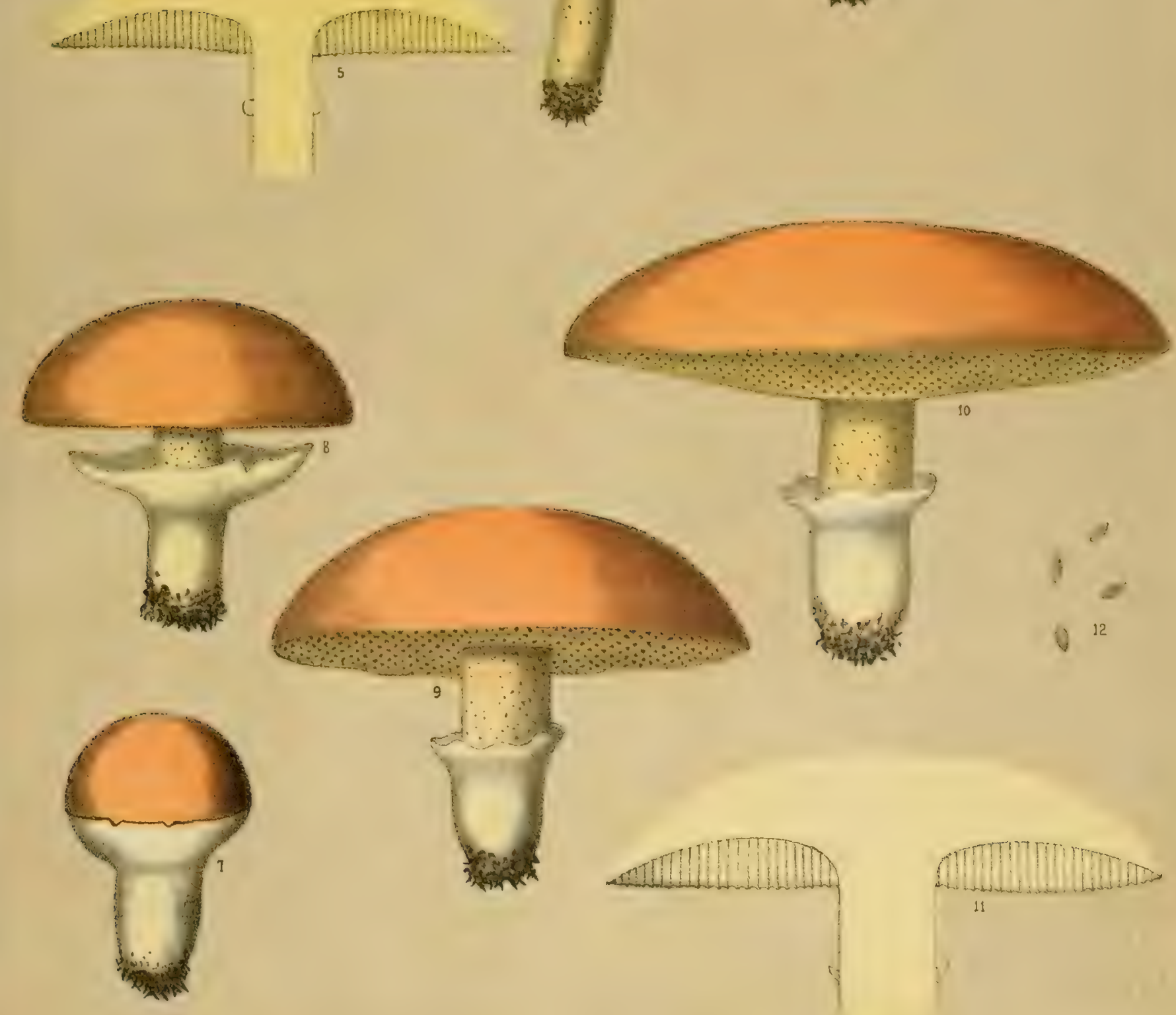

11

C.H.PECK.DEL

C. FAUSEL, LITH. 



\section{EDIBLE FUNGI.}
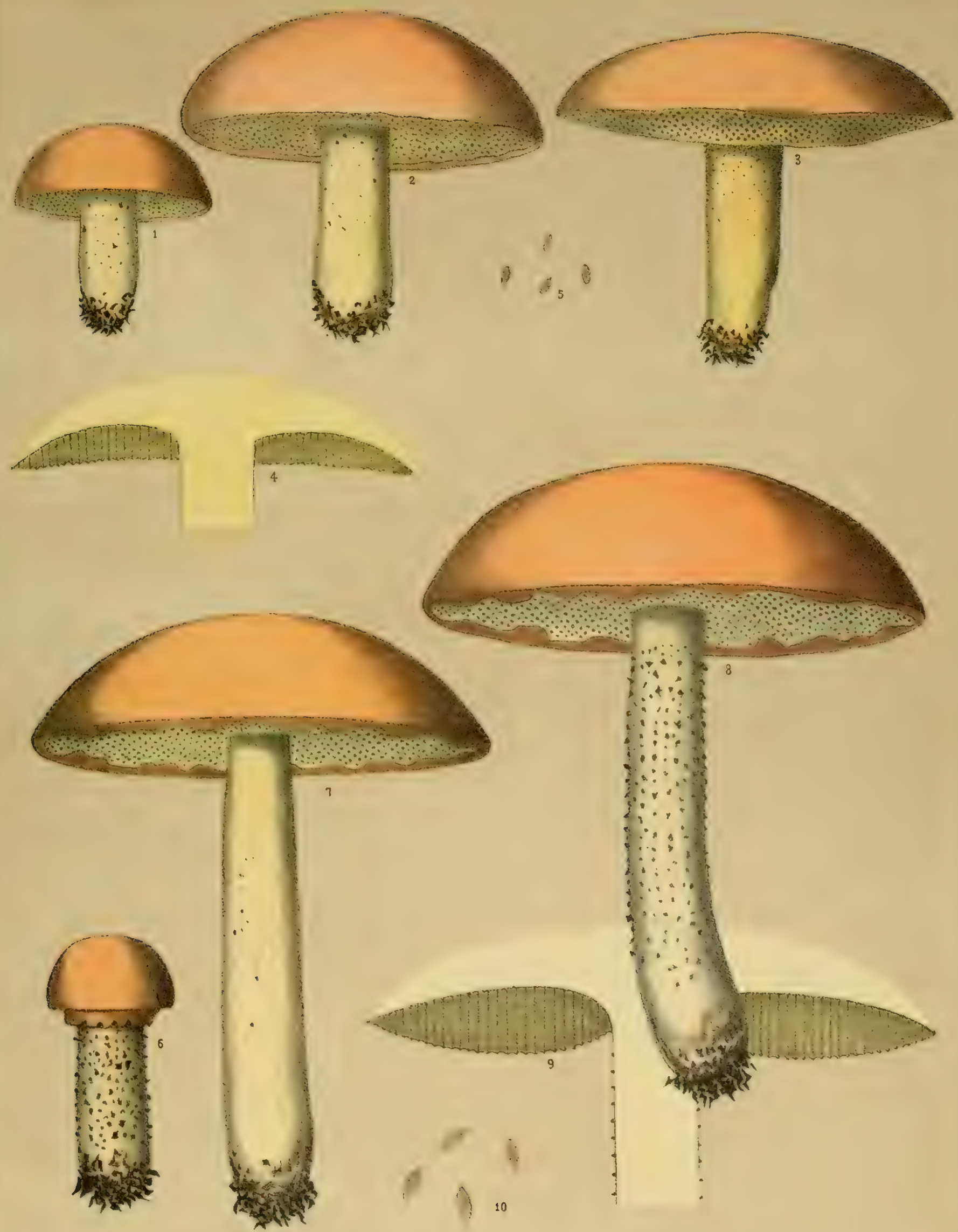



\section{EDIBLE FUNGI.}

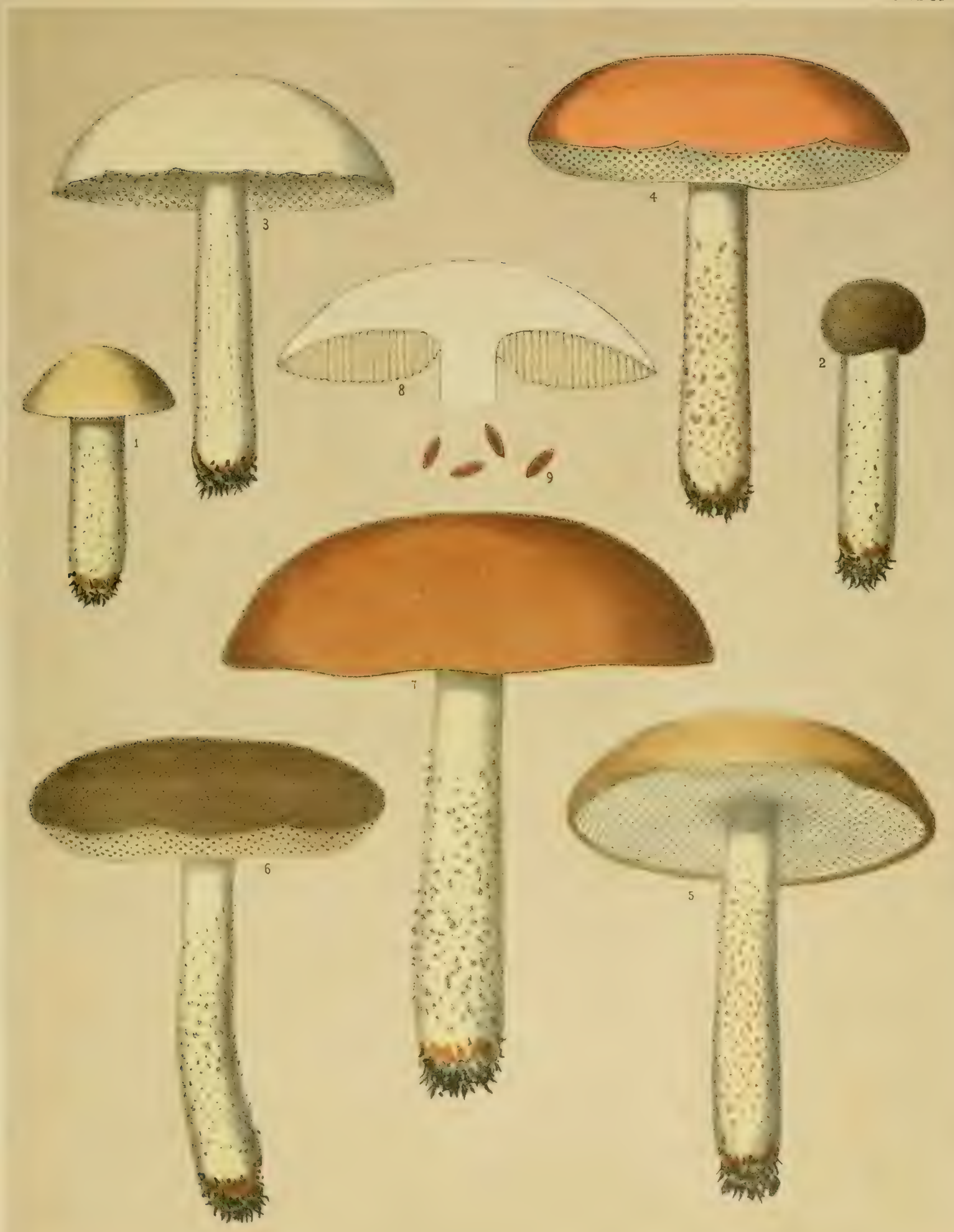





\section{EDIBLE FUNGI.}

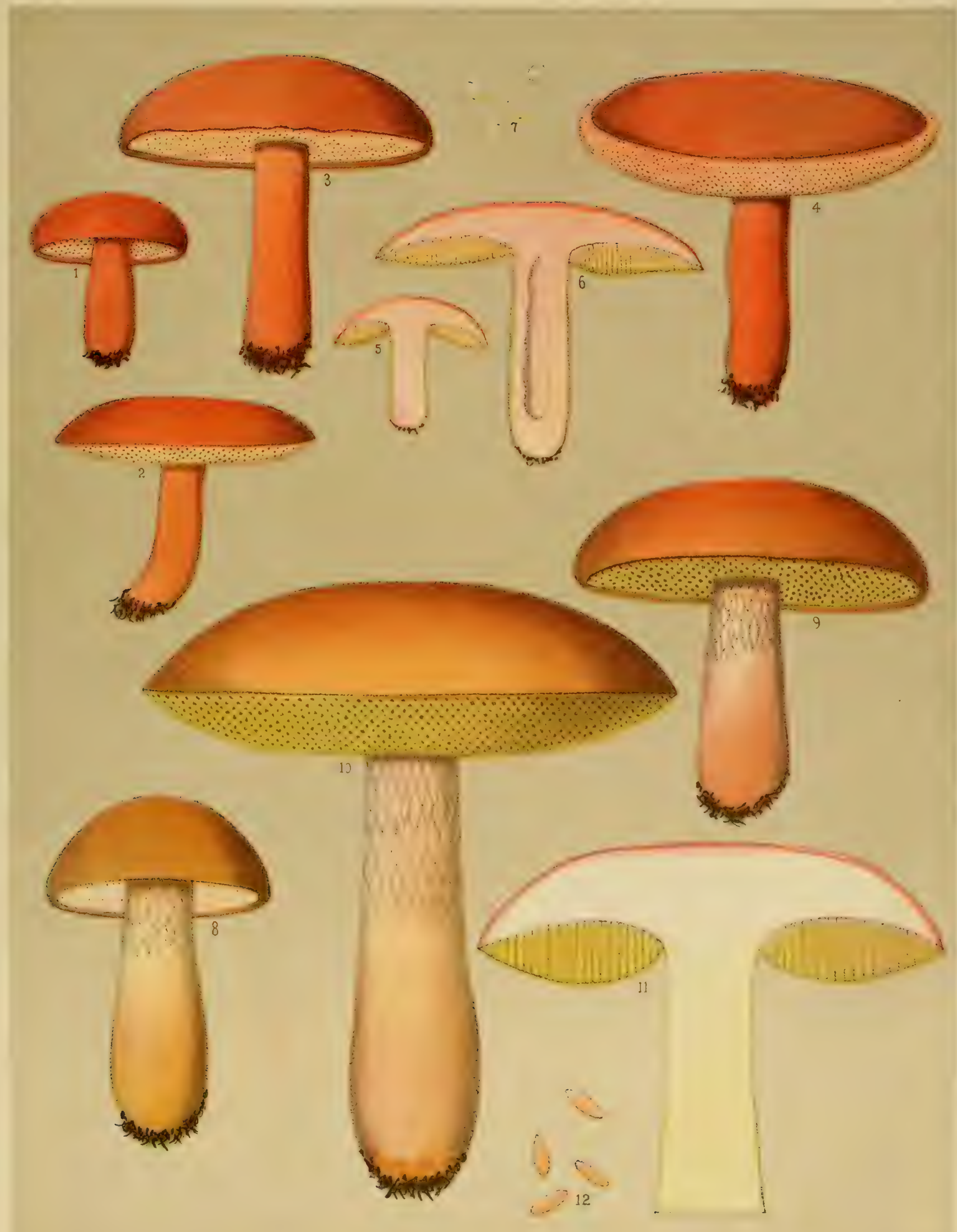





\section{EDIBLE FUNGI.}
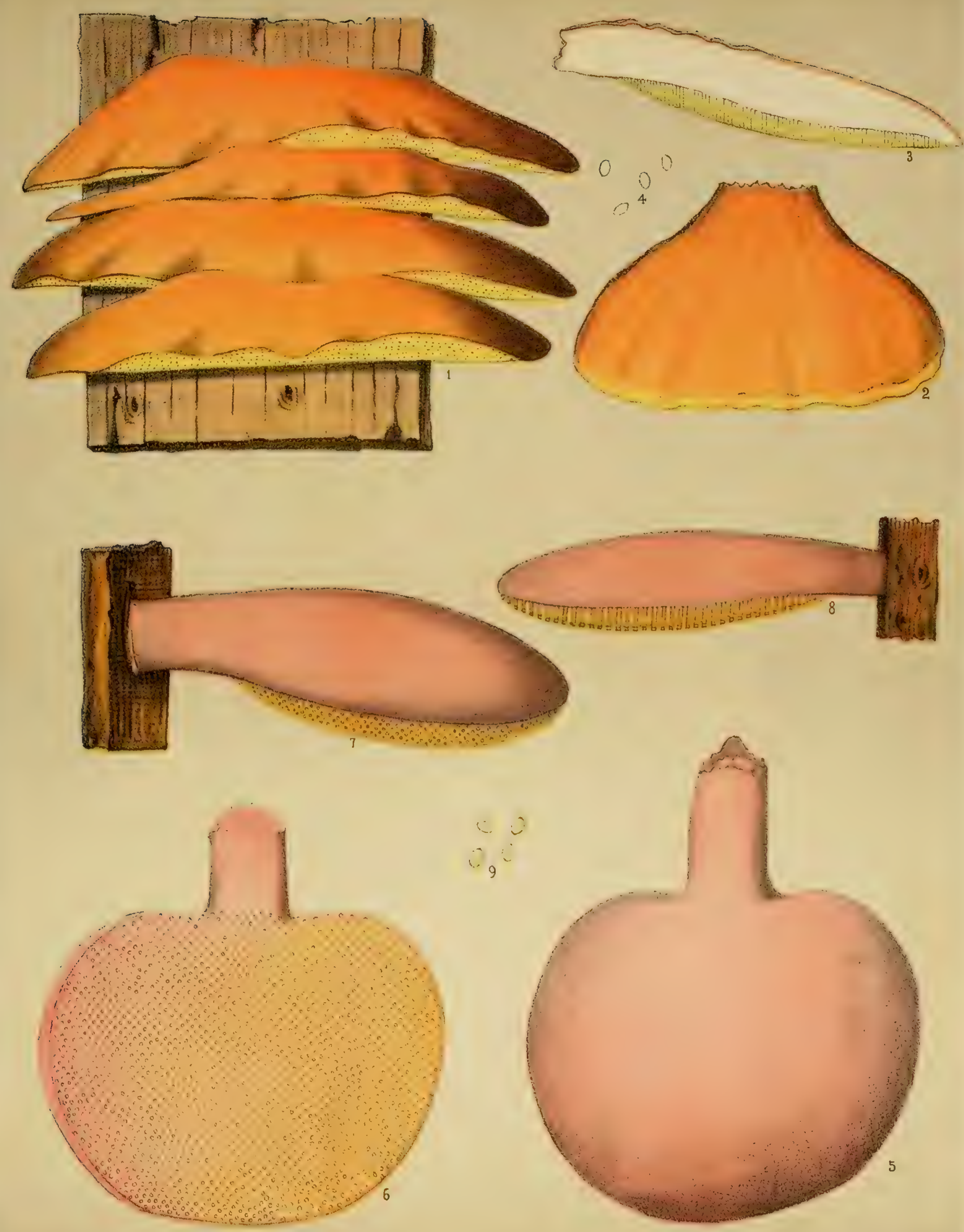



\section{EDIBLE FUNGI.}

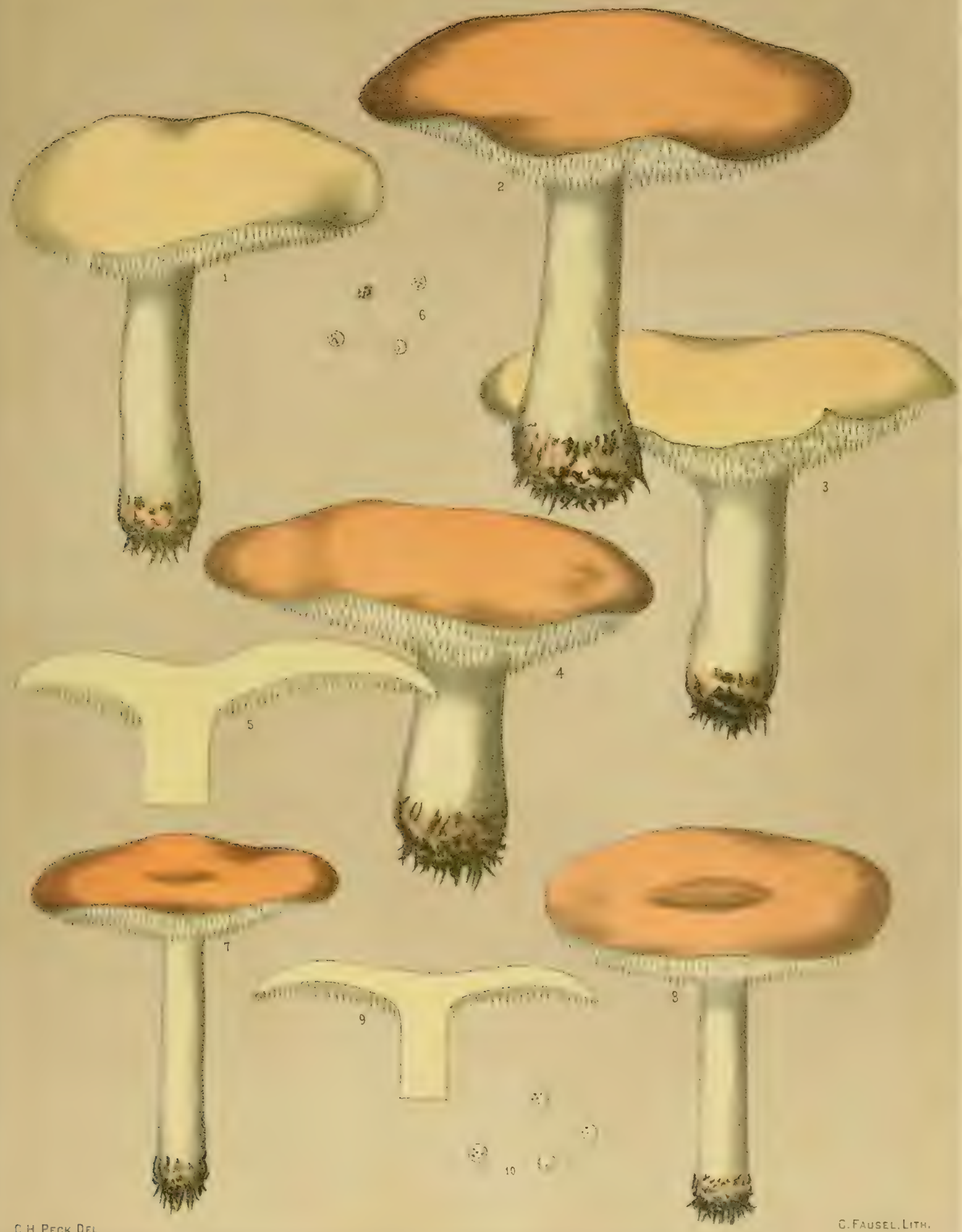

C H.PECK.DEL. 



\section{EDIBLE FUNGI.}

3)(17\% ain 240 1.

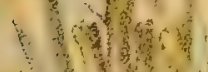

$\because$ :
(1) 1.

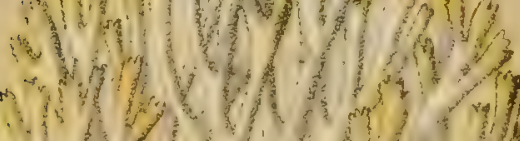
* W
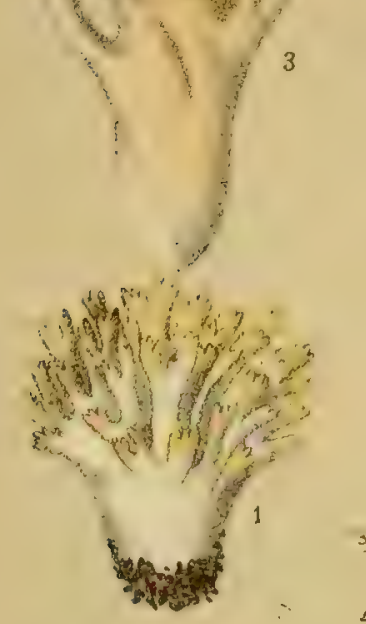

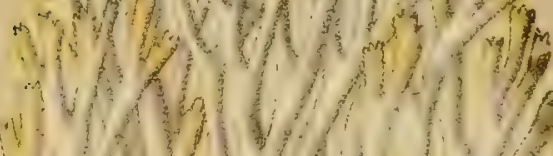

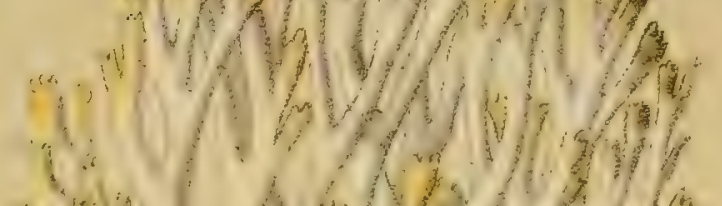

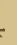

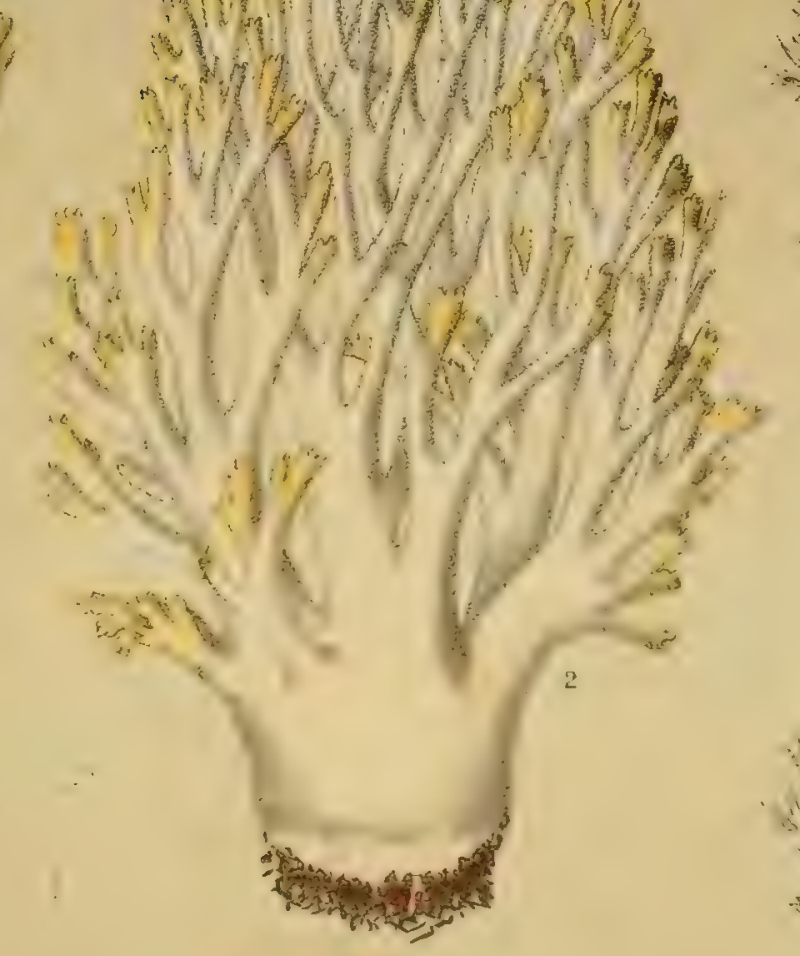

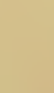

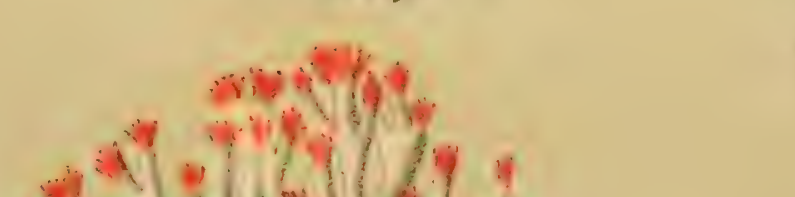

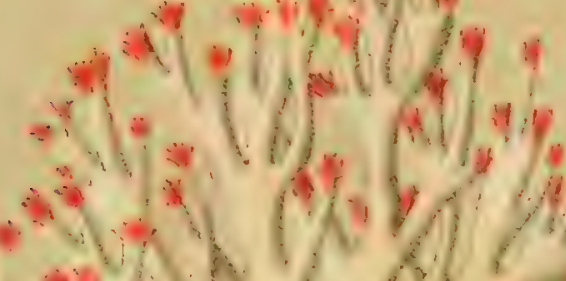

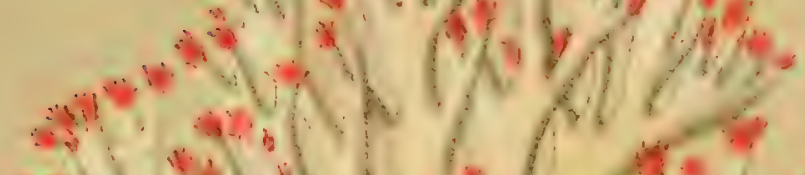

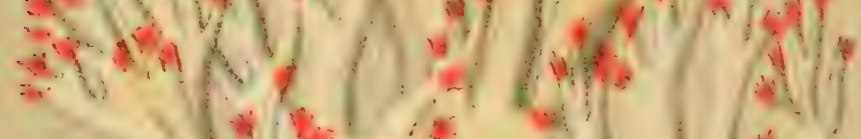

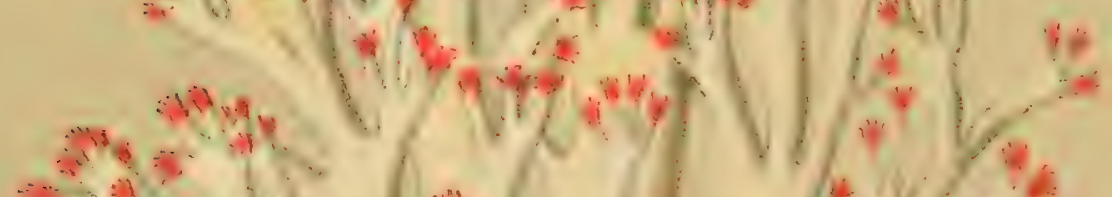
$\Rightarrow=4$

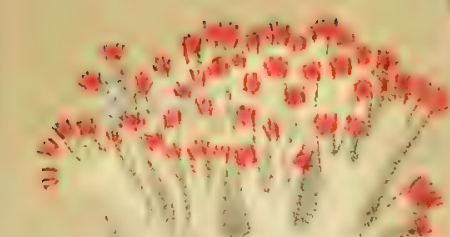
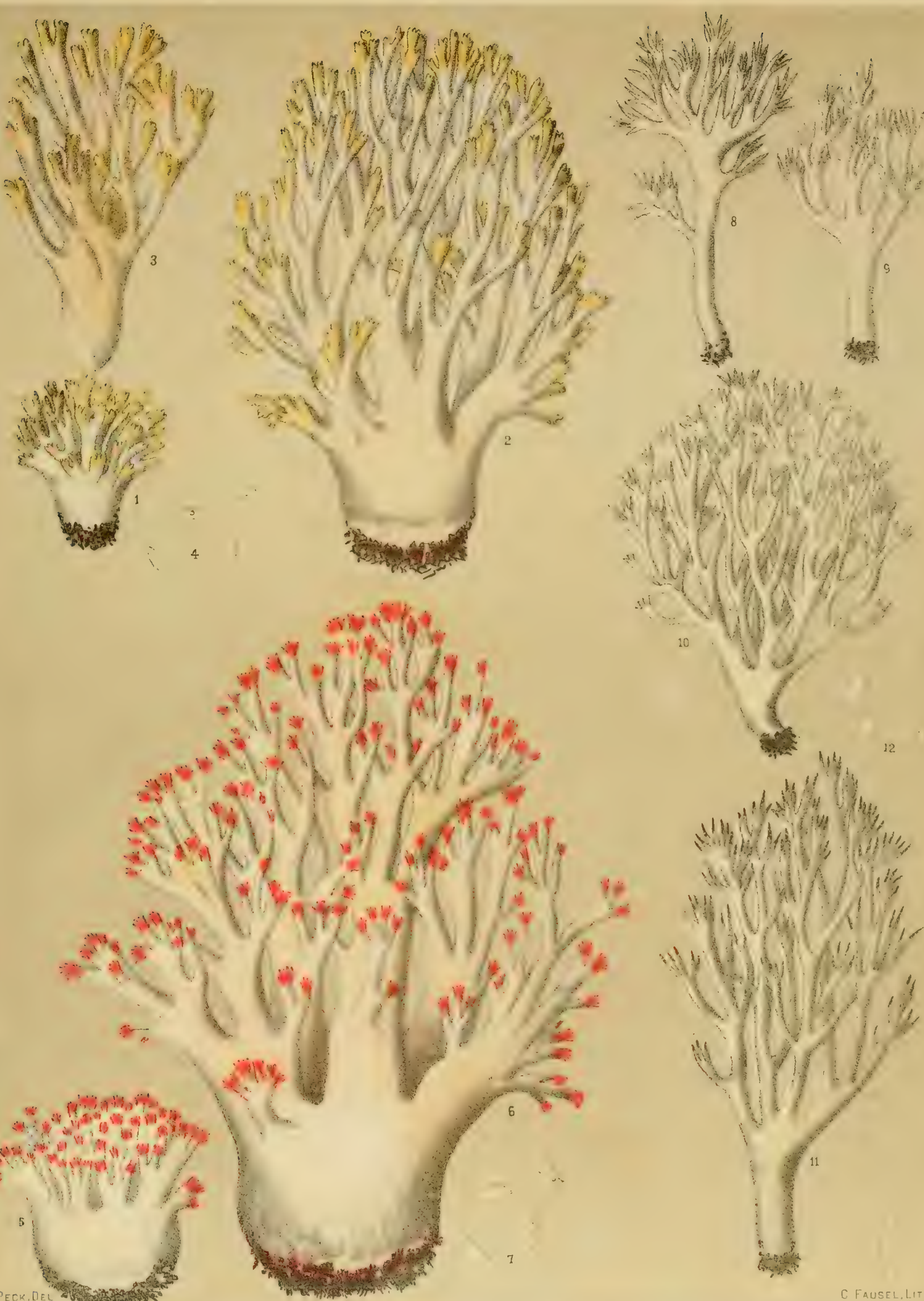

w. 1)
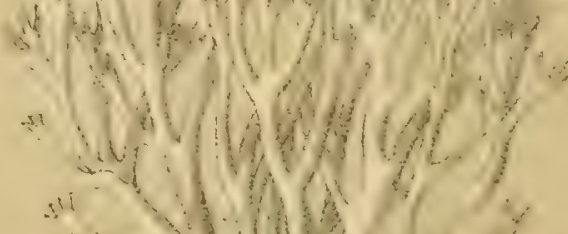

10

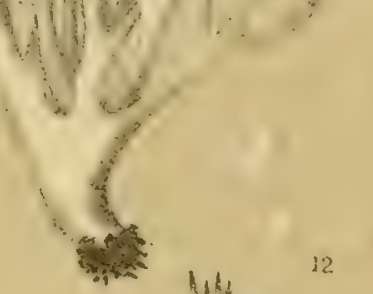

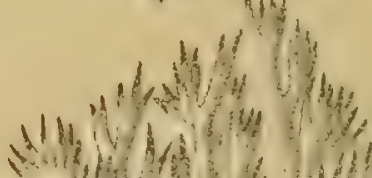

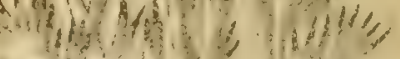
wo

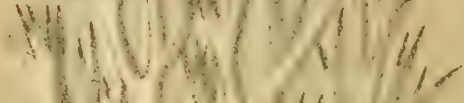

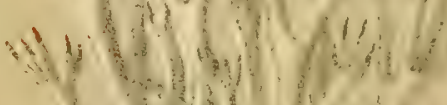

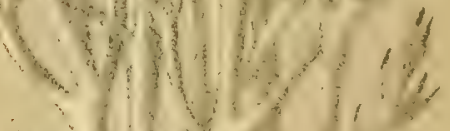

in

FIGS. 5 TO 7 CLAVARIA BOTRYTES PERS:

FIG8, T TO 4 CLAVARIA FLAVA SehaEFF. 



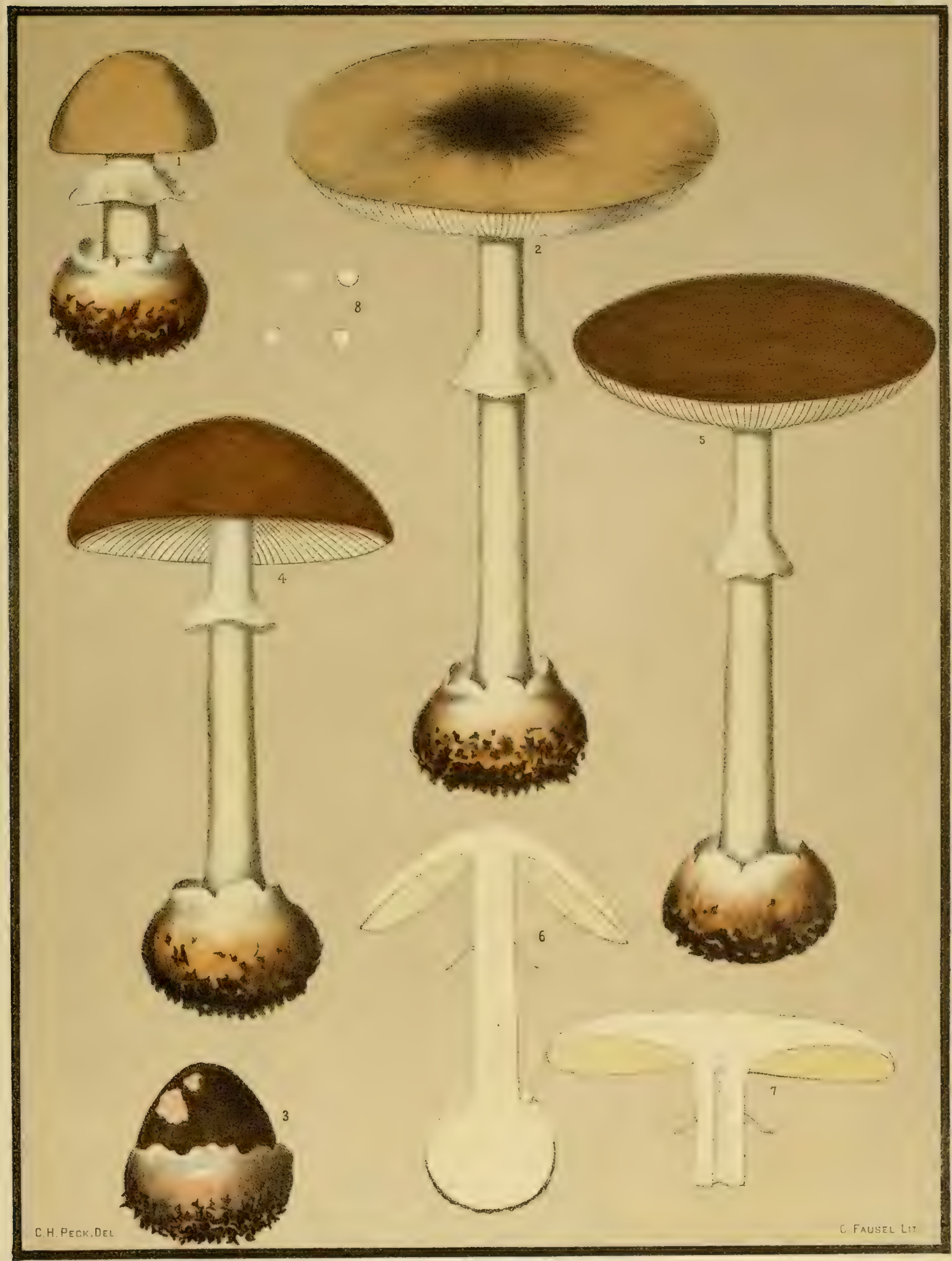





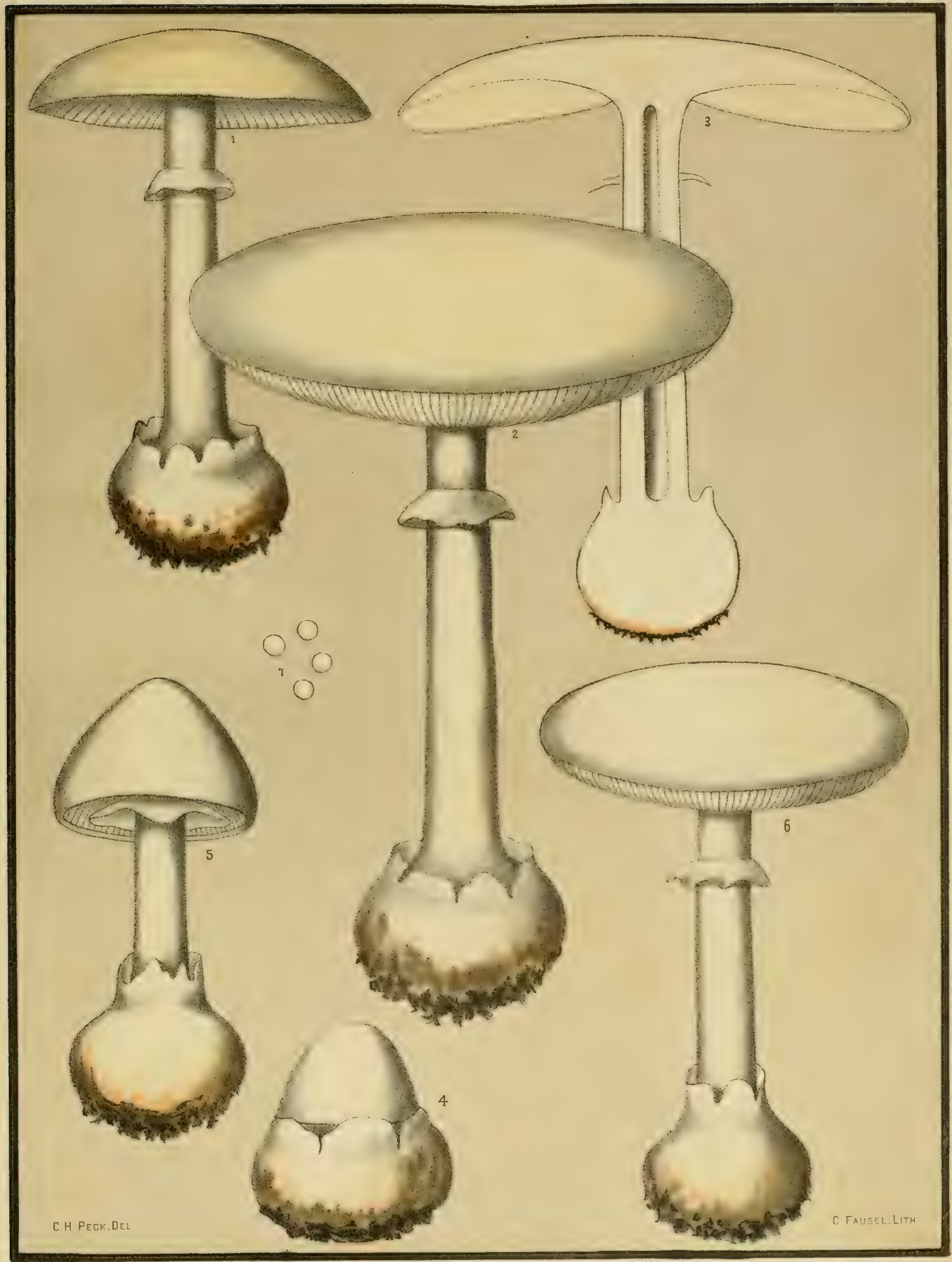





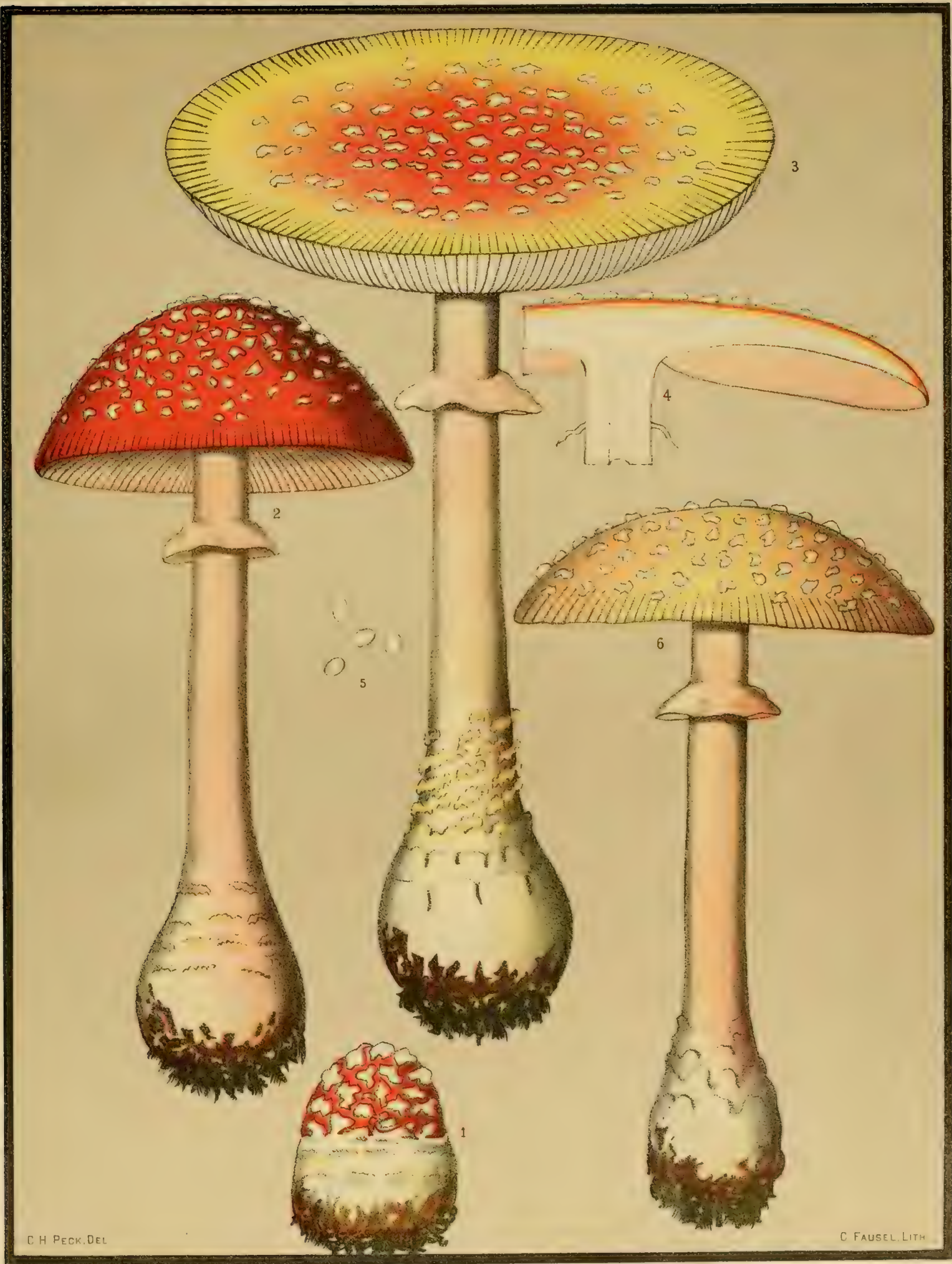





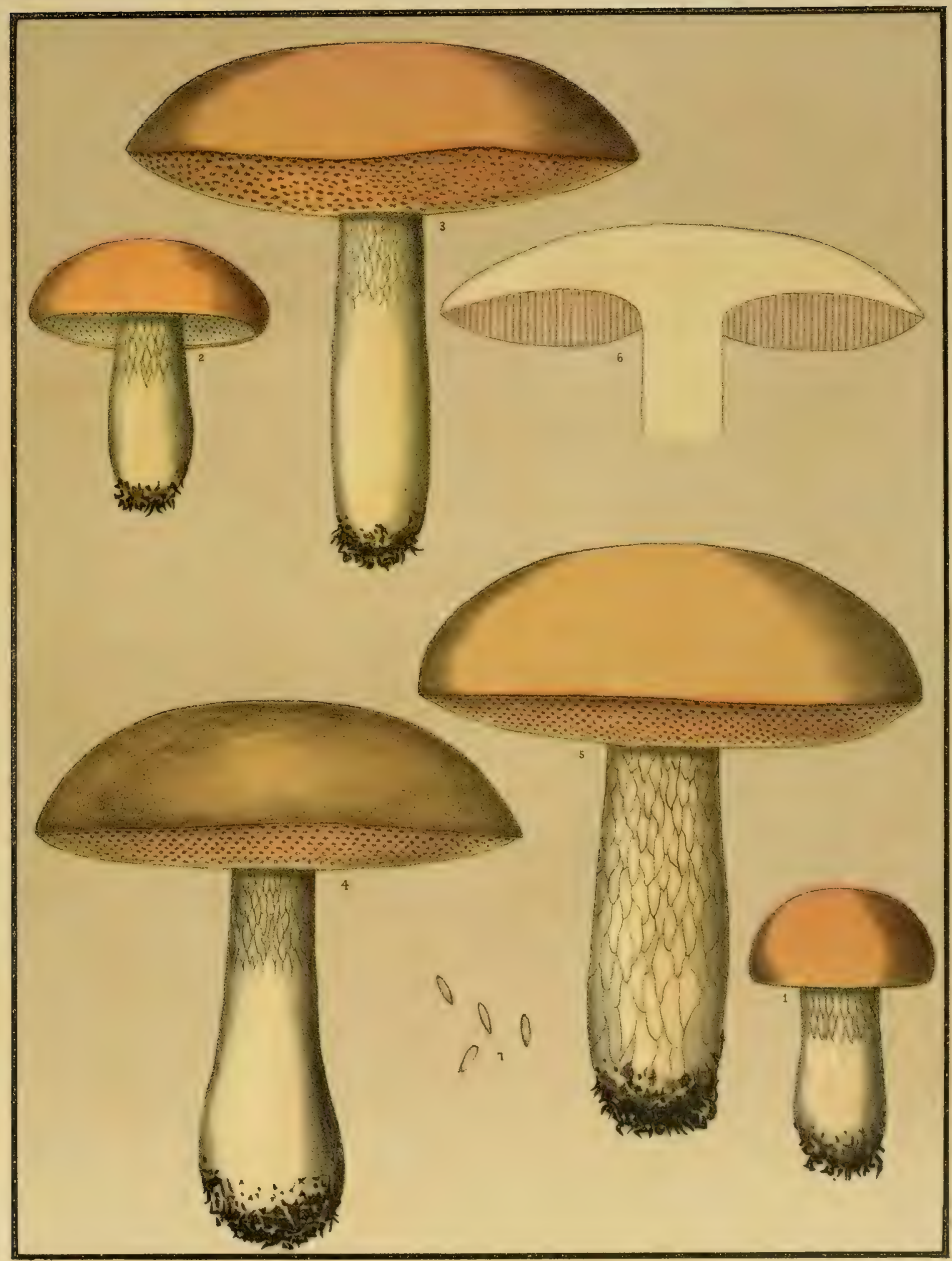





